\title{
THE EARLY QUATERNARY MARINE TO TERRESTRIAL TRANSITION OF THE SOUTHEASTERN WAIRARAPA, NEW ZEALAND
}

by

Sam Winiata Nowland

A thesis submitted to Victoria University of Wellington in partial fulfilment of the requirements of the degree of Master of Science with Honours in Geology

School of Geography, Environment and Earth Sciences

Victoria University of Wellington

October 2011 


\section{Frontispiece}

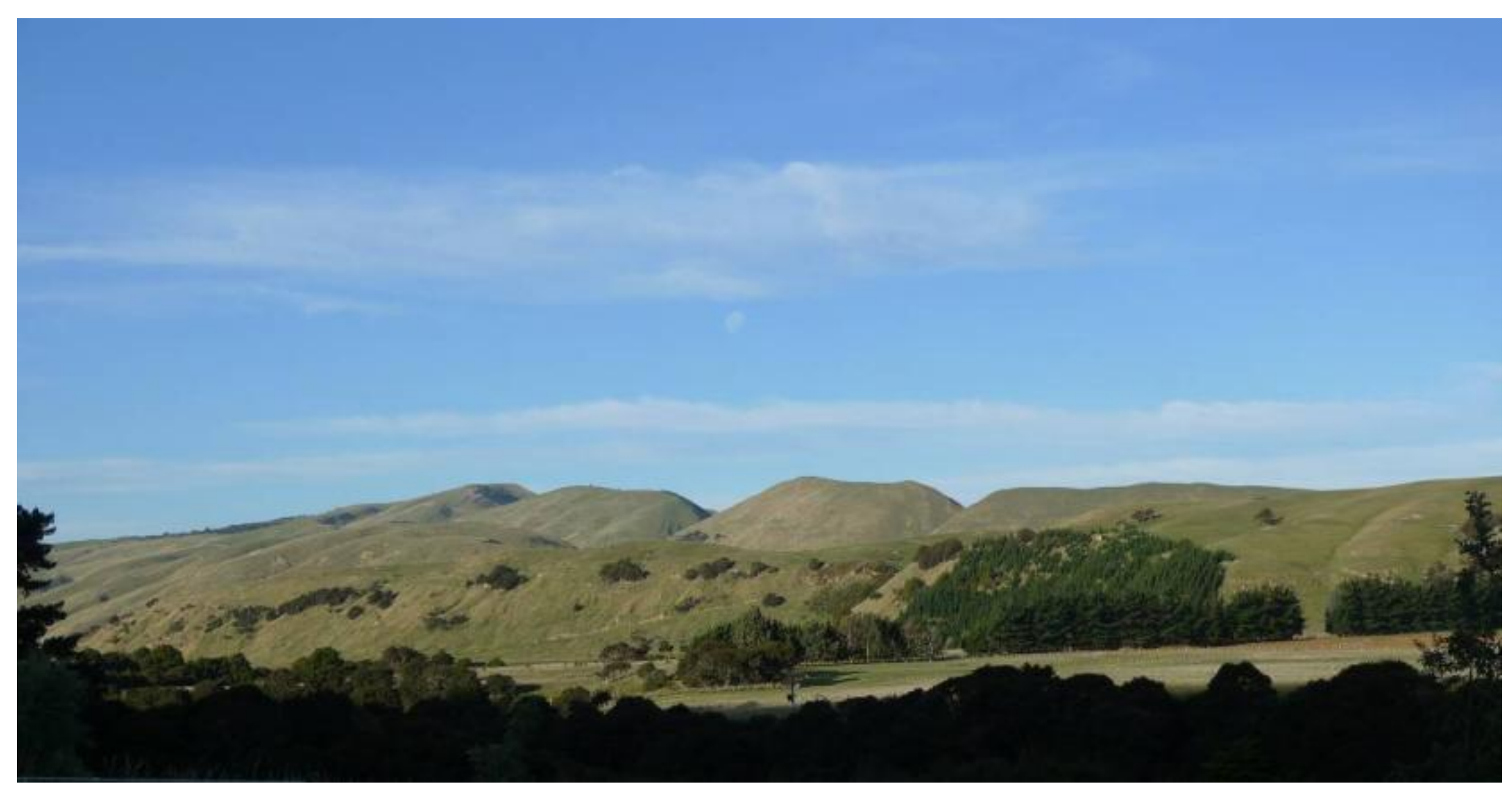

Nga Waka-o-Kupe, the Windy Peak Range, as viewed from Ruakokoputuna Road to the southwest. 


\begin{abstract}
This study examines the final emergence of the southeastern Wairarapa within a sequence stratigraphic framework. New exposures of the Pleistocene marginalmarine Hautotara Formation, and non-marine Te Muna Formation allow facies to be detailed and sequence architecture to be analysed.

Cyclicity observed within the facies successions of the Hautotara and Te Muna formations are placed in a series of four motifs. These motifs record $40 \mathrm{kyr}$ glacioeustatic cyclicity superimposed upon the basinward to landward progression of the environments, showing the region shallowing through time.

The positions of the top of the Pukenui Limestone and the base of the Hautotara Formation are revised, and are now at the top of the "Pukenui C" - a widespread marker bed, which also removes a historical nomenclatural gap. The recognition of the significance of the coccolith Gephyrocapsa sinuosa within the underlying Pukenui Limestone allows this contact to be dated at $1.73 \mathrm{Ma}$.
\end{abstract}

The 1.6 Ma age limit provided by a number of tephra within the lower sediments of the Te Muna Formation allow the ages of the examined formations to be constrained further. The eight $40 \mathrm{ka}$ cycles identified within the Hautotara Formation suggests deposition between 1.73 and $1.42 \mathrm{Ma}$.

The Hautotara - Te Muna Formation is revealed to be diachronous, with the base of the Te Muna Formation type section shown to be much younger, $1.12 \mathrm{Ma}$, than the $1.58 \mathrm{Ma}$ age of the lower contact observed elsewhere in the region. A series of palaeogeographic reconstructions at 1.73, 1.58 and 1.57 Ma demonstrate how closely related sedimentation patterns are to structural growth, with marginal-marine Hautotara Formation sedimentation persisting in the centre of the study area well after the initiation of Te Muna Formation terrestrial deposition to the north and south of this site. 


\section{Contents}

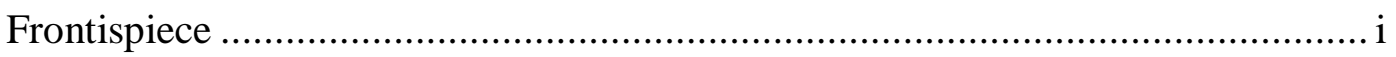

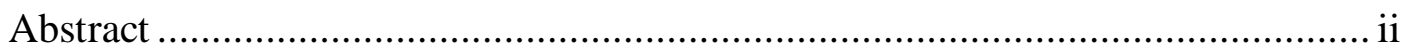

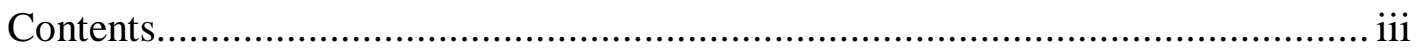

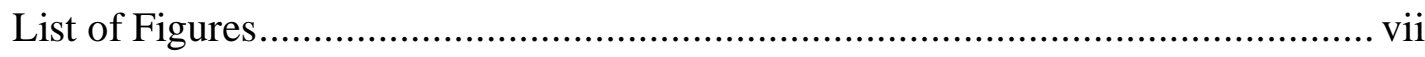

List of Tables .............................................................................................. vii

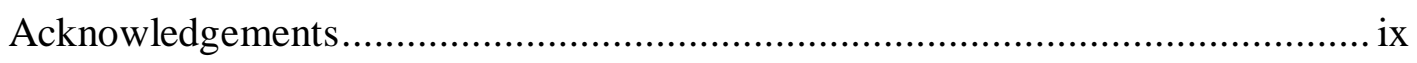

1 Chapter One Introduction ....................................................................... 1

1.1 Project Aims ............................................................................. 1

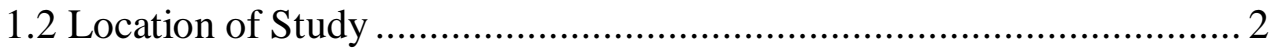

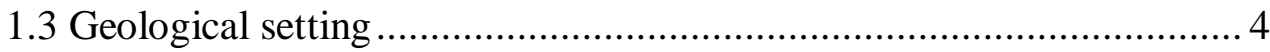

1.4 Previous work in the Study Area................................................. 6

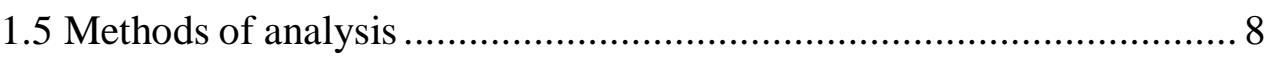

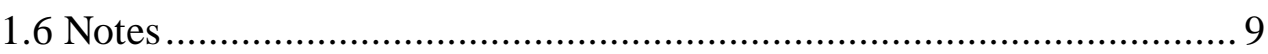

1.6.1 Map Series .............................................................. 9

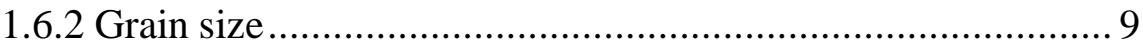

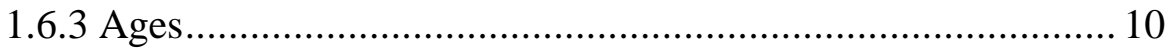

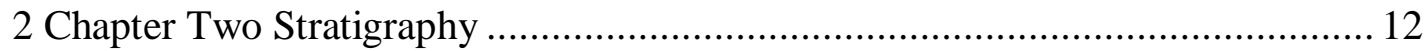

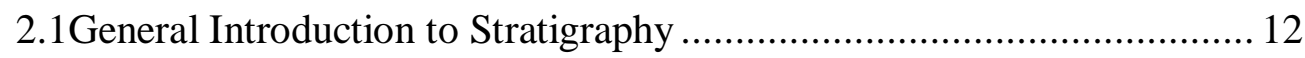

2.2 Pukenui Limestone ....................................................................... 15

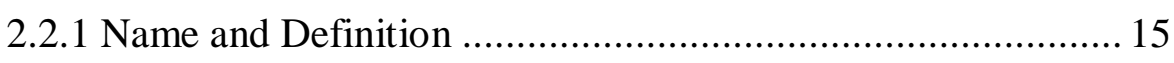

2.2.2 Type and Reference Section ........................................ 15

2.2.3 Lower Contact ................................................................. 16

2.2.4 Distribution and Thickness ................................................... 17

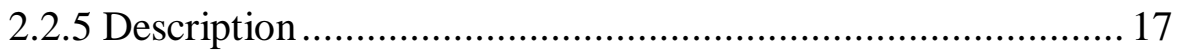

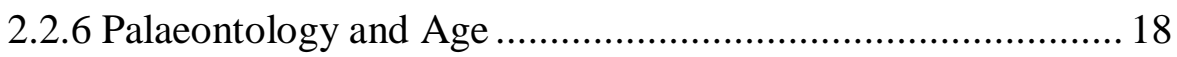

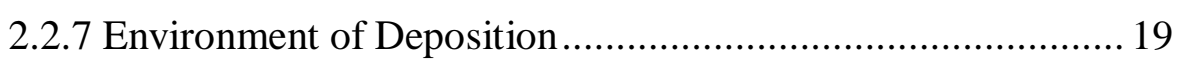

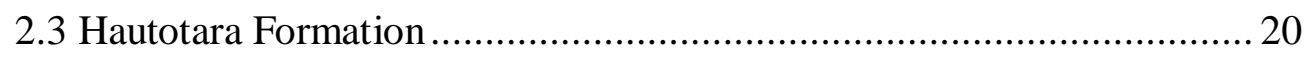

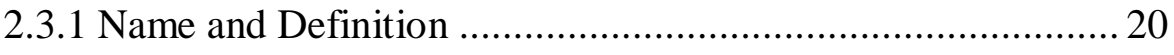

2.3.2 Type and Reference section ........................................... 20

2.3.3 Lower Contact .............................................................. 21 
2.3.4 Distribution and Thickness ............................................. 22

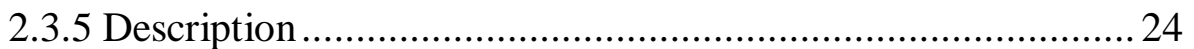

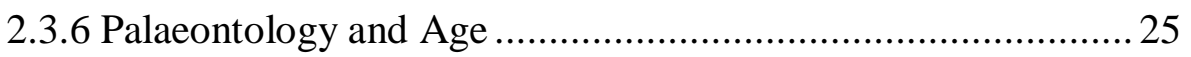

2.3.7 Environment of Deposition ........................................... 27

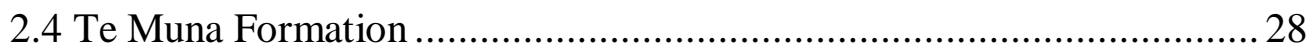

2.4.1 Name and Definition ................................................... 28

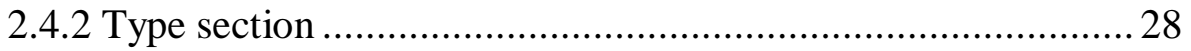

2.4.3 Lower Contact ................................................................. 28

2.4.4 Distribution and Thickness ................................................ 29

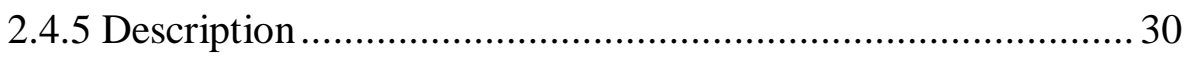

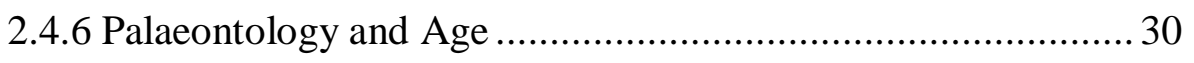

2.4.7 Environment of Deposition ........................................... 31

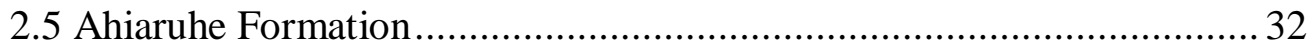

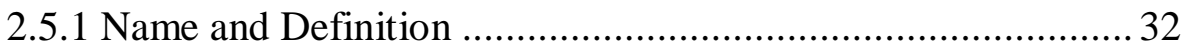

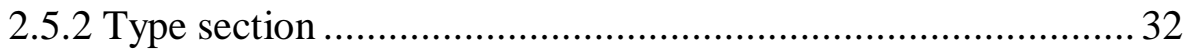

2.5.3 Lower Contact ..................................................................... 32

2.5.4 Distribution and Thickness ..................................................... 32

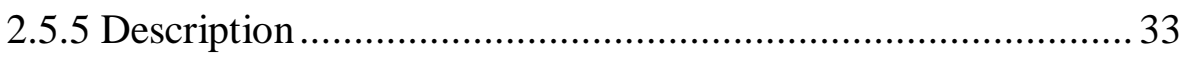

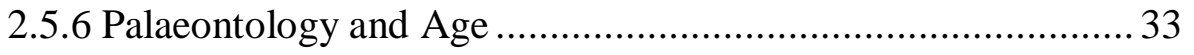

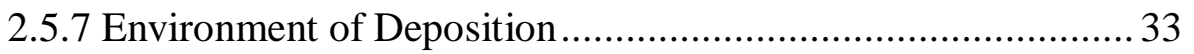

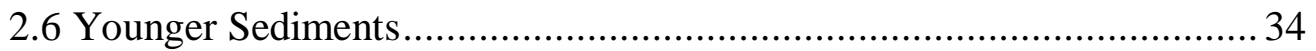

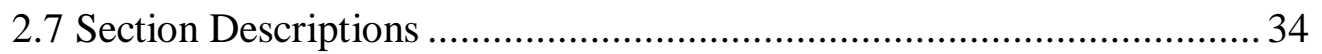

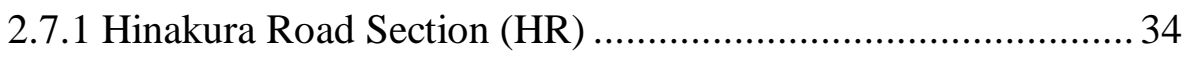

2.7.2 Huangarua West Section (HW) .......................................... 35

2.7.3 Ruawaka Section $(\mathrm{Rw})$.................................................. 35

2.7.4 Ruakokoputuna Bridge Cliff Section (Rk) ........................... 37

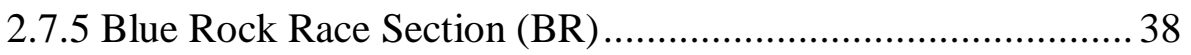

2.7.6 Blue Rock Hautotara Section $(\mathrm{BH})$.................................... 38

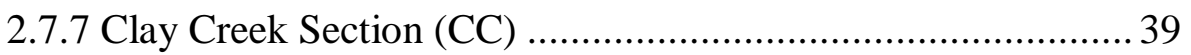

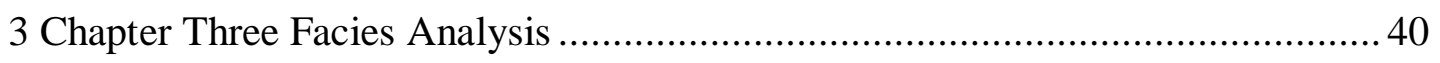

3.1 Introduction to the Facies Scheme.................................................. 41

3.2 Facies C - Conglomerates ......................................................... 42

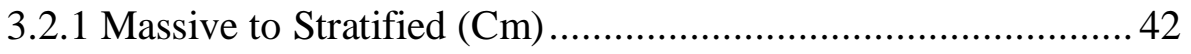

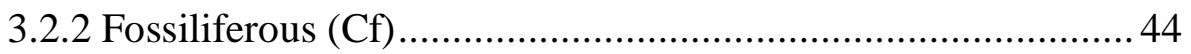


3.2.3 Stratified Gravel Conglomerate $(\mathrm{Cg})$ .45

3.2.4 Conglomerate - Shelly (Cs) ...........................................46

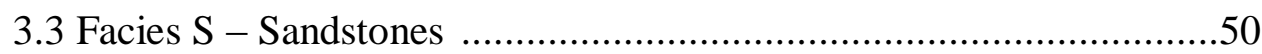

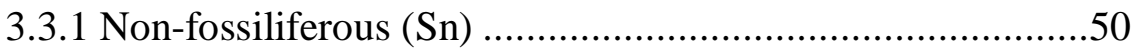

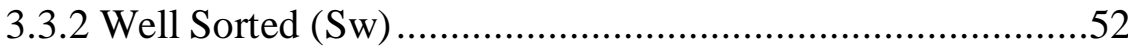

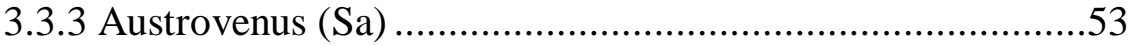

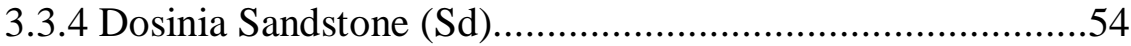

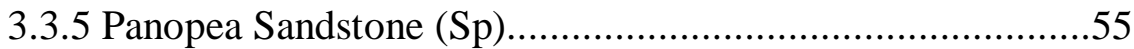

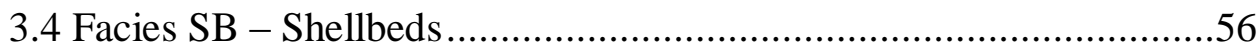

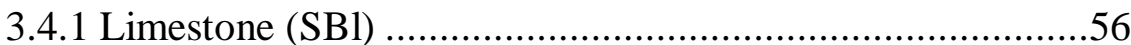

3.4.2 Zethalia Dominated Shellbed (SBz) ................................59

3.4.3 Tawera Dominated Shellbed (SBt) ................................60

3.4.4 Austrovenus-Limnoperna Dominated Shellbed (SBal) ........61

3.5 Facies M - Mudstones ..............................................................63

3.5.1 Sandy Mudstone (Ms) ..................................................63

3.5.2 Cross-Bedded Mudstone (Mc) ...........................................64

3.6 Facies V - Volcaniclastic...................................................66

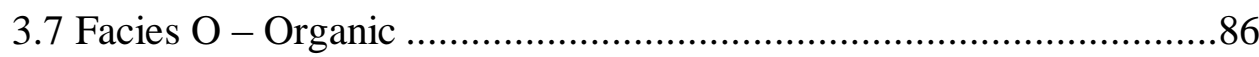

4 Chapter Four Stratigraphic Architecture and Cyclicity ..................................88

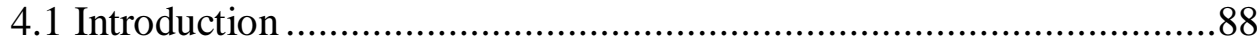

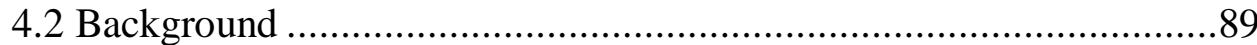

4.3 Systems Tracts and Surfaces .......................................................92

4.3.1 Lowstand system tract (LST): ..............................................92

4.3.2 Transgressive surface of erosion (TSE): ...................................92

4.3.3 Transgressive systems tract (TST): .......................................92

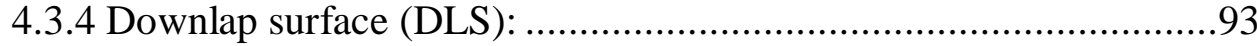

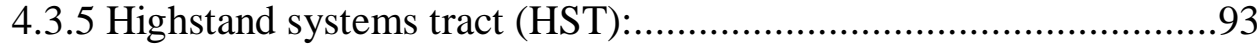

4.3.6 Regressive surface of erosion (RSE): ....................................93

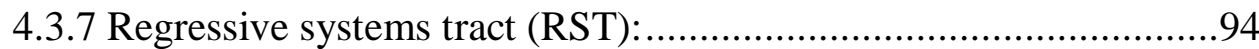

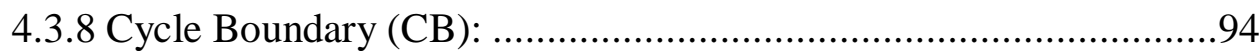

4.4 Stratigraphic Architecture of the Study Area .................................96

4.4.1 Motif One: Eringa Motif...................................................96

4.4.2 Motif Two: Huangarua Motif ...........................................98

4.4.3 Motif Three: Waipuna Motif..............................................99 
4.4.4 Motif Four: Te Muna Motif ................................................100

4.5 Architecture of Measured Sections..................................................101

4.5.1 Hinakura Road Section ...................................................101

4.5.2 Huangarua West Section.................................................101

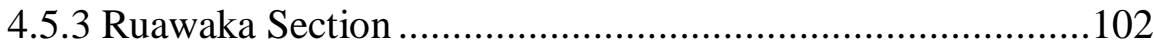

4.5.4 Ruakokoputuna Bridge Cliff Section ...............................103

4.5.5 Blue Rock Race Section ...................................................104

4.5.6 Blue Rock Hautotara Section ............................................104

4.5.7 Clay Creek Section ...........................................................105

5 Chapter Five Synthesis and Palaeogeography..........................................107

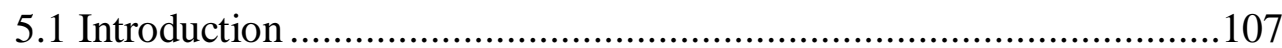

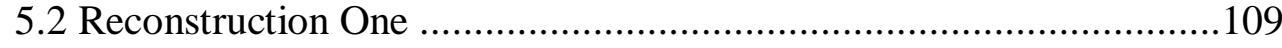

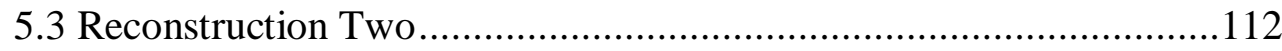

5.4 Reconstruction Three ..............................................................115

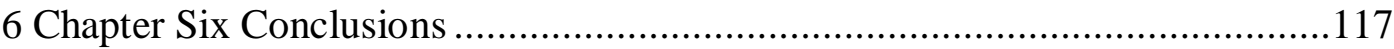

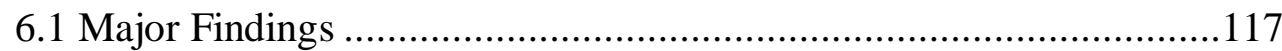

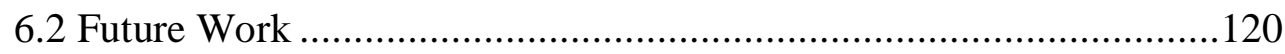

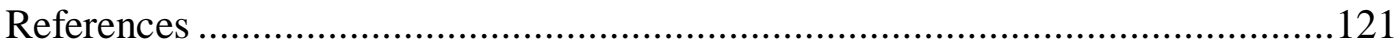

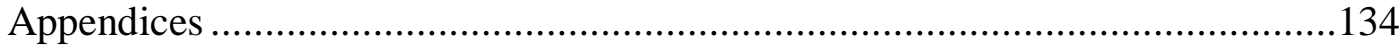

Appendix One Geological Map 1

Appendix Two Stratigraphic Columns 2

Appendix Three Grain size 3

Appendix Four Tephra Analysis 4

Appendix Five Location Conversion $\quad 6$

$\begin{array}{ll}\text { Appendix Six Macrofossil Identification } & 7\end{array}$ 


\section{List of Figures}

Figure 1.1 Location of the study area and New Zealand tectonic setting. 3

Figure 1.2 East Coast Forearc Basins. 5

$\begin{array}{ll}\text { Figure 1.3Locations of Maps used in this thesis. } & 10\end{array}$

Figure 1.4 New Zealand Pliocene-Holocene time-scale. 11

Figure.2.1 Previous authors naming of Eastern Wairarapa Valley stratigraphy and $\begin{array}{ll}\text { that used in this study. } & 13\end{array}$

$\begin{array}{ll}\text { Figure.2.2 Location of Type Sections } & 14\end{array}$

Figure 2.3 Transition from Greycliffs Formation to the Pukenui Limestone. 16

Figure 2.4 Contact between Pukenui Limestone and Hautotara Formation 23

Figure 2.5 Gammate structures in the Te Muna Formation 30

Figure 2.6 Collage of Measured Sections 36

Figure 3.1 The wave base setting of an open coast shelf to shoreface profile 41

Figure 3.2 Collage of facies 43

Figure 3.3 Collage of facies $\quad 49$

Figure 3.4 Grain size distribution and sorting between the sandstone facies 51

Figure 3.5 Collage of facies $\quad 58$

Figure 3.6 Collage of facies $\quad 62$

Figure 3.7 Location of tephra in study area 67

Figure 3.8 Hinakura Road Lower Tephra major element plots 69

$\begin{array}{ll}\text { Figure 3.9 Collage of tephra } & 70\end{array}$

Figure 3.10 Hinakura Road Upper Tephra major element plots 71

Figure 3.11 Hinakura Road Tephra and regional correlatives 73

Figure 3.12 Hinakura Road Area tephra and correlatives 74

Figure 3.13 Collage of tephra and organics 76

Figure 3.14 Huangarua-lower Tephra major element plots 77

Figure 3.15 Huangarua-lower Tephra and correlatives 78

Figure 3.16 Huangarua-upper Tephra major element plots 79

Figure 3.17 Lower Te Muna Tephra and correlatives 82

Figure 3.18 Upper Te Muna Tephra major element plots 84

Figure 3.19 Upper Te Muna Tephra and correlatives 85 
Figure 4.1 Interpreted Sea-Level changes through time 90

Figure 4.2 Relative position of systems tracts and shellbeds. 91

Figure 4.3 Idealised Motifs of the Study Area 97

$\begin{array}{ll}\text { Figure 4.4 Rampton (1997) reinterpretation } & 102\end{array}$

$\begin{array}{ll}\text { Figure 4.5 Fence Diagram of Measured Sections } & 106\end{array}$

$\begin{array}{ll}\text { Figure 5.1 Structural setting of the study area. } & 108\end{array}$

$\begin{array}{ll}\text { Figure 5.2 Palaeogeographic reconstruction at } \sim 1.73 \mathrm{Ma} & 110\end{array}$

Figure 5.3 "Pukenui C" within the Whangaehu Valley, north of the study area 111

Figure 5.4 Palaeogeographic reconstruction of $\sim 1.58 \mathrm{Ma}$. 113

Figure 5.5 Palaeogeographic reconstruction of $\sim 1.57 \mathrm{Ma}$. 116

\section{List of Tables}

Table 3.1 Common fossils of conglomerate facies of the study area 48

Table 3.2 Tephra of the Hautotara and Te Muna formations in this study 66

Table 3.3 Hinakura Road tephra and correlatives $\quad 68$

Table 3.4 Huangarua-lower Tephra and correlatives 75

Table 3.5 Huangarua- Upper Tephra and correlatives 79

Table 3.6 Lower Te Muna Tephra and correlatives 81

Table 3.7 Upper Te Muna Tephra and correlatives 83

$\begin{array}{ll}\text { Table 3.8 Facies Summary } & 87\end{array}$ 


\section{Acknowledgements}

This could easily stretch on for many pages, so in the interests of brevity detailed thanks will have to be extended to each and every one of these people in person. Firstly, thanks go to my awesome supervisors Dr. Cliff Atkins and Assoc. Prof. Mike Hannah who have always been enthusiastic yet calming, knowledgeable, and also very, very patient.

To Brent Alloway, Peter Barrett, Alan Beu, Kyle Bland, Dene Carroll, John Collen, James Crampton, Gav Dunbar, Stephen Eager, Tim Little, Richard Levy, Tim Naish, and Gigi Woods, thank you so much for your assistance with (and stimulating discussions of) various aspects of my project, including fossil identification, sequence stratigraphy and laboratory work. I am also greatly indebted to Aidan Allan, the BVA, John Creech, Marc-Alban Millet, Matt Stevens and Ramona White who have provided much time and help with the work on the tephra analysis. Fellow members of Co305 (the Danger Zone), George/Me Mett/MFR, Katie, Moon, The Bod and Skinner - it has been an experience.

Thank you to all the people that have under duress assisted me with fieldwork, many of which are listed above, but also include Kate Coles, Sarah Grain, Rach Carne, Dave Murphy, Caro Hall, Jodi, Simon, Elaine, Pras, Chris and Tim. These thanks are also extended to my classmates, demonstrators, and the students of the various classes and the Te Muna Fieldtrips I have been associated with over the last few years. Kate Coles, thank you for all your wonderful support, and also for all the editing and appendix work.

Thanks to Liz Richardson and Te Rōpū Āwhina, this project was assisted by a Te Tipu Pūtaiao scholarship from FRST, agreement \# VUWX0602. Also, thank you to the farmers of the area, and in particular Arthur and Felicity Warren of Ruawaka for the accommodation, humour, and duck.

Lastly, I am especially grateful for the support of my family; especially Mum, many of your ideas were interesting and not quite correct, but always noted. 


\section{Chapter One \\ Introduction}

\subsection{Project Aims}

This thesis focuses on two Pleistocene sedimentary formations cropping out in the streams and hills east of the lower Wairarapa Valley, in the southern North Island, New Zealand. The Hautotara Formation is an early Pleistocene marginal marine succession representing the final emergence of the Eastern Wairarapa Valley. It exhibits significant lateral variation, is comprised of many different facies, and contains numerous erosional surfaces. The Te Muna Formation is a middle Pleistocene alternating succession of fluvial conglomerates and lacustrine mudstone, and represents the response of a fully terrestrial Wairarapa Valley to changes in sealevel (Collen \& Vella, 1984).

The timing of events and units recorded by the formations have previously not been well constrained. This study advances the understanding of the Hautotara and Te Muna Formations, by utilising detailed measured sections, new tephrochronological and biostratigraphic data to provide improved sequence stratigraphic resolution and ultimately an improved geological interpretation of the area.

\section{Aim One: \\ Produce revised ages for the Hautotara and Te Muna Formations.}

Cyclicity present in the Late Miocene to Pleistocene sedimentary deposits of the Eastern Wairarapa Valley has been examined in an attempt to document the pattern of glacio-eustatic sea-level changes in the basin (Gammon, 1995, 1997; Vella, 1963a). With advances in the understanding of the sequence stratigraphic framework, subtle changes in the sedimentary deposits, macrofossil assemblages and boundary conditions of the Hautotara Formation will be used to identify Milankovitch-scale variations of sea-level change in increased detail. 


\section{Aim Two: \\ Identify sequence stratigraphic motifs of the Hautotara and Te Muna Formations.}

The study area is located in a fold and thrust belt of the active Hikurangi subduction margin (Figure 1.1A). The timing and rates of growth of the main structural features of the study area can be identified using a well-constrained chronology of the stratigraphic succession (Nicol et al., 2002). By combining the tectonic, biostratigraphic, sedimentary and sequence-stratigraphic data, a palaeogeographic reconstruction of the Eastern Wairarapa Valley over the Quaternary is produced.

\section{Aim Three: \\ Present the Early Quaternary marine to terrestrial transition of the Eastern Wairarapa Valley, through palaeogeographical reconstructions.}

Improved resolution within the Pleistocene marginal marine and terrestrial deposits of the Eastern Wairarapa Valley allows a palaeogeographic reconstruction of the region to be undertaken. A number of palaeogeographic maps presented here allow increased understanding of the timing and spatial evolution of the varying sedimentary sequences within the study area. These may be compared to sedimentary deposits over the corresponding time in the Wanganui and Hawke's Bay Basins (e.g. Erdman \& Kelsey, 1992; Pillans et al., 2005; Bland, 2006) to further define the timing of events over the lower North Island.

\subsection{Location of Study}

The study area is a seventeen kilometre long, southwest to northeast aligned region located approximately ten kilometres south of Martinborough in the southeastern Wairarapa (Figure 1.1B). This area extends from the Ruakokoputuna River Valley, 800 metres southwest of the confluence with Clay Creek, to Hinakura Road in the north, incorporating the Huangarua River and the lower portion of the Blue Rock Stream Valley (Appendix One - Geological Map). 

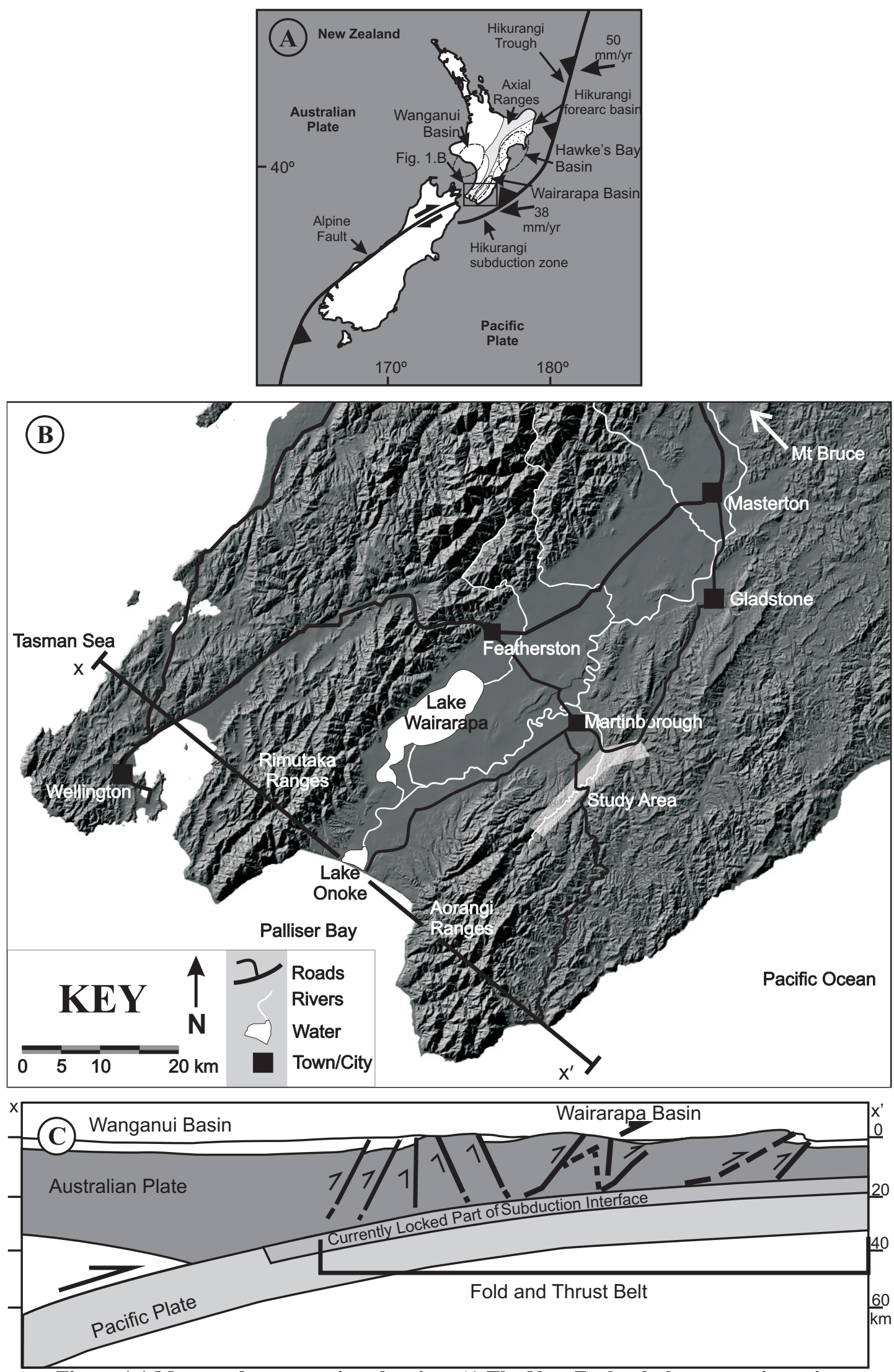

Figure 1.1 Maps and cross section showing: A) The New Zealand plate tectonic setting

(modified from Little et al., 2009); B) the location of the study area within the lower North

Island, and C) simplified subduction interface of the lower North Island (modified from Little et al., 2009 after Wallace et al., 2005). 
Outcrops are largely restricted to recent river or road cuttings, although useable exposures are also found within the many streams draining westwards off the Windy Peak Range (Nga Waka-a-Kupe).

\subsection{Geological setting}

The study area is located on the eastern margin of the Wairarapa Valley, the southern portion of the emergent Hikurangi forearc basin (Nicol et al., 2002). The Hikurangi forearc basin is a result of the oblique convergence of the Pacific and Australian plates to the east of the North Island, where the Pacific plate is actively being subducted (Figure 1.1C). The deformation within the Hikurangi Margin plate boundary zone has resulted in a series of strike-slip faults within the axial ranges to the west of the Wairarapa Valley, and a fold and thrust belt that extends to the east of the study area (Figure 1.1C).

Over the last $10 \mathrm{Myr}$, as a result of the plate convergence, the Hikurangi forearc basin has been differentially uplifting (Beanland et al., 1998; Nicol et al., 2002), resulting in the deposition of progressively shallower marine deposits, and in the Mid to Late Pleistocene, terrestrial formations. Basement greywackes and argillites (herein called as greywacke) of Mesozoic age outcrop as physical highs in many areas bounding the Wairarapa Valley, in particular the Aorangi and Rimutaka ranges (Figure 1.1B). Prior to circa $2 \mathrm{Ma}$, a strongly tidally-influenced palaeoseaway stretched through the forearc basin. This $300 \mathrm{~km}$ long, relatively narrow (30-60 km) northeast to southwest trending feature, the Ruataniwha Strait (Beu, 1995), extended from the Cook Strait at the southern end of the Wairarapa Valley through to Gisborne in the north (Nelson et al., 2000). Around 2 Ma, a greywacke high known as the Mt Bruce block, located in the Northern Wairarapa, was uplifted and closed the north-south flow of the Ruataniwha Strait, separating the Hawke's Bay and Wairarapa Basins, the major Quaternary depocentres of the East Coast (Figure 1.1A) (Beu, 1995). 


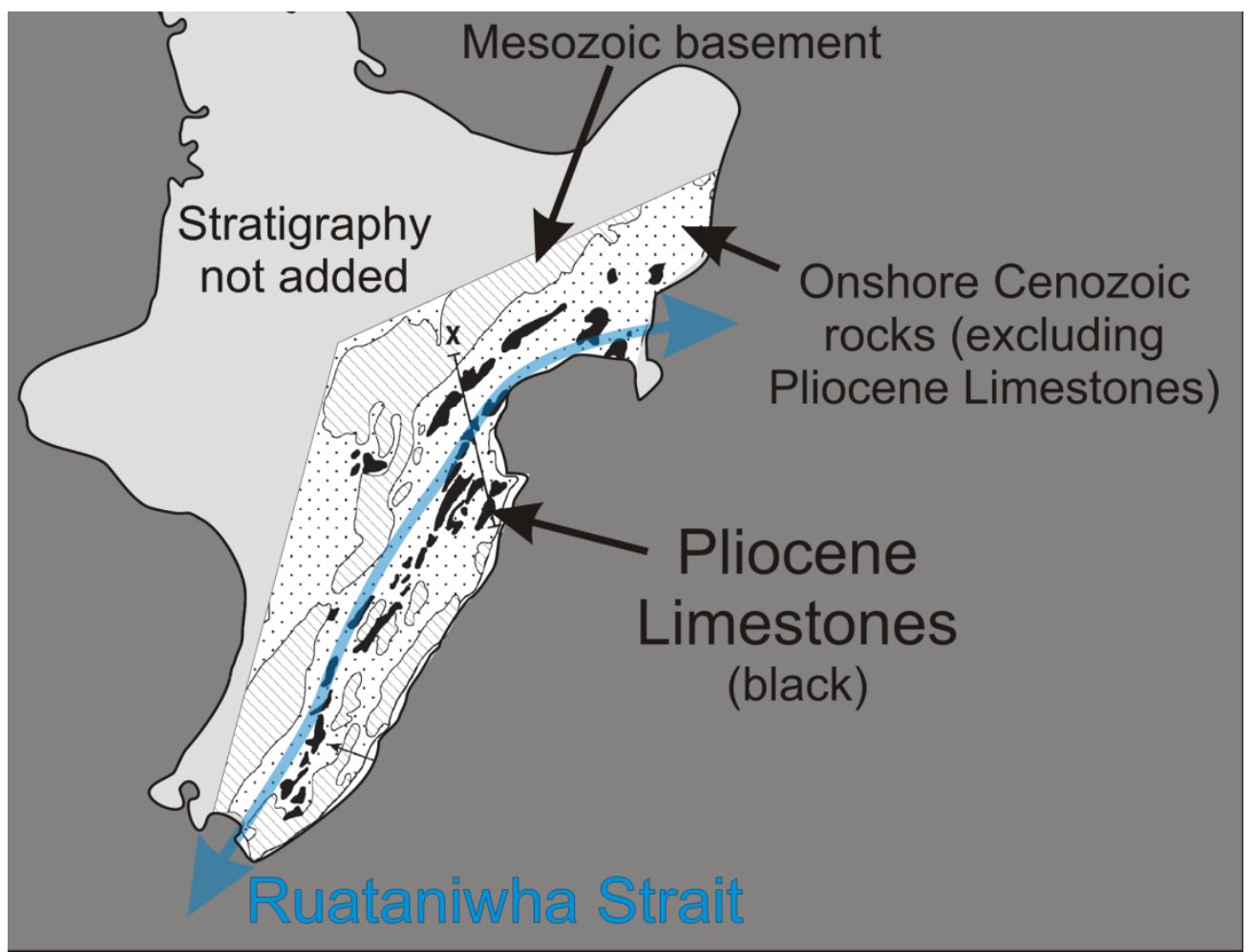

Figure 1.2 East Coast Forearc Basins setting showing location of Ruataniwha Strait, basement rocks and Pliocene Limestones (Modified from Nelson et al., 2003).

The irregular uplift of the forearc basin has resulted in a variation of the depositional settings of the basins, including tidal current-dominated regions and large marine embayments (Beu, 1995). This evolution of the forearc basin culminated in the deposition of Plio-Pleistocene limestones and marginal marine deposits (Lee \& Begg, 2002; Caron et al., 2004), which are in turn overlain by the extensive terrestrial deposits of the emergent valleys. Within the Wairarapa Basin, these deposits include the Pleistocene Pukenui Limestone and Hautotara Formations, with the overlying terrestrial Te Muna and Ahiaruhe Formations (Begg \& Johnston, 2000).

The main structural fabric of the Wairarapa Basin trends northeast/southwest, and within the study area there are several named and unnamed structural features related to this, including the Huangarua Fault, Huangarua Syncline, Windy Peak Anticline and Monocline, and the Ruakokoputuna Syncline (Appendix One - Geological Map). These contractional features have played an active role in controlling the spatial and temporal distribution of sediment deposition in the study area through the Plio-Pleistocene. 


\subsection{Previous work in the Study Area}

The study area has a long history of geological study, dating back to Crawford (1871), who identified "Fossiliferous Limestone" and "Fine Red Gravels" in the Hautotara region, and McKay $(1878,1879)$ who noted "Rotella zelandica" [Zethalia zelandica] in reddish-brown sands and gravels, and the (still common) difficulty of attempting to remove fossils from the near vertical beds next to the Hautotara [Huangarua] River.

Following these preliminary observations were several studies identifying and describing the fossil assemblage of the area, including Thomson (1919), Waghorn (1927) and King (1933). Waghorn (1927) also discussed the fault bounding of the upper Ruakokoputuna Valley.

Beginning in the late 1940's, Victoria University of Wellington (VUW) students began actively studying within the region, with Couper (1948) mapping an area that included the southern part of this study area, and Vella (1949, 1963a) identifying three cyclothems within strata to the north of the present study area. Rodley (1961) gave informal names to the succession of limestones and marginal marine beds in the Makara/Huangarua River area, and these can still be identified today, although commonly used in a slightly different manner (Chapter Two). Her descriptions of the marginal marine units form the basis of the Hautotara Formation type section (Collen \& Vella, 1984). Bates (1967) mapped an extensive area that encompassed Palliser Bay, the western side of the Aorangi Ranges and the Ruakokoputuna and Blue Rock Valleys, correlating late Cenezoic sediments within an area exceeding 350 square kilometres.

Paul Vella's numerous studies of the Wairarapa Valley include lithostratigraphic investigations and initial cyclothem studies of the rocks east of Martinborough (e.g., Vella, 1963a; Vella \& Briggs, 1971). The modern definitions of the Hautotara, Te Muna and Ahiaruhe Formations were presented in a paper by Collen \& Vella (1984). A preliminary structural history of the region was published by Lamb \& Vella (1987), although it is accepted that the age used for the Te Muna Formation was 
incorrect, and a key outcrop used has since been reinterpreted (Nicol \& Van Dissen, 1997).

Thomson (1980) mapped the Blue Rock Valley in detail, identifying a shallowmarine succession that differs from that found to the east, and O'Brien (1980) documented a number of tephra within the Te Muna Formation in the north of the study area. Dobbie (1982) investigated the factors influencing recementation of the Quaternary limestones, with levels of calcite and aragonite, changes in the terrigenous content, and water flow as the important variables. Rataul (1988) helped to define the characteristics of the recently-described Hautotara and Te Muna Formations, and confirmed that the mudstones of the Te Muna Formation are lacustrine in origin. Cape et al., (1990), interpreted seismic data across the Wairarapa Valley, and correlated significant reflectors in the wider basin to outcrops of Hautotara and Te Muna Formations in the Huangarua Valley.

Recent student projects include Rampton (1997) who mapped and interpreted the Late Neogene sequence within the northern part of the study area, and helped redefine a section of steeply dipping Hautotara and Te Muna Formation overlain unconformably by Ahiaruhe Formation (Nicol \& Van Dissen, 1997). Gammon $(1995,1997)$ documented many stratigraphic sections in the region and attempted to identify a sequence-stratigraphic signature, and Clarke (1998) provides a valuable and detailed investigation into the biostratigraphy of the limestones of the lower Ruakokoputuna River and Makara Stream. Andrews (2001) constrained the depositional environment of the Pukenui Limestone in the Hinakura Road area, showing that the Pukenui Limestone in this area has characteristics generally ascribed to the Hautotara Formation.

A series of papers in the 1990's, first identified, then progressively modified, the ages of a series of tephra in the Wairarapa region, as methods were refined (Shane, 1990, 1991; Shane \& Froggatt, 1991; Shane et al., 1995, 1996). This work in constraining the chronology has been updated by Nicol et al., (2002) who produced a synthesis paper incorporating a wide range of data within the Eastern Wairarapa Valley to constrain the rate and timing of deformation. Formento-Trigilio et al., (2002) focused on the Late Quaternary folding of the study area using terrace 
surfaces deformation, allowing insights into the modern structural processes acting upon the study area.

\subsection{Methods of analysis}

Geological mapping of the region identified the extent of the Hautotara and Te Muna Formations in the area southeast of Martinborough. In addition, mapping of parts of the underlying Pukenui Limestone and overlying Ahiaruhe Formation and Late Quaternary gravels was carried out.

Eight stratigraphic sections were measured in detail through the study area. This was carried out using an Abney level, Jacob's staff, tape and compass. Lithological descriptions and macrofossil identification were carried out on these sections. Tephra, grain size, and bulk macrofossil samples were collected from suitable locations in the stratigraphic sections and throughout the study area.

Macrofossil identification was done where possible in the field, with bulk samples collected from selected beds washed and examined in the Palaeontology Laboratory at Victoria University of Wellington (VUW). Where identification proved to be difficult, samples were referred to, and discussed with, Alan Beu at GNS Science.

Clast shape and fabric data from the conglomerate units of the Te Muna Formation were recorded in the field using callipers and compass, with the length of the A, B and $\mathrm{C}$ axis, roundness, and dip and dip direction of the A-B plane recorded. Corrections for tectonic tilt and stereonet projections were calculated using the StereoWin program. Shape and roundness data of the gravel units of the Hautotara Formation were collected both at outcrops and at VUW.

Grain size analysis of predominantly siliciclastic material under $2 \mathrm{~mm}$ in diameter was carried out on the Beckman Coulter Laser Sizer 13320 at VUW. Sediment preparation for this method of analysis is detailed in Appendix Three. 
Detailed discussion of the preparation of tephra samples for analysis, on the JEOL JXA-8230 Superprobe electron probe microanalyzer in the Geochemistry labs at VUW, is presented at the start of Appendix Four.

\subsection{Notes}

\subsubsection{Map Series}

Land Information New Zealand (LINZ) is in the process of converting New Zealand's topographic mapping system from the NZMS 260 map sheets to the Topo250 and Topo50 sheets. These systems have different coordinate systems, with the easting and northing co-ordinates having moved approximately 200 metres in the new map sheets. As the NZMS 260 map sheets are still the most commonly used at present, and Topo50 to become more used, this thesis will provide a conversion between the two systems in Appendix Seven. Within the body of the thesis, the new Topo50 coordinates will be used.

This thesis covers the area of NZMS 260, Sheet S27 (Lake Wairarapa), and the areas of Topo50, BQ33 (Lake Wairarapa) and BQ34 (Martinborough), although some discussion of sites outside of these regions also occurs (Figure 1.3).

\subsubsection{Grain size}

Grain size data on the Beckman Coulter Laser Sizer 13320 is calculated in microns. To enable comparison with previous work done on the Hautotara and Te Muna Formations, and their modern analogues (Rampton, 1997; Woolfe, 1993, 1995) this data has been converted to phi values.

Raw grain size data is presented in Appendix Four, and the graphs can be viewed alongside the appropriate stratigraphy within Appendix Two. 


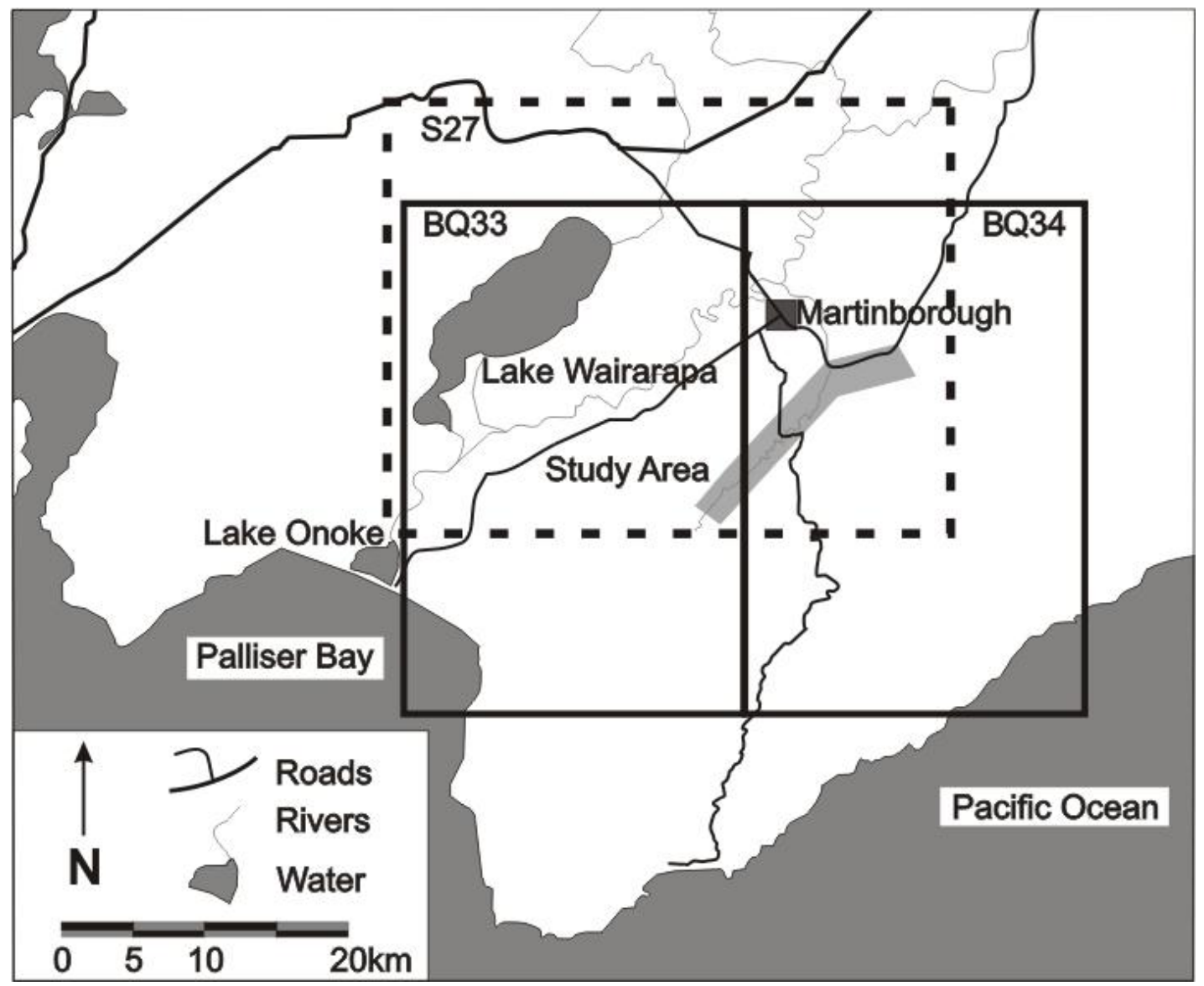

Figure 1.3 Locations of NZMS 260 S27 (Lake Wairarapa) and Topo50 Maps BQ33 (Lake Wairarapa) and BQ34 (Martinborough) used in this thesis.

\subsubsection{Ages}

The ages of units and formations discussed within this thesis are taken from NZGTS 2010/1 - the revised New Zealand Geological Time Scale (Hollis et al., 2010), and a summary of the time-scale applicable to the Hautotara and Te Muna Formations is provided (Figure 1.4). Not represented in Figure 1.4 is the base of the Nukumaruan Stage $(\mathrm{Wn})$ - which occurs at $2.4 \mathrm{Ma}$. The stratotype of the base of the $\mathrm{Wn}$ is identified as the Hautawa Shellbed, which contains the first occurrence (FO) of the cold-water scallop Zygochlamys delicatula in the Wanganui Basin (Beu, 2001). The stratotype for the base of the Castlecliffian Stage (Wc) is currently accepted as the Ototoka Tephra, which has been identified in oxygen isotope stage (OIS) 57, at 1.63 Ma (Beu, 2001; Beu et al., 2004). The boundary between the Castlecliffian and Haweran (Wq) occurs at $0.34 \mathrm{Ma}$ (OIS 10), and is represented by the Rangitawa Tephra. The base of both the Quaternary Period and Pleistocene Epoch is at $2.58 \mathrm{Ma}$ 
(OIS 104), after formal ratification in June 2009 by the International Union of Geological Sciences (Gibbard et al., 2009).

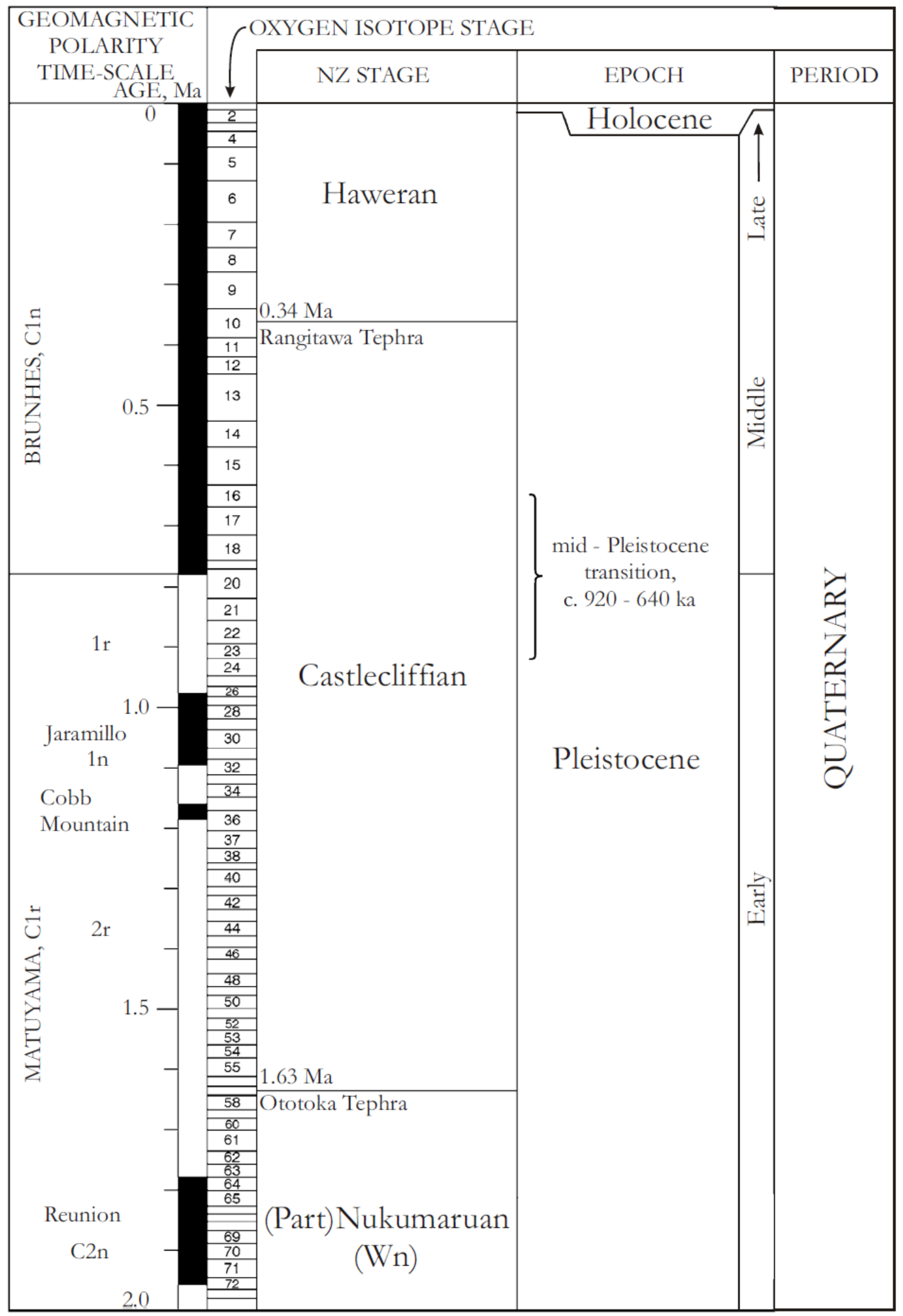

Figure 1.4 New Zealand Pliocene-Holocene time-scale as applied in this study. Position of oxygen isotope stages from Carter \& Naish (1999). Modified from Beu (2006). 


\section{Chapter Two \\ Stratigraphy}

\subsection{General Introduction to Stratigraphy}

The focus of this study is the depositional history of the Hautotara and Te Muna formations, and an examination of their ages and palaeogeography requires a systematic analysis of the stratigraphy. Therefore, this chapter will provide a descriptive overview of the lithostratigraphy of the Hautotara and Te Muna formations within the study area. In addition, a brief examination of the underlying Pukenui Limestone and the overlying non-marine deposits is also warranted, as these formations provide a broader understanding and context of the marine to terrestrial transition and the structural evolution of the study area. Interpretations of the stratigraphy and facies relationships will be presented in Chapters Three and Four. Eight stratigraphic sections are also discussed in this chapter, and these are presented in Appendix Two.

As the number of geological investigations in the southern Wairarapa region increased over the last four decades, the progressive recognition and identification of lithological and biostratigraphic changes in the record forced workers to adopt new formation names, superseding previous definitions (e.g., Collen \& Vella, 1984; Gammon, 1995; Vella \& Briggs, 1971). As a result, the position of boundaries between formations have been modified and adapted. Figure 2.1 provides a short summary of the relevant nomenclature, and the position of formations used in previous works and as described in this study. Figure 2.2 shows the location of the four published type localities, and the proposed reference sections of the Pukenui Limestone and Hautotara Formation.

Of particular note, the contact between the Pukenui Limestone and Hautotara Formation has been placed in various stratigraphic positions (Collen \& Vella, 1984; Gammon, 1997; Nicol et al., 2002). The basis of a revised formal definition of the 
Hautotara Formation, and the lower contact is presented in Section 2.3. This definition closely fits with the interpretation of Gammon (1995) and Rampton (1997).

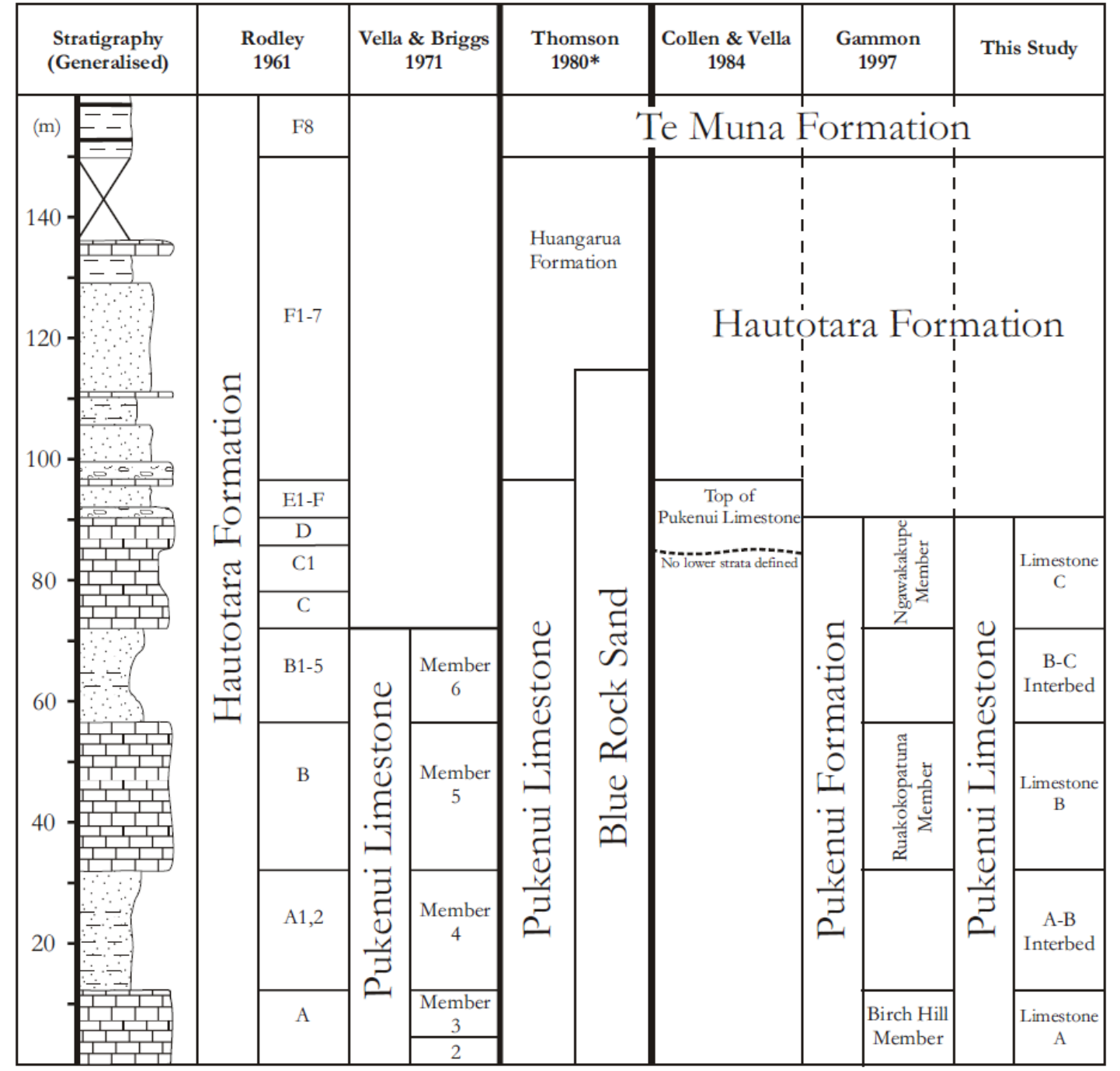

Figure 2.1 Previous authors naming of Eastern Wairarapa Valley stratigraphy and that used in this study. [*Thomson (1980) worked in the Blue Rock Valley, identifying a different lithological succession to that found at the Type Sections]. 


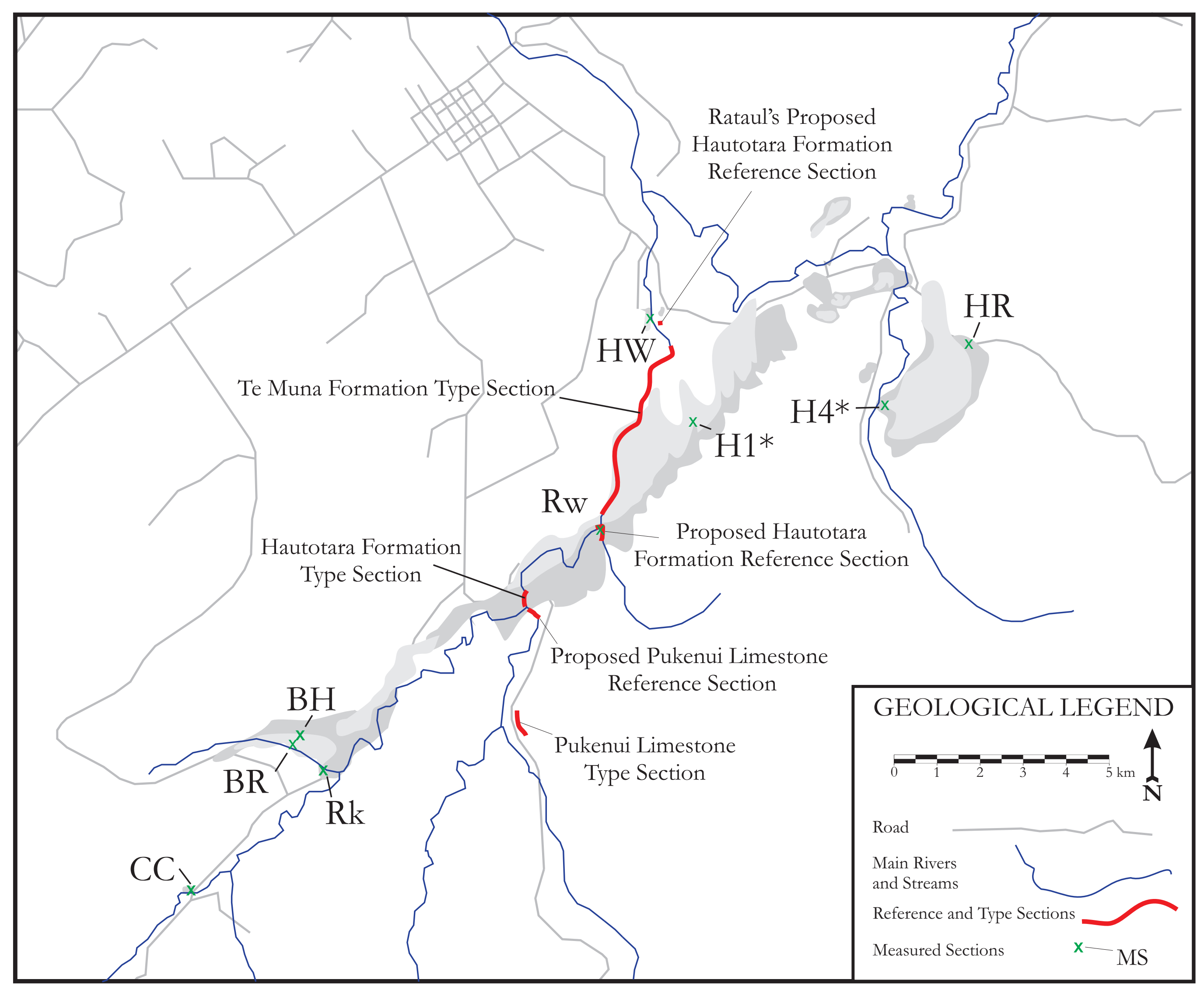

Figure 2.2 Location of Type Sections of the formations discussed in Chapter 2 and of proposed reference sections of the Pukenui Limestone and Hautotara Formations.

Codes to Measured Sections provided in Section 2.7 


\subsection{Pukenui Limestone}

\subsubsection{Name and Definition}

The Pukenui Limestone is a succession of alternating coquina limestones and bluegrey sandstones and mudstones, and was formally defined by Vella \& Briggs (1971), with the formation name derived from the Pukenui 2 Trig Station east of the Ruakokoputuna River (BQ33 035 202). The Pukenui Limestone is the stratigraphically highest formation of the Onoke Group (Begg \& Johnston, 2000; Beu, 1995; Vella \& Briggs, 1971), and comprises five informal members.

The naming of the members is a convention applied by previous workers in the Eastern Wairarapa Valley, with the terminology modified from Rodley (1961), who included the rocks in her Hautotara Formation. Individual limestone beds have been assigned letters, for example, the lowermost is known as "Limestone A", which is in turn overlain by the "A-B Interbed", and so on up the section (Figure 2.1).

\subsubsection{Type and Reference Section}

The type locality of the Pukenui Limestone is northeast of White Rock Road near the Birch Hill Homestead (BQ34 070 234), and is now overgrown. The type locality does not include the "Limestone C" as this was not considered part of the Pukenui Limestone in the original description of Vella \& Briggs (1971). Accessible sections of the Pukenui Limestone are located in streams adjacent to the type locality bluffs, and it is proposed well-defined exposures described by Rodley (1961) and Clarke (1998) in the Makara River near its confluence with the Ruakokoputuna River (BQ34 075 253) are used for a reference section for the Pukenui Limestone (Figure 2.2). This location contains all the members of the Pukenui Limestone under the current usage of the name, and any discussion in this study of the reference section of the Pukenui Limestone refers to this site. 


\subsubsection{Lower Contact}

The Pukenui Limestone conformably overlies the Greycliffs Formation (Figure 2.3) with a gradational contact highlighted by a colour change and increase in Zygochlamys delicatula - found convex and concave up, single and double-valve and variously encrusted with Fosterella tubulatus (Atkins, 1995). Although not formally defined, the exact location of this contact has been shifted from the original stratigraphic location proposed by Vella \& Briggs (1971) (Figure 2.1).

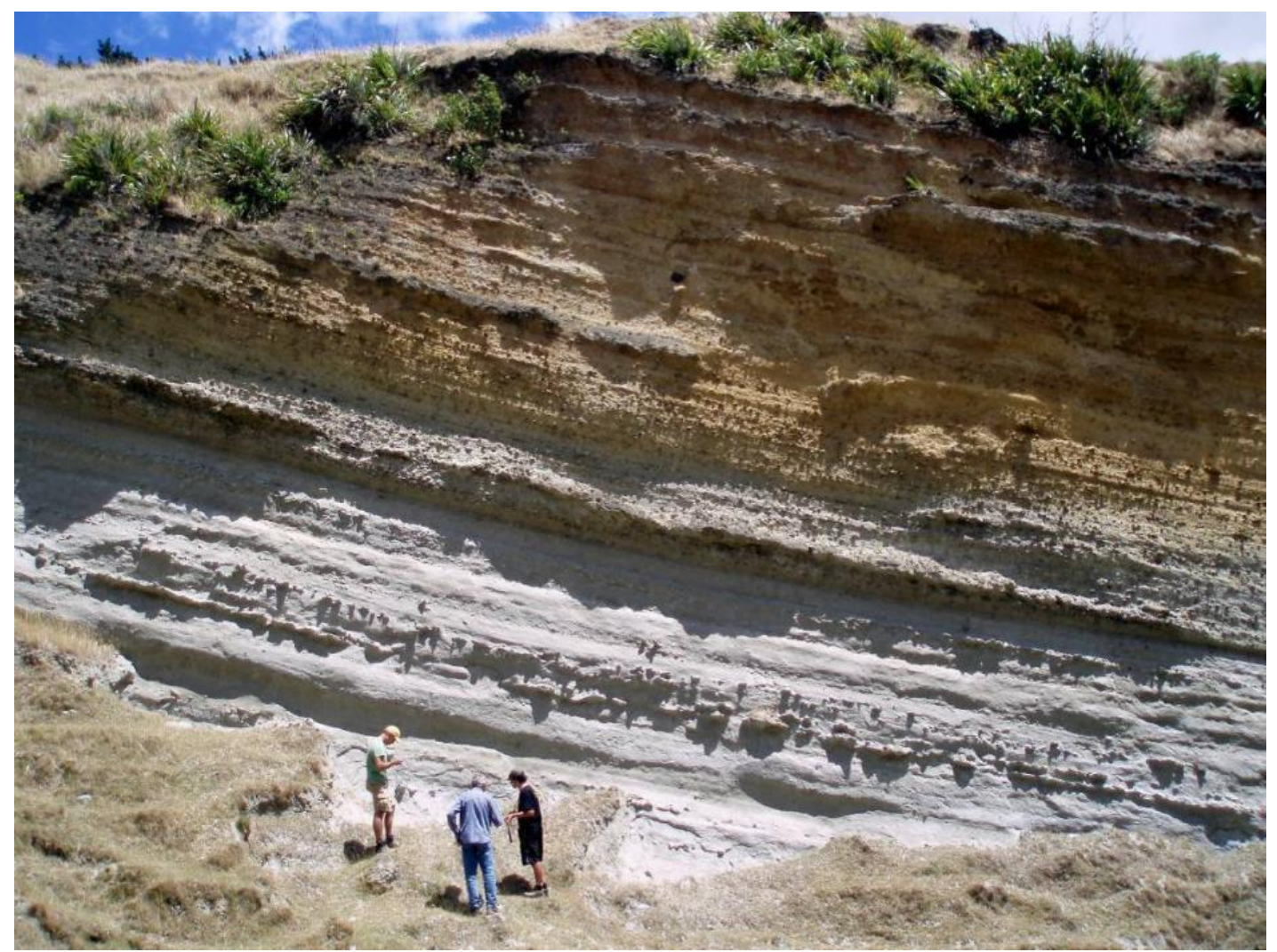

Figure 2.3 Transition from sandy siltstones of the Greycliffs Formation (grey) to the Pukenui Limestone "A" (orange brown), a coquina bed containing abundant Zygochlamys delicatula and Fosterella tubulatus at the base [BQ34 072 234]. 


\subsubsection{Distribution and Thickness}

The Pukenui Limestone occurs in a northeast-southwest trending belt of sporadic outcrops forming hills and high points in the eastern Wairarapa Valley, from the Mt Bruce area in the north, to the southwestern reach of the study area (Dobbie, 1982) (Figure 1.1B, Figure 1.2). A continuous stretch of Pukenui Limestone is found on the Kourarau Hills east of Gladstone and north of the study area. The differentiation between the Pukenui Limestone and the coquina limestones of the Eketahuna Group north of the Wairarapa Valley is largely arbitrary, and more based on historical mapping than any lithological or biological changes (Beu, 1995). Nukumaruan-age Te Aute limestones similar to the Pukenui Limestone are mapped throughout the East Coast Basins as far north as Gisborne (Beu et al., 1980; Beu, 1995; Nelson et al., 2003) (Figure 1.2).

At both the type locality, and the reference section the Pukenui Limestone is approximately 90 metres thick. This appears to be a maximum thickness for the formation. At Hinakura Road in the northern part of the study area, the Pukenui Limestone is much thinner. Dobbie (1982) and Beu (1995) identify a persistently thinner Pukenui Limestone forming ridges in the Wairarapa north of the study area.

\subsubsection{Description}

The Pukenui Limestone is a succession of alternating coquina limestones and bluegrey sandstones and mudstones (Figure 2.1). At the type locality, the formation consists of three coquina limestone members containing characteristic cold-water species such as Zygochlamys delicatula, Jacquinotia edwardsi, Pseudechinus novaezealandiae and Tawera subsulcata, while the interbeds are largely sparsely fossiliferous, although these do include subtropical microfossils (Vella \& Briggs, 1971). The most common macrofossil occurring in the interbeds are the bivalve Panopea zelandica (Vella \& Briggs, 1971; Clarke, 1998). 
It has previously been noted that the Pukenui Limestone contains both minor and major lateral variation in facies (Atkins, 1995; Clarke, 1998). Within the study area the Pukenui Limestone changes significantly, becoming predominantly a muddy, fossil-poor deposit in the northern part of the study area (BQ34 141 315) (Andrews, 2001).

In the wider Wairarapa Valley, the Pukenui Limestone contains fewer members (Dobbie, 1982). This suggests that local effects of tectonism and differential uplift have affected the deposition of the Pukenui Limestone, and that within the study area this has produced the right structural control to record three coquina members.

\subsubsection{Palaeontology and Age}

The Pukenui Limestone is a early- to mid-Nukumaruan formation, but over what period of time the formation was deposited is not particularly well-constrained (e.g., Clarke, 1998; Gammon, 1997; Nicol et al., 2002; Vella \& Briggs, 1971). The presence of the coccolith Gephyrocapsa sinuosa in the "A-B Interbed" is an indicator that this particular horizon is a maximum of $1.8 \mathrm{Ma}$ (Edwards, 1987).

The presence of Zygochlamys delicatula in the Greycliffs Formation near the base of the Pukenui Limestone represents the first Quaternary influxes of cold water into the Ruataniwha Strait, although the specific timing and environment of the deposition of these fossils is subjected to differing interpretations (e.g. Atkins, 1995; Gammon, 1997; Orpin et al., 1998).

The Pukenui Limestone contains no macrofossils that may constrain the formation to a greater resolution than the Nukumaruan (Rampton, 1997). However, the number of cycles postulated to be present in the Pukenui Limestone varies in the literature between two and 10 (e.g. Vella \& Briggs, 1971; Clarke, 1998; Gammon, 1997). The number of cycles, however, must be constrained by palaeomagnetic and biostratigraphic datum, with the key Pukenui Limestone indicators the first occurrence of the coccolith Gephyrocapsa sinuosa in the "A-B Interbed" placed at 1.80 Ma (Edwards 1976; Nicol et al., 2002), the base of the Olduvai subchron found 
in the underlying Greycliffs Formation, and the top near the "Limestone B" (Edwards, 1976, Kennett et al., 1971, Cande \& Kent, 1995).

This study infers the Pukenui Limestone to incorporate three $40 \mathrm{kyr}$ glacio-eustatic sea-level cycles, with the "Eringa Motif" (Chapter Four, Figure 4.3), the dominant signature of the formation. By incorporating the age provided by the first appearance of Gephyrocapsa sinuosa in the "A-B Interbed", the Pukenui Limestone spans the time range of approximately $1.86-1.73 \mathrm{Ma}$.

The Pukenui Limestone contains numerous environmentally important fossils, including Panopea sp. within the interbeds, and the predominately shoreface Tawera subsulcata, prominent in particular on the top of the "Limestone C".

Rare worn Austrovenus stutchburyi and Limnoperna huttoni have been noted within the Pukenui Limestone, and these species indicate the presence of estuarine conditions landward of the Pukenui Limestone observed in the study area (Beu \& Maxwell, 1990; Clarke, 1998).

\subsubsection{Environment of Deposition}

The Pukenui Limestone contains sediment deposited within a range of marine depositional environments between the inner shelf and upper shoreface. The lower Pukenui Limestone contains mostly inner shelf sediments, while the upper Pukenui Limestone is characterised by shallower sediments. The deposition of the Pukenui Limestone represents a shallowing of the study area, inferred to be as a result of uplift of the Hikurangi forearc basin combined with on-going sedimentation into the basin, while also containing an overall glacio-eustatic sea level overprint. Lateral variations in the members of the Pukenui Limestone are attributed to ongoing local effects of tectonism (Nicol et al., 2002). 


\subsection{Hautotara Formation}

\subsubsection{Name and Definition}

The Hautotara Formation contains interbedded siltstones, sandstones, shell beds and conglomerates, and was formally defined by Collen \& Vella (1984). The formation name is derived from the name of the area surrounding the confluence of the Ruakokoputuna and Makara Rivers. The Hautotara Formation incorporates the rocks of the upper Eringa Cyclothem and the entire Huangarua Cyclothem of Vella (1963a).

The name Hautotara has previously been used to describe a variety of rocks. For example, the term "Hautotara beds" was used by Hector (1884) to describe strata in the Manawatu Gorge that resemble outcrops present in the study area, while Couper (1948) and Rodley (1961) used the name Hautotara Formation for the succession from the Greycliffs Formation to the Te Muna Formation.

Thomson (1980) mapped and described the Hautotara Formation rocks in the Ruakokoputuna and Blue Rock Valleys under the name Huangarua Formation, but otherwise the usage remained consistent with the Hautotara Formation definition of Collen \& Vella (1984) (Figure 2.1).

\subsubsection{Type and Reference section}

The type locality of the Hautotara Formation comprises 400 metres of river bank on the true right of the Huangarua River immediately downstream of the Hautotara Bridge (commonly referred to as Banana Bridge) (BQ34 072 254). However, the type locality does not start from the "Limestone $C$ " as this was not considered the lower contact in the original description of Collen \& Vella (1984) (Figure 2.1). The

type locality is poorly exposed, due to the construction of the Hautotara Bridge, and the overgrowth of the river banks. However, outcrops of the type locality sediments 
are now visible on the opposite (western) river bank to that originally described by Rodley (1961).

A number of reference sections have been proposed for the Hautotara Formation (Figure 2.2). Rataul (1988) identified an outcrop in cliffs east of the Huangarua River (BQ34 097 302) as an acceptable reference section. However this is not a complete outcrop of the Hautotara Formation, and is severely restricted in the facies present. Gammon (1995) combined a number of his measured sections into a composite section. Comparison and discussion of facies and facies associations as used by Gammon (1995), and the issues with their use are found in Chapter Four.

Here it is proposed that the $71 \mathrm{~m}$-thick exposure of the Hautotara Formation between Ruawaka Stream and the Huangarua River (centred on BQ34 086 267) become a new reference section for the Hautotara Formation. This section contains the thickest observed Hautotara Formation, and contains a wide range of facies in a nearcontinuous section, constrained by lower contact and upper contacts with the Pukenui Limestone and Te Muna Formation respectively, a feature not found at any other known site. The stratigraphy of this proposed reference section is shown in full as Ruawaka Section in Appendix Two.

\subsubsection{Lower Contact}

The lower contact, with the Pukenui Limestone, has not been well defined, and has conflicting definitions (e.g., Collen \& Vella, 1984; Gammon, 1995; Vella \& Briggs, 1971) (Figure 2.1). Following from the interpretation of recent workers, we here propose the top of the "Limestone C" to be the contact between the two formations. The top of the "Limestone C" is taken to be a prominent indurated Tawera subsulcata-dominated bed, well-exposed at a number of sections, including in the Makara River near its confluence with the Ruakokoputuna River and also in Ruawaka Stream (Figure 2.4). This Tawera subsulcata bed is overlain by a friable well-sorted medium-fine sand of the Hautotara Formation, and this contact probably represents a short hiatus between the formations. Of note, this definition varies from some previous usages, as although this Tawera subsulcata bed is the most 
prominent, it is not the highest stratigraphically. Previous studies, including the definition of the type section by Collen \& Vella (1984), have taken the contact between the Pukenui Limestone and Hautotara Formations to be the highest Tawera subsulcata bed.

\subsubsection{Distribution and Thickness}

The Hautotara Formation is best exposed in a near-continuous band of outcrops flanking the Windy Peak Anticline, from Ngarara Stream in the northeast to just south of Hautotara Bridge in the southwest (Appendix One). The poorly cemented beds of the Hautotara Formation form a prominent break in slope between the underlying, cemented "Limestone C" of the Pukenui Limestone and the lowest massive-to-stratified conglomerate units of the overlying Te Muna Formation. For three kilometres downstream of Hautotara Bridge, the Huangarua River largely flows along strike, cutting through the Hautotara Formation.

The Hautotara Formation is also found within the Blue Rock and Ruakokoputuna Valleys, where exposures are often limited to the base of cliffs, or stream beds. Hautotara Formation beds are also observed to the north of the study area within the Whangaehu Stream Valley, and along the southern flanks of the hills near Oystershell Road (BQ34 120 316). 

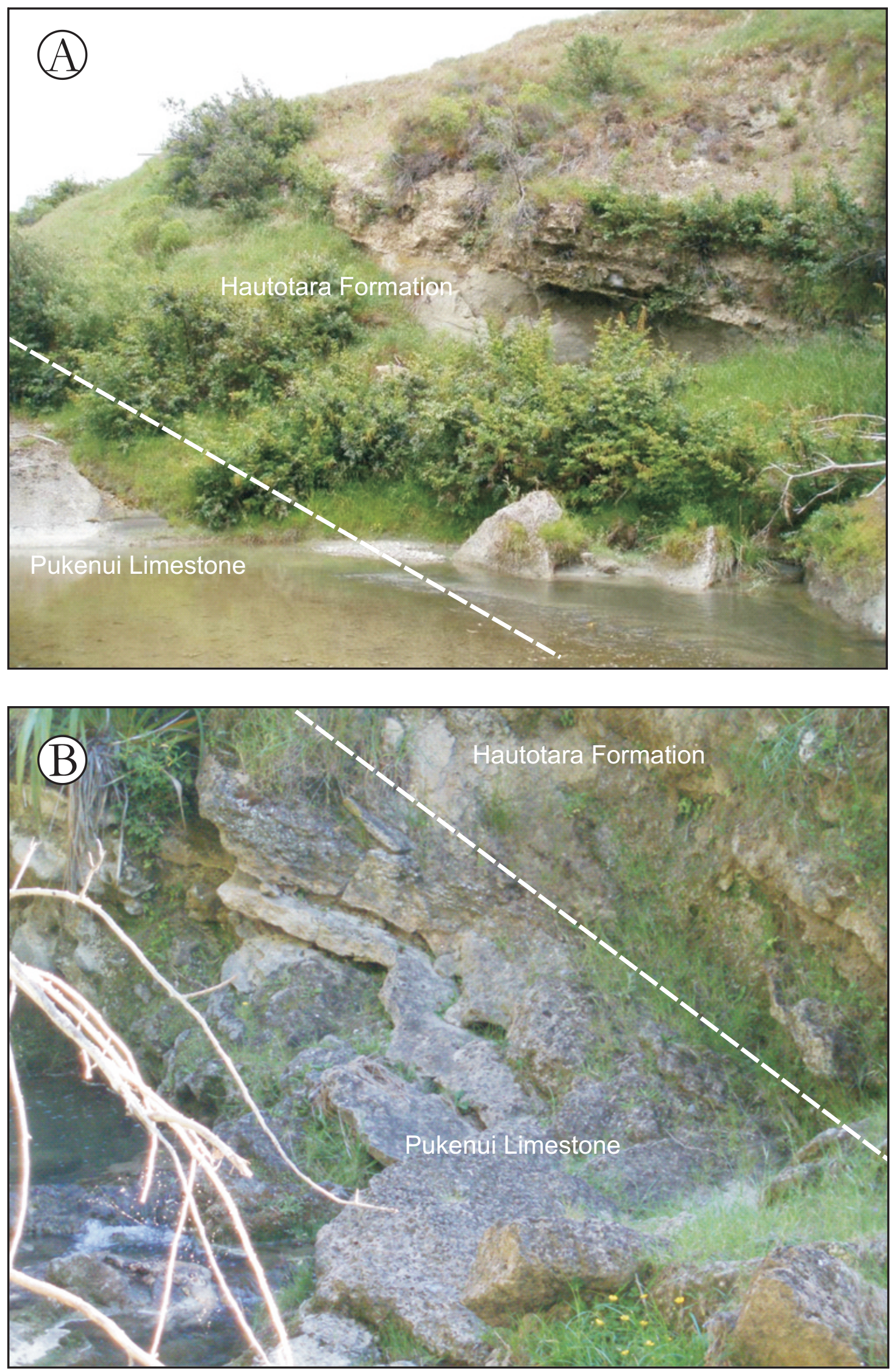

Figure 2.2. Contact (dashed white line) between the Pukenui Limestone and the Hautotara

Formation at: A) Makara Stream (Bq34 075 253), adjacent to the Hautotara Formation type section, below the Pukenui Limestone-Hautotara Formation contact of Collen \& Vella (1984).

B) In Ruawaka Stream, the proposed reference section (BQ34 086 267). 
Outside of the study area, the Hautotara Formation is not as readily identified, and its usage is not always applied under restrictions of its definition. Kennett (1964) identifies Hautotara Formation deposits to the north of the study area, on limbs of the growing Gladstone Anticline at Gladstone (Figure 1.1B). The Wellington Q-Map (Begg \& Johnston, 2000) identifies Hautotara Formation within the sea cliffs at Lake Ferry, to the immediate east of Lake Onoke (Figure 1.1B) (BQ32 793 152). These sediments at Lake Ferry have poorly defined, and often contradictory, ages attributed to them (M. Hannah, pers. comm), although the presence of the Wn to Recent gastropod Zethalia zelandica in a shelly conglomerate, and the moderate dip of the beds suggest the period of deposition of these beds is approximate to that of the Hautotara Formation in the study area.

Collen \& Vella (1984) record 40 metres of Hautotara Formation at the type section, although including the strata below this as proposed by the redefinition increases this to around 70 metres (Rodley, 1961). At the proposed reference section at Ruawaka Stream, 71 metres of Hautotara Formation is exposed. The Hautotara Formation appears to be thickest in the Huangarua Syncline, indicating that the syncline was growing during the depositional period of the Hautotara Formation. Away from the near-continuous band of outcrops flanking the Windy Peak Anticline, the formation is often thin ( $<20$ metres) and outcrops are difficult to find.

\subsubsection{Description}

The Hautotara Formation comprises interbedded siltstones, sandstones, shellbeds and conglomerates, and contains major lateral variation in facies (Figure 2.1; Chapter Three). The Hautotara Formation represents the Quaternary marginal marine deposits of the Eastern Wairarapa Valley associated with the closing of the Ruataniwha Strait and the final emergence of the Wairarapa.

Details of the facies present and their relationships are presented in the following three Chapters. 


\subsubsection{Palaeontology and Age}

The Hautotara Formation is late Nukumaruan, and although representing a period of time with no major biostratigraphic constraints, the timing of deposition can be restricted by evidence from the underlying Pukenui Limestone and overlying Te Muna Formation (e.g. Nicol et al., 2002). Based on new stratigraphic sections and increased resolution of the sequence stratigraphic interpretation, it is inferred deposition of the Hautotara Formation continued into the Castlecliffian stage.

A reverse polarity signature within the "Barytellina siltstone" provides some control on the chronology, with the reversal identified to be from near the Pukenui "Limestone B", to five metres above the Upper Te Muna Tephra in the Te Muna Formation (Collen \& Vella, 1984; Kennett et al. 1971; Shane \& Froggatt, 1991). This time frame corresponds to the Matuyama reversed chron (Naish, 2005).

The palaeontological evidence from the Hautotara Formation supports deposition within the Nukumaruan and Castlecliffian stages. A number of macrofossils prominent within the Hautotara Formation are first identified in the Nukumaruan (Beu \& Maxwell, 1990). Three major indicator species for the start of the Nukumaruan are:

\section{Tawera subsulcata \\ Zethalia zelandica \\ Amalda opima}

These species are the most common identified within the Hautotara Formation, and although they may be variably preserved, a significant proportion appear in situ, and therefore can be reliably used as age diagnostic species.

The gastropod Amalda opima is a Nukumaruan restricted species (Beu \& Maxwell, 1990), and appears within a massive sandstone of at the Ruawaka measured section (Appendix Six). 
A number of macrofossils identified in the Hautotara Formation are extinct, and can limit the upper boundary of the formation to the Castlecliffian. Significantly these include:

\section{Limnoperna huttoni}

Tawera subsulcata

Barytellina crassidens

These species are all identified within the upper Hautotara Formation, with Barytellina crassidens in particular occurring at the Hautotara-Te Muna Formation contact.

The macrofossils identified within the Hautotara Formation are from a range of environments, with Panopea zelandica and Amalda mucronata both species indicative of the inner shelf environment, while Austrovenus stutchburyi, Limnoperna huttoni and Barytellina crassidens all low salinity to estuarine species (Beu \& Maxwell, 1990). Although Limnoperna huttoni has not been identified in situ, the presence of transported valves in shellbeds suggests the appropriate habitat was located nearby.

Further discussion of the relationship between the facies and environmentally restricted taxa is provided in Chapter Three.

This study interprets the Hautotara Formation to incorporate seven and a half sealevel cycles at the Ruawaka measured section. These cycles are believed to be $40 \mathrm{kyr}$ Milankovitch forced glacio-eustatic sea-level cycles, and therefore believed to represent a maximum of $300 \mathrm{kyr}$. This constrains the deposition of the Hautotara Formation between the 1.73 Ma of the top of the Pukenui Limestone, and 1.44 Ma with an angular unconformity with the Te Muna Formation.

The age of the Hautotara-Te Muna Formation contact is believed to vary between sites. This results in the Hautotara Formation incorporating a differing number of sea-level cycles at the various sections. For example, to the north, the Hautotara Formation data from this study and an examination of the work of Rampton (1997) 
suggests the formation incorporates three and a half cycles. This would place the formation in this area between around $1.73-1.60 \mathrm{Ma}$. This is in excellent agreement with age constraints provided by tephra deposits in this region, which places the lowest mudstone of the Te Muna Formation at $1.57 \mathrm{Ma}$ (this study; Nicol et al., 2002).

\subsubsection{Environment of Deposition}

The Hautotara Formation represents a range of marginal marine depositional environments, and contains strata interpreted to have been deposited in settings ranging from inner shelf to estuarine (Chapter 3). Variations in the apparent water depth of these depositional environments are related to Milankovitch-scale glacioeustatic sea-level change with an overprint of regional structural contraction. Previous studies have highlighted non-marine rocks within the formation (e.g. Collen \& Vella, 1984; Gammon, 1997), and although the amplitude of inferred sealevel change is great enough to accommodate both marginal-marine and terrestrial deposition within the Hautotara Formation, no beds observed in this study are able to be confidently assigned to a non-marine origin. Numerous beds observed appear to be reworked from non-marine deposition, and indicate that the lack of non-marine sediments is as a result of erosion during marine transgression. 


\subsection{Te Muna Formation}

\subsubsection{Name and Definition}

The Te Muna Formation is dominated by alternating conglomerates and mudstones, with associated rare sandstones, lignites, palaeosols, loess and tephra deposited in a non-marine environment (Chapter Three). The formation was formally described by Collen and Vella (1984), who named the formation after the Te Muna Station, which is immediately west of the type section (BQ34 089 276).

Rocks of the lower part of the Te Muna Formation are included as part of the Hautotara Formation of Rodley (1961), while a number of informal names were in use for the non-marine strata prior to the formal definition.

\subsubsection{Type section}

The type locality of the Te Muna Formation is exposures on both banks of the Huangarua River for a distance of 3.7 km (Collen \& Vella, 1984) (BQ34 086270 to BQ34 098 302). Here the formation is estimated to be 366 metres thick, and contains 15 members (Collen \& Vella, 1984). However, as this study shows, the formation appears to contain more than these 15 members.

\subsubsection{Lower Contact}

The lower contact of the Te Muna Formation has previously not been well defined, and has been interpreted as either a conformable contact, or an angular unconformity. Collen \& Vella (1984) describe the contact as an angular unconformity over $60^{\circ}$, although later work by Nicol \& Van Dissen (1997) and Rampton (1997) show that in the section described above, steeply-dipping Hautotara Formation beds are overlain by the younger Ahiaruhe Formation, and suggested that poor exposure had resulted in the misinterpretation of the site. In the same area Rampton (1997) also identified the Hautotara-Te Muna Formation contact as near 
conformable, with the "Barytellina mudstone" often immediately underlying the contact.

Here, the contact is believed to be diachronous across the study area, and is variably described as conformable to erosional. At the Ruawaka measured section an angular unconformity up to $9^{\circ}$ has been identified, while soft deformation structures are observed in the underlying Hautotara Formation at the Huangarua West section (Appendix Two).

\subsubsection{Distribution and Thickness}

The Te Muna Formation outcrops in a near continuous strip from the the Hinakura Road measured section, and nose of the Windy Peak Anticline in the north, along the western limb of the anticline, to just north of Hautotara Bridge in the southwest (Appendix One). Outcrops are also present within the Ruakokoputuna and Blue Rock Valleys.

The Te Muna Formation has been tentatively identified within the wider Wairarapa Valley, in particular at a section of fault exposed Quaternary gravels west of Lake Onoke (Begg \& Johnston, 2000), although the notes incorporated into the palynological data used for this correlation does not appear to support this definition.

Cape et al., (1990) trace subsurface reflectors correlated to known outcrops of the Te Muna Formation through the Wairarapa Valley; these show the Te Muna Formation thickening significantly into synforms. At an estimated 366 metres, the type section is the thickest continuous exposed section of the Te Muna Formation. The type section is located on the eastern limb of the Huangarua Syncline (Appendix One), and in the type section the individual beds of the Te Muna Formation are much thicker than those observed elsewhere in the study area. 


\subsubsection{Description}

The Te Muna Formation comprises interbedded conglomerates and mudstones, with rare sandstones, lignites, loess, palaeosols and tephra.

Only examined briefly in this study, the loess and palaeosols (Figure 2.5) are associated with the "Te Muna Twin Tephra" at the type section, and have previously been examined in detail (e.g. Berger et al., 1992; Rataul, 1988). Details of the remaining Te Muna rock types, and their relationships, are presented in Chapters Three, Four and Five.

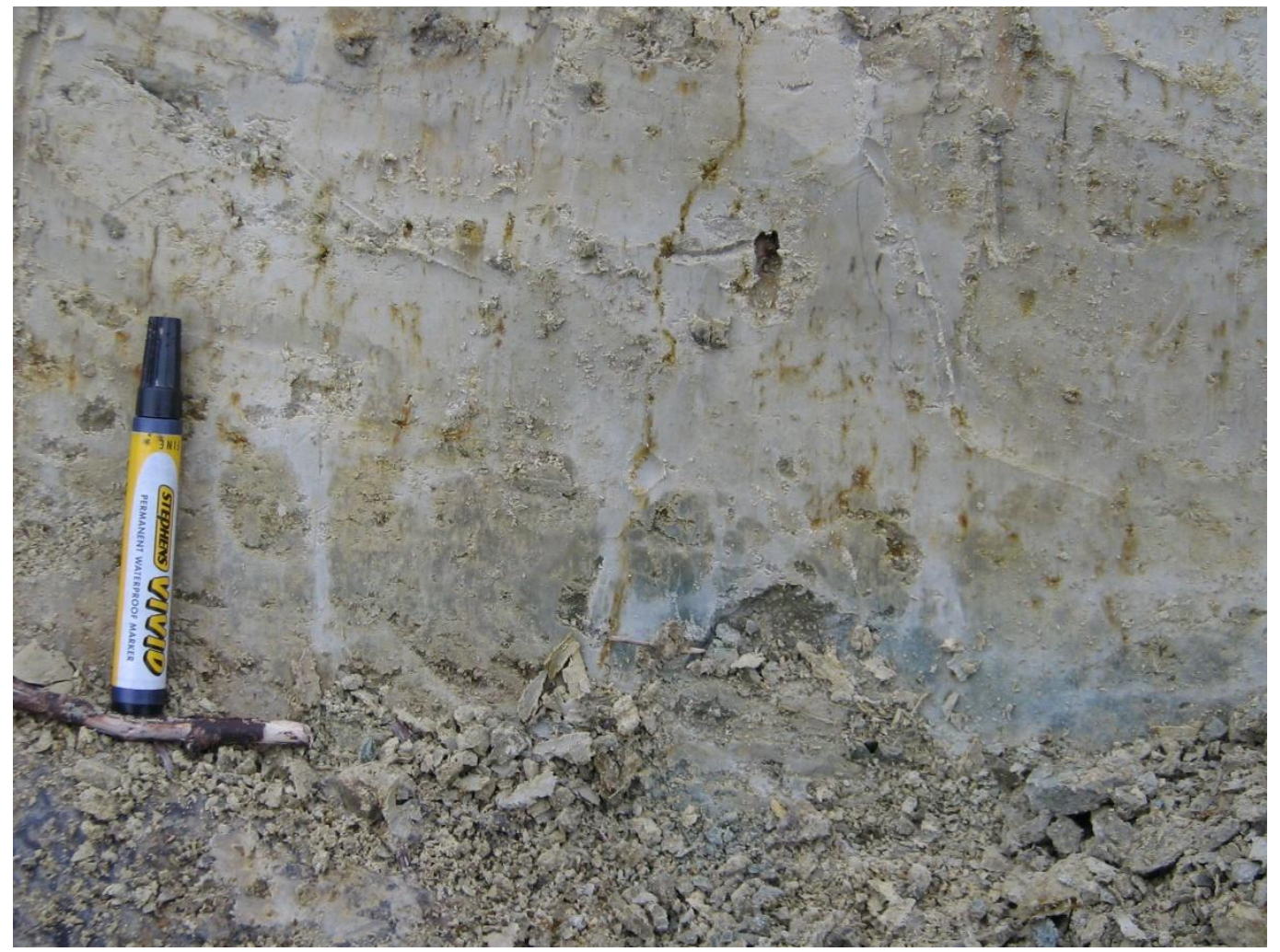

Figure 2.5 Gammate structures in the Te Muna Formation (BQ34 089 276)

\subsubsection{Palaeontology and Age}

The Te Muna Formation does not contain any chronologically significant fossils, although intiaial pollen and plant material analysis derived from the organic and lignitic units indicate a climate similar to the modern day Wairarapa. 
The age controls for the Te Muna Formation are derived from a number of tephra identified within the formation. In particular, the twin tephra of the type section (Upper and Lower Te Muna Tephra) are correlated to the 1.0 \pm 0.03 Ma Potaka and $0.86 \pm 0.08$ Ma Kaukatea Tephra (Collen \& Vella, 1984; Nicol et al., 2002, Pillans et $a l ., 2005)$. A number of tephra are also found in outcrops away from the type section (Table 3.2), and are related to a number of separate events around 1.6 Ma (Allan et al., 2008; Nicol et al., 2002; Rampton, 1997). Utilising ages provided by a number of discreet tephra beds in the lower Te Muna Formation, the age of the base of the formation is placed at $1.58 \mathrm{Ma}$. While the top of the formation lacks precise stratigraphic control, the number of cycles identified at the type section suggests the top of the formation is probably younger than $0.72 \mathrm{Ma}$. Previous workers have places the age of the top of the formation at $0.4 \mathrm{Ma}$ (Collen \& Vella, 1984; Nicol et al., 2002; Rampton, 1997).

\subsubsection{Environment of Deposition}

The Te Muna Formation was deposited in terrestrial settings, with lacustrine mudstones analogous to the modern day environment (Chapter Three; Collen \& Vella, 1984; Rampton, 1997; Woolfe, 1993).

The conglomerates of the Te Muna Formation represent fluvial aggradation during glacial periods (Rampton, 1997). It is believed that as a result of the deteriorating climate and reduced vegetation of a glacial period, an increase in erosion, and river loads, would occur (Collen \& Vella, 1984; Rampton, 1997).

The modern day Wairarapa Valley contains both a marginal-marine lake (Lake Onoke), and a non-marine lake (Lake Wairarapa) (Figure 1.1B). However, within the Te Muna Formation, no evidence of marine influence in the lacustrine sediments has been observed (Rataul, 1988). 


\subsection{Ahiaruhe Formation}

\subsubsection{Name and Definition}

The Ahiaruhe Formation was formally defined by Collen \& Vella (1984), and contains cemented conglomerate, brown mudstone and the $340 \mathrm{ka}$ Rangitawa (formerly Mt Curl) Tephra (Pillans et al., 1996). The Ahiaruhe Formation is named for the area southwest of Gladstone where the type locality is defined.

\subsubsection{Type section}

The type section of the Ahiaruhe Formation is $20 \mathrm{~km}$ north of the study area, in a road cut east of Ahiaruhe Road, $1.5 \mathrm{~km}$ north of the junction with Ponatahi Road (BP34 173 478). In the type section the formation is thin, but Collen \& Vella (1984) suggest it contains a complete stratigraphic record. However, the section does not display the base or the top of the Ahiaruhe Formation.

\subsubsection{Lower Contact}

The Ahiaruhe Formation unconformably overlies the older units of the region (Collen \& Vella, 1984; Rampton, 1997). A 55-60 angular unconformity with Hautotara and Te Muna Formations below the Ahiaruhe Formation is observed in cliffs on the true right bank of Huangarua River, east of the Huangarua West measured section, and vertically above the Hautotara Formation reference section of Rataul (Figure 2.2) (Nicol \& Van Dissen, 1997; Rampton, 1997; Rataul, 1988). Here the base of the formation is channelised (Rampton, 1997).

\subsubsection{Distribution and Thickness}

The Ahiaruhe Formation is approximately 80 metres thick at the type section, and inferred to be a about 41 metres thick in the axis of the Huangarua Syncline (Collen \& Vella, 1984; Rampton, 1997). The Ahiaruhe Formation occurs as scattered 
outcrops in the field area; however, it is more continuous outside of the study area. A sixteen kilometre "belt" of Ahiaruhe Formation with the prominent Ahiaruhe Surface on top, extends from the type section south to the Huangarua River near Martinborough (Collen \& Vella, 1984).

The Ahiaruhe Formation overlies the Te Muna Formation in the southern parts of the study area (Appendix Two), and also occurs within the Huangarua River area towards the north of the study area.

\subsubsection{Description}

The Ahiaruhe Formation contains greywacke conglomerates, loess-rich mudstones, and tephra. The poor sorting and stratification, and significantly larger size of the clasts in the Ahiaruhe Formation are the primary feature used to distinguish between the Te Muna and Ahiaruhe formations (Rampton, 1997; Nicol et al., 2002).

\subsubsection{Palaeontology and Age}

The Ahiaruhe Formation does not contain any chronologically significant fossils, although Moa footprints have been identified within the finer grained units of the Formation (Collen \& Vella, 1984). The Rangitawa Tephra is dated at $340 \mathrm{ka}$, and is observed towards the upper centre of the formation at the type section (Collen \& Vella, 1984; Pillans et al., 1996).

The age of the base of the Ahiaruhe Formation is estimated to be in the vicinity of $400 \mathrm{ka}$, while the Ahiaruhe Surface at the top of the formation is believed to be $20 \mathrm{ka}$ (Collen \& Vella, 1984; Nicol et al., 2002; Rampton, 1997).

\subsubsection{Environment of Deposition}

The Ahiaruhe Formation was deposited in terrestrial settings analogous to the modern day environment. The deposits of loess, lacustrine mudstone and fluvial conglomerates are also observed within the Te Muna Formation stratigraphy. 
However, as the conglomerates are poorly sorted, weakly stratified, and contain significantly larger clasts than the Te Muna Formation, this indicates the rivers transporting these sediments differ in flow regime to the Te Muna Formation (Rampton, 1997).

\subsection{Younger Sediments}

The study area also contains a succession of terrace gravels deposited since the Last Interglacial (Vella 1963b; Formento-Trigilio et al., 2002). These aggradation gravels in the study area are sourced from the Aorangi Ranges, and have been transported by the modern rivers and streams of the area. These conglomerates largely cover the Early Pleistocene succession of sediments in valleys of the Blue Rock, Ruakokoputuna, Huangarua and Whangaehu Rivers. The major terrace mantling the formations studied is the Waiohine Surface, a widespread aggradation surface of the Wairarapa Valley (Vella 1963b).

These younger deposits which also include material in the banks and channels of the rivers, are not mapped, or described in further detail in this study. Further detailed information on these terrace deposits can be found in a recent study provided Formento-Trigilio et al., (2002).

\subsection{Section Descriptions}

Seven well-exposed outcrops were selected for detailed measured sections. The stratigraphic columns are presented in Appendix Two, and the locations of these sections are shown in Figure 2.2.

\subsubsection{Hinakura Road Section (HR)}

Grid Reference: BQ34 145304

The Hinakura Road Section is a north-to-northwest-facing road cut on Hinakura Road, 1.7 kilometres east of the Cannock Road intersection. The 48 m-thick 
measured section contains 18 units, and ranges from the Pukenui Limestone to the lower Te Muna Formation.

This measured section builds on the works of Rampton (1997) and Andrews (2001), who documented the underlying Pukenui Limestone. Although exposure is limited, and only approximately $15 \%$ of the $34 \mathrm{~m}$ thickness of Hautotara Formation is documented (Figure 2.6A), it is nonetheless important, as the overlying Te Muna contains two tephra layers within the lower sandy mudstone units.

\subsubsection{Huangarua West Section (HW)}

Grid Reference: BQ34 094303

The Huangarua West Section is within cliffs west of the Huangarua River, one kilometre south of the Huangarua River Bridge on Hinakura Road. The measured section contains 10 units of the upper Hautotara Formation and lower Te Muna Formation, and represents a combined 40 metres of these formations.

The Huangarua West Section is located close to the hinge of the Huangarua Syncline, and south of major traces of the Huangarua Fault. On the true right bank of the Huangarua River, opposite this section (Figure 2.6B), Rampton (1997) records 700 metres of continuous stratigraphy, including the Hautotara and Te Muna Formations.

\subsubsection{Ruawaka Section $(\mathrm{Rw})$}

Grid Reference: BQ34 086267

The Ruawaka Section extends from the upper contact of the Pukenui Limestone, in a westward flowing stream (here named the Ruawaka Stream) to the lowermost Te Muna Formation on the western bank of the Huangarua River, immediately before a right-hand dog-leg bend in the river. The Hautotara Formation is 71 metres thick in this section, and 33 metres of the Te Muna Formation is also documented. The Ruawaka Section records 52 units, from the Pukenui $\mathrm{C}$ to the lower Te Muna Formation. 

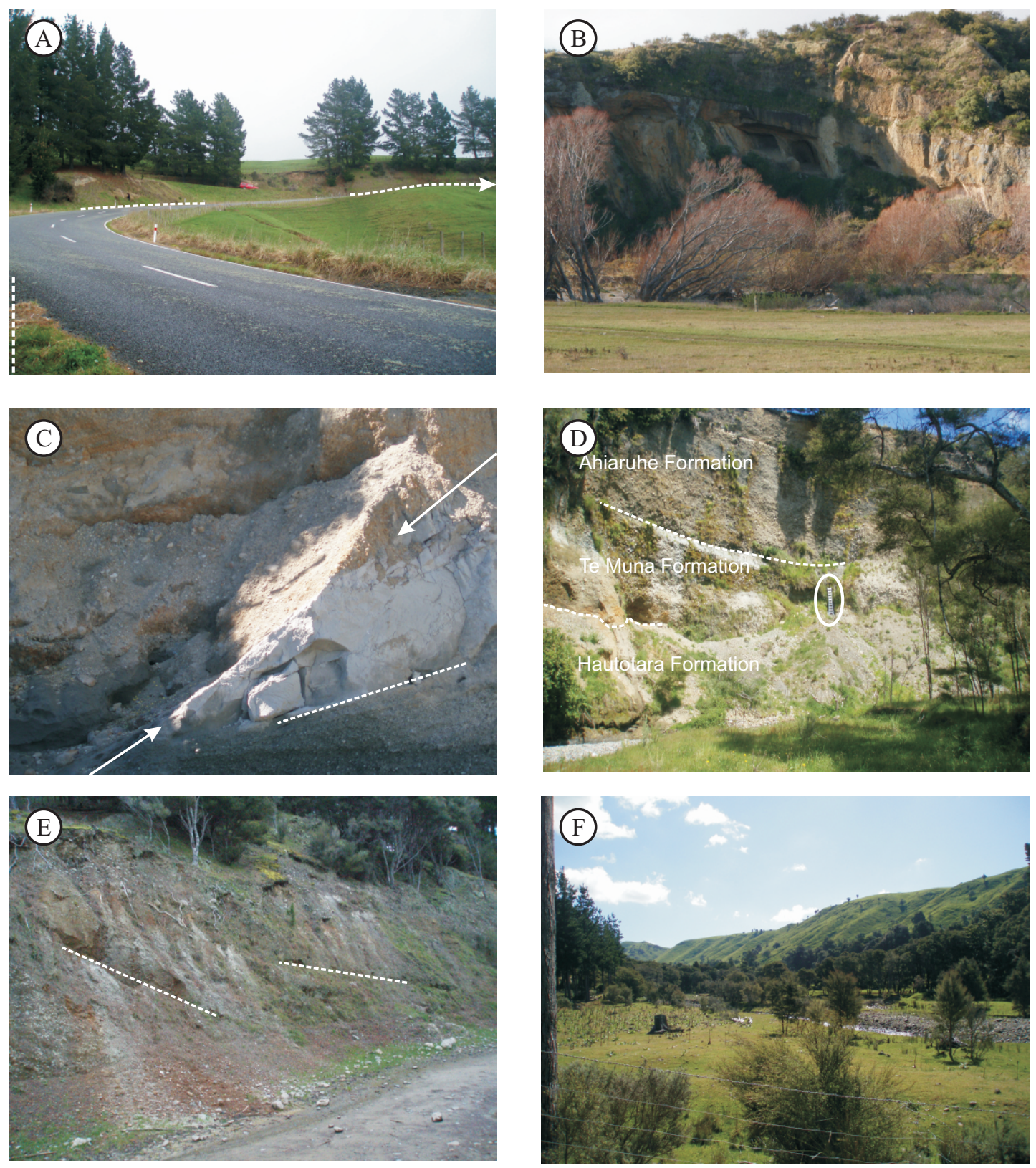

Figure 2.6 A) View of the Hinakura Road measured section. Dashed lines show extent of exposures. Photo taken from the Pukenui C bed. B) View of Rataul's (1988) reference section from the Huangarua West measured section. The strata in this photo has been the focus of numerous studies (e.g. Lamb, 1987; Lamb \& Vella, 1987; Nicol \& Van Dissen, 1997).

C) Expression of faulting (arrowed, orientation of fault plane 037/NW/43) in Te Muna Formation at the Ruawaka Measured section. Attitude of bedding shown by dashed line. D) Ruakokoputuna Bridge Cliff Section, showing relationship and contacts (dashed lines) between the Hautotara, Te Muna and Ahiaruhe formations. Ladder (circled) is $\mathbf{3 . 5} \mathbf{~ m}$ high.

E) Blue Rock Race Section, showing a shallowing of dips up section (dotted line approximately along contacts between units). F) View west into the Blue Rock Valley from near the Blue Rock measured sections. The hills to the right are dissected greywacke highs, and have numerous slips of younger strata, similar to the one containing the BH section. 
At Big Bend (BQ34 079 263), to the south of the Ruawaka Section, the uppermost beds of the Hautotara Formation are exposed, and consists of the "Austrovenus sandstone" containing Barytellina crassidens and Austrovenus stutchburyi. However this horizon has been truncated by the overlying Te Muna Formation and is therefore not preserved in the Ruawaka Section. The Hautotara-Te Muna Formation contact represents an angular unconformity with a dip of $9^{\circ}$.

Gammon (1995), records two sections of the Hautotara Formation within the area of this measured section, although the interpretation of the region differs from this study. In particular, Gammon identifies a fault running between sections 4 and 5 of his study (Gammon, 1995). However, no fault was identified within the Hautotara Formation at this site, and there appears to be no repeat of the stratigraphy as proposed by Gammon (1995). A fault that can be traced to outcrops at Big Bend and the Makara River is identified in the lower Te Muna Formation (Figure 2.6C; Appendix One).

\subsubsection{Ruakokoputuna Bridge Cliff Section (Rk)}

Grid Reference: BQ33 038225

The Ruakokoputuna Bridge Cliff Section is $400 \mathrm{~m}$ upstream of the Ruakokoputuna Road Bridge, a north-facing exposure on the true right bank of the Blue Rock Stream (Figure 2.6D). This section contains $16 \mathrm{~m}$ of upper Hautotara Formation strata, represented by 11 units, overlain by $22 \mathrm{~m}$ of Te Muna and Ahiaruhe Formation conglomerates and mudstones, and a veneer of younger terrace deposits.

Although the Ruakokoputuna Bridge Cliff Section only contains the upper Hautotara Formation, lower Hautotara Formation units are found between the Pukenui Limestone, on the eastern bank of the Ruakokoputuna River, and the base of this site. Grain size data for some of these Hautotara Formation beds are presented in Appendix Three, and a macrofaunal list is included in Appendix Six. 
The lower contact of the Te Muna Formation is a wavy contact with relief of 2.3 metres, almost completely eroding the upper unit of the Hautotara Formation in most places. The upper contact of the Te Muna Formation with the Ahiaruhe Formation is subtle, and is identified based upon clast size, due to the lack of other distinguishing features.

\subsubsection{Blue Rock Race Section (BR)}

Grid Reference: BQ33 026229

The Blue Rock Race Section is on a new farm race (track) cutting dropping from the Waiohine Surface south of the Blue Rock Stream down to the stream bed. Eight units of the Te Muna Formation crop out at this $10 \mathrm{~m}$ outcrop. The outcrop consists of alternating sandy mudstones and massive-to-stratified conglomerate beds, with the contacts between the youngest units having a significantly shallower dip to the oldest (Figure 2.6E), allowing the rate of structural growth in the valley to be determined (Chapter Five).

\subsubsection{Blue Rock Hautotara Section (BH)}

Grid Reference: BQ33 026231

The Blue Rock Hautotara Section is 150 metres north of the Blue Rock Race Section, and is located on a rotated slumped block, covering part of the unpublished stratigraphic column of the Blue Rock Valley produced by Thomson (1980) (Figure 2.6F). The Blue Rock Hautotara Section contains three units of the Hautotara and Te Muna Formations over eight metres, showing the transition between the two formations. Not far above this site, within the lowermost mudstone of the Te Muna Formation is the highly weathered "Duggan Ash" (also called the Blue Rock Tuff), which has previously been dated at approximately 1.57 Ma (Shane \& Froggatt, 1991; Thomson, 1980). 


\subsubsection{Clay Creek Section (CC)}

Grid Reference: BQ33 014203

Exposed in cliffs on the true left bank of the Ruakokoputuna River, immediately west of the Clay Creek Bridge (the bridge itself is built upon the Pukenui C), this section is $21 \mathrm{~m}$ thick, and contains eight Hautotara Formation units above the Pukenui Limestone. The Clay Creek Section represents the southernmost extent of identified Hautotara Formation in the Ruakokoputuna River Valley. 


\section{Chapter Three \\ Facies Analysis}

This chapter provides an objective facies analysis of the Hautotara and Te Muna Formation strata cropping out in the study area. This has been constructed from objective field observations, and supplemented by grain size and faunal information, allowing a facies scheme to be developed for the beds.

The aim of creating this facies scheme is to relate beds from a number of sites and measured sections, allowing the recognition of deposits formed under similar depositional processes. The sedimentological and palaeontological characteristics of the individual facies allow interpretations about the character of the depositional environments these facies were formed in.

By analysing the beds in association with those above and below, successions are repeatedly recognised, strengthening the interpretations, and as a result the understanding of the development of a formation is greatly enhanced. Chapter Four will build on this facies scheme to identify the stratigraphic architecture of the Hautotara and Te Muna formations.

Numerous facies have previously been described in the Hautotara and Te Muna formations (e.g., Collen \& Vella, 1984; Gammon, 1995; Rampton, 1997; Rataul, 1988). These studies show that significant vertical and lateral variations of facies occur over relatively short distances. Previous workers have distinguished their facies through a number of varying attributes, and therefore only a passing mention of these previous descriptions is provided in the following chapters where they can appropriately enhance the work. 


\subsection{Introduction to the Facies Scheme}

Walker \& James (1992) defined the term facies as "a body of rock characterised by a particular combination of lithology, physical and biological structures that bestow an aspect different from the bodies of rock above, below and laterally adjacent". Using this definition, a total of eighteen different facies have been identified in this study. In this study, the term subfacies is used to describe sediment that indicates a depositional change within the same environment. The facies and their primary characteristics are summarised at the end of the chapter in Table 3.3. Thirteen of the facies may be characterised as siliciclastic dominated, and five as bioclastic dominated facies.

Grain size is often related to depositional energy (Dunbar \& Barrett, 2005), and for the marginal marine and shallow-water environments of an open coastline in particular, wave activity. Although Perrett (1990) showed that grain size can be a reliable indicator of palaeobathymetry using a modern day setting, this study only uses grain size as a comparative tool for facies analysis, and not as a detailed determiner of depth (Figure 3.1).

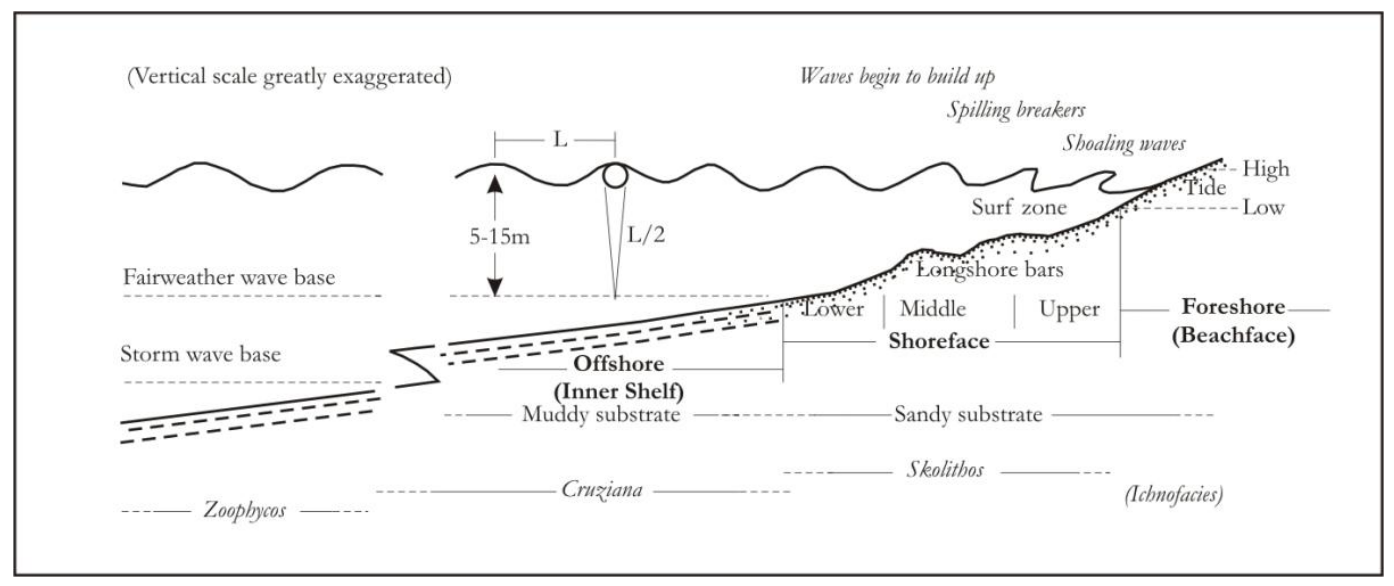

Figure 3.1 The wave base setting of an open coast shelf to shoreface profile with marine environments as used in this study. The approximate location of marine ichnofacies is also provided. Modified from Walker \& James p. 219 (1992). 


\subsection{Facies C - Conglomerates}

Four conglomerate facies are defined in the study area, and are distinguished based on variations in sedimentary structures, fossil content, clast shape, size and sorting. The massive-to-stratified conglomerate $(\mathbf{C m})$ is the most common conglomerate facies within the study area and the dominant facies of the Te Muna Formation. The fossiliferous conglomerate $(\mathbf{C f})$, gravel shellbed $(\mathbf{C g})$, and the shelly conglomerate (Cs), are all distinctly different to the $\mathbf{C m}$, occur only in the Hautotara Formation, and are proportionally minor components of the stratigraphy of the study area. The distinctions between the latter three conglomerates are primarily based upon the proportion and preservation of fossils, the species identified, and the contents of the matrix.

Although dominated by greywacke clasts, the conglomerates also contain rare chert and bored mudstone clasts. Rare fossil branches and logs are found in the $\mathbf{C m}$, a single rounded igneous clast of unknown provenance was identified in a Cs bed, and an exotic rounded limestone clast was collected from the $\mathbf{C g}$ facies. A wide range of molluscan fossils are encountered in the fossiliferous conglomerate and gravel shellbeds.

\subsubsection{Conglomerate - Massive to Stratified (Cm)}

The massive-to-stratified conglomerate facies $(\mathbf{C m})$, is an orange-brown to brown, moderate to well-cemented, faintly-bedded, greywacke-dominated conglomerate with rare chert clasts. The $\mathbf{C m}$ facies is poorly- to well-sorted, and clast supported. Clasts vary from well-rounded to angular, and fossils are restricted to rare large logs and branches (Figure 3.2A). The largest clasts are found in the south of the study area, where the maximum size recorded is $28 \mathrm{~cm}$, while no clasts are observed greater than $8 \mathrm{~cm}$ in the northern part of the study area (Figure 3.3B).

Cm beds range in total thickness from $<1 \mathrm{~m}$ in the southwest of the study area to approximately 40 metres at the type section (Collen \& Vella, 1984). The lower contact of the $\mathbf{C m}$ facies is erosional and channelised, on a decimetre-to-metre scale, 

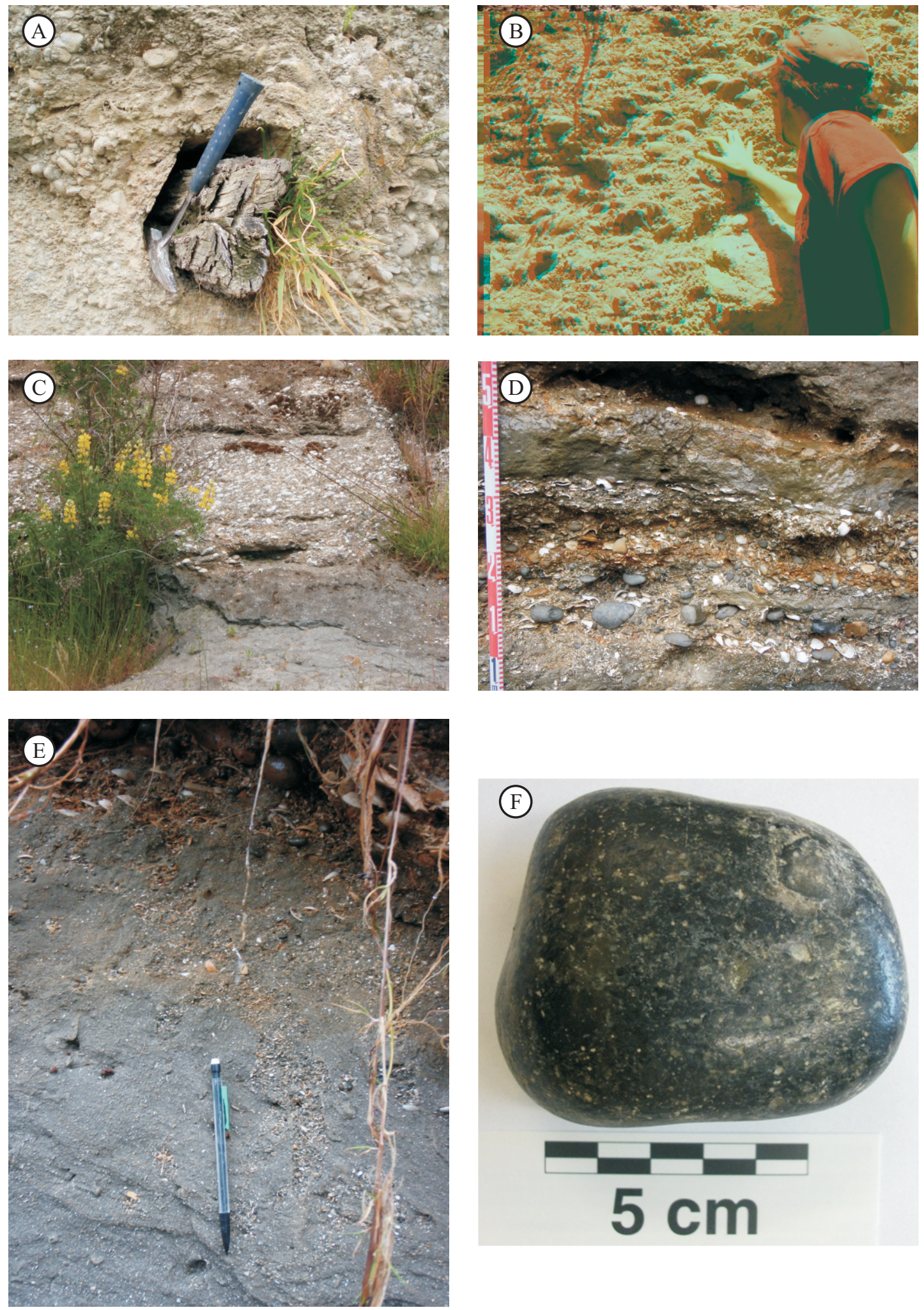

Figure 3.2 A) Fossil log of the Cm facies, from the Te Muna Formation downstream of

Hautotara Bridge. B) Clasts of the $\mathrm{Cm}$ facies in the $\mathrm{HW}$ measured section. These are significantly smaller than those observed in the south of the field area. C)Upper surface of the Cf facies, with numerous worn fossils. D) Stratification present in the Cg facies. E) Burrows from the base of the $\mathrm{Cg}$ facies into the underlying sandstone bed. F) Well rounded igneous clast of unknown providence collected from the Cs facies of bed Rw 42. 
and rarely contains deformation structures (more information on the lower contact in Chapter 5).

\section{Depositional Environment}

Cm was deposited under a range of fluvial energy conditions in a braided river system. Evidence for this includes imbrication, shape and size of the clasts, and other sedimentary features including channels and lens-shaped beds (bar deposits) and the orientation of the numerous fossil logs (Figure 3.2A). The sedimentary structures in the $\mathbf{C m}$ facies are comparable to those observed in the $\mathrm{Gm}$ and $\mathrm{Gp}$ facies of Browne \& Naish (2003) in late Quaternary terrestrial deposits of the Canterbury Plains.

All $\mathbf{~ C m}$ beds in this study have been identified in the Te Muna Formation; however Rampton (1997) has massive conglomerates in the Hautotara Formation in sections located on the western flank of the Windy Peak Anticline. Collen \& Vella (1984) noted that clasts within the conglomerate units of the Te Muna Formation decrease in sorting and rounding up-section, while Rampton (1997) identified a significant reduction in the levels of stratification and imbrication in the younger Te Muna conglomerates. This is consistent with observations of the $\mathbf{C m}$ facies in the Te Muna Formation across the study area, with clast size increasing both up-section and also to the south; the inferred major source of Te Muna Formation clasts.

\subsubsection{Conglomerate - Fossiliferous (Cf)}

The conglomerate - fossiliferous (Cf) facies is a grey to yellow-brown, moderatelyto-non-cemented, highly fossiliferous conglomerate with a shellhash matrix (Figure 3.2C). Cf is matrix to clast supported and contains well-rounded to angular clasts of greywacke with rare bored mudstone, with a maximum clast size of $20 \mathrm{~cm}$.

The proportion of molluscan macrofossils increases from the base to the top of the $\mathrm{Cf}$ facies. Species identified within the $\mathrm{Cf}$ facies range from marginal marine to inner shelf species (Table 3.1; Appendix Six) and are worn and fragmented. The upper 
surface of the Cf has common scallops, Tucetonia laticostata and Alcithoe arabica, all worn and are distinct from those of the assemblage within the $\mathrm{Cf}$.

The maximum thickness of $\mathbf{C f}$ is $60 \mathrm{~cm}$, and the lower contact of the facies is erosional, containing burrows extending into the underlying sandstone facies. The upper contact is a planar, often winnowed, surface with worn fossils of epifaunal species known to inhabit gravel substrates (Beu \& Maxwell, 1990).

\section{Depositional Environment}

The $\mathbf{C f}$ facies is interpreted as being formed in a high-energy setting such as a channel within a semi-enclosed embayment. The worn and fragmented character of the fossils identified within the $\mathbf{C f}$ facies indicates wave scour and transportation of these fossils has occurred, and therefore the mixed fauna cannot be considered characteristic of the environment the $\mathbf{C f}$ facies was deposited within. Instead, the assemblage can be viewed as a combination of a variety of nearby settings, as it is likely that these species have been reworked and redeposited by strong currents, which have also transported the gravel clasts from a proximal source.

Although the fossils within the $\mathbf{C f}$ facies are not able to restrict the environment of deposition, the species found on the upper surface of the facies are characteristic of an assemblage that prefers gravel substrate in a relatively high-energy setting, and are interpreted to have been preserved in situ in a tidal channel within a semienclosed embayment. This assemblage is similar to those identified in modern Northland harbour entrances (Bland, 2006).

\subsubsection{Stratified Gravel Conglomerate $(\mathrm{Cg})$}

The stratified gravel conglomerate facies $(\mathbf{C g})$ is a blue-grey, moderately-cemented, clast supported, poorly-sorted fossiliferous conglomerate. Cg consists of wellrounded to sub-rounded clasts of greywacke up to $11 \mathrm{~cm}$, and also contains rare chert and bored mudstone. 
Fossils within Cg vary from fractured to whole and worn. The fossils include species that are restricted to near-shore environments and also include specimens that range from near-shore to mid-shelf settings. Species identified in the $\mathbf{C g}$ facies commonly include Tawera subsulcata, Zethalia zelandica, Zegalerus tenuis and Glycymeris shrimptoni. The fossils of the $\mathbf{C g}$ facies are variably distributed throughout the beds, often in faint horizons, which distinguish this facies from the $\mathbf{C f}$ facies, in which the proportion of fossils increases towards the top of the bed (Figure 3.2D).

$\mathbf{C g}$ is a thin facies, with a maximum thickness of $30 \mathrm{~cm}$. The lower contact is either erosional and wavy or rapidly gradational. When overlying a sandstone lithology, burrows infilled with $\mathbf{C g}$-derived sediment extend up to $60 \mathrm{~cm}$ from the lower contact into the underlying bed (Figure 3.2E). The upper contact of the $\mathbf{C g}$ facies is conformable and gradational up to $10 \mathrm{~cm}$.

\section{Depositional Environment}

The $\mathbf{C g}$ facies is interpreted as being a fluvially-sourced conglomerate deposit reworked within a semi-protected beachface environment. The clasts of the $\mathbf{C g}$ facies were deposited directly into the marine environment by a nearby river, and have been transported within the intertidal zone. The clasts are therefore believed to have developed their discoid shape and well-rounded-to-sub-rounded characteristic within a wave-energy environment. Although the species present in the $\mathbf{C g}$ beds are from a variety of environments and depths, many are fractured and abraded; whilst many of the species are also consistent with a near-shore environment. Wave energy appears to be lower than similar facies to the north, and this is interpreted to be as a result of some protection provided by shoaling highs (potentially islands) to the west of the areas where $\mathbf{C g}$ has been observed.

\subsubsection{Conglomerate - Shelly (Cs)}

The shelly conglomerate facies (Cs) is a grey to brown, moderately- to wellcemented, fining-up, fossil-poor, clast supported conglomerate. Cs is predominantly comprised of greywacke clasts, although it does contain rare chert, bored mudstone, 
and also includes a well-rounded igneous clast of unknown provenance (Figure 3.2F). It is possible this clast has come from an outcrop some distance to the east of the study area (Collen pers comm). Cs is poorly sorted, and contains well-rounded to sub-rounded clasts up to $11 \mathrm{~cm}$ across, with a sandy matrix that becomes increasingly shell-rich up unit (Figure 3.3A). The clasts of the Cs facies often fine up to granule.

The fossils are predominantly bivalves and typically too abraded and fractured to be identified, although Austrovenus stutchburyi, Ostrea chilensis and the gastropod Antisolarium egnum have been collected from various beds. The Cs facies is up to $50 \mathrm{~cm}$ thick. Where the lower contact is clearly observed, Cs contains shell hash and granule-rich burrows up to $3 \mathrm{~cm}$ wide, extending $50 \mathrm{~cm}$ into the lower unit (Figure 3.3A).

\section{Depositional Environment}

Cs is inferred to represent reworked fluvial gravels within a high-energy intertidal setting. Cs beds contain highly worn shells, and well- to subrounded clasts, although some mudstone clasts are extensively bored. Large infilled burrows extending down from the base of the Cs facies suggest a period of sediment starvation before the deposition of Cs, and the increase in shell material up-unit represents an increase in marine influence. The presence of Austrovenus stutchburyi in some beds suggests that the Cs facies has incorporated marginal-marine sediments, while Ostrea chilensis and Antisolarium egenum near the top of the facies probably represent species living on or near the Cs facies substrate. Unlike the $\mathbf{C g}$ facies, the Cs has a low volume of macrofossils and does not show a great diversity of species (Table 3.1). 
Facies

\begin{tabular}{|c|c|c|c|}
\hline $\mathrm{Cm}$ & $\mathrm{Cf}$ & $\mathrm{Cg}$ & $\mathrm{Cs}$ \\
\hline
\end{tabular}

Common fossils

\begin{tabular}{|c|c|c|c|}
\hline $\begin{array}{l}\text { Logs and } \\
\text { branches }\end{array}$ & $\begin{array}{c}\text { Glycymeris shrimptoni } \\
\text { Tucetona laticostata } \\
\text { Zygochlamys delicatula } \\
\text { Ostrea chilensis } \\
\text { Purpurocardia purpurata } \\
\text { Paphies australis } \\
\text { Tawera subsulcata } \\
\text { Dosinia subrosea } \\
\text { Trochus tiaratus } \\
\text { Zethalia zelandica } \\
\text { Zeacolpus vittatus } \\
\text { Pelicaria vermis } \\
\text { Struthiolaria papulosa }\end{array}$ & $\begin{array}{l}\text { Glycymeris shrimptoni } \\
\text { Tawera subsulcata } \\
\text { Micrelenchus sp. } \\
\text { Zethalia zelandica } \\
\text { Zegalerus tenuis } \\
\text { Amalda australis } \\
\text { Alcithoe arabica }\end{array}$ & $\begin{array}{c}\text { Ostrea chilensis } \\
\text { Austrovenus } \\
\text { stutchburyi }\end{array}$ \\
\hline
\end{tabular}

Characteristics of the fossils

\begin{tabular}{|l|l|l|c|}
\hline Uncommon & Crushed, to whole and worn & Fractured, to whole and worn & Worn \\
and fractured \\
\hline
\end{tabular}

Table 3.1 Common fossils of the four conglomerate facies of the study area 

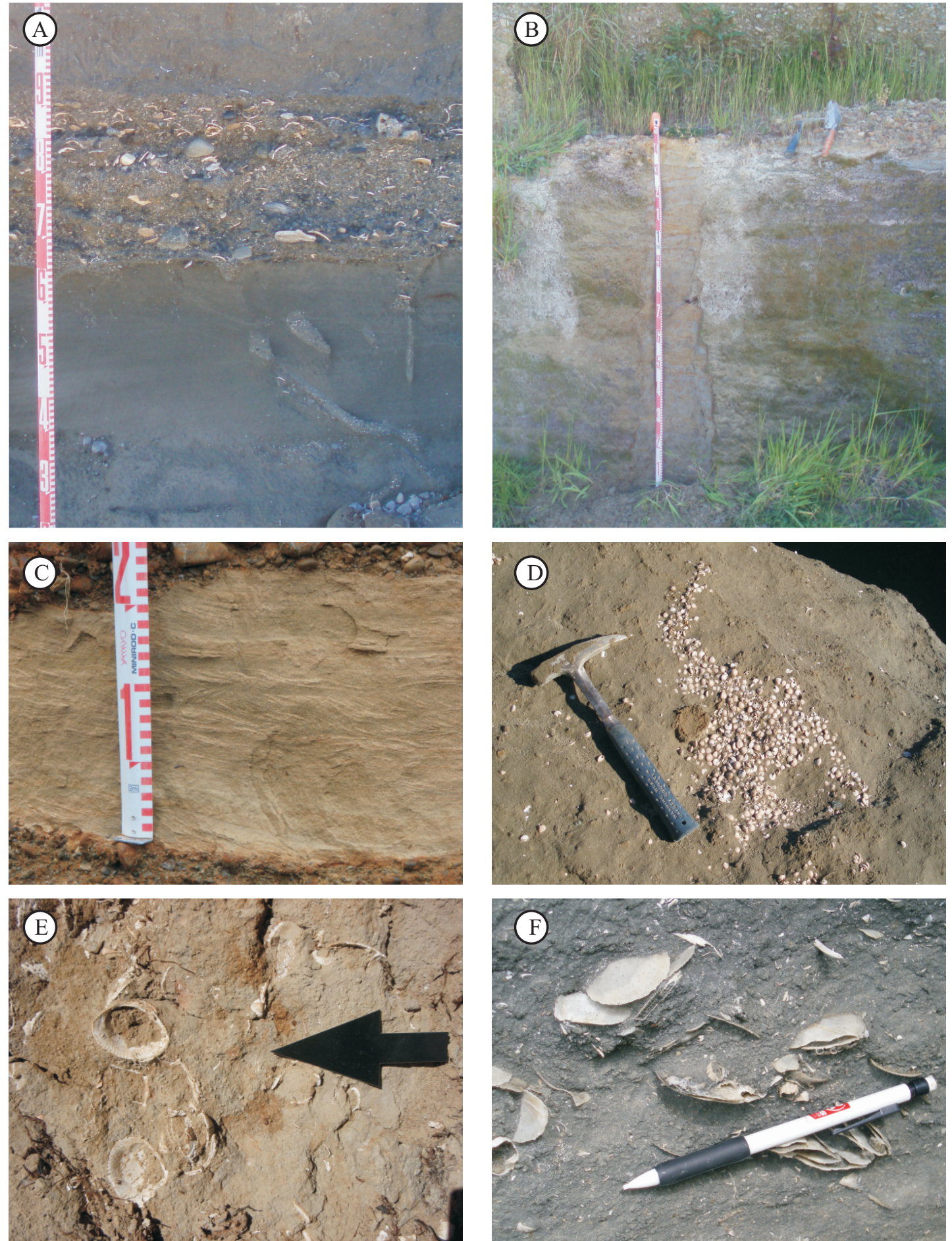

Figure 3.3 A) Profile of the Cs facies, including the highly burrowed lower contact. B) Exposure

of $\mathrm{Sn}$ at the Ruawaka measured section. Note the overlying $\mathrm{Cm}$ facies with a channelised base

near base of trowel. C) Climbing ripples within a minor bed of Sn north of the Hautotara

Formation Type Section (BQ34 072 258). D) The Sw facies at the Ruawaka measured section showing a horizon of Zethalia zelandica. E) Disarticulated Austrovenus stutchburyi within the Sa facies at the Huangarua West measured section. Arrow is $8 \mathrm{~cm}$ long. F) A bed of the Sd facies in the Makara Steam near its confluence with the Ruakokoputuna River (BQ34 073 253). This bed contains a high proportion of the bivalve Talochlamys gemmulata. 


\subsection{Facies $\mathbf{S}$ - Sandstones}

Five sandstone facies are defined in the study area, and are distinguished based on variations in grain size, fossil content and sedimentary structures. Four of the sandstone facies occur only in the Hautotara Formation. Of these, the well-sorted sandstone (Sw), occurs in several of the measured sections, and has the coarsest grain size mode and also often displays cross-bedding and lenses of shell material or greywacke clasts. Sw typically has the gastropod Zethalia zelandica and the bivalve Tawera subsulcata. The Panopea sandstone (Sp), is the finest sandstone of the study area, and often contains Panopea smithae and various forms of burrows. The Dosinia sandstone (Sd) is a commonly planar-bedded fine sandstone, and typically contains high proportions of the bivalves Dosinia subrosea and Talochlamys gemmulata. The Austrovenus sandstone (Sa), is the most poorly-sorted of the sandstone facies, and contains a very distinctive assemblage restricted to Austrovenus stutchburyi, Barytellina crassidens and Zeacumantus lutulentus. The non-fossiliferous sandsone (Sn) is a minor component of the stratigraphy, and the only sandstone facies identified in the Te Muna Formation. Although three of the sandstone facies are named for the dominant genus present, the use of these names is more a practical use of distinguishing between beds in the field and has been retained for ease of identification between the facies.

\subsubsection{Sandstone - Non-fossiliferous (Sn)}

The non-fossiliferous sandstone (Sn) facies is a brown to mottled brown, moderately-firm, rarely planar-bedded to containing climbing ripples, poorly- to moderately well-sorted, medium-to-coarse sandstone (Figures 3.3B, C). The Sn facies contains over $90 \%$ sand, with a coarse $(1.22 \varphi)$ to medium $(0.82 \varphi)$ mode (Figure 3.4). Variations observed include rare thin pockets of dark brown, organicrich mudstones, and rare isolated gravel-sized greywacke clasts, similar to those of the surrounding $\mathbf{C m}$ facies, are observed near the upper contact of some beds. $\mathbf{S n}$ is an uncommon facies in the study area, and is restricted to the Te Muna Formation and younger units. 
The depositional environment of the $\mathbf{S n}$ facies is variable and is interpreted as representing deposition in a variety of non-marine environments, including fluvial channel infill, lateral bars and delta formation within a lacustrine setting. The climbing ripples are comparable to the Sr facies of Browne \& Naish (2003), and are interpreted as the result of sediment deposition in waning flow conditions.

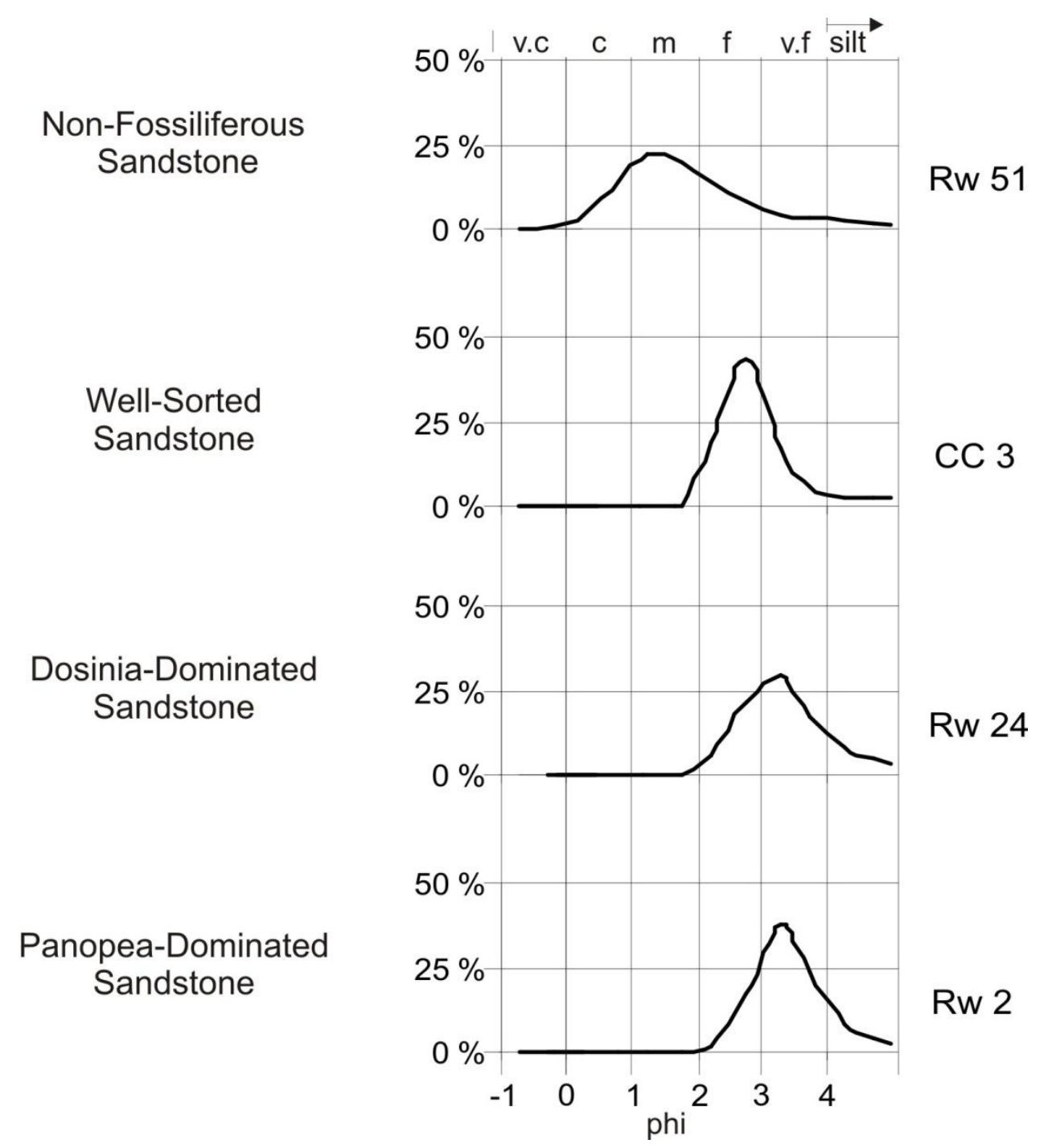

Figure 3.4 Comparison of grain size distribution and sorting between the sandstone facies. Full descriptions of beds can be found using the relevant Unit Names in Appendix Two. 


\subsubsection{Sandstone - Well Sorted (Sw)}

The well-sorted sandstone (Sw) facies is a brown, weakley cemented, occasionally bedded, sparsely-fossiliferous, moderately- to well-sorted fine sandstone. Rare concretionary horizons are observed within the $\mathbf{S w}$ facies. Representative grain size distributions for the $\mathbf{S w}$ facies exhibit a fine sandstone mode $(2.70 \varphi)$ and a fine-tovery-fine mean $(2.98 \varphi)$, with a fine-grained tail (Figure 3.4). Some low-angle trough cross-bedding may be evident through horizons of Zethalia zelandica.

Sw contains moderately-common to rare whole Zethalia zelandica (Figure 3.3D), and rare examples of other shoreface species such as broken clypeasteroids (Fellaster zelandiae), and also whole Tawera subsulcata. Additional minor fossils identified within the $\mathbf{S w}$ facies are worm tubes, a $15 \mathrm{~cm}$ wide unidentified bryozoan colony (Figure A6.1) and whole echinoids - Pseudechinus novaezealandiae. When Sw is well exposed, bioturbation can be observed within the facies, including thin (10 mm) mud-filled burrows, and larger (30 mm wide by $400 \mathrm{~mm}$ long) shell hashfilled burrows.

\section{Depositional Environment}

The $\mathbf{S w}$ facies is inferred as having been deposited in an intertidal-to-subtidal environment, with a beachface-to-shoreface environment the most likely setting. The dominant species of this facies is the gastropod Zethalia zelandica, often found in situ or barely transported. Zethalia zelandica is an extremely common shallow water species, particularly characteristic of the near-shore, sandy beach environment, where in modern environments it lives in water depths of 3-5 metres (Beu \& Maxwell, 1990). This wave-affected intertidal zone is envisaged as being the predominant setting of the $\mathbf{S w}$ facies, with minor depth and energy variations represented by the changes in grain size, sorting, and faunal variations observed. 


\subsubsection{Sandstone - Austrovenus (Sa)}

The Austrovenus sandstone facies (Sa) is a blue-grey to brown, firm, weakly planarbedded, sparsely fossiliferous, muddy-to-gravelly sandstone. Sa is poorly-sorted, and contains two subfacies with distinct variations, where beds grade into organic-rich muds $\left(\mathbf{S a}_{\mathbf{M}}\right)$, or contain cemented-to-firm lenses and channels of granule-to-pebble sized greywacke clasts $\left(\mathbf{S a}_{\mathbf{G}}\right)$.

Sa contains rare weakly-planar bedding observable through sparse fossil layers (Figure 3.3E), or the presence of either subfacies. Fossils are restricted to three species; rare Zeacumantus lutulentus, and randomly orientated shells of the bivalves Austrovenus stutchburyi and Barytellina crassidens. The Sa facies has a maximum thickness of 4 metres. Where the lower contact is observed, it is graded over $4 \mathrm{~cm}$ into the $\mathbf{S w}$ facies.

\section{Subfacies}

Sa contains two distinct subfacies. The mudstone subfacies, $\mathbf{S} \mathbf{a}_{\mathbf{M}}$, consists of organic mud-dominated horizons that often vertically grade with $\mathbf{S a}$, and are typically associated with Zeacumantus lutulentus, while $\mathbf{S a}_{\mathbf{G}}$ is an unfossiliferous conglomeratic subfacies, and contains many variations in composition and the proportions of matrix to clasts. Many of the $\mathbf{S a}_{\mathbf{G}}$ beds have a channelised base into Sa muddy sands.

\section{Depositional Environment}

The primary Sa facies is interpreted to represent deposition in an estuarine setting. The poor sorting of the beds indicates a relatively low-energy environment, while the fossils identified in $\mathbf{S a}_{\mathbf{M}}$ - Austrovenus stutchburyi, Barytellina anomalodonta and Zeacumantus lutulentus - are all estuarine species (Beu \& Maxwell, 1990). Zeacumantus lutulentus is commonly found on intertidal mud flats, and appears to be a good marker for this mud flat setting where observed. Austrovenus stutchburyi is known from a wider range of marginal marine environments, but not fully marine situations, and the characteristics of this species in Sa (i.e. unabraided and relatively 
small) indicates that these specimens have been either preserved in life position within a low saline setting, or transported short distances from one (Beu, 2006).

$\mathbf{S a}_{\mathbf{M}}$ is interpreted as representing a mud flat to a swampy or brackish setting within an estuary, an environment where organic plant matter can accumulate. Subfacies $\mathbf{S a}_{\mathbf{G}}$ is interpreted as consisting of fluvially-derived delta granule-to-cobble sized clasts in an estuarine setting, as channel features into the estuarine sands of $\mathbf{S a}$ facies can be identified. The internal sedimentary structures of the $\mathbf{S a}_{\mathbf{G}}$ are similar to those discussed in $\mathbf{C m}$, further supporting this interpretation.

\subsubsection{Dosinia Sandstone (Sd)}

The Sd facies is a brown to grey, firm, commonly planar-bedded, sparsely fossilised, well-sorted fine sandstone. Representative grain size distribution for the Sd facies exhibit a fine sandstone mean and mode $(2.40 \varphi)$, with a standard deviation of $0.45 \varphi$ (well-sorted) (Figure 3.4). Centimetre-to-decimetre scale planar-bedding is evident through most Sd beds.

Sd contains moderately-common to rare whole Dosinia subrosea, Myadora waitotarana and Talochlamys gemmulata (Figure 3.3F), and rare examples of innerto-mid-shelf species such as Panopea smithae and Amalda mucronata. Additional minor fossils identified within the $\mathbf{S d}$ facies include barnacles, crab chelae and whole echinoids - Pseudechinus novaezealandiae. Rarely, the $\mathbf{S d}$ facies includes fine gravel lenses, comminuted shell sand, and cross-bedding.

\section{Depositional Environment}

The $\mathbf{S d}$ facies is inferred as having been deposited within the shoreface environment. The influence of contrasting energy settings provided by this area can be seen in the planar bedding. The dominant species of this facies, the bivalves Dosinia subrosea and Myadora waitotarana, are often disarticulated, yet unworn. Dosinia subrosea 
and Myadora waitotarana live around low tide off open sandy beaches (Beu \& Maxwell, 1990), correlating with the grain size and bedding data.

\subsubsection{Panopea Sandstone (Sp)}

The $\mathbf{S p}$ facies is a brown to blue-grey, moderately-cemented, largely massive, fossilpoor, bioturbated, moderately-well to poorly-sorted, very fine sandstone. The Sp facies has a very fine sand mode $(3.1 \varphi)$, with a standard deviation between moderately well-sorted and poorly-sorted (0.5 $\varphi$, Figure 3.4$)$. The dominant species of the Sp facies are Panopea smithae preserved in life position, although rare single valves of Tawera subsulcata and Dosinia (Phacosoma) subrosea are also present. A range of burrows are visible within the $\mathbf{S p}$ facies where they consist of a high proportion of fine sand-sized comminuted shell material (Figure 3.5A).

\section{Depositional Environment}

The Sp facies is inferred to represent the inner to mid shelf, and is the deepest depositional setting in the Hautotara Formation. The dominant species is the infaunal bivalve Panopea zelandica, while other species are extremely uncommon, but generally characteristic of an inner- to mid-shelf setting. A mean grain size finer than that of the other open-water sandstone facies indicates that the Sp facies was deposited at a greater depth, and in a calmer setting, than the $\mathbf{S w}$ and $\mathbf{S d}$ facies. This interpretation is reinforced by a lack of current- or tidally-influenced bedding, although this may also be the result of bioturbation. It is inferred that the approximate depositional depth of the Sp facies is between 30 and 50 metres. 


\subsection{Facies SB - Shellbeds}

Four shellbed facies are defined in the study area, and are restricted to the Pukenui Limestone and Hautotara Formation. The limestone (SBI), is a minor component of the Hautotara Formation, but is more common in the underlying Pukenui Limestone. SBI is found at only one section, and is also closely associated with the crossbedded limestone (SBIx) subfacies. The remainder of the shellbeds are interpreted to have all formed within the same water depth as each other, although they have been formed under different conditions, and have varied macrofauna. The Zethalia dominated shellbed (SBz), occurs at a number of sections, and consists of shoreface species, wheras the Tawera dominated shellbed (SBt) contains a slightly deeper marine assemblage. The Austrovenus-Limnoperna dominated shellbed (SBal), contains species from a wide range of environments, from estuarine to inner shelf depths.

The facies are readily differentiated by the macrofauna, however, the named genus need not be present in each bed, and this is particularly true of the SBal facies, where the presence of Limnoperna huttoni requires an appropriate estuarine environment nearby.

\subsubsection{Limestone (SBI)}

The limestone, SBI, is a brown-grey to white, very- to moderately-cemented and recalcified, highly-fossiliferous limestone. The limestone facies is almost entirely comprised of highly condensed, disarticulated Tawera subsulcata, often preserved concave-down, with rare Zethalia zelandica, Dosinia sp. and Ostrea chilensis also observed within the facies. Rare rounded greywacke pebbles have also been observed in several SBI beds.

\section{Subfacies}

The cross-bedded limestone subfacies SBlx is only observed in one section in the Hautotara Formation, and underlies the Hautotara limestone (unit "F" of Rodley, 
1961; Figure 3.5B) SBI bed. The SBlx is an orange-grey cross-bedded shell-hashrich unit, with minor components of fine sands and mud drapes (Figure 3.5C). Species identified in SBIx include Tawera subsulcata, Zethalia zelandica and Dosina zelandica.

\section{Depositional Environment}

The SBI facies is dominated by the extinct bivalve Tawera subsulcata, so the precise environment and depth of the faunal community may only be inferred. The extant Tawera spissa is considered a modern analogue to Tawera subsulcata and is widespread in water depths of 10 to 50 metres along open coastal beaches, although Tawera spissa may be found at depths up to 260 metres (McKnight, 1969). Importantly, Tawera spissa is often found on sands and gravelly sands, the same lithologies identified within and directly below the SBI and SBt (Tawera dominated shellbed) facies.

Fine terriginous sediment is largely absent in the SBI facies, and can be attributed to a number of processes. The major influence is inferred to be either strong tidal forces, sediment starvation of the offshore environment, or a combination of the two. The concave-down, disarticulated character of the shells support the interpretation that tidal flows have played a role in the lack of fine sediment in the SBI facies (Atkins, 1995).

It is inferred that the Tawera subsulcata-dominated SBI limestone facies must be deposited somewhere within 10-50 metres of water depth, consistent with modern accumulations of Tawera (McKnight, 1969). Therefore the approximate water depth the SBI beds were deposited in is estimated to be around 15-25 metres, where tidal influence can still winnow out fine material, but with a water depth comfortably within the living zone of Tawera, where a relative lack of stress would allow sizeable communities to form.

The SBlx subfacies is believed to have been deposited around storm wave base, offshore of a high-energy open beach environment. The shell hash and fractured 

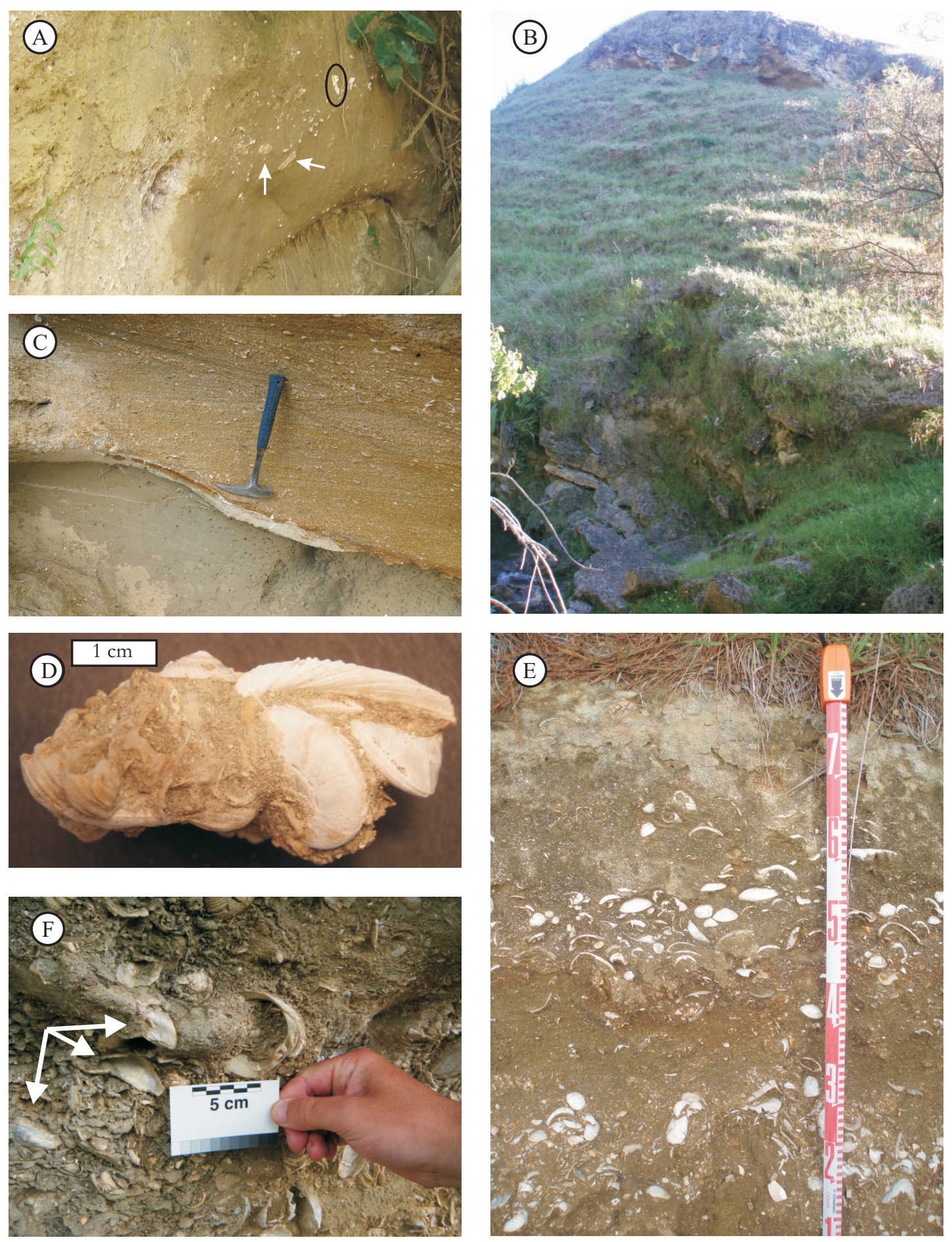

Figure 3.5 A) The Sp facies at the Ruawaka measured section, with Panopea zelandica preserved in life position (circled) and burrows filled with comminuted shellmaterial (arrow). Panopea zelandica is $12 \mathrm{~cm}$ high.B) Pukenui C (base) and Rw6, the "Hautotara limestone" (top), two prominent Sblbeds in the study area. C) The cross-bedded limestone subfacies SBlx, directly below the "Hautotara limestone" SBI bed. D) Collected sample of the SBz facies. Note the unworn nature of the gastropod Zethalia zelandica. E) The SBt facies at the Hinakura Road measured section. F) The SBal facies with estuarine characteristic bivalves Limnoperna huttoni (arrowed) and Austrovenus stutcburyi. 
shallow-water fossils are inferred to have been formed and transported by storm events and deposited in an offshore location, with the cross-bedding formed by alternating tidal or current flows.

Alternatively, the sediment of the SBI and SBIx facies may be a result of production within a "carbonate factory" (Nelson et al., 2003). This setting is a common feature within the Te Aute limestones of the Hawke's Bay, and forms above antiforms (Nelson et al., 2003). This, however, does not change the inferred depth of deposition.

\subsubsection{Zethalia Dominated Shellbed (SBz)}

The SBz facies is a variably coloured, moderately- to well-cemented Zethalia zelandica-dominated shellbed. $\mathbf{S B z}$ consists of randomly orientated, unworn to slightly-worn Z. zelandica and assorted other macrofossils in a medium-fine, poorlysorted matrix with up to $25 \%$ sand-sized comminuted shell fragments (Figure 3.5E).

Although some SBz beds consist of $>85 \%$ Zethalia zelandica, other species found within the shellbed include Fosterella sp., Tawera subsulcata, Zegalerus tenuis and Pseudechinus novaezealandiae. Bed thickness varies between 10 and $30 \mathrm{~cm}$, and both the upper and lower contacts of the facies are gradational to sharp and conformable.

\section{Depositional environment}

The SBz facies is inferred to have been deposited as storm accumulations in the shoreface region just off an open sandy beach. The dominant species within the facies are all shallow-marine, particularly the gastropod Zethalia zelandica, which is commonly found in the modern environment living in 3 to 5 metres of water (Beu \& Maxwell, 1990). The fossils are unworn to slightly-worn and randomly oriented, indicating some transportation has occurred, while the volume of medium-fine sand matrix suggests a level of wave winnowing of the sediments. It is therefore 
interpreted that the $\mathbf{S B z}$ has been deposited at a depth of between 5 and 15 metres, where storm waves may still have an influence on the substrate.

\subsubsection{Tawera Dominated Shellbed (SBt)}

The SBt facies is a brown to blue-grey, moderately-cemented, faintly-bedded shellbed in a sandy matrix (Figure 3.5E). The SBt beds are up to 1 metre thick and largely consist of concave-down Tawera subsulcata, with rare whole-to-fragmented Amalda (Baryspira) depressa, scaphopods and barnacles. The matrix is poorlysorted and consists of fine sands to comminuted shells and rare greywacke granules.

The SBt facies is somewhat analogous to the SBI facies, with the major differences being the proportion of sands and the amount of post-deposition diagenesis that has occurred within each bed. Some variations in faunal content and proportion occur in the SBt facies.

\section{Depositional Environment}

The SBt facies is dominated by the bivalve Tawera subsulcata, although not in as great a proportion in comparison to terriginous sediments as in the SBI facies. Due to the comminuted shells and greywacke granule matrix, it is inferred that the beds of the SBt facies were formed in a generally higher energy environment that of the SBI facies.

It is believed that the SBt facies represents the lower shoreface region, and has been formed in approximately 10-15 metres of water depth, in a region of moderate current and tidal influences. Although this depth is near to the upper limit of the environment that Tawera subsulcata is believed to have lived in - for example, the extant Tawera spissa is widespread in water depths of 10 to 50 metres along open coastal beaches (McKnight, 1969) - it is nevertheless consistent with the data provided. 


\subsubsection{Austrovenus-Limnoperna Dominated Shellbed (SBal)}

The SBal facies is an orange-brown to blue-grey, hard, variably-bedded matrixsupported shellbed, dominated by a mixed-environment faunal assemblage. SBal contains whole and, rarely, articulated fossils in a matrix that varies from poorlysorted sand with greywacke granules to fine sand with mud drapes (Figure 3.5F).

SBal contains numerous fossils from a wide range of environments, but the most conspicuous are the estuarine species prevalent in most beds. Limnoperna huttoni, Austrovenus stutcburyi and Barytellina crassidens are all distinctive species of lowto moderate-salinity environments (Beu \& Maxwell, 1990). Also found within SBal are species such as Tucetonia laticostata, Zethalia zelandica, Myadora waitotarana and Mesopeplum convexum, all of which inhabit a range of different marine environments (Beu \& Maxwell, 1990; Morton \& Miller, 1968).

The shellbeds of the SBal facies are up to $40 \mathrm{~cm}$ thick, with a rapidly gradational lower contact $(2-3 \mathrm{~cm})$, while the upper contact is gradational over $30-40 \mathrm{~cm}$ (Figure 3.6A). The $\mathbf{S B a l}$ facies is surrounded by both the $\mathbf{S p}$ and $\mathbf{S w}$ facies.

Depositional Environment

The SBal facies is inferred to have been deposited rapidly in an inner shelf setting. The shellbeds are accumulations within a marine environment that have largely been transported from an estuarine setting. Limnoperna huttoni and Austrovenus stutcburyi are the dominant species of this facies, and Austrovenus stutcburyi inhabits a range of low salinity environments, while the extinct Limnoperna huttoni is believed to have inhabited brackish lakes and the upper reaches of estuaries (Beu \& Maxwell, 1990). The basis for the transportation of this material from the estuarine setting is believed to be a high energy catastrophic event, such as a flood. As well as the estuarine restricted fauna, species from a range of open water environments, such as Circomphalus parvus, Zethalia zelandica and Austrofusus cottoni are also found in the SBal facies. 
On the top surface of many SBal beds are species such as Tucetonia laticostata and Mesopeplum convexum, which live on gravel and coarse substrate (Beu \& Maxwell, 1990). This indicates post-deposition these particular beds have remained stationary, with little to no sediment influx.
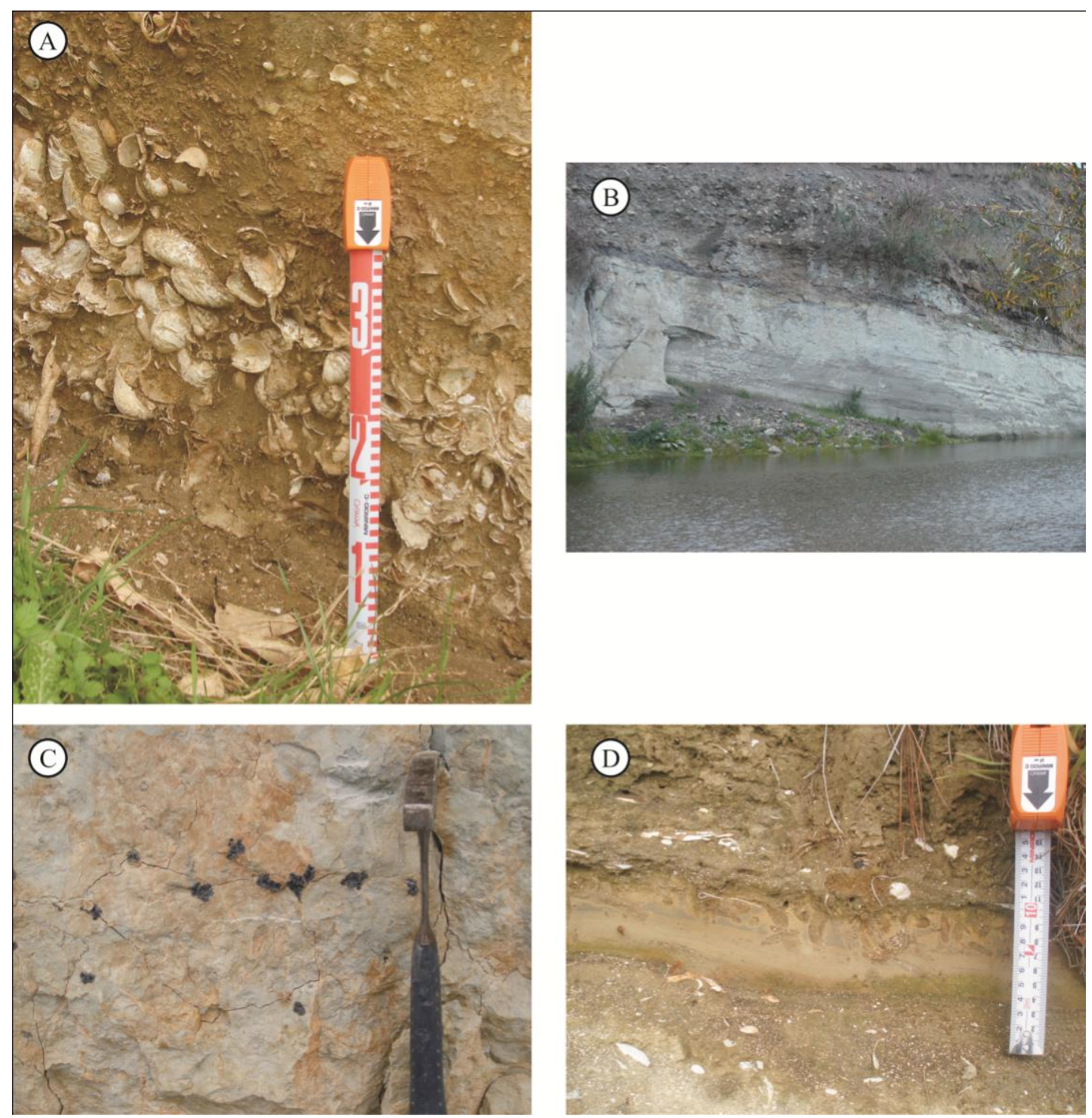

Figure 3.6. A) The SBal facies containing worn and broken shells and exhibiting the rapidly gradational character of the upper contact. B) Laminations visible in the Ms facies at Big Bend. C) Pyrite nodules and yellow jarositic discolouration within the Ms facies at Big Bend (BQ34 079 263). D) HW10 showing fine cross-bedding and bioturbated top contact of the Mc subfacies at the Hinakura Road section (BQ34 145 304). 


\subsection{Facies $\mathbf{M}-$ Mudstones}

The M facies consists of two silt-dominated subfacies. The Sandy Mudstone (Ms) facies is predominately a mudstone, although there are parts of the stratigraphy where it is a muddy sandstone or coarser. The many variations in sediment, grain size and characteristics present within individual Ms beds are here not described as further subfacies, instead, as they represent different energy settings within the same depositional environments, they are kept within the Ms facies. The Cross-bedded Mudstone facies (Mc) is thin, rare and characterised by its poorly sorted grain size and fine cross-laminations.

\subsubsection{Mudstone - Sandy (Ms)}

The sandy mudstone (Ms) facies is a blue-grey to green-grey, firm, massive-tolaminated, barren, very poorly-sorted sandy-mudstone to muddy-sandstone (Figure 3.6B). Some beds contain sandy-to-fine gravel lenses. Although the distribution of the Ms grain size varies, for example, the mode ranges from coarse sand to clay, all beds of the facies are very poorly sorted to poorly sorted (SD 1.5 $2.5 \varphi)$. The Ms appears massive, but weathering allows fine laminations to be observed within some beds. Organic flecks are rarely observed, otherwise, fossils have not been identified in the Ms facies. Rare specimens of Hyridella sp. (fresh water mussels) have previously been noted from equivalent units in the study area (Collen \& Vella, 1984). Laminated beds of Ms at Big Bend also contain pyrite nodules and jarositic staining (Figure 3.6C).

Ms beds are up to six metres thick within the measured sections, but are thicker in the Big Bend area, and up to 20 metres thick at the type section (Collen \& Vella, 1984). Ms predominately overlies $\mathbf{C m}$ beds above a conformable, planar contact, although occasionally the Ms is interbedded with an organic $(\mathbf{O})$ or tephra $(\mathbf{V})$ bed. Ms is often overlain by $\mathbf{C m}$ with an erosional, channelised-to-planar contact. 


\section{Depositional Environment}

The lack of marine fossils, the stratigraphic relationships of Ms with inferred terrestrial deposits, and the previously-identified freshwater Hyridella sp. fossils (Collen \& Vella, 1984), indicate a non-marine setting for the deposition of Ms. Thin laminations present at some locations indicate a slow, relatively low-energy lacustrine environment away from high sedimentation sources such as river mouths. The occurrence of pyrite and yellow jarositic discolouration also implies that the setting was quiet, as pyrite develops in an anoxic setting, suggesting that limited mixing of the water occurred in the lakes. Sandy-to-fine gravel deposits observed within Ms are inferred as relating to migrating river mouth or delta settings. Variations of the grain size of Ms are similar to those observed by Woolfe (1993, 1995) and Pickrill \& Irving (1978), and are discussed in detail in Chapter 5.

Rataul (1988) assessed the clay mineralogy of the equivalent facies at the type section, where a freshwater clay mineral assemblage was identified, based on the presence of high kaolinite, low chloride, and mixed-layer clays.

The Ms beds are inferred as having been deposited in a lacustrine setting similar to that of the modern day Lake Wairarapa. The Quaternary lacustrine deposits of the Wairarapa Valley are believed to have formed under the same conditions as the modern Lake Wairarapa, that is, within a highstand period. The processes currently controlling the sedimentation within the valley are similar to those expected in the past, that is, localised uplift and subsidence, higher river base levels and lower gradients, and large gravel beach barrier systems closing the valley from the open ocean.

\subsubsection{Mudstone - Cross-Bedded (Mc)}

The cross-bedded mudstone (Mc) facies is a brown, to white, to dark-grey, moderately-firm, bioturbated, thinly bedded to laminated sandy mudstone (Figure 3.6D). Mc is lacking in macrofossils, and contains extensive burrows up to $5 \mathrm{~mm}$ wide and $4 \mathrm{~cm}$ deep, filled with sediment from the overlying sandstone facies. Faint 
cross-bedding is observed. Mc is poorly sorted, with at least $60 \%$ silt and less than $5 \%$ clays.

\section{Depositional Environment}

The Mc facies is analogous to the muds of the "Interbedded mud and sand beds" of Rampton (1997) within the Pukenui Limestone, stratigraphically below this study's Hinakura Road measured section. Within this unit, Rampton identified a "very shallow, almost estuarine" foraminiferal assemblage. It is proposed that the Mc facies represents a sheltered marine setting, with the deposition controlled by lowenergy traction currents, with the cross-bedded mudstone probably influenced by tidal motion.

The Mc facies is interpreted as representing a tidally-influenced back-barrier lagoon, landward of the $\mathbf{S w}$ facies. 


\subsection{Facies V - Volcaniclastic}

The $\mathbf{V}$ facies is a variable assortment of largely weathered rhyolitic ash identified in the Te Muna and Hautotara formations of the study area. The approach taken to describe the $\mathbf{V}$ facies differs from the rest of this chapter. Here, each individual bed will be examined in an attempt to identify the depositional controls, and an examination of the major element data will provide correlatives, both between sections and previously studied deposits of the field area, and also tephra identified in the Wanganui Basin and Ocean Drilling Programme (ODP) cores recovered of the east coast of the North Island (e.g. Pillans et al., 2005).

This study has sampled ten discreet tephra beds from the area, although preparation for geochemical analysis reveals that four of these beds have been completely weathered to clay, inhibiting major element correlation to other deposits.

A summary of the location, and state, of each tephra is provided in Table 3.2. The locations of all known Hautotara and Te Muna formation tephra found in the study area are shown in Figure 3.7.

\begin{tabular}{|c|c|c|c|}
\hline Tephra & $\begin{array}{c}\text { Code } \\
\text { (this study) }\end{array}$ & Grid Reference & $\begin{array}{c}\text { State of } \\
\text { Preservation }\end{array}$ \\
\hline Ruawaka & RwT & BQ34 085 267 & Weathered to clay \\
\hline Hinakura Road Lower & HR1 & BQ34 144 304 & Well Preserved \\
\hline Hinakura Road Upper & HRu & BQ34 144 305 & Well Preserved \\
\hline Lower Popes Head & LPH & BQ34 145 306 & Weathered to clay \\
\hline Upper Popes Head & UPH & BQ34 145 305 & Weathered to clay \\
\hline Duggan Ash & DA & BQ33 028 231 & Weathered to clay \\
\hline Huangarua-lower & HW1 & BQ34 089 303 & Well Preserved \\
\hline Huangarua-upper & HWu & BQ34 094 303 & Well Preserved \\
\hline Lower Te Muna & LTM & BQ34 089 276 & Well Preserved \\
\hline Upper Te Muna & UTM & BQ34 089 276 & Well Preserved \\
\hline
\end{tabular}

Table 3.2 Tephra of the Hautotara and Te Muna formations in this study. 


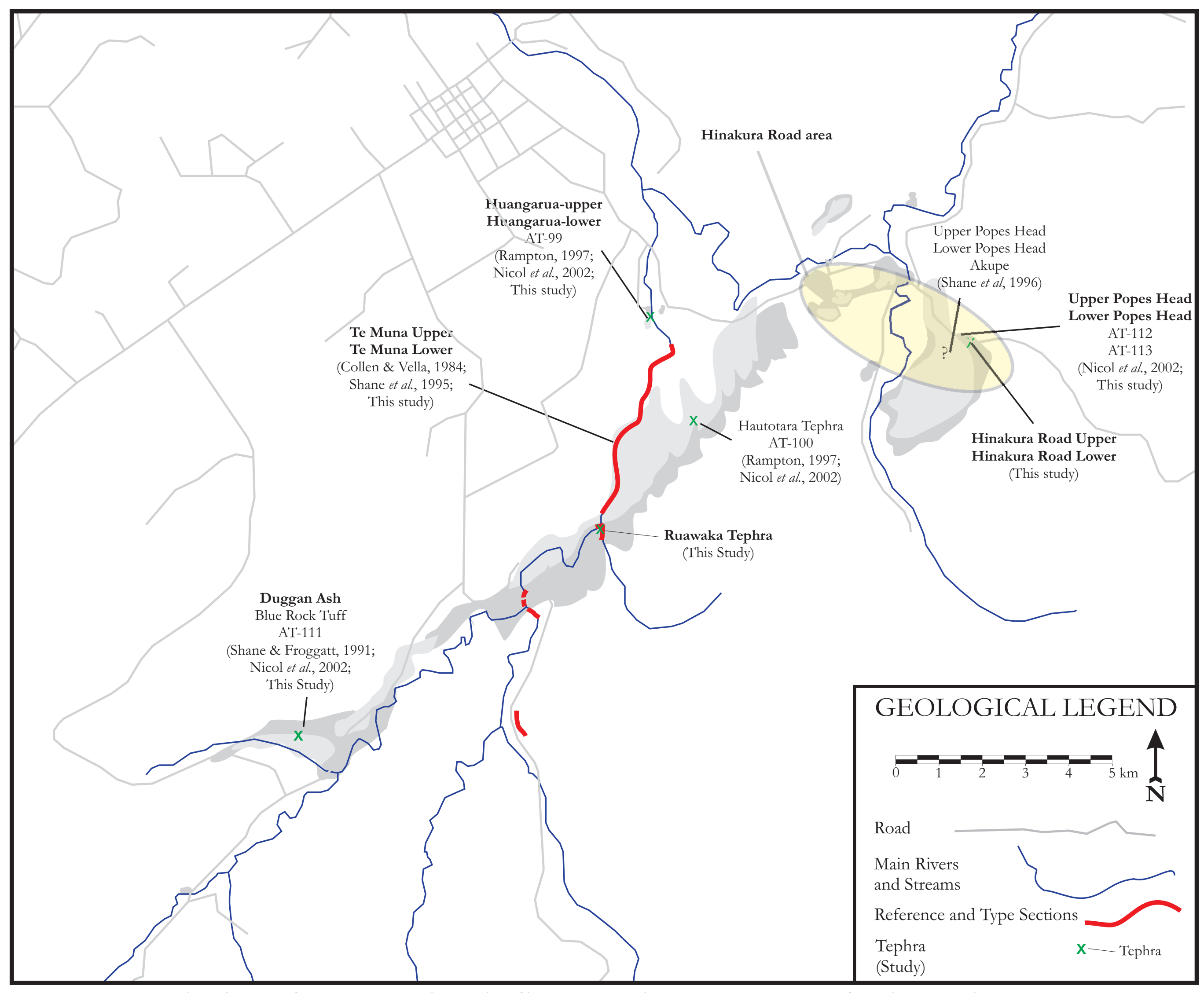

Figure 3.7. Map of the study area showing location of important tephra in the Hautotara and Te Muna formations. Names in bold preferred name as used in this study. Tephra of the Hinakura Road area are chemically indistinguishable, and often referred to as a package. Note studies highlighted are representative only and not a complete list. 
Hinakura Road Lower \& Upper Tephra (This study) also Upper \& Lower Popes Head Tephra (O’Brien, 1980), Akupe Tephra (Shane \& Froggatt, 1991)

Geochemically correlative to the Upper and Lower Popes Head, and Akupe Tephra (Table 3.3; Figures 3.8,10-11; Nicol, et al., 2002), these two deposits appear to have been deposited in a different environment than those found to the immediate northwest (Figure 3.7), and are potentially distinct deposits (e.g. O’Brien, 1980).

\begin{tabular}{|c|c|c|c|c|c|c|c|c|c|c|c|}
\hline Sample/Study & $\mathrm{SiO}_{2}$ & $\mathrm{Al}_{2} \mathrm{O}_{3}$ & $\mathrm{TiO} 2$ & $\mathrm{FeO}$ & $\mathrm{MgO}$ & $\mathrm{CaO}$ & $\mathrm{Na}_{2} \mathrm{O}$ & $\mathrm{K}_{2} \mathrm{O}$ & $\mathrm{MnO}$ & water & $n$ \\
\hline \multicolumn{12}{|l|}{ Hinakura Road Upper } \\
\hline \multirow[t]{2}{*}{ Tephra } & 74.38 & 13.76 & 0.16 & 2.01 & 0.11 & 1.05 & 4.87 & 3.59 & 0.06 & 6.07 & 19 \\
\hline & 0.18 & 0.07 & 0.02 & 0.10 & 0.01 & 0.03 & 0.15 & 0.10 & 0.03 & 0.64 & \\
\hline \multicolumn{12}{|l|}{ Hinakura Road Lower } \\
\hline \multirow[t]{2}{*}{ Tephra } & 74.63 & 13.66 & 0.17 & 2.05 & 0.11 & 1.04 & 4.71 & 3.57 & 0.07 & 5.98 & 15 \\
\hline & 0.21 & 0.11 & 0.02 & 0.08 & 0.01 & 0.02 & 0.22 & 0.20 & 0.02 & 0.59 & \\
\hline Upper Popes Head & 75.27 & 13.56 & 0.17 & 2.07 & 0.12 & 1.06 & 4.16 & 3.59 & - & 4.92 & 9 \\
\hline (Shane \& Froggatt 1991) & 0.20 & 0.09 & 0.03 & 0.09 & 0.03 & 0.04 & 0.29 & 0.36 & & 0.88 & \\
\hline Lower Popes Head & 75.42 & 13.51 & 0.17 & 2.15 & 0.12 & 1.05 & 4.03 & 3.56 & - & 5.23 & 9 \\
\hline (Shane \& Froggatt 1991) & 0.33 & 0.23 & 0.02 & 0.08 & 0.01 & 0.04 & 0.38 & 0.20 & & 1.00 & \\
\hline Akupe & 75.74 & 13.59 & 0.14 & 2.03 & 0.12 & 1.05 & 3.94 & 3.39 & - & 5.53 & 10 \\
\hline (Shane \& Froggatt 1991) & 0.57 & 0.13 & 0.03 & 0.09 & 0.02 & 0.06 & 0.55 & 0.21 & & 0.82 & \\
\hline AT-112 & 74.71 & 13.27 & 0.19 & 2.18 & 0.12 & 1.11 & 4.73 & 3.54 & - & 5.08 & 12 \\
\hline (Nicol et al., 2002) & 0.19 & 0.14 & 0.08 & 0.07 & 0.02 & 0.05 & 0.06 & 0.09 & & 0.49 & \\
\hline AT-113 & 74.60 & 13.42 & 0.17 & 2.14 & 0.11 & 1.12 & 4.78 & 3.50 & - & 4.88 & 12 \\
\hline (Nicol et al., 2002) & 0.23 & 0.13 & 0.03 & 0.03 & 0.02 & 0.03 & 0.10 & 0.14 & & 0.59 & \\
\hline Oyster & 74.60 & 13.95 & 0.19 & 2.18 & 0.16 & 1.10 & 3.96 & 3.74 & - & 7.50 & 11 \\
\hline (Rampton 1997) & 0.53 & 0.41 & 0.05 & 0.15 & 0.05 & 0.05 & 0.20 & 0.17 & & 1.44 & \\
\hline \multicolumn{12}{|l|}{ Correlatives } \\
\hline Maranoa Tephra (AT-359) & 75.13 & 13.45 & 0.16 & 1.99 & 0.11 & 1.00 & 4.05 & 3.95 & - & 5.06 & 14 \\
\hline (Pillans et al., 2005) & 0.35 & 0.17 & 0.07 & 0.17 & 0.04 & 0.08 & 0.21 & 0.33 & & 0.60 & \\
\hline Ridge Tephra (AT-293) & 74.88 & 13.77 & 0.19 & 2.12 & 0.14 & 0.98 & 3.94 & 3.77 & - & 5.38 & 10 \\
\hline (Pillans et al., 2005) & 0.42 & 0.33 & 0.04 & 0.19 & 0.04 & 0.09 & 0.20 & 0.09 & & 1.30 & \\
\hline Birdgrove Tephra (BP-548) & 74.41 & 13.40 & 0.21 & 2.09 & 0.17 & 1.14 & 4.40 & 3.94 & - & 6.77 & 9 \\
\hline (Pillans et al., 2005) & 0.53 & 0.27 & 0.05 & 0.27 & 0.06 & 0.12 & 0.24 & 0.28 & & 1.14 & \\
\hline AT-382 (ODP Core 1123) & 74.60 & 13.60 & 0.20 & 2.07 & 0.12 & 1.08 & 4.25 & 3.73 & 0.11 & 8.84 & 17 \\
\hline (Allan 2008) & 0.32 & 0.18 & 0.40 & 0.14 & 0.30 & 0.80 & 0.25 & 0.16 & 0.60 & 1.16 & \\
\hline AT-383 (ODP Core 1123) & 74.80 & 13.60 & 0.19 & 2.03 & 0.11 & 0.97 & 4.56 & 3.50 & 0.12 & 5.04 & 18 \\
\hline (Allan 2008) & 0.53 & 0.43 & 0.08 & 0.28 & 0.04 & 0.16 & 0.39 & 0.20 & 0.16 & 2.09 & \\
\hline AT-407 (ODP Core 1123) & 75.20 & 13.40 & 0.17 & 2.11 & 0.11 & 1.01 & 4.22 & 3.55 & 0.12 & 6.12 & 17 \\
\hline (Allan 2008) & 0.85 & 0.53 & 0.08 & 0.43 & 0.04 & 0.18 & 0.72 & 1.11 & 0.10 & 2.24 & \\
\hline
\end{tabular}

Table 3.3. Glass composition of tephra in the Hinakura Road area and correlatives from the Wanganui Basin and ODP Cores. All elements calculated on a water-free basis, with water by difference from $100 \%$. All Fe expressed as FeO. Mean and one standard deviation (in italics) based on $\boldsymbol{n}$ analysis. Further details provided in Appendix Four. 
Major element analysis indicates the Hinakura Road Lower Tephra is from a single event (Figure 3.8). The Hinakura Road Lower Tephra is mottled yellow to white, sometimes pink, massive rhyolitic ash deposit sharply overlying a lacustrine mudstone (Figure 3.9C,D). It is bioturbated from above, while a $10 \mathrm{~cm}$ thick organic horizon directly overlying this bed could signify at least a partial disturbance of the local vegetation as a result of the emplacement event, or possibly the presence of a swamp (Bussell \& Pillans, 1992).
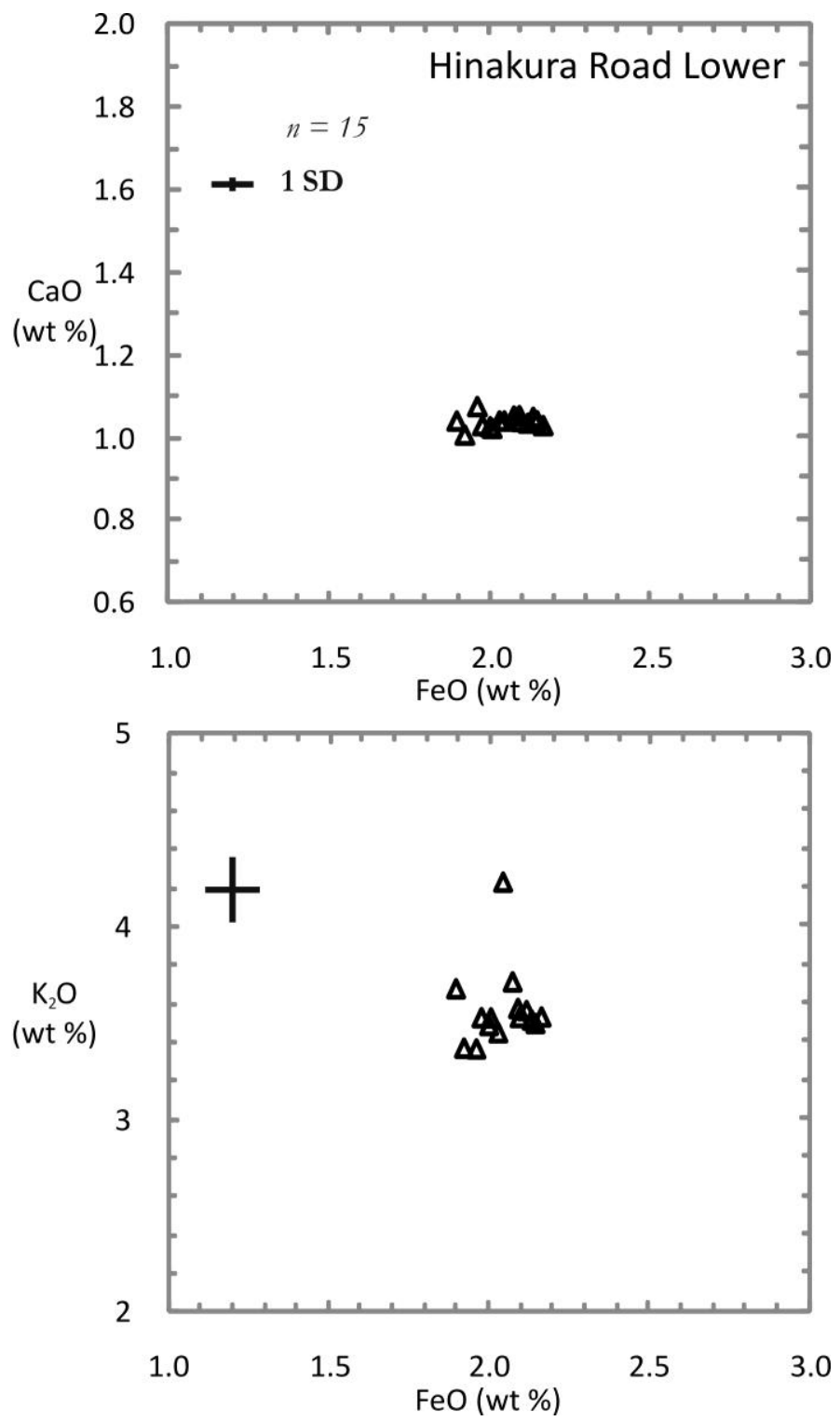

Figure 3.8. Plots of $\mathrm{CaO}$ versus $\mathrm{FeO}$ (top) and $\mathrm{K}_{2} \mathrm{O}$ versus $\mathrm{FeO}$ (base) for the Hinakura $\mathrm{Road}$ Lower Tephra. See Table 3.3 and Appendix Four for details. $\boldsymbol{n}$ is the number of analysis run, bars are one standard deviation. 

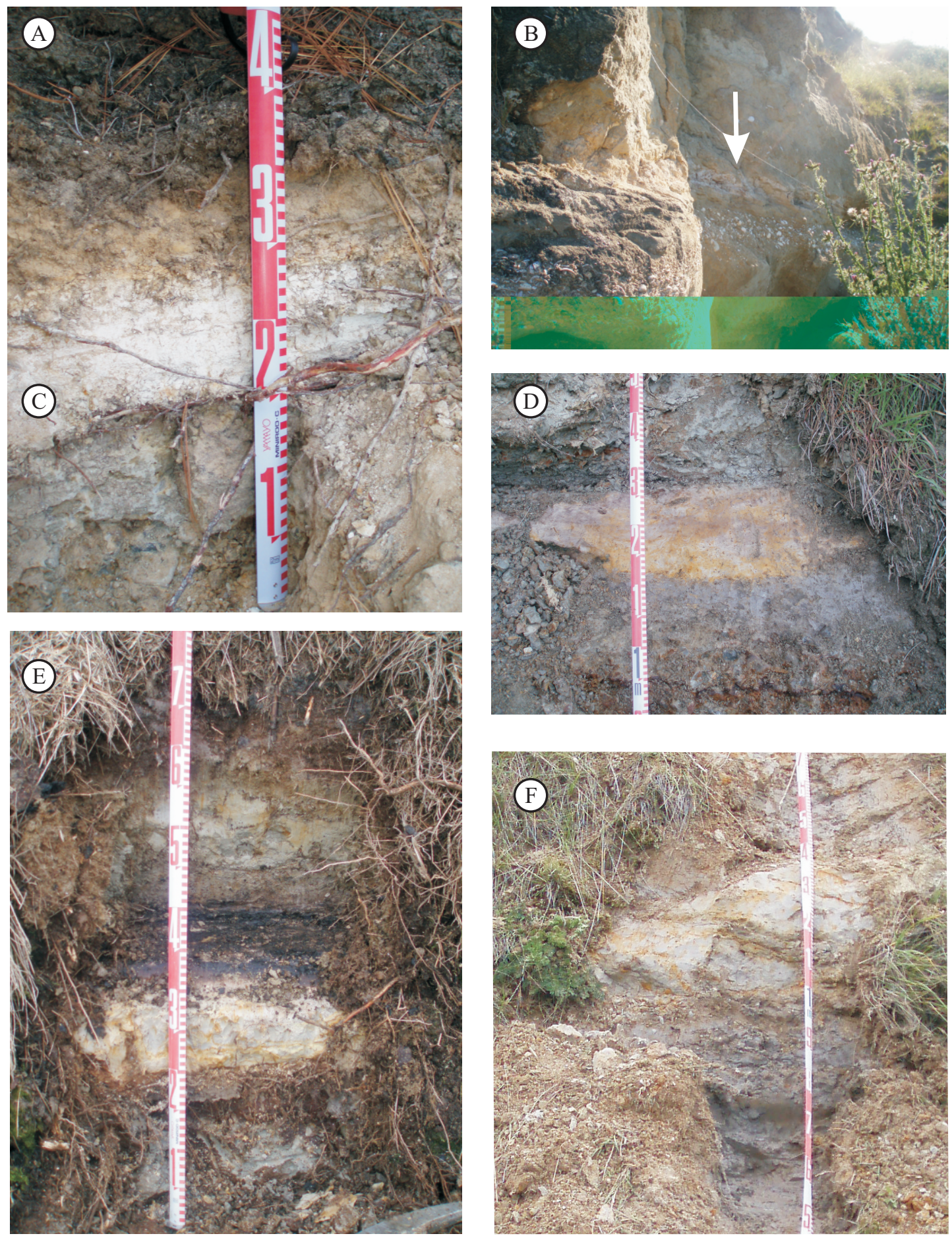

Figure 3.9 A) Lower Popes Head Tephra, weathered to clay. B) Weathered tephra (arrowed) identified in marginal marine facies at the Ruawaka measured section. C, D) Yellow to pink, massive Hinakura Road Lower Tephra near the base of the lacustrine mudstone overlying the lowermost conglomerate if the Te Muna Formation. Note variation in lignite levels between exposures. E) Hinakura Road Upper Tephra, overlain by laminated sandstones. 
The Hinakura Road Upper Tephra is a white to light grey, massive rhyolitic ash deposit with some sulphur staining (Figure 3.9E). The lower contact is sharp and wavy over $1 \mathrm{~cm}$. No organic material is observed above or below this tephra. Major element analysis supports the interpretation that this deposit is from a single event (Figure 3.10).
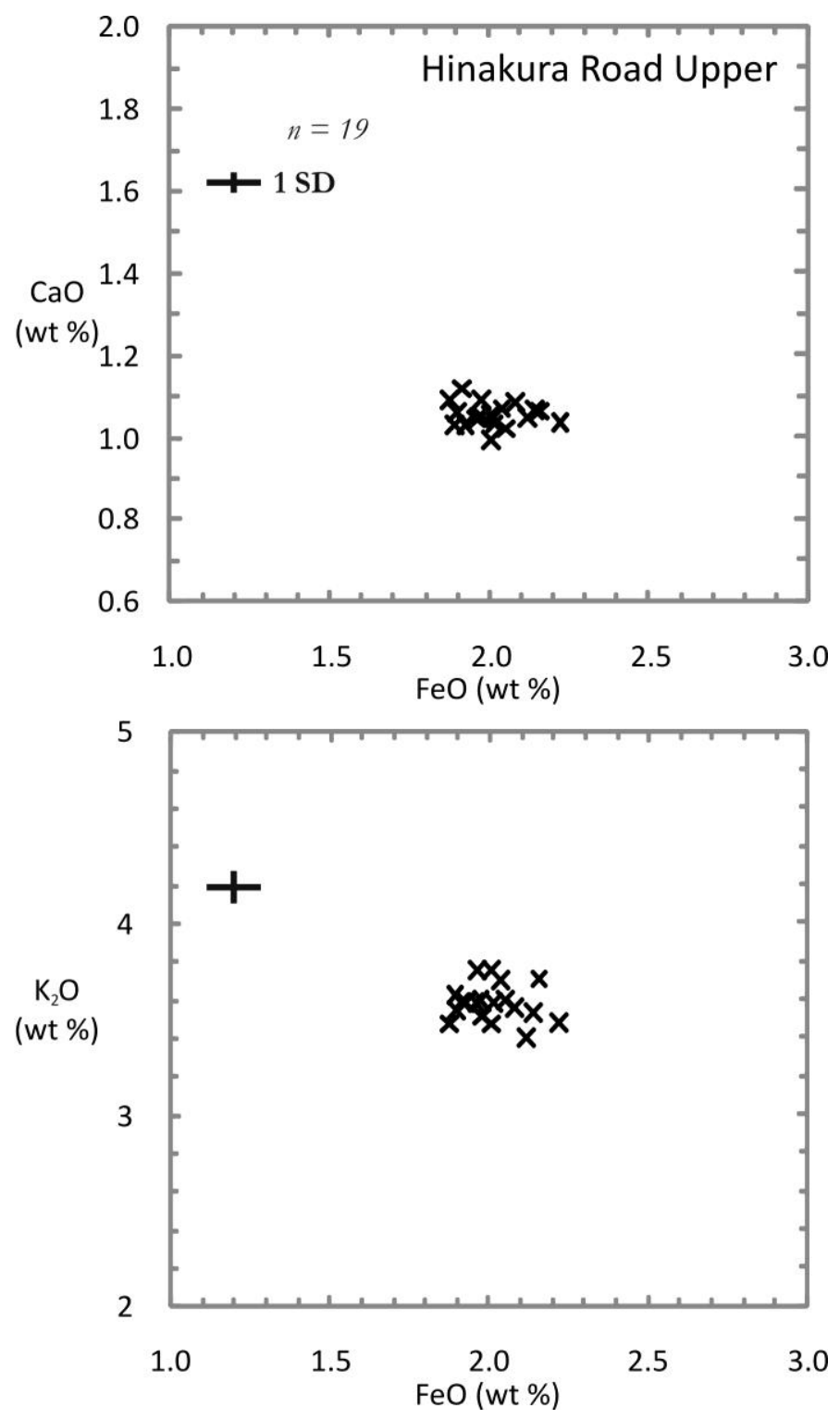

Figure 3.10. Plots of $\mathrm{CaO}$ versus $\mathrm{FeO}$ (top) and $\mathrm{K}_{2} \mathrm{O}$ versus $\mathrm{FeO}$ (base) for the Hinakura $\mathrm{Road}$ Upper Tephra. See Table 3.3 and Appendix Four for details. $n$ is the number of analysis run, bars are one standard deviation. 
A near continuous exposure at the top of the Hinakura Road Measured Section (Figure 2.6A) shows the Hinakura Road Upper and Lower Tephra are separated by 4.5 metres of stratigraphy, including two metres of conglomerate near the base of the Te Muna Formation (Appendix Two). These tephra do not appear to merge along strike, as has been suggested for the Upper and Lower Popes Head and Akupe Tephra to the north-west (Figure 3.7; Shane \& Froggatt, 1991).

Major element analysis show the tephra of the Hinakura Road area (Figure 3.7) are correlative to a number of tephra surrounding the Pakihikura Tephra in the Wanganui Basin, and identified in ODP cores. In particular the Ridge (1.56 Ma), Maranoa (1.63 Ma) and Birdgrove (1.60 Ma - all astronomically tuned) are indistinguishable from the tephra of the study area (Table 3.3; Figure 3.12 (Pillans et $a l$,. 2005). This agrees well with previous analysis of the Akupe Tephra, which is assigned an Isothermal plateau fission-track (ITPFT) age of $1.64 \pm 0.16 \mathrm{Ma}$ (Shane et al., 1996).

Three tephra of the ODP Core 1123 also appear to be correlatives with the tephra of the Hinakura Road area. Samples AT-382, AT-383 and AT-407 appear chemically indistinguishable from the tephra in the Hinakura Road area (Figure 3.12). A reinterpretation of the stratigraphy of the ODP Core 1123 has provided orbitally tuned stable isotope ages of $1.532 \mathrm{Ma}$ (AT-407), $1.566 \mathrm{Ma}$ (AT-382) and $1.584 \mathrm{Ma}$ (AT-383), comparable to the $1.64 \pm 0.16$ ITPFT age of the Akupe Tephra in the field area (Shane et al., 1996; Allan et al., 2008).

Due to the major element chemistry of tephra in the Hinakura Road region, and possibly their close proximity to one another, past studies have inferred that these tephra have come from a single event and the multiple beds are due to reworking (Shane \& Froggatt, 1991). Here the analysis place these Hinakura Road tephra within a timeframe over which numerous chemically indistinguishable eruptive events have occurred, and it is interpreted that these tephra have been emplaced over more than one Milankovitch scale cycle. 


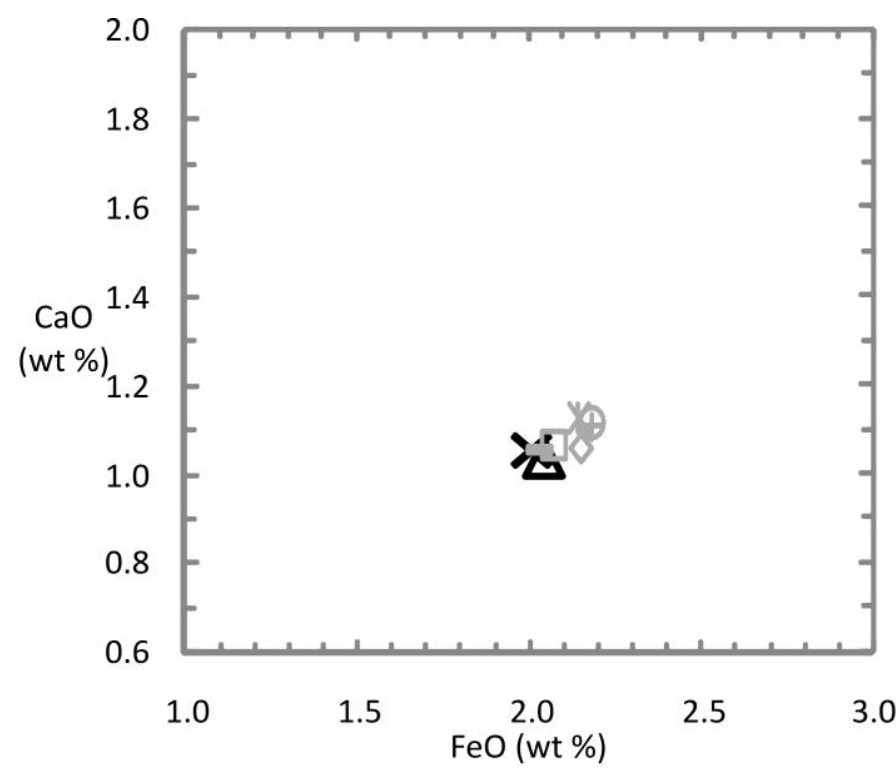

$\Delta$ Hinakura Road Lower Tephra

X Hinakura Road Upper Tephra

Upper Popes Head

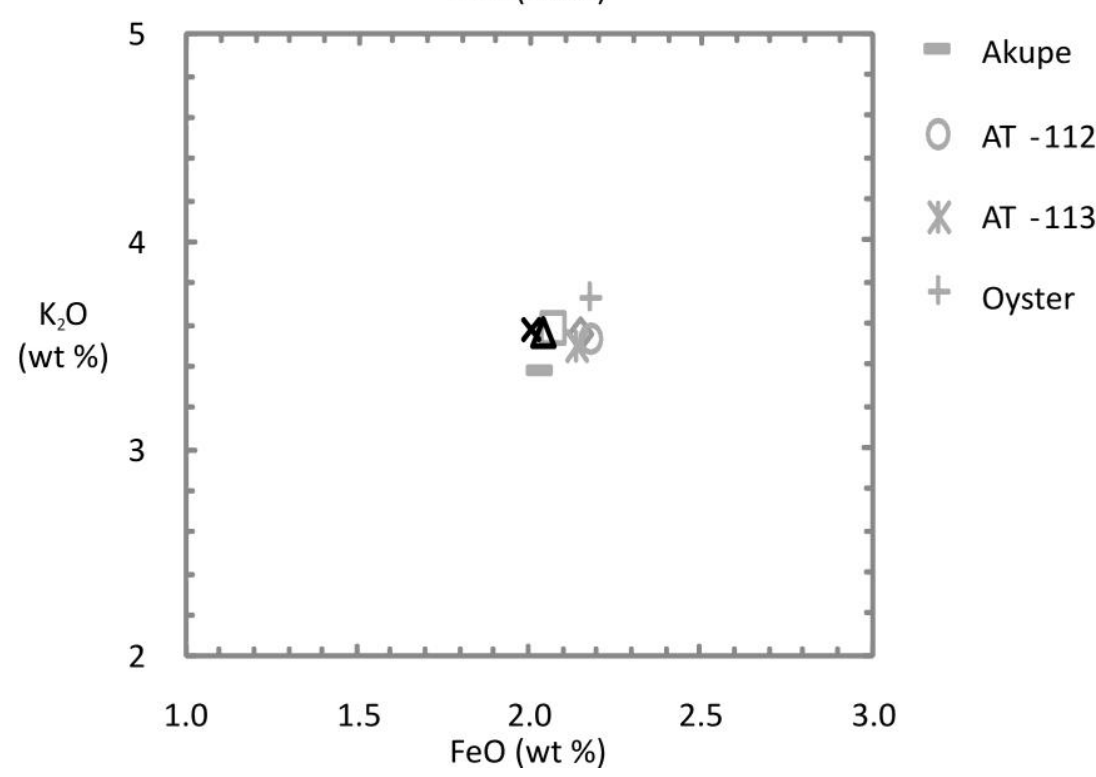

Figure 3.11. Plots of $\mathrm{CaO}$ versus $\mathrm{FeO}$ (top) and $\mathrm{K}_{2} \mathrm{O}$ versus $\mathrm{FeO}$ (base) for the Hinakura $\mathrm{Road}$ Upper and Lower Tephra with their correlatives from this region. See Table 3.3 for details.

Two deposits here identified as the Lower and Upper Popes Head Tephra (Figure 3.7) are exposed in road cuttings on the northern side of Hinakura Road. Both the Lower and Upper Popes Head Tephra are up to $10 \mathrm{~cm}$ thick with a planar lower contact, and have been weathered to white clay (Figure 3.9A). As a consequence, no geochemical analysis has been undertaken on these deposits in this study. These two tephra also lack stratigraphic control, although significantly, in contrast to the nearby Hinakura Road Lower Tephra, the Lower Popes Head Tephra was not overlain by organic or lignite deposits. 


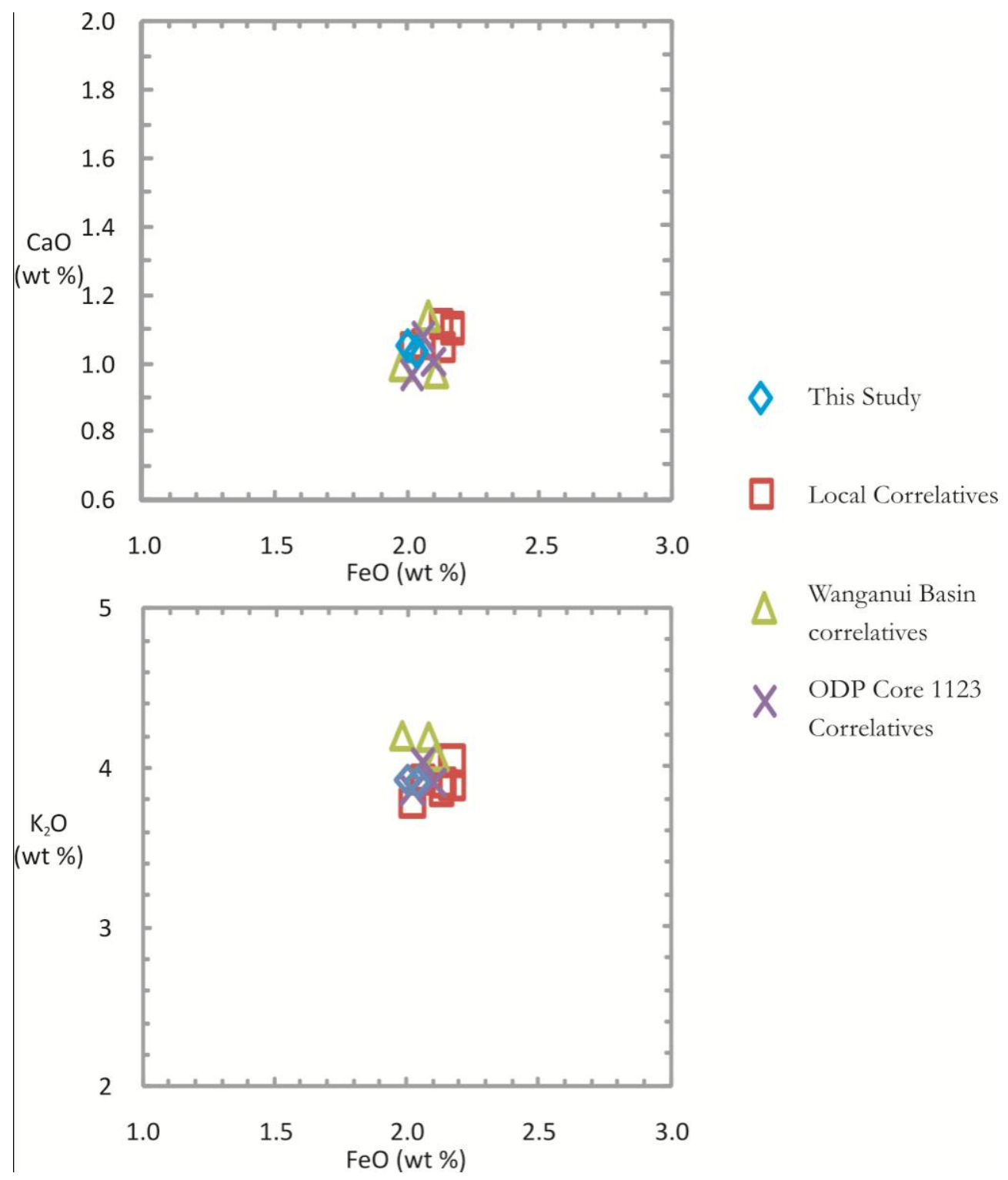

Figure 3.12. Plots of $\mathrm{CaO}$ versus $\mathrm{FeO}$ (top) and $\mathrm{K}_{2} \mathrm{O}$ versus $\mathrm{FeO}$ (base) for tephra of the Hinakura Road area and their correlatives from the Wanganui Basin and ODP Core 1123. See Table 3.3 for details.

Duggan Ash (Thomson, 1980), Blue Rock Tuff (Shane \& Froggatt, 1991)

First described by Thomson (1980), this one metre thick deposit is situated in the Te Muna Formation overlying the Blue Rock Hautotara Measured Section (Figure 3.7). Outcrops of the Duggan Ash sampled for this study were weathered to clay, inhibiting geochemical analysis. Nicol et al, (2002), note that the chemistry of the Duggan Ash (AT-111) is similar to AT-112 and AT-113, collected from the Hinakura Road area (Figure 3.7), and here it is interpreted to be from the same series of eruptive events as the tephra of the Hinakura Road area. 


\section{Ruawaka Tephra (This Study)}

This highly weathered deposit is identified within a Sd facies bed of the Hautotara Formation in the Ruawaka Measured Section (Figure 3.9B). No glass was recovered from this deposit, and no bedding is discernable. This tephra has not previously been described, but may be correlative to the Hautotara Tephra identified by Rampton (1997) in an estuarine environment to the north of this section (Figure 3.7).

Huangarua-lower (Rampton, 1997)

The Huangarua-lower Tephra is a $13 \mathrm{~cm}$ white, massive, fine pumiceous ash deposit in the lowermost lacustrine unit of the Te Muna Formation, 1.5 metres below the Huangarua-upper Tephra at the Huangarua West Measured Section (Figure 3.13B,D; Appendix Two). The Huangarua-lower Tephra has a conformable planar lower contact and is also bioturbated to a depth of five $\mathrm{cm}$ from the overlying unit.

A strong cluster and low standard deviation in the major element plot is consistent with the Huangarua-lower Tephra being derived from a single source (Table 3.4; Figure 3.14).

\begin{tabular}{|c|c|c|c|c|c|c|c|c|c|c|c|}
\hline Sample/Study & $\mathrm{SiO}_{2}$ & $\mathrm{Al}_{2} \mathrm{O}_{3}$ & $\mathrm{TiO} 2$ & $\mathrm{FeO}$ & $\mathrm{MgO}$ & $\mathrm{CaO}$ & $\mathrm{Na}_{2} \mathrm{O}$ & $\mathrm{K}_{2} \mathrm{O}$ & $\mathrm{MnO}$ & water & $n$ \\
\hline Huangarua-lower & 75.89 & 13.22 & 0.11 & 1.67 & 0.07 & 0.94 & 4.58 & 3.48 & 0.05 & 6.61 & 18 \\
\hline (This study) & 0.19 & 0.14 & 0.02 & 0.10 & 0.01 & 0.02 & 0.10 & 0.08 & 0.02 & 0.74 & \\
\hline \multicolumn{12}{|l|}{ Local Correlatives } \\
\hline Huangarua-lower & 76.46 & 12.73 & 0.13 & 1.8 & 0.12 & 0.91 & 3.9 & 3.94 & - & 6.58 & 12 \\
\hline (Rampton 1997) & 0.33 & 0.28 & 0.04 & 0.15 & 0.04 & 0.06 & 0.13 & 0.14 & & 0.81 & \\
\hline AT-99 & 76.31 & 12.76 & 0.10 & 1.70 & 0.07 & 0.99 & 4.44 & 3.47 & - & 5.15 & 12 \\
\hline (Nicol et al., 2002) & 0.13 & 0.16 & 0.05 & 0.06 & 0.01 & 0.05 & 0.12 & 0.11 & & 0.34 & \\
\hline AT-114 & 76.13 & 12.83 & 0.1 & 1.74 & 0.07 & 1 & 4.47 & 3.53 & - & 4.7 & 12 \\
\hline (Nicol et al., 2002) & 0.12 & 0.1 & 0.06 & 0.04 & 0.02 & 0.05 & 0.11 & 0.1 & & 0.35 & \\
\hline \multicolumn{12}{|l|}{ Correlatives } \\
\hline AT-405 (ODP Core 1123) & 75.6 & 13.7 & 0.15 & 1.57 & 0.21 & 0.97 & 4.02 & 3.49 & 0.08 & 2.65 & 11 \\
\hline (Allan 2008) & 1.34 & 0.91 & 0.13 & 0.3 & 0.61 & 0.11 & 1.11 & 0.26 & 0.14 & 2.3 & \\
\hline \multicolumn{12}{|l|}{ For Comparison } \\
\hline Manaroa Tephra (AT-359) & 75.13 & 13.45 & 0.16 & 1.99 & 0.11 & 1.00 & 4.05 & 3.95 & - & 5.06 & 14 \\
\hline (Pillans et al., 2005) & 0.35 & 0.17 & 0.07 & 0.17 & 0.04 & 0.08 & 0.21 & 0.33 & & 0.60 & \\
\hline
\end{tabular}

Table 3.4. Glass composition of the Huangarua-lower Tephra and correlatives. All elements calculated on a water-free basis, with water by difference from $100 \%$. All Fe expressed as FeO. Mean and one standard deviation (in italics) based on $\boldsymbol{n}$ analysis. Further details provided in Appendix Four. 

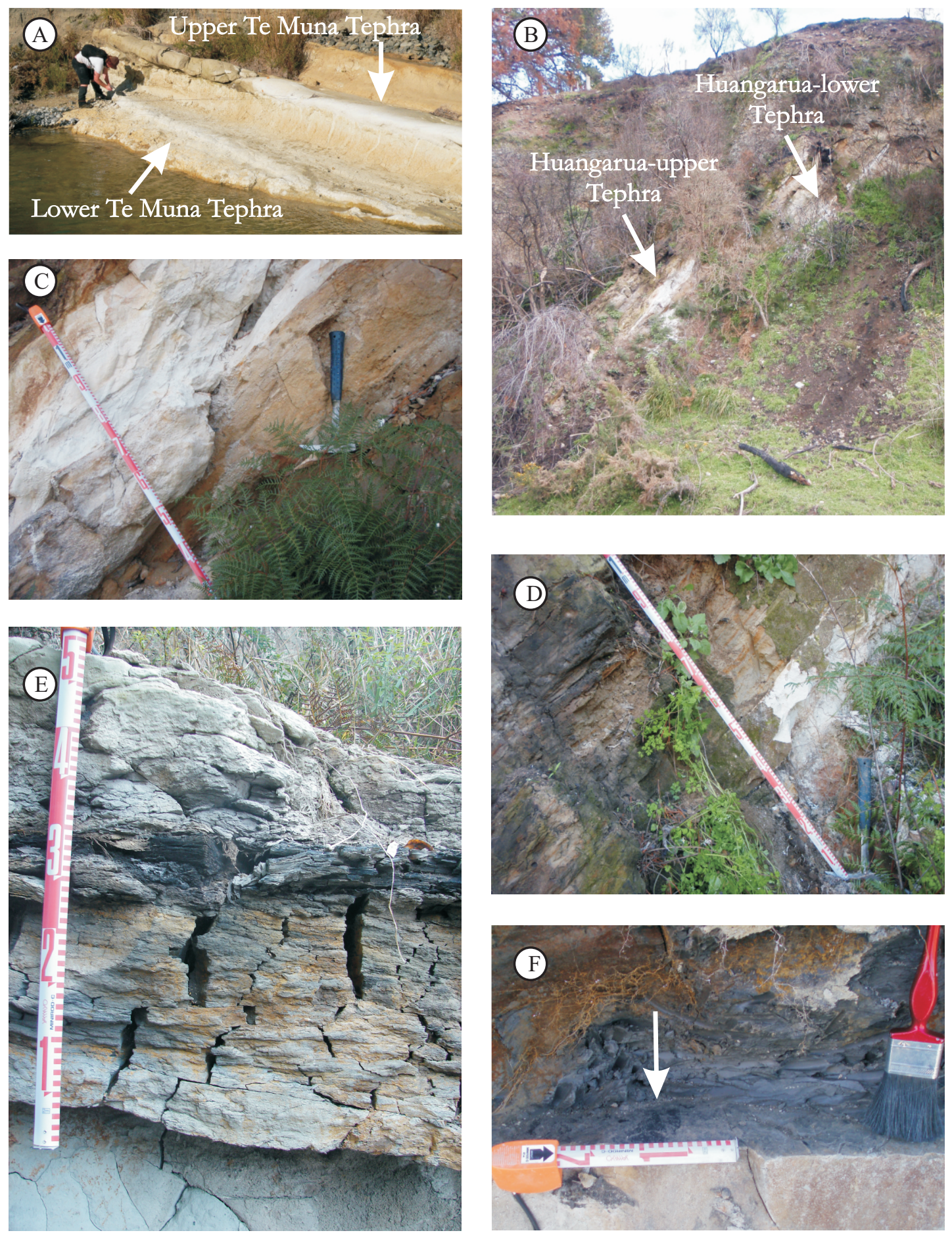

Figure 3.13 A) Upper and Lower Te Muna Tephra surrounded by loess and palaeosols.

These tephra correlate to the Kaukatea and Potaka Tephra respectively. B) Spatial relationship between the Huangarua-upper and Huangarua-lower Tephra at the Huangarua West Measured

Section. C) The Huangarua-upper Tephra, note the sharp basal contact (arrowed). D)

Huangarua-lower Tephra, overlain by bedded mudstone. E) Lignite bed above lowermost Ms unit at Big Bend. Basal $20 \mathrm{~cm}$ of lignite is solely comprised of leaf material, while the upper $8 \mathrm{~cm}$ also contains branches. F) Planar surface of the $O$ bed at the Ruawaka Measured Section showing leaf inprints (arrowed) and muddy character of the facies at this horizon. 

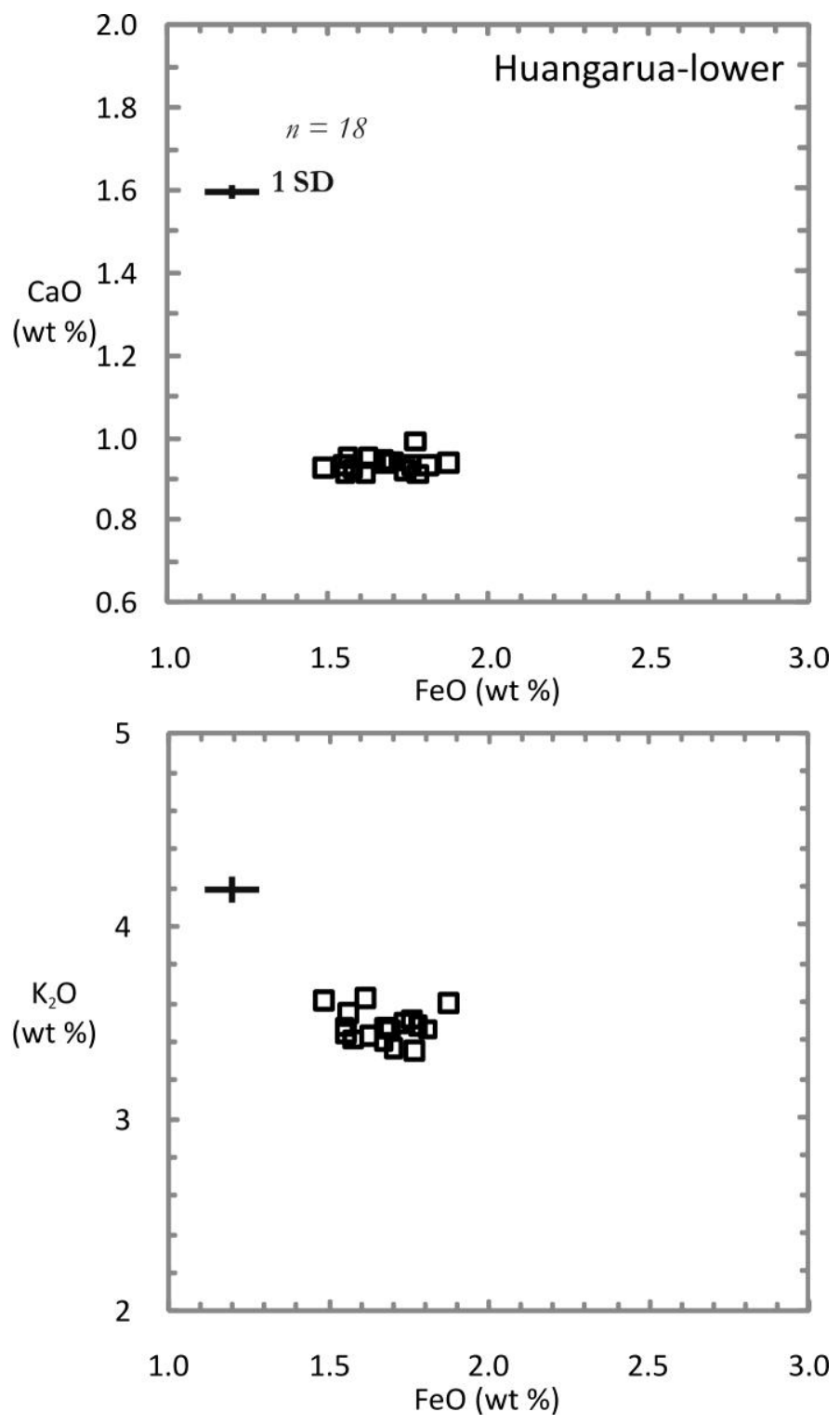

Figure 3.14. Plots of $\mathrm{CaO}$ versus $\mathrm{FeO}$ (top) and $\mathrm{K}_{2} \mathrm{O}$ versus $\mathrm{FeO}$ (base) for the Huangarua-lower Tephra. See Table 3.4 and Appendix Four for details. $n$ is the number of analysis run, bars are one standard deviation.

The Huangarua-lower Tephra appears to correlate closest with a sample AT-405 in ODP Core 1123 (Figure 3.15). Although it occurs within a disturbed section of the core, AT-405 has been assigned a provisional age of 1.625 Ma based upon its stratigraphic position and close proximity to reliably dated tephra (Allan et al., 2008). The Maranoa Tephra (AT-359) from the Wanganui Basin is also included for comparison, but while chemically more similar to the Huangarua-lower Tephra than other Wanganui Basin tephra, the Maranoa Tephra does not appear to be correlative. 

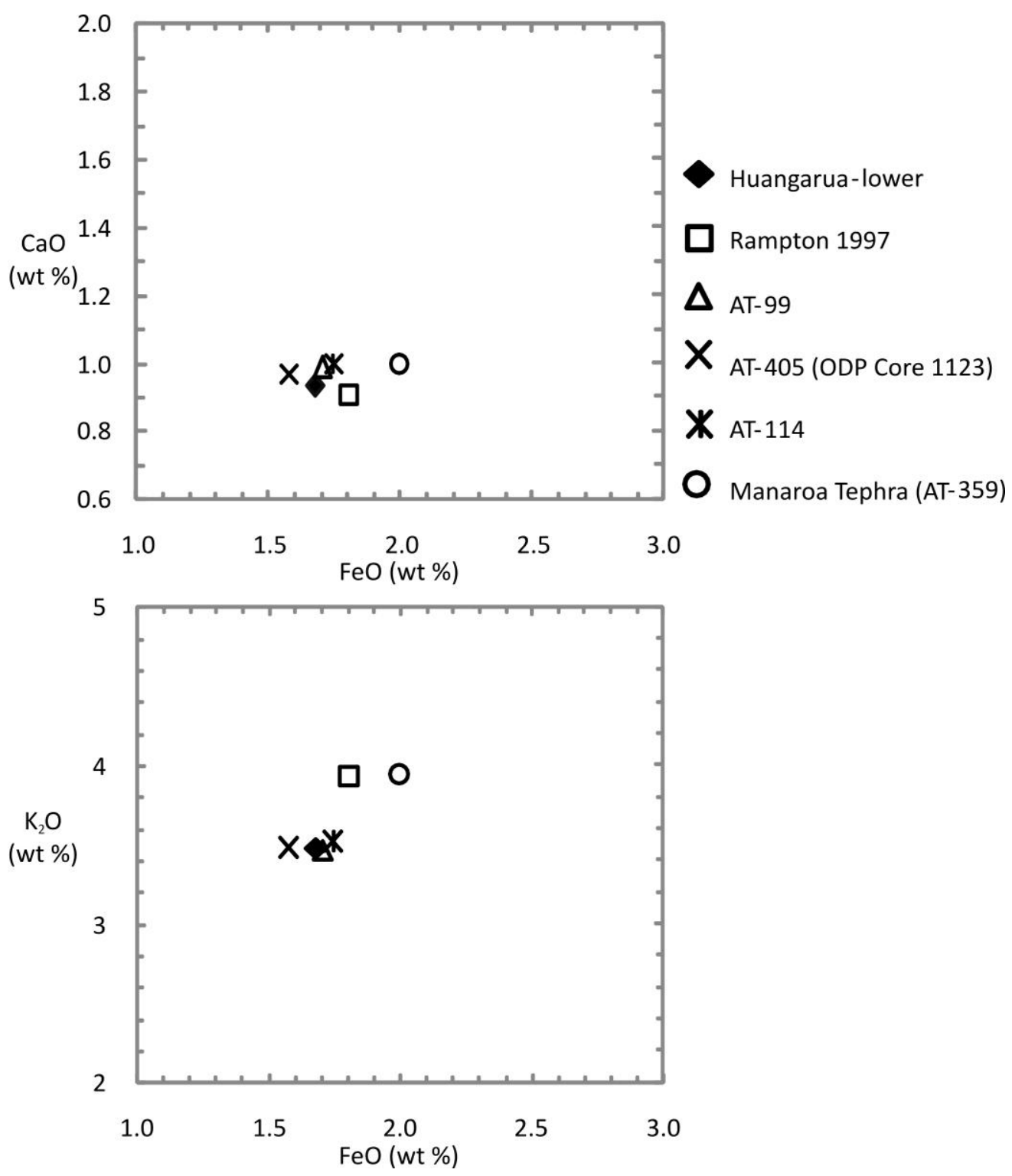

Figure 3.15 Plots of $\mathrm{CaO}$ versus $\mathrm{FeO}$ (top) and $\mathrm{K}_{2} \mathrm{O}$ versus $\mathrm{FeO}$ (base) for the Huangarua-lower Tephra, local and ODP Core correlatives, and the Maranoa Tephra. See Table 3.4 and Appendix Four for details. $\boldsymbol{n}$ is the number of analysis run, bars are one standard deviation.

Huangarua-upper (Rampton, 1997)

The Huangarua-upper Tephra occurs in the lowermost lacustrine unit of the Te Muna Formation, 1.5 metres above the Huangarua-lower Tephra at the Huangarua West Measured Section (Figure 3.13B; Appendix Two). The tephra is a $30 \mathrm{~cm}$ white, normally graded, medium to fine pumiceous ash deposit with a conformable planar lower contact. A large spread in the major element plot and high standard deviation indicate this sample is from multiple sources (Table 3.5; Figure 3.16). 


\begin{tabular}{lrrrrrrrrrrr}
\multicolumn{1}{c}{ Sample/Study } & $\mathrm{SiO}_{2}$ & $\mathrm{Al}_{2} \mathrm{O}_{3}$ & $\mathrm{TiO} 2$ & $\mathrm{FeO}$ & $\mathrm{MgO}$ & $\mathrm{CaO}$ & $\mathrm{Na}_{2} \mathrm{O}$ & $\mathrm{K}_{2} \mathrm{O}$ & $\mathrm{MnO}$ & water & $n$ \\
\hline Huangarua-upper & 75.53 & 13.53 & 0.10 & 1.61 & 0.08 & 0.95 & 4.64 & 3.56 & 0.01 & 4.56 & 33 \\
This study & 0.81 & 0.33 & 0.02 & 0.25 & 0.02 & 0.14 & 0.41 & 0.16 & 0.02 & 1.06 & \\
\hline Huangarua-upper & 76.19 & 13.13 & 0.15 & 1.82 & 0.12 & 1.00 & 3.77 & 3.82 & - & 6.70 & 20 \\
(Rampton 1997) & 0.71 & 0.40 & 0.05 & 0.28 & 0.07 & 0.18 & 0.18 & 0.24 & & 0.74 & \\
AT-98 & 76.03 & 12.82 & 0.15 & 1.89 & 0.07 & 1.07 & 4.25 & 3.57 & - & 5.13 & 13 \\
(Nicol et al., 2002) & 0.90 & 0.28 & 0.08 & 0.36 & 0.02 & 0.19 & 0.45 & 0.23 & & 0.47
\end{tabular}

Table 3.5. Glass composition of the Huangarua-upper Tephra and correlatives from previous studies in the area. All elements calculated on a water-free basis, with water by difference from $100 \%$. All Fe expressed as FeO. Mean and one standard deviation (in italics) based on $n$ analysis. Further details provided in Appendix Four.
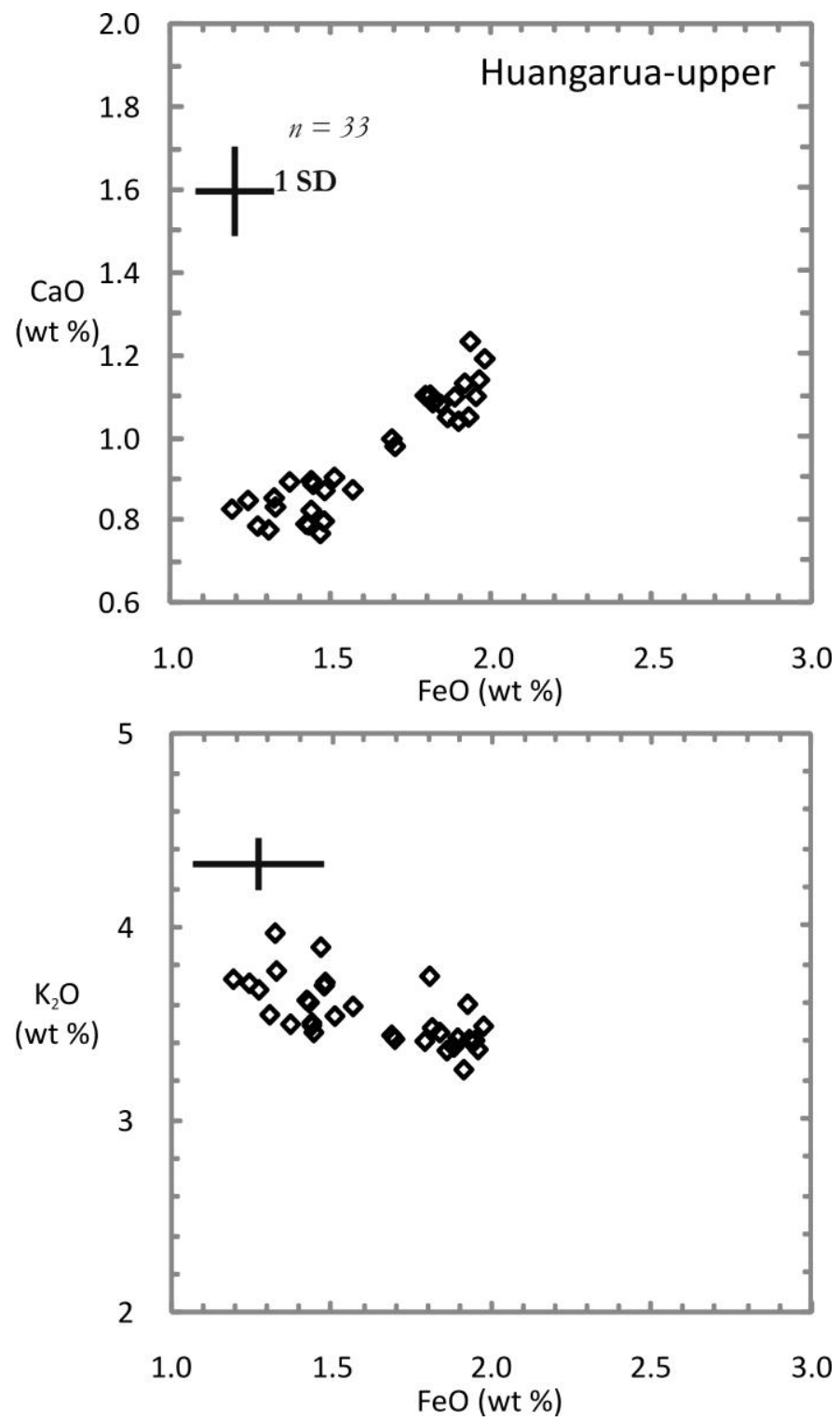

Figure 3.16 Plots of $\mathrm{CaO}$ versus $\mathrm{FeO}$ (top) and $\mathrm{K}_{2} \mathrm{O}$ versus $\mathrm{FeO}$ (base) for the Huangarua-upper Tephra. See Table 3.5 and Appendix Four for details. $n$ is the number of analysis run, bars are one standard deviation. 
Lower Te Muna Tephra (Collen \& Vella, 1984), Potaka Tephra (Shane et al., 1995)

Upper Te Muna Tephra (Collen \& Vella, 1984), Kaukatea Tephra (Shane et al., 1995)

These tephra occur in a sequence also containing palaeosols and loess (Figure 3.13A). The Lower Te Muna Tephra is white, $25 \mathrm{~cm}$ thick, massive, and contains gammate structures. The Lower Te Muna Tephra has previously been correlated with the Potaka Tephra (e.g. Shane et al., 1995; Nicol et al., 2002). The Lower Te Muna Tephra collected for this study has been analysed and the results published by Allan et al., (2008) as an onshore correlative for Potaka Tephra identified in ODP Core 1123. Their results are reproduced here (Table 3.6).

The Potaka Tephra is correlated between a number of onshore and offshore sites, including both the Wanganui and Hawke's Bay Basins (Table 3.6; Figure 3.17). The Potaka Tephra has a number of indistinguishable, well constrained ages, including an ITPDT age of $1.00 \pm 0.03 \mathrm{Ma}$ (Alloway et al., 2004b), and astronomically tuned ages of $0.9977 \mathrm{Ma}$ (from AT-338 ODP Core 1123) and 0.99 Ma from the Wanganui Basin (Naish et al., 1998).

The Upper Te Muna Tephra is white, $30 \mathrm{~cm}$ thick and massive, and is 0.6 metres stratigraphically above the Lower Te Muna Tephra on the true left bank of the Huangarua River. The Upper Te Muna Tephra has previously been correlated with the Kaukatea tephra (e.g. Shane et al., 1995; Nicol et al., 2002).

Glass chemistry here shows the correlation between the Upper Te Muna has a number of Kaukatea tephra correlatives (Table 3.7; Figure 3.19), providing a well constrained age. Based on glass chemistry, tephra in the ODP Cores correlated to the Kaukatea tephra include AT-280 (Site 1122) and AT-289 (Site 1125) (Pillans et al., 2005). The Kaukatea tephra has an ITPFT date of $0.86 \pm 0.08 \mathrm{Ma}$ in the Wanganui Basin, and an astronomically tuned age of $0.90 \mathrm{Ma}$ (Pillans et al., 2005). 


\begin{tabular}{|c|c|c|c|c|c|c|c|c|c|c|c|}
\hline Sample/Study & $\mathrm{SiO}_{2}$ & $\mathrm{Al}_{2} \mathrm{O}_{3}$ & TiO2 & $\mathrm{FeO}$ & $\mathrm{MgO}$ & $\mathrm{CaO}$ & $\mathrm{Na}_{2} \mathrm{O}$ & $\mathrm{K}_{2} \mathrm{O}$ & $\mathrm{MnO}$ & water & $n$ \\
\hline Lower Te Muna Tephra & 77.50 & 12.60 & 0.13 & 1.18 & 0.10 & 0.91 & 3.44 & 3.80 & 0.09 & 4.40 & 15 \\
\hline Allan 2008 & 0.24 & 0.14 & 0.04 & 0.15 & 0.02 & 0.13 & 0.12 & 0.27 & 0.05 & 0.70 & \\
\hline LTM & 77.24 & 12.51 & 0.13 & 1.11 & 0.11 & 0.93 & 4.07 & 3.67 & - & 5.52 & 9 \\
\hline Shane \& Froggatt 1991 & 0.35 & 0.12 & 0.03 & 0.08 & 0.02 & 0.09 & 0.12 & 0.22 & & 0.47 & \\
\hline Lower Te Muna & 77.24 & 12.51 & 0.14 & 1.11 & 0.11 & 0.93 & 4.07 & 3.67 & - & 5.52 & 9 \\
\hline Shane et al., 1995 & 0.3 & 0.07 & 0.03 & 0.08 & 0.02 & 0.09 & 0.12 & 0.22 & & 0.47 & \\
\hline \multicolumn{12}{|l|}{ Correlatives } \\
\hline BP-441 & 78.12 & 12.05 & 0.12 & 1.09 & 0.11 & 0.89 & 3.53 & 3.87 & - & 4.71 & 12 \\
\hline (Pillans et al., 2005) & 0.29 & 0.17 & 0.03 & 0.12 & 0.02 & 0.08 & 0.19 & 0.24 & & 1.15 & \\
\hline BP-545 & 77.58 & 12.10 & 0.18 & 1.07 & 0.12 & 0.86 & 3.79 & 4.07 & - & 5.57 & 12 \\
\hline (Pillans et al., 2005) & 0.44 & 0.37 & 0.04 & 0.15 & 0.04 & 0.12 & 0.18 & 0.20 & & 1.23 & \\
\hline BP-478/11B & 77.90 & 12.15 & 0.10 & 1.08 & 0.10 & 0.88 & 3.57 & 3.95 & - & 5.90 & 7 \\
\hline (Pillans et al., 2005) & 0.28 & 0.14 & 0.03 & 0.13 & 0.04 & 0.09 & 0.09 & 0.27 & & 1.36 & \\
\hline BP-484 & 77.84 & 12.15 & 0.10 & 1.09 & 0.11 & 0.93 & 3.69 & 3.97 & - & 3.28 & 18 \\
\hline (Pillans et al., 2005) & 0.49 & 0.16 & 0.03 & 0.12 & 0.03 & 0.10 & 0.11 & 0.15 & & 1.05 & \\
\hline BP478/19 & 78.00 & 12.20 & 0.12 & 1.12 & 0.11 & 0.93 & 3.40 & 3.90 & - & 4.50 & 13 \\
\hline (Pillans et al., 2005) & 0.43 & 0.17 & 0.04 & 0.11 & 0.04 & 0.12 & 0.22 & 0.19 & & 1.17 & \\
\hline BP-483 - = - & 77.88 & 12.13 & 0.12 & 1.05 & 0.11 & 0.85 & 3.59 & 4.05 & - & 2.96 & 11 \\
\hline (Pillans et al., 2005) & 0.16 & 0.12 & 0.04 & 0.11 & 0.03 & 0.10 & 0.13 & 0.25 & & 1.28 & \\
\hline BP560 & 77.50 & 12.23 & 0.15 & 1.19 & 0.11 & 0.85 & 3.69 & 3.98 & - & 4.17 & 11 \\
\hline (Pillans et al., 2005) & 0.30 & 0.16 & 0.04 & 0.16 & 0.02 & 0.13 & 0.10 & 0.12 & & 0.77 & \\
\hline BP-506b & 77.59 & 12.33 & 0.14 & 1.03 & 0.13 & 0.87 & 3.59 & 4.10 & - & 3.85 & 6 \\
\hline (Pillans et al., 2005) & 0.18 & 0.10 & 0.04 & 0.09 & 0.04 & 0.09 & 0.11 & 0.19 & & 0.79 & \\
\hline BP-485 & 77.80 & 12.12 & 0.10 & 1.08 & 0.09 & 0.88 & 3.59 & 4.12 & - & 3.56 & 13 \\
\hline (Pillans et al., 2005) & 0.28 & 0.15 & 0.04 & 0.14 & 0.03 & 0.09 & 0.18 & 0.24 & & 1.18 & \\
\hline BP-305 & 78.07 & 11.87 & 0.14 & 1.19 & 0.10 & 0.99 & 3.72 & 3.68 & - & 6.01 & 11 \\
\hline (Pillans et al., 2005) & 0.22 & 0.16 & 0.02 & 0.08 & 0.05 & 0.06 & 0.19 & 0.15 & & 0.52 & \\
\hline AT-229 & 77.05 & 12.67 & 0.21 & 1.25 & 0.14 & 0.86 & 3.61 & 3.93 & - & 1.42 & 10 \\
\hline (Pillans et al., 2005) & 0.30 & 0.15 & 0.06 & 0.20 & 0.03 & 0.10 & 0.09 & 0.20 & & 1.18 & \\
\hline AT-230 & 77.05 & 12.63 & 0.18 & 1.26 & 0.10 & 0.86 & 3.53 & 4.13 & - & 1.52 & 12 \\
\hline (Pillans et al., 2005) & 0.32 & 0.09 & 0.07 & 0.23 & 0.04 & 0.14 & 0.11 & 0.18 & & 0.66 & \\
\hline DMBP-18 & 76.78 & 13.09 & 0.13 & 1.15 & 0.11 & 0.84 & 3.41 & 4.27 & - & 7.05 & 16 \\
\hline (Pillans et al., 2005) & 0.47 & 0.29 & 0.04 & 0.14 & 0.04 & 0.13 & 0.19 & 0.29 & & 1.62 & \\
\hline DMBP-3 & 76.75 & 13.10 & 0.14 & 1.09 & 0.10 & 0.84 & 3.50 & 4.24 & - & 6.86 & 12 \\
\hline (Pillans et al., 2005) & 0.44 & 0.12 & 0.03 & 0.13 & 0.04 & 0.11 & 0.16 & 0.30 & & 1.36 & \\
\hline AT-281 & 77.86 & 12.39 & 0.11 & 1.13 & 0.10 & 0.87 & 3.55 & 3.75 & - & 4.21 & 15 \\
\hline (Alloway et al., 2005) & 0.17 & 0.11 & 0.05 & 0.13 & 0.02 & 0.12 & 0.10 & 0.23 & & 0.69 & \\
\hline AT-338 & 77.43 & 12.30 & 0.11 & 1.16 & 0.09 & 0.90 & 4.09 & 3.70 & - & 4.69 & 14 \\
\hline (Alloway et al., 2005) & 0.66 & 0.28 & 0.05 & 0.30 & 0.02 & 0.13 & 0.26 & 0.36 & & 0.77 & \\
\hline AT-322 & 77.67 & 12.55 & 0.09 & 1.17 & 0.07 & 0.78 & 3.86 & 3.66 & - & 7.30 & 15 \\
\hline (Alloway et al., 2005) & 0.16 & 0.07 & 0.07 & 0.06 & 0.02 & 0.04 & 0.10 & 0.10 & & 0.46 & \\
\hline
\end{tabular}

Table 3.6. Glass composition of the Lower Te Muna Tephra and Potaka Tephra correlatives from the Wanganui Basin and OPD Cores. All elements calculated on a water-free basis, with water by difference from $100 \%$. All Fe expressed as FeO. Mean and one standard deviation (in italics) based on $\boldsymbol{n}$ analysis. Further details provided in Appendix Four, locations of correlatives provided in Appendix Seven. 


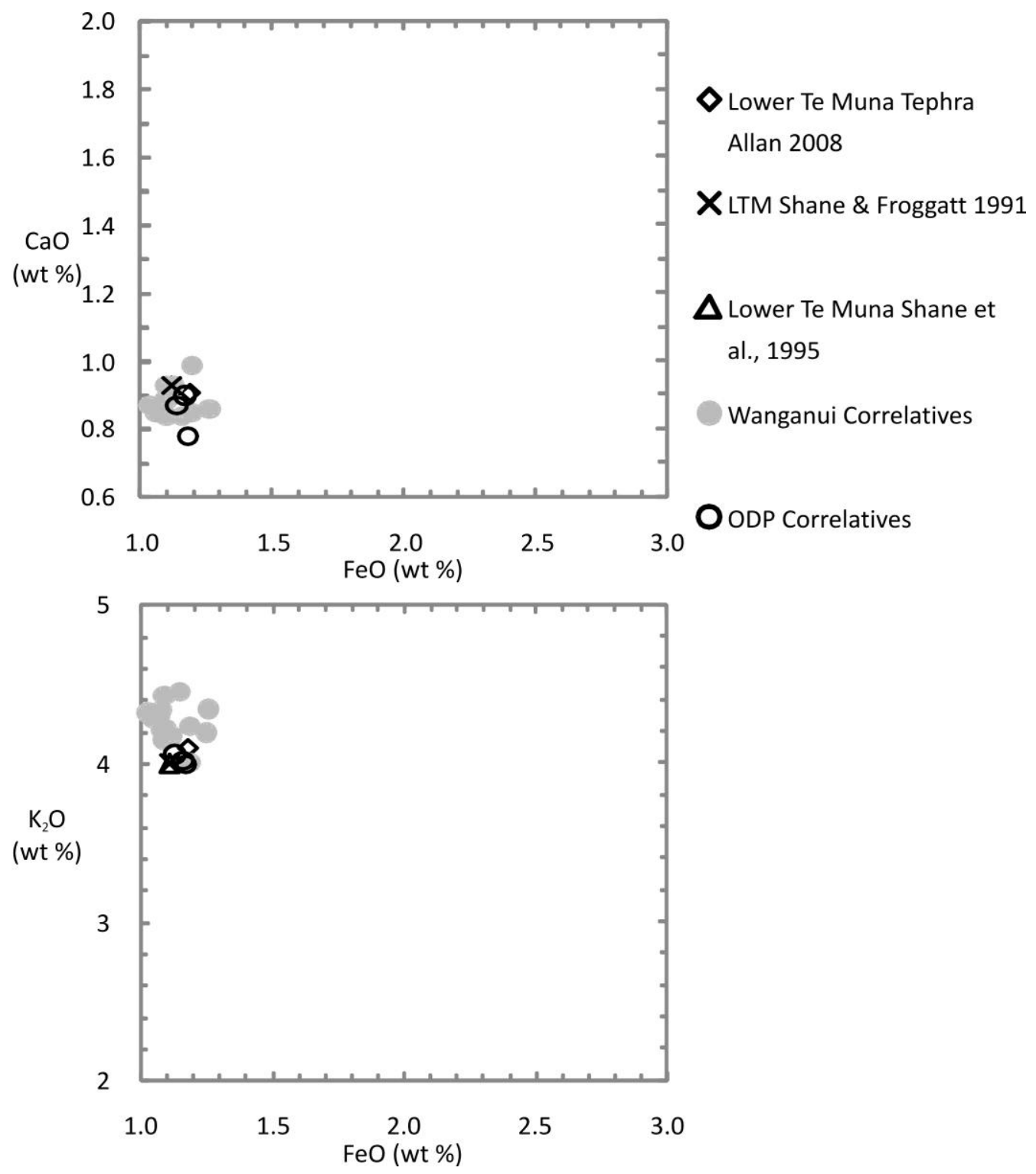

Figure 3.17 Plots of $\mathrm{CaO}$ versus $\mathrm{FeO}$ (top) and $\mathrm{K}_{2} \mathrm{O}$ versus $\mathrm{FeO}$ (base) for the Lower Te Muna Tephra, 14 Wanganui Basin and three ODP Core correlatives. See Table 3.5 and Appendix Four for details. $\boldsymbol{n}$ is the number of analysis run, bars are one standard deviation. 


\begin{tabular}{|c|c|c|c|c|c|c|c|c|c|c|c|}
\hline Sample/Study & $\mathrm{SiO}_{2}$ & $\mathrm{Al}_{2} \mathrm{O}_{3}$ & $\mathrm{TiO} 2$ & $\mathrm{FeO}$ & $\mathrm{MgO}$ & $\mathrm{CaO}$ & $\mathrm{Na}_{2} \mathrm{O}$ & $\mathrm{K}_{2} \mathrm{O}$ & $\mathrm{MnO}$ & water & $n$ \\
\hline Upper Te Muna Tephra & 75.45 & 13.57 & 0.15 & 1.50 & 0.14 & 1.01 & 4.73 & 3.45 & 0.00 & 3.51 & 17 \\
\hline This Study & 0.12 & 0.11 & 0.02 & 0.07 & 0.02 & 0.02 & 0.13 & 0.08 & 0.00 & 0.42 & \\
\hline UTM & 76.5 & 13.31 & 0.17 & 1.56 & 0.15 & 1.09 & 4.48 & 3.54 & - & 6.57 & 12 \\
\hline Shane et al., 1996 & 0.4 & 0.28 & 0.04 & 0.08 & 0.01 & 0.05 & 0.15 & 0.14 & & 1.01 & \\
\hline Upper Te Muna & 75.5 & 13.31 & 0.17 & 1.56 & 0.15 & 1.09 & 4.48 & 3.54 & - & 6.57 & 12 \\
\hline Shane et al., 1995 & 0.4 & 0.28 & 0.04 & 0.08 & 0.01 & 0.05 & 0.15 & 0.14 & & 1.01 & \\
\hline \multicolumn{12}{|l|}{ Correlatives } \\
\hline BP-486 & 76.88 & 12.7 & 0.13 & 1.48 & 0.11 & 0.98 & 4.11 & 3.45 & - & 5.23 & 12 \\
\hline (Pillans et al., 2005) & 0.32 & 0.19 & 0.04 & 0.12 & 0.03 & 0.07 & 0.12 & 0.14 & & 0.58 & \\
\hline BP232 & 76.85 & 12.75 & 0.15 & 1.53 & 0.12 & 0.99 & 4.04 & 3.44 & - & 5.66 & 16 \\
\hline (Pillans et al., 2005) & 0.27 & 0.19 & 0.04 & 0.07 & 0.02 & 0.06 & 0.26 & 0.18 & & 0.75 & \\
\hline BP468 & 76.6 & 12.72 & 0.13 & 1.54 & 0.12 & 0.98 & 4.28 & 3.44 & - & 5.35 & 22 \\
\hline (Pillans et al., 2005) & 0.33 & 0.08 & 0.04 & 0.12 & 0.02 & 0.05 & 0.19 & 0.25 & & 0.77 & \\
\hline BP-478/16 & 76.27 & 12.77 & 0.22 & 1.63 & 0.16 & 1.07 & 4.27 & 3.4 & - & 6.25 & 11 \\
\hline (Pillans et al., 2005) & 0.37 & 0.16 & 0.03 & 0.15 & 0.03 & 0.06 & 0.16 & 0.25 & & 1.21 & \\
\hline BP-506a & 75.99 & 12.96 & 0.2 & 1.55 & 0.14 & 1.05 & 4.39 & 3.54 & - & 5.56 & 7 \\
\hline (Pillans et al., 2005) & 0.27 & 0.17 & 0.04 & 0.11 & 0.03 & 0.09 & 0.16 & 0.22 & & 0.85 & \\
\hline AT-423 & 76.68 & 13.04 & 0.14 & 1.58 & 0.13 & 0.97 & 4.46 & 3.32 & - & 6.83 & 16 \\
\hline (Alloway et al., 2005) & 0.19 & 0.1 & 0.04 & 0.05 & 0.03 & 0.04 & 0.14 & 0.12 & & 0.91 & \\
\hline AT-289 & 76.72 & 13.03 & 0.13 & 1.62 & 0.12 & 1.02 & 3.83 & 3.28 & - & 5.23 & 12 \\
\hline (Alloway et al., 2005) & 0.29 & 0.08 & 0.08 & 0.08 & 0.02 & 0.03 & 0.21 & 0.11 & & 0.58 & \\
\hline AT-280 & 76.61 & 13.07 & 0.16 & 1.58 & 0.12 & 0.99 & 3.87 & 3.37 & - & 4.34 & 15 \\
\hline (Alloway et al., 2005) & 0.3 & 0.12 & 0.07 & 0.06 & 0.02 & 0.08 & 0.45 & 0.23 & & 0.67 & \\
\hline
\end{tabular}

Table 3.6. Glass composition of the Upper Te Muna Tephra and Kaukatea Tephra correlatives from the Wanganui Basin and OPD Cores. All elements calculated on a water-free basis, with water by difference from $\mathbf{1 0 0 \%}$. All Fe expressed as FeO. Mean and one standard deviation (in italics) based on $\boldsymbol{n}$ analysis. Further details provided in Appendix Four, locations of correlatives provided in Appendix Seven. 

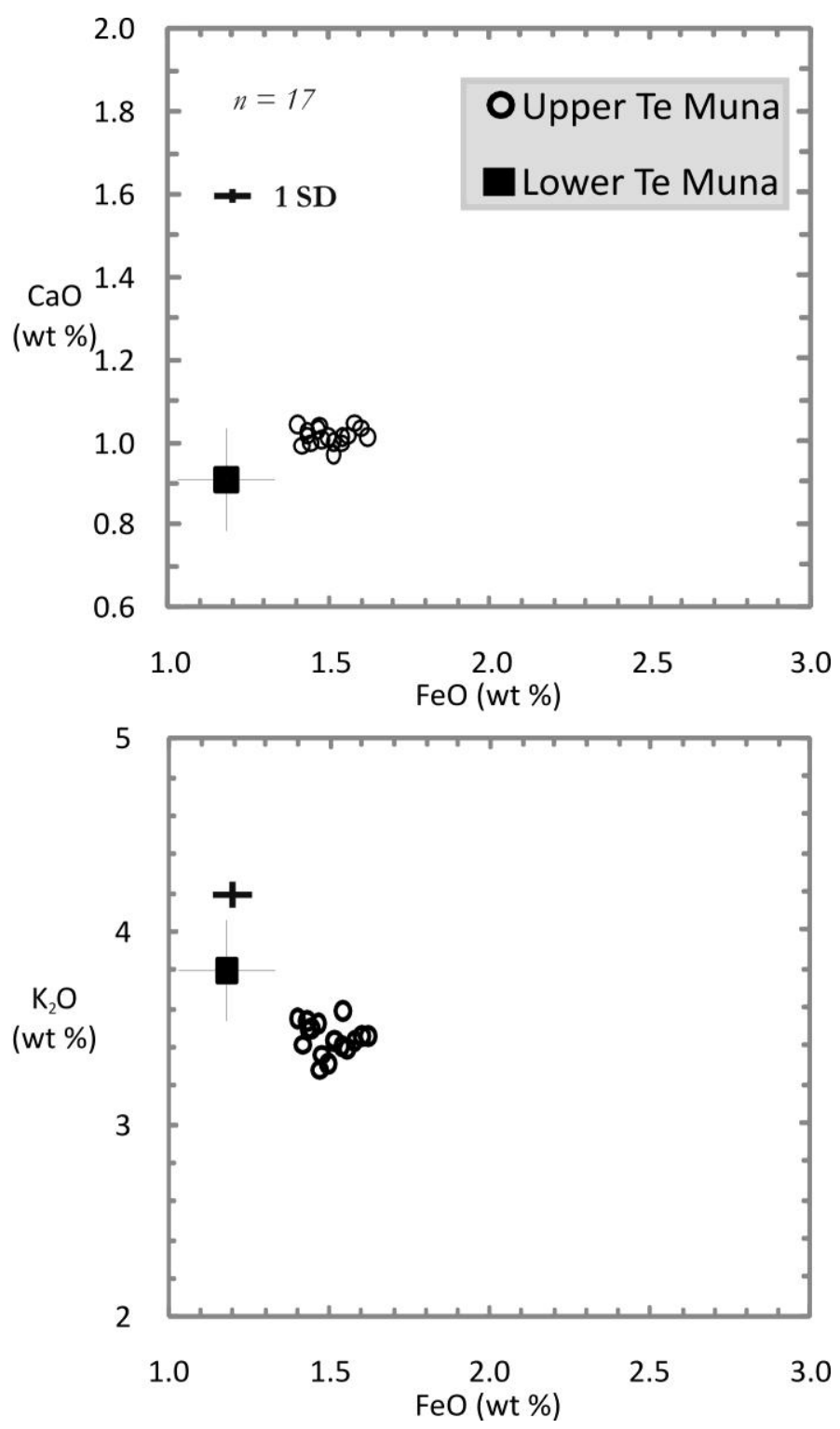

Figure 3.18 Plots of $\mathrm{CaO}$ versus $\mathrm{FeO}$ (top) and $\mathrm{K}_{2} \mathrm{O}$ versus $\mathrm{FeO}$ (base) for the Upper Te Muna Tephra in this study. See Table 3.6 and Appendix Four for details. $n$ is the number of analysis run for the Upper Te Muna Tephra, thick bars are one standard deviation from the mean for the Upper Te Muna Tephra, and hairline bars are one standard deviation from the mean for the Lower Te Muna Tephra of Allan (2008). 

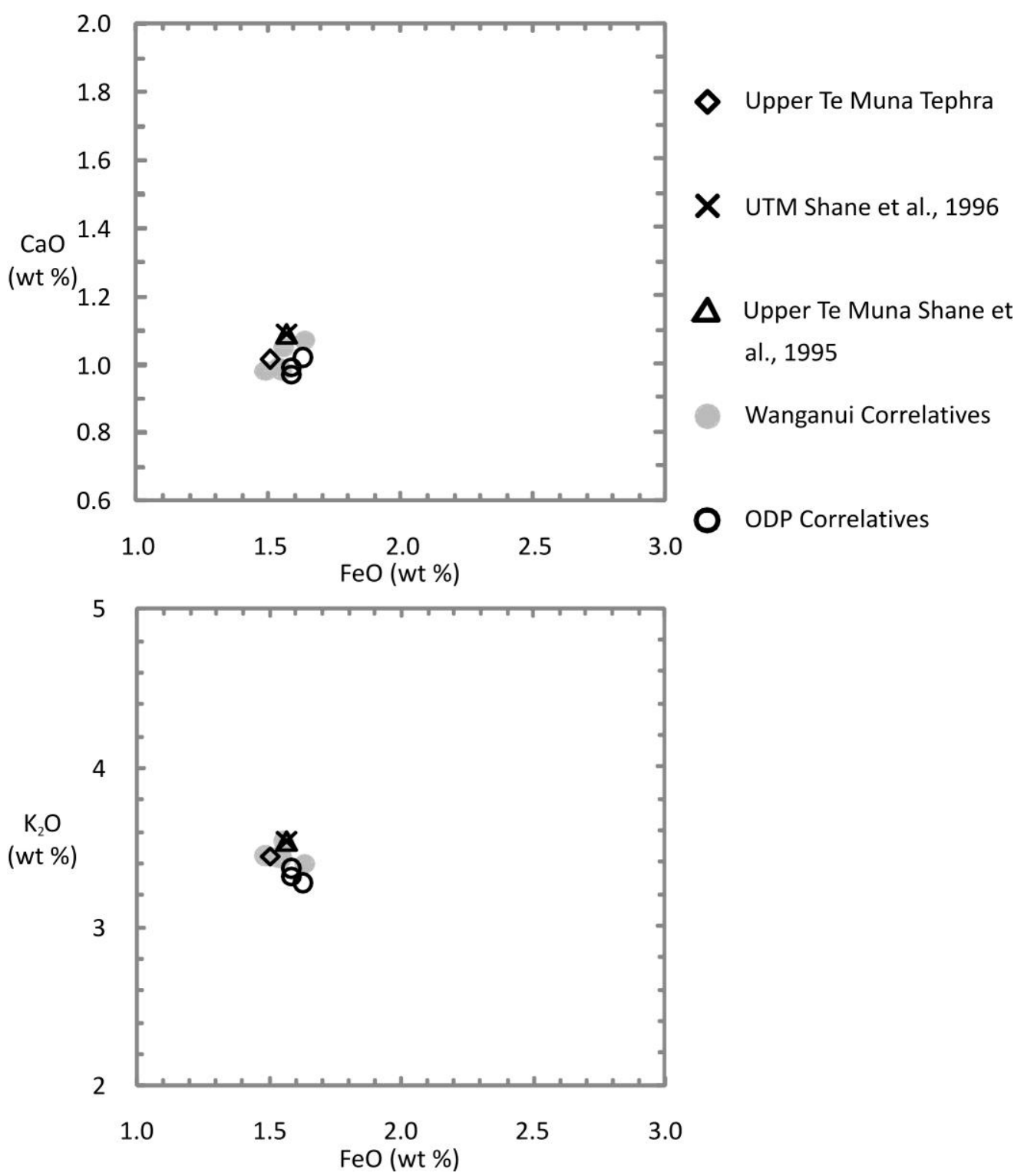

Figure 3.19 Plots of $\mathrm{CaO}$ versus $\mathrm{FeO}$ (top) and $\mathrm{K}_{2} \mathrm{O}$ versus $\mathrm{FeO}$ (base) for the Upper Te Muna Tephra, five Wanganui Basin and three ODP Core correlatives. See Table 3.5 and Appendix Four for details. $n$ is the number of analysis run, bars are one standard deviation. 


\subsection{Facies O - Organic}

The $\mathbf{O}$ facies is a brown-to-black, brittle-to-firm, massive-to-laminated, often muddy, overwhelmingly carbonaceous deposit. The $\mathbf{O}$ facies is extensively- to nonbioturbated, and variably contains lignite seams, leaf imprints, twigs, reeds, plant cuticles, pollen and in some cases larger branches and logs (Figure 3.13F). The lignite and muddy, massive beds of $\mathbf{O}$ are thin, up to $25 \mathrm{~cm}$ thick, while the logdominated deposits can reach $2 \mathrm{~m}$ in thickness (Figure 3.13E).

\section{Depositional Environment}

The variable $\mathbf{O}$ facies is interpreted as being deposited within a range of non-marine environments. Settings include swamps and flood deposits within the lacustrine settings, and catastrophic event accumulations overlying the volcaniclastic (V) facies (Bussell \& Pillans, 1992).

(opposite page)

Table 3.8 Facies summary 


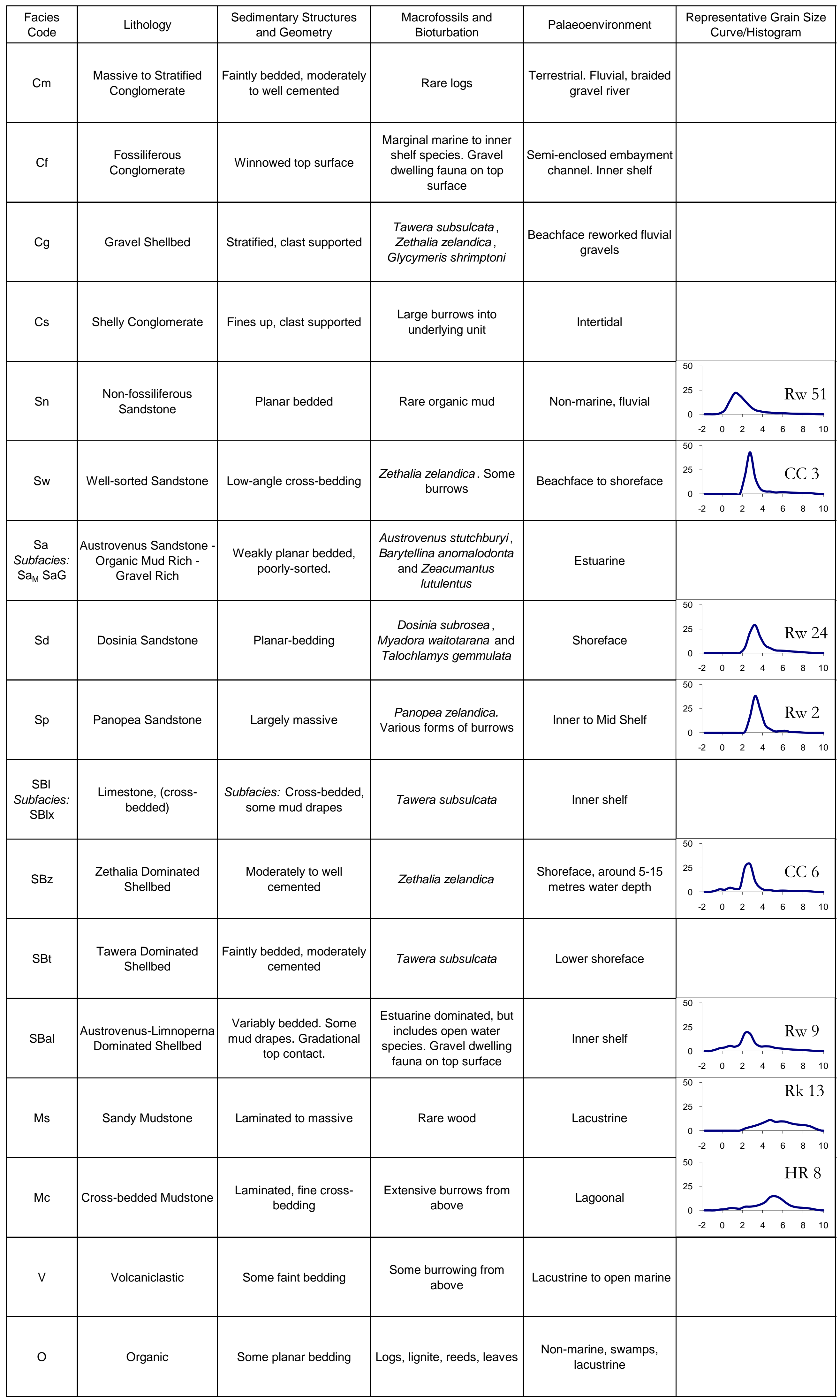




\section{Chapter Four \\ Stratigraphic Architecture and Cyclicity}

\subsection{Introduction}

This chapter aims to identify patterns in the deposition of the Te Muna and Hautotara formations, and will attempt to place these within a sequence stratigraphic framework. This will be done by analysing the vertical stacking of the facies described in Chapter Three and documented in Appendix Two. Importantly, especially when considering the marginal marine setting of the Hautotara Formation, the relationship between the autocyclic (intra-basinal) and allocyclic (extra-basinal) processes will be identified, and thereby ensuring local events are not ascribed to global effects such as the Milankovitch orbital variations. Therefore, this chapter will firstly review the East Coast Basin's sequence stratigraphic model, in particular the relevant surfaces and systems tracts. Secondly, the dominant stacking patterns (motifs) of the study area will be presented, before a discussion of the variations across the study area, and the implications for the palaeogeography of the area.

As the Wairarapa Valley is within a similar setting as the Hawke's Bay (Figures 1.11.2), the concepts and stratigraphy of the extensive sequence stratigraphic work in the backarc Wanganui Basin (e.g. Naish, 2005) is not as applicable as that of the recent Hawke's Bay work. Therefore this work borrows from the results of sequence stratigraphic work in the Hawke's Bay region, particularly that of Haywick (2000) and Bland (2006), and re-examines the controls on the Hautotara Formation. 


\subsection{Background}

A number of previous studies have highlighted the cyclicity of the of the late Neogene sediments of the Wairarapa. Vella (1963a) was the first to recognise the cycles as a major feature of the succession, and identified four cyclothems through an area immediately north of this study area, of which the Eringa and Huangarua Cyclothems encompass rocks of the Pukenui Limestone and Hautotara Formation.

Collen \& Vella (1984) constrained the Hautotara Formation to between one and one and a half cycles. This was based on the Pukenui Limestone and Hautotara Formation containing a total of seven cycles, and the Pukenui Limestone having evidence for slightly over five of these (Collen \& Vella 1984).

Gammon (1995) inferred the Hautotara Formation to represent at least five glacioeustatic cycles. This was based on the composite standard section that combined data from a number of his individual sections, the works of Collen \& Vella (1984), and Rodley (1961). However, there is difficulty following the intended tie points of the composite section, and the composite section does still not include the full stratigraphy of the Hautotara Formation (Gammon 1995).

Rampton (1997) in a study that incorporated the northeast of this study area, identified up to five $40 \mathrm{kyr}$ cycles in the Hautotara Formation. Two of his stratigraphic sections are reproduced later in this chapter to further constrain the basin response to the effects of sedimentation, tectonism and sea-level change.

Here, the sequence stratigraphic cycles observed in the Hautotara and Te Muna formations are attributed to glacio-eustatic sea-level changes. Based on the age of deposition of the Hautotara Formation the major sequences are believed to be as a result of the $6^{\text {th }}$ order (41 kyr) driven climatic oscillations, while the upper Te Muna Formation incorporates the 'Mid-Pleistocene Transition', where the control of glacio-eustatic cycles changes from the $6^{\text {th }}$ to the $5^{\text {th }}$ order $(100 \mathrm{kyr})$ driver (e.g. Naish, 2005). 
Within this chapter, and for the remainder of this thesis, it is assumed the depositional environments of the facies described in Chapter Three are accepted. Therefore, to allow a flowing description of the various beds, tracts and environments to be discussed, the environment of deposition will be discussed in place of the assigned facies name. For example, the 'muddy to gravelly sandstone (Sa) interpreted as being deposited in an estuarine environment' may be described as an 'estuarine sandstone'. For detailed descriptions of the facies at particular measured sections, independent of interpretation, the reader is referred to Appendix Two.

The interpreted settings for the systems tracts and surfaces described in this chapter are presented in Figures 4.1 and 4.2, while a summary fence diagram is located after the section descriptions (Figure 4.5).

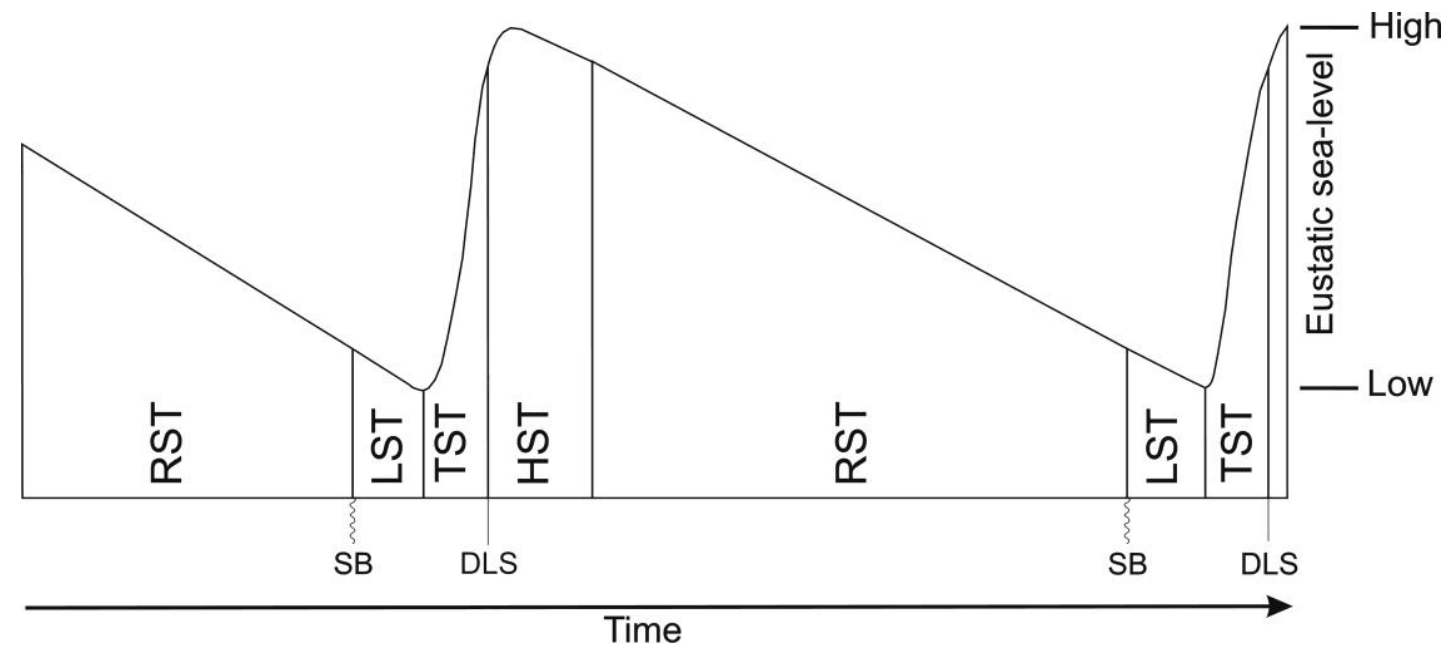

Figure 4.1 Interpreted sea-level changes through time, and their relationship to the systems tract and surfaces. Note the time taken for the Regressive Systems Tract as Polar Ice slowly accumulates (Modified from Bland, 2006). 


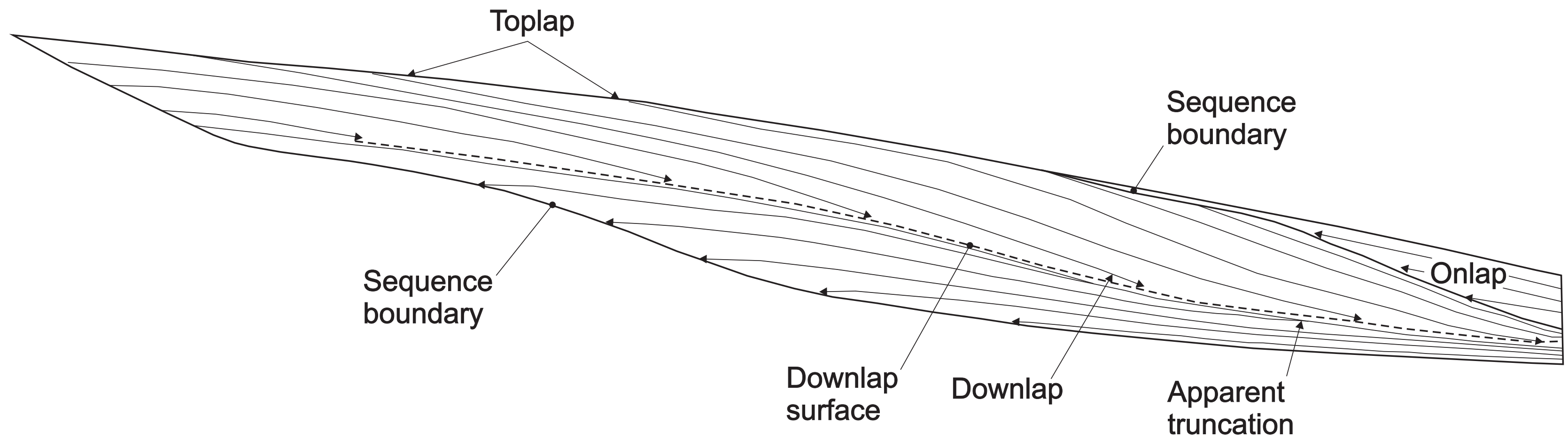

Sequence boundary 


\subsection{Systems Tracts and Surfaces}

\subsubsection{Lowstand system tract (LST):}

The lowstand systems tract refers to sediment accumulation during the lowest relative sea-levels of a cycle (Figure 4.1). In the case of the glacio-eustatic driven cycles of the study area, this systems tract refers to a glacial period. Here, the Hawke's Bay/East Coast Basin's model tends to differ from the Wanganui Basin setting, as the East Coast LST's are dominated by fluvial aggradation as a result of high-bedload river systems that produce low gradient fan-delta systems on the exposed continental shelf (Browne \& Naish, 2003; Bland, 2006).

\subsubsection{Transgressive surface of erosion (TSE):}

A transgressive surface of erosion is formed during the early rise of sea levels, as wave base moves landwards with rising sea level (Caron et al., 2004). The high energy shoreface setting of the TSE causes reworking and erosion of sediments deposited within previous system tracts. The TSE often overlies shoreface sediments, although this depends on the thickness of the sediment package reworked by the TSE. The TSE however, always underlies a deepening succession of sediments.

\subsubsection{Transgressive systems tract (TST):}

The transgressive systems tract contains the sediment accumulated during relative sea-level rise (Figure 4.1). The TST is usually a thin systems tract, and represents only a short period of time in the glacio-eustatic sea-level cycle, as the rise in sealevel is probably a result of rapid polar ice sheet collapse.

Back-stepping of the shoreface wedge causes sediment starvation on the shelf during a TST (Caron, 2004), which in turn allows bioclastic rich facies to accumulate, while an increase in terrestrial vegetation as a result of climatic warming will also cause a decrease in erosion. As a result, the TST may variably contain mechanically 
deposited limestones (Abbott \& Carter, 1994; Naish \& Kamp, 1997), or reworked pebbles and pebbly shellbeds (Abbott, 1998; Bland, 2006).

\subsubsection{Downlap surface (DLS):}

The downlap surface (DLS) is at the top of the TST, and therefore representing the deepest relative sea-level (Figure 4.1). Therefore the DSL also equates to the maximum flooding surface (MFS) - and is at the 'centre' of the cycles. The DLS is often associated with the downlap shellbed (which overlies the DLS), and the backlap shellbed (located underneath the DLS). The DSL is the position in the stratigraphic package where progradation replaces retrogradation, that is, this surface represents the point in the cycle where landward accommodation space has been filled, or eustatic sea-level falls, thereby forcing the sedimentary system to build basinward (Kidwell 1991; Naish \& Kamp, 1997).

\subsubsection{Highstand systems tract (HST):}

The sediments of the highstand systems tract are deposited during the late rise to early fall of relative sea-level (Figure 4.1). As deposition of the Hautotara and Te Muna formations occurs in the Pleistocene epoch, this system tract coincides with the interglacial phase. The HST is the beginning of progradation in a cycle, and overlies the DLS. The HST is comprised of the finest-grained marine sediments. The HST then passes into the RST, and sediment begins to coarsen upwards.

\subsubsection{Regressive surface of erosion (RSE):}

The regressive surface of erosion may be found between the HST and the regressive systems tract (RST). The RSE represents rapid sea-level fall, where shoreface wave action affects progressively further seaward offshore sediments deposited during the previous HST (Hunt \& Tucker 1992; Nummendal \& Swift 1987). The RSE is not recognised in the sediments of this study. 


\subsubsection{Regressive systems tract (RST):}

The regressive systems tract contains all sediments deposited after the RSE (or more practically, the HST) and before the sequence boundary (SB) as defined in this study. The RST is the longest lasting systems tract in the cycle, as sea-level falls slowly as the ice sheets grow in volume. For sediment to be deposited within the RST, the right rate of sediment flux and basin subsidence must be achieved. The RST represents a shallowing of the depositional environments, and often contains massive, well-sorted, and coarser sands than the underlying HST sediments (Bland, 2006). As opposed to the idealised model, the lower surface of the RST is often gradational (Naish \& Kamp, 1997), and therefore its location is relatively arbitrary within the coarsening up sequence of a cycle.

Although dominated by siliciclastic sandstones, the RST may also be associated with a series of diagnostic shellbeds including the toplap shellbed (Kidwell, 1991; Kondo et al., 1998; Naish \& Kamp, 1997), and event concentrated shellbed (Bland, 2006; Hendy et al., 2006).

\subsubsection{Sequence Boundary (SB):}

Sequence boundaries enclose the packages of sediments within sequences, and are therefore critical surfaces to identify in a stratigraphic succession. The definition and hence the location of the sequence boundary within a sequence has varied, largely as a result of workers varying definitions, basin dynamics and stratigraphic resolution (e.g. Abbott et al., 2005; Haywick, 2000; Bland, 2006). Within previous Hawke's Bay/East Coast sequence stratigraphic studies, the sequence boundary has been placed at either the erosional base of non-marine deposits (Haywick, 2000), or the upper surface of the non-marine beds, below the TSE (Bland, 2006). The difference between the two studies is the latter's recognition that non-marine beds are chronologically linked to marine deposits, and therefore are not restricted to the LST's (Bland 2006). 
Although the definition of Bland (2006) is appropriate to his regional study undertaken in the Hawke's Bay, this study is restricted to marginal marine and terrestrial sediments within a narrow strip of the emerging basin, largely distant from basement rock sources (Figure 1.2). Therefore the sequence boundary in this study is placed at the lower boundary of the LST, or the base of non-marine conglomerates (Cm facies) where preserved. This has a number of advantages in recognising the SB within the sediments described in the study area:

a) The Cm facies of the LST is completely reworked into the Cs facies above a TSE in many of the cycles observed; therefore the SB remains on the same plane as intended by Bland (2006).

b) Sedimentation in the Te Muna Formation is dominated by the $\mathbf{C m}$ and $\mathbf{M s}$ facies. This non-marine deposition lacks a detailed stratigraphic signature of the respective systems tracts, but within the study area the base of the $\mathbf{C m}$ is believed to correlate to the base of the LST, whereas the LST - TST plane is not readily identifiable in the facies.

c) No $\mathbf{C m}$ is identified as being deposited into the Hautotara Formation in systems tracts other than the LST, therefore the base of the $\mathbf{C m}$ represents the same cyclic position in all motifs presented (Figure 4.2-4.3). 


\subsection{Stratigraphic Architecture of the Study Area}

The facies analysis of the study area identifies cyclic sedimentary packages within the Hautotara Formation, and these packages can be correlated to six and a half glacio-eustatic sea-level cycles. Although only the lower Te Muna Formation is documented in the measured sections, by supplementing this data with the works of previous studies on the formation, at least seven and a half cycles are identified within the Te Muna Formation. Four sequence motifs are identified within the Hautotara and Te Muna formations, although variations do occur within individual cycles, largely as a result of autocyclic processes. Variations from the 'standard' motifs are as a result of the influence of local palaeogeography and tectonism on deposition, and these will be used to discern the major changes in the palaeogeography of the study area through time.

\subsubsection{Motif One: Eringa Motif}

The lowermost motif identified in the Hautotara Formation is named after the Eringa Cyclothem of Vella (1963a). The Eringa Cyclothem incorporates the entire Pukenui Limestone, and the lower Hautotara Formation. Presciently Vella identified 'microcyclothems' in the Eringa Cyclothem at Makara Stream, and states "presumably only at Makara Stream were rates of down-drop and deposition balanced just right to record the small fluctuations so clearly". The typical stratigraphic architecture of these 'small fluctuations' identified by Vella is the Eringa Motif.

The motif appears to be the dominant cycle of the Pukenui Limestone, and also appears in the lower Hautotara Formation at some locations. The base of the cycle is a cross-bedded shellhash rich limestone of the LST which is overlain by a massive limestone bed with rare pebbles, representing the TST (Figure 4.3). At the top of the TST limestone may be a toplap shellbed, with a planar upper surface (as with the top of the Pukenui C). 
Idealised Motifs of the Study area

Landward

Genera MOTIF

WAIPUNA MOTIF

Generalised Cycle

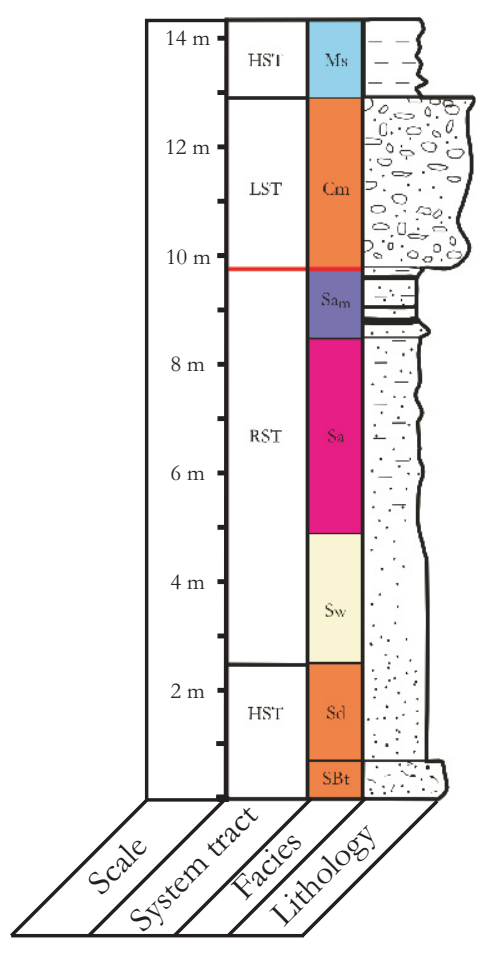

HUANGARUA MOTIF

Generalised Cycle

$\rightarrow$ Basinward

ERINGA MOTIF Generalised Cycle

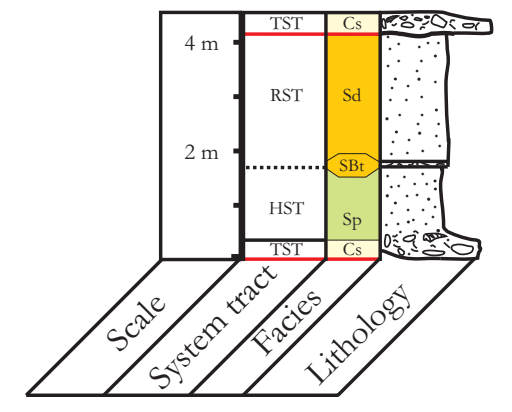

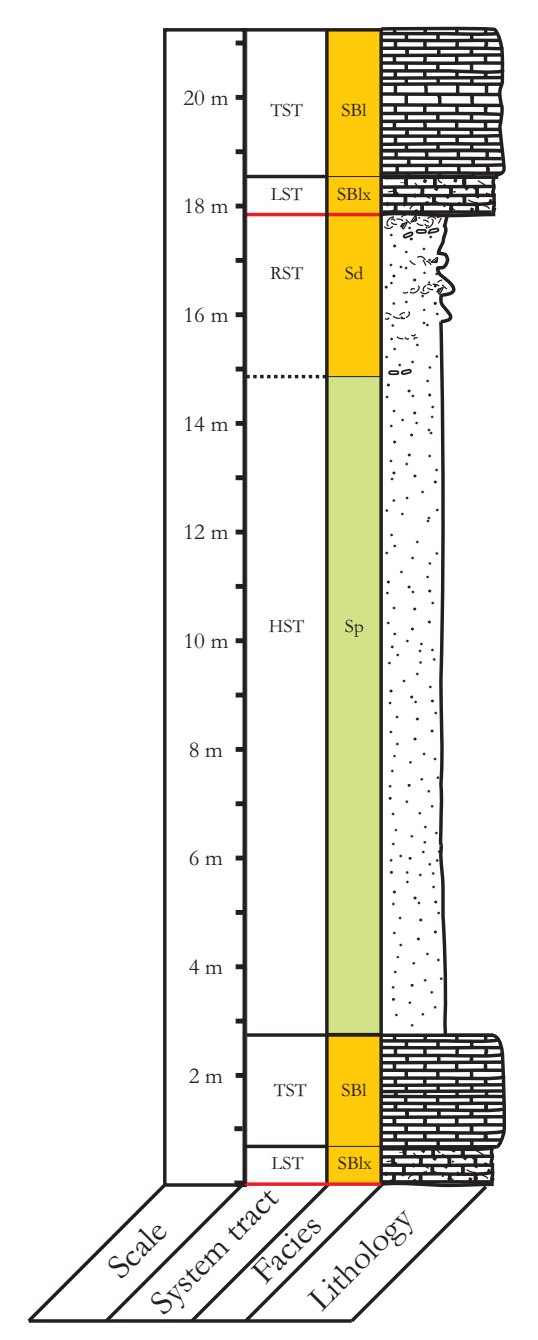

Environment Interpretation

Inner Shelf

Lower Shoreface

Shoreface

Upper Shoreface

Estuarine

Swamp

Lacustrine

Fluvial

\section{Boundaries}

Sequence

Boundary

Tract 
As the most basinward motif identified, the TST of the Eringa Motif contains a thick HST of inner to mid shelf sands, the deepest facies of the Hautotara Formation (Figure 4.2). From this bed, the succession contains no RSE, and shows a gradual shallowing through the RST.

The Eringa Motif appears to have formed at a position in the basin where the sediments are deposited at or around the wave base of the LST. This motif occurs in the lower Hautotara Formation along the Windy Peak monocline, and is particularly well exposed at the Ruawaka Measured Section.

\subsubsection{Motif Two: Huangarua Motif}

The Huangarua Motif is the most common cyclothem type identified in the Hautotara Formation, and largely occurs in the middle to upper Hautotara Formation. The Huangarua Motif is named after the Huangarua Cyclothem of Vella (1963a), which corresponds to the entire Hautotara Formation at the type section. A variation of the Huangarua Motif is identified at the Hinakura Road section, and is also discussed.

The base of this motif is effectively at the base of the TSE, which has eroded the underlying LST (Figure 4.3). The gravels of the TST are inferred to have come from fluvial conglomerate deposited during the preceeding LST, and as relative sea-level rose, this material is reworked in the high energy shoreface setting. Overlying the shelly conglomerate are inner shelf to lower shoreface HST and RST sandstones and shellbeds with no discernable boundary between the two systems tracts.

The Huangarua Motif is thin, often between 4 to 15 metres, and represents a more landward setting than the Eringa Motif (Figure 4.3). The Huangarua Motif is common in the Hautotara Formation along the western limb of the Windy Peak Anticline, and also occurs in the Ruakokoputuna Valley. 
The Hinakura Road section contains a cycle within the Hautotara Formation that contains numerous characteristics of the Huangarua Motif. Importantly however, a lack of gravels within the depositional setting at this site means parts of this motif are not appropriate for the cycle. The HST and LST of the Hinakura Road cycle are comparable to the Huangarua Motif identified elsewhere, however, the TST is represented by beachface sandstones as opposed to beachface reworked gravels, and no TSE is observed. Below the TST is the LST, represented by the backbeach/lagoonal mudstone. This part of the Hinakura Road section is believed to have been influenced by a combination of palaeogeographic setting and tectonism causing a lagoon to form during the late regressive/early lowstand time, as opposed to fluvial braidplains that form in other areas at the time.

\subsubsection{Motif Three: Waipuna Motif}

The Waipuna Motif (Figure 4.3) occurs at a number of sites, and straddles the boundary between the Hautotara and Te Muna formations. The Waipuna Motif is named for the farm on which the Blue Rock Hautotara measured section is located. The outlay of the Waipuna Motif differs from the other motifs described, as it includes two cycles, from the SB at the base of the marine LST, through to the nonmarine SB above the lacustrine mudstone. The SB at the centre of the motif represents the transition from the Hautotara Formation to Te Muna Formation. The Waipuna Motif represents the final emergence of the eastern Wairarapa Valley, and contains marine and marginal marine sediments overlain by terrestrial conglomerates.

The base of the Waipuna Motif is a TSE and TST of the form previously described for the Huangarua Motif. Above this, the HST contains shoreface sands and shellbeds, and is overlain by upper shoreface sands interpreted to represent the lower RST. Above the upper shoreface sands are estuarine sandy mudstones. These estuarine sandy mudstones may be interbedded with organic rich horizons, indicating mudflats to swampy back beach regions, or gravels of a delta. The SB is the base of the LST non-marine conglomerate, which has an erosive to deformable lower contact over the estuarine sediments. Conformably on the conglomerate is the lacustrine 
mudstone of the next HST, representing a shift from marine to terrestrial sedimentation and the total emergence of the motif.

The Waipuna Motif is identified in the Blue Rock Valley, the orginal type section of the Hautotara Formation, at Big Bend, Huangarua West, and in the Whangaehu Valley. The motif is not identified at the Ruawaka Measured Section, where the contact between the Hautotara and Te Muna formations is an angular unconformity.

\subsubsection{Motif Four: Te Muna Motif}

The Te Muna Motif is the common stratigraphic architecture of the Te Muna Formation, and therefore has been named after the formation.

The cycle contains a fluvial conglomerate overlying the channelised SB, and inferred to represent deposition from the LST to the TST. Conformably overlying the conglomerate is a lacustrine mudstone of the HST, which may contain lignites, or organic rich horizons of a swamp, or fine gravels of a HST river delta (Figure 4.3).

As the base of the LST is an erosive surface, it is difficult to identify if entire cycles have been removed, although it is believed that where observed, only the top of the underlying lacustrine mudstone is eroded, and no complete cycles are eroded.

The Te Muna Motif is the most landward motif of the study (Figure 4.3), and represents a fully terrestrial response to glacio-eustatic sea level changes. This motif is identified in all areas where there are good exposures of the Te Muna Formation. The Te Muna Motif also occurs in the Ahiaruhe Formation and can be observed in recent non-marine formations of the Wairarapa Valley. 


\subsection{Architecture of Measured Sections}

\subsubsection{Hinakura Road Section}

The Hautotara Formation is poorly exposed at the Hinakura Road Section. However, one SB within the Huangarua Motif is observed. The information provided by this section may be supplemented by the work of Rampton (1997). The "H4" measured section is southwest of the Hinakura Road Section, and also passes from the Pukenui Limestone through the Hautotara Formation and into the Te Muna Formation. Here he has observed five cycles, although a basic reinterpretation of the stratigraphy provided (Figure 4.4) identifies three and a half cycles in the Hautotara Formation. Three and a half cycles appears consistent with the space available to the Hautotara Formation at the Hinakura Road Section, and the contact with the Te Muna Formation is inferred to be an angular unconformity, unlike the conformable contact of the Waipuna Motif.

The Hinakura Road Section also includes most of two cycles of the Te Muna Motif. Within the HST lacustrine mudstones are two tephra beds, allowing constraints on the timing of Te Muna Formation deposition in the north of the study area.

\subsubsection{Huangarua West Section}

The Huangarua West Section contains the Waipuna Motif, and therefore a conformable transition between the Hautotara and Te Muna formations. Within the shoreface sandstone of the RST are a number of specimens of worn estuarine macrofossils, indicating the presence of a nearby estuarine setting. The lowermost lacustrine mudstone of the Te Muna Formation contains a pair of tephra, with the lower interpreted to have been deposited 1.57 Myr. This indicates that the Hautotara to Te Muna Formation transition at the Huangarua West Section occurred around $1.58 \mathrm{Ma}$. 


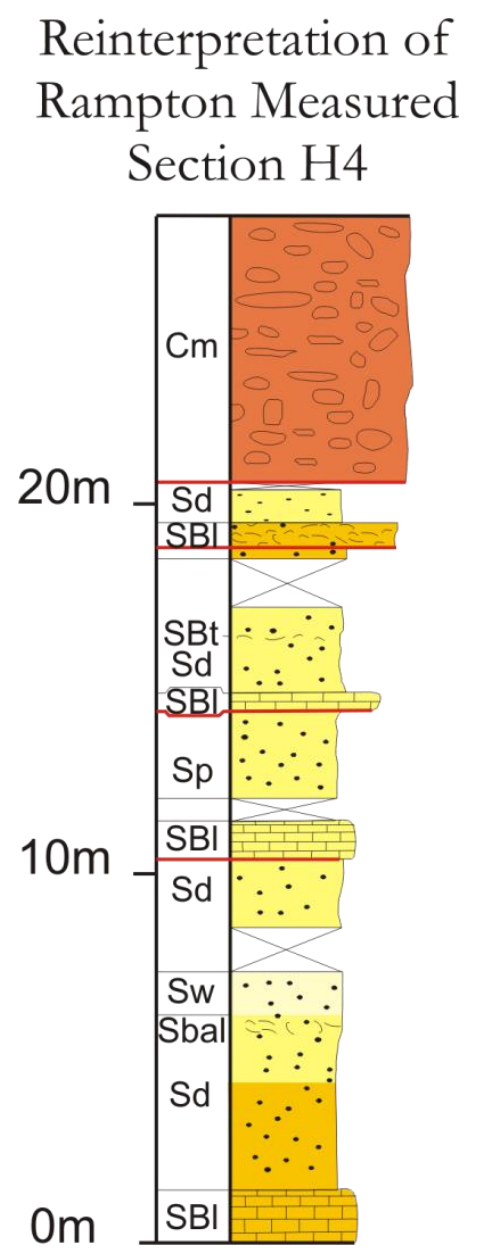

Figure 4.4 Rampton (1997) reinterpretation. Colours within stratigraphy refer to inferred depositional environment which may be seen on the legend in Figure 4.3.

\subsubsection{Ruawaka Section}

The Ruawaka Section contains nearly the entire Hautotara Formation, although the top of the formation is eroded by the overlying Te Muna Formation. The Ruawaka Section contains one full Eringa Motif, before a shallowing is observed, with six and a half cycles of the Huangarua Motif observed. The lowermost Huangarua Motif has similarities with the Eringa Motif, indicating the transition from relatively deeper water to near shore and marginal marine sedimentation. One and a half cycles of the Te Muna Motif are observed in the Te Muna Formation, and these are believed to be correlatives of Members One to Three of the type section of Collen \& Vella (1984). 
The Huangarua Motifs at the Ruawaka Section contains numerous event concentrated shellbeds (Hendy et al., 2006). These are dominated by estuarine fauna such as Austrovenus stutchburyi and Limnoperna huttoni, indicating the presence of extensive estuarine settings landward of the motif. The extinct Limnoperna huttoni is believed to have inhabited the upper parts of estuaries and also brackish lakes (Bland pers comm; Beu \& Maxwell, 1990), and as it is only found at the Ruawaka Section, this indicates this environment was restricted the area around the modern day Windy Peak.

The TST conglomerates of the Ruawaka Section, and those observed in nearby areas such as Big Bend contain an assortment of fossils. Where the thickness of the unit was sufficient, there was a clear trend to deeper water and gravel-inhabiting fauna. Some of the more fossil sparse beds also included the estuarine Austrovenus stutchburyi, indicating the TST has reworked possibly RST to LST estuarine settings.

The Ruawaka Section lacks the Waipuna Motif, with the Hautotara - Te Muna Formation contact an angular unconformity. From correlation with cycles in the Hautotara Formation, and from the Te Muna type section, this unconformity is believed to represent $0.3 \mathrm{Myr}$ (Figure 4.5).

\subsubsection{Ruakokoputuna Bridge Cliff Section}

The Ruakokoputuna Bridge Cliff Section contains one cycle of the Huangarua Motif, and one cycle of the Waipuna Motif. However, an undefined thickness of Hautotara Formation is below the base of the Ruakokoputuna Bridge Cliff Section, and therefore a number of cycles are not recorded. It appears from observations that the shallowing sequence seen between the Eringa and Huangarua Motifs at Ruawaka also occurs in the lower Hautotara Formation near the Ruakokoputuna Bridge Cliff Section. Two cycles of the Te Muna Motif are seen in the Te Muna Formation.

A number of statements in reference to the palaeogeography of the area surrounding the Ruakokoputuna Bridge Cliff Section can also be made. These include: 
1. Some cycles observed in the Pukenui Limestone contain greywacke pebbles in TST limestones, in particular the Bub's Flat Limestone (Clarke, 1998). These are interpreted to have been transported from the Aorangi Ranges to the south, the nearest source of greywacke. This region is the preferred source of greywacke pebbles to the Ruakokoputuna Valley, as although greywacke pebbles are also found in the Pukenui Limestone around the north of the study area, where greywacke highs are also present, the central region of the study area lacks these greywacke clasts until the deposition of the Te Muna Formation.

2. During deposition of the upper Hautotara Formation, this region was increasingly influenced by fluvial sedimentation during lowstands.

3. The upper Hautotara Formation at the Ruakokoputuna Bridge Cliff Section is more sheltered than the central study area (around the Ruawaka Section), evidence includes an increased prevalence of mud drapes at the Ruakokoputuna Bridge Cliff Section.

4. The major source of the fluvial gravels in the Te Muna Formation is from the Ruakokoputuna Valley to the south, with the Blue Rock Valley a minor influence.

\subsubsection{Blue Rock Race Section}

Five thin cycles of the Te Muna Motif are identified in this section. The upper cycle is not fully exposed and therefore not completely documented in the measured section. The dips of the beds shallow significantly up section, showing growth on the Blue Rock Anticline was occurring as the Te Muna Formation was being deposited.

\subsubsection{Blue Rock Hautotara Section}

The Blue Rock Hautotara Section contains the Waipuna Motif, and shows the transition between a mudflat dominated estuarine environment into the fluvial $\mathrm{Te}$ Muna Formation. Not recorded due to exposure and weathering, but immediately 
above the Te Muna Formation conglomerate is the Duggan Ash (Thompson, 1980). Correlation of major element chemistry analysis of the Duggan Ash shows it may be from an eruptive event circa 1.57 Ma meaning the transition between the Hautotara and Te Muna formations occurred circa 1.58 Ma (Nicol et al., 2002; Shane \& Froggatt, 1991).

\subsubsection{Clay Creek Section}

The Clay Creek Section represents the southernmost extent of identified Hautotara Formation, and contains one cycle that appears to have characteristics of both the Eringa and Huangarua Motifs. The well-sorted character of the sandstones and the lack of greywacke clasts show this site was some distance away from fluvial sources within a moderate to high energy wave climate.

Figure 4.5 (Following Page)

Fence diagram for measured section of the study area, including H1 and H4 of Rampton (1997).

Note: * near base of $\mathrm{H1}$ indicates where stratigraphic description precludes a definitive correlation to facies used in this study. Dashed lines with question marks indicate high level of uncertainty with correlation. 


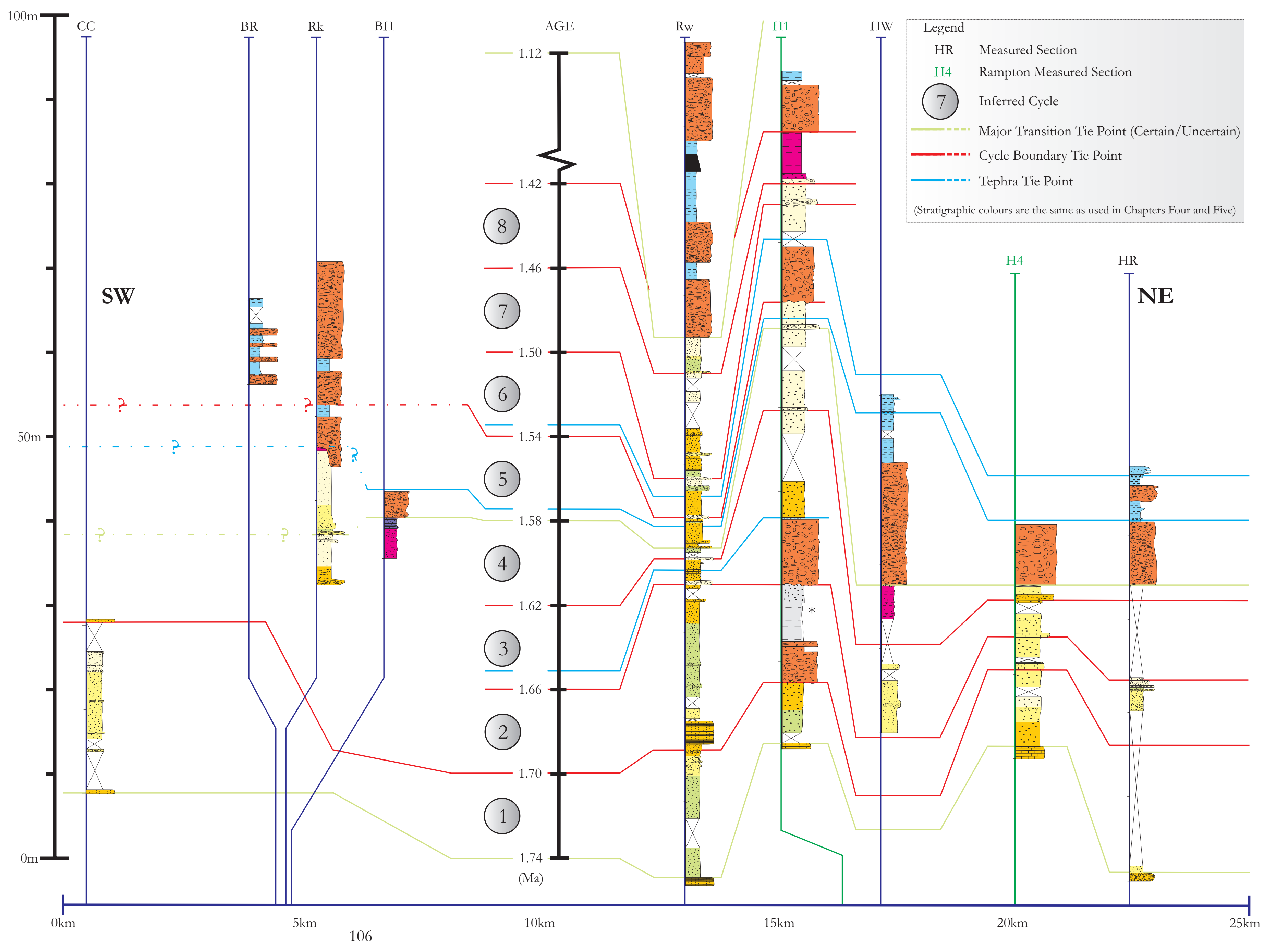




\section{Chapter Five \\ Synthesis and Palaeogeography}

\subsection{Introduction}

This chapter incorporates information documented in previous chapters, and combines this with data from previous investigations of the region, to produce a series of palaeogeographical maps to reconstruct the final emergence of the southeastern Wairarapa Valley.

Three maps are presented; the oldest shows a palaeogeographic reconstruction of the study area during deposition of the top of the Pukenui Limestone at approximately 1.73 Ma, and contains the deepest succession shown. The second map is of the RST close to the third CB in the Hautotara Formation, before many of the areas become the fully terrestrial Te Muna Formation. The last map shows the following HST around $1.57 \mathrm{Ma}$, with the lacustrine setting prominent in the study area, but Hautotara Formation still present at the centre of the study area.

Contractional structures play a major role in influencing the palaeogeography and sediment distribution in the study area. The major features are the Windy Peak and Harris Ridge Anticlines, the Huangarua and Ruakokoputuna Synclines, and the Huangarua and Dry River Faults (Figure 5.1; Appendix One). The structural evolution of the study area has previously been constrained by multiple works, in particular Lamb \& Vella (1987) and Nicol et al., (2002), with recent deformation identified by Formento-Trigilio et al., (2002). This work builds on these study's, and examines the rate of deformation during deposition of the Hautotara and Te Muna Formations.

A number of unpublished works to the north of the study area compliment field observations, and include the works of Vella (1949), Senior (1966) and Rampton (1997). Within the south of the study area, the works of Thompson (1980) and 


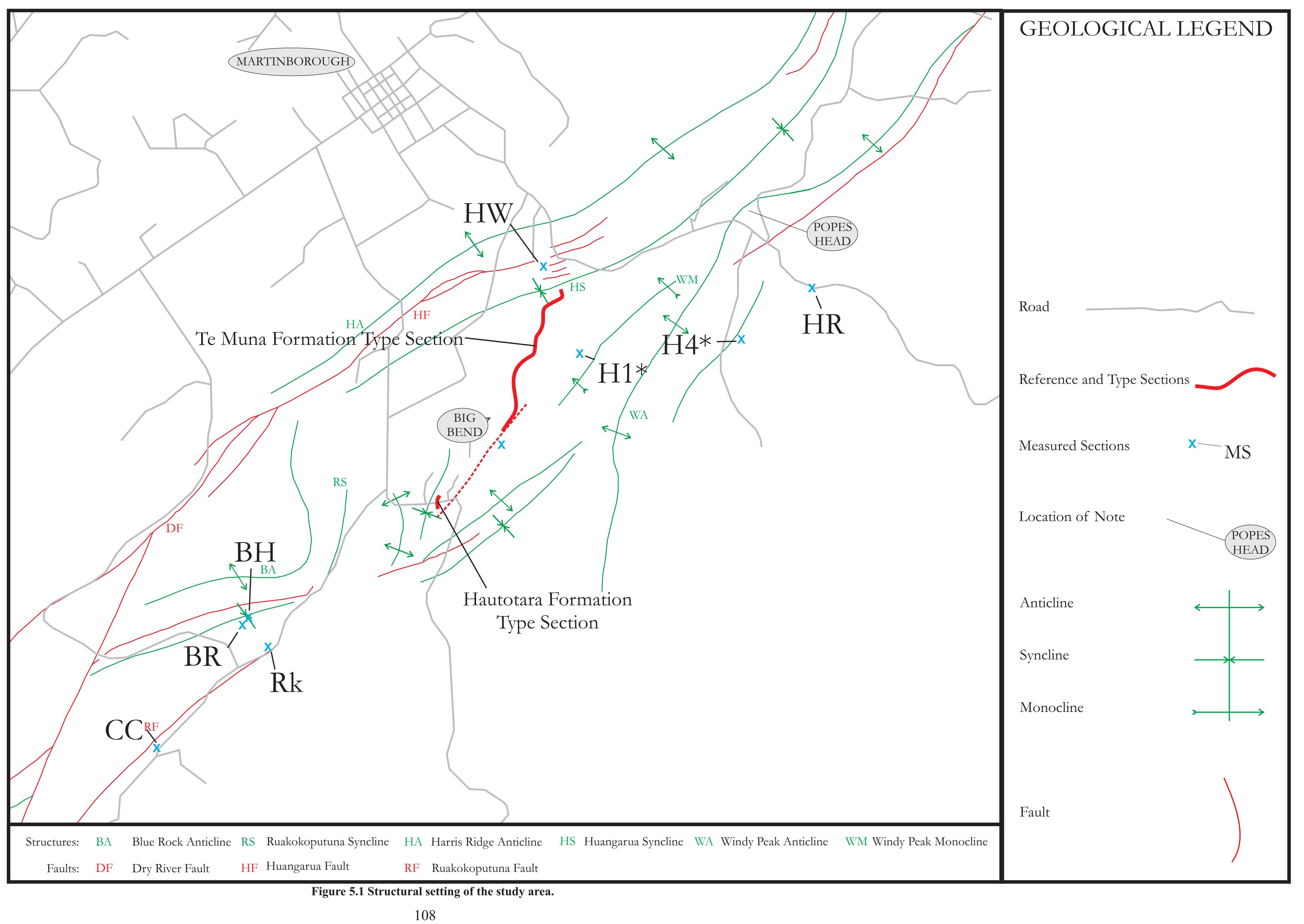


Clarke (1998) also provide insights that may be integrated with this studies information to aid palaeogeographic reconstructions. By incorporating data not limited to the immediate study area, or time span, the effects of large scale processes can be assessed.

\subsection{Reconstruction One: Top of Pukenui C, Mid Cycle One - 1.73 Ma}

The late Nukumaruan "Pukenui C" is interpreted to represent the trangressive systems tract, with the upper surface approximating the maximum flooding surface. Therefore this palaeogeographic reconstruction represents the deepest widespread environments identified in this study (Figure 5.2).

The study area is bounded by the emergent greywacke highs of the Aorangi Ranges to the southwest and the Jury Ridge to the north. To the east is the landward margin of the valley.

The Windy Peak Monocline and Anticline, along with associated folding to the east are actively growing by this time, while the Huangarua Syncline and structures to the west are not influential features at this time. Although a structural high is developing immediately north of the Blue Rock Hautotara Section $\left(\mathrm{BH}^{*}\right)$, the facies of the study area progressively deepen basinward.

East of the study area appears to be emergent during deposition of the "Pukenui C". Evidence includes the identification of the estuarine bivalve Limnoperna huttoni within some limestone beds east of the study area. However, as this region largely consists of fine grained formations and is now rounded mudstone hills, difficulties arise in making observations of this area (Vella \& Briggs, 1971).

The Pukenui Limestone is a regionally extensive formation, and the "Pukenui C" is a prominent marker horizon in the study area. Lithological variations within the "Pukenui C" reflect the variation of environments within the study area (Figure 5.2). Greywacke clasts are observed within the underlying limestones at a number of sites, although importantly, are not extensive. Outcrops with these clasts include the 


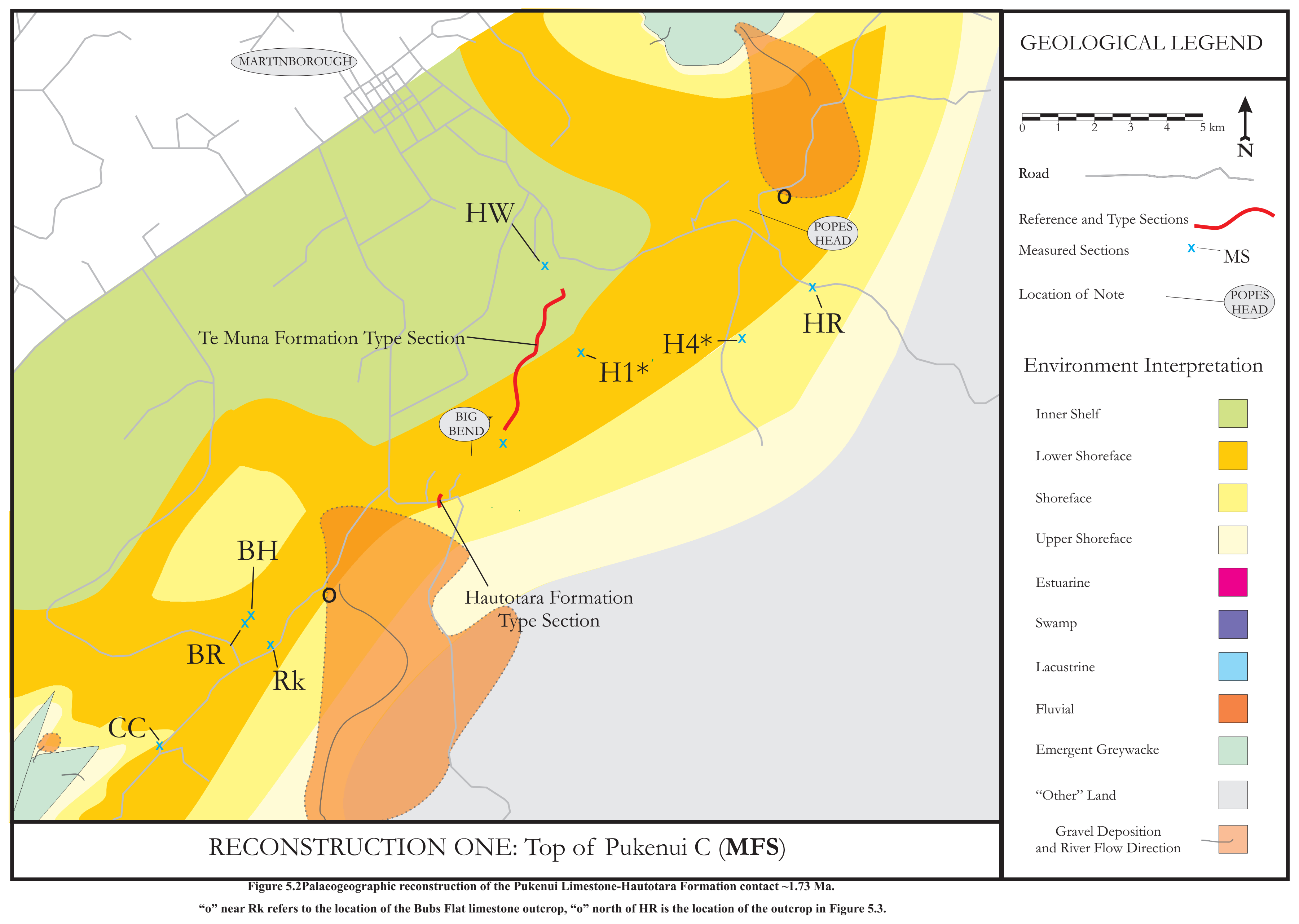


"Pukenui C" and informally named Bubs Flat limestone in the lower Ruakokoputuna Valley and the "Pukenui C" in the Whangaehu Valley north of the study area (Clarke, 1998; Senior, 1966) (Figures 5.2, 5.3). These clasts are interpreted to have been deposited by rivers draining the emergent greywacke highs of the Aorangi Ranges to the southwest and the Jury Ridge to the north, before being reworked within the shoreface zone.

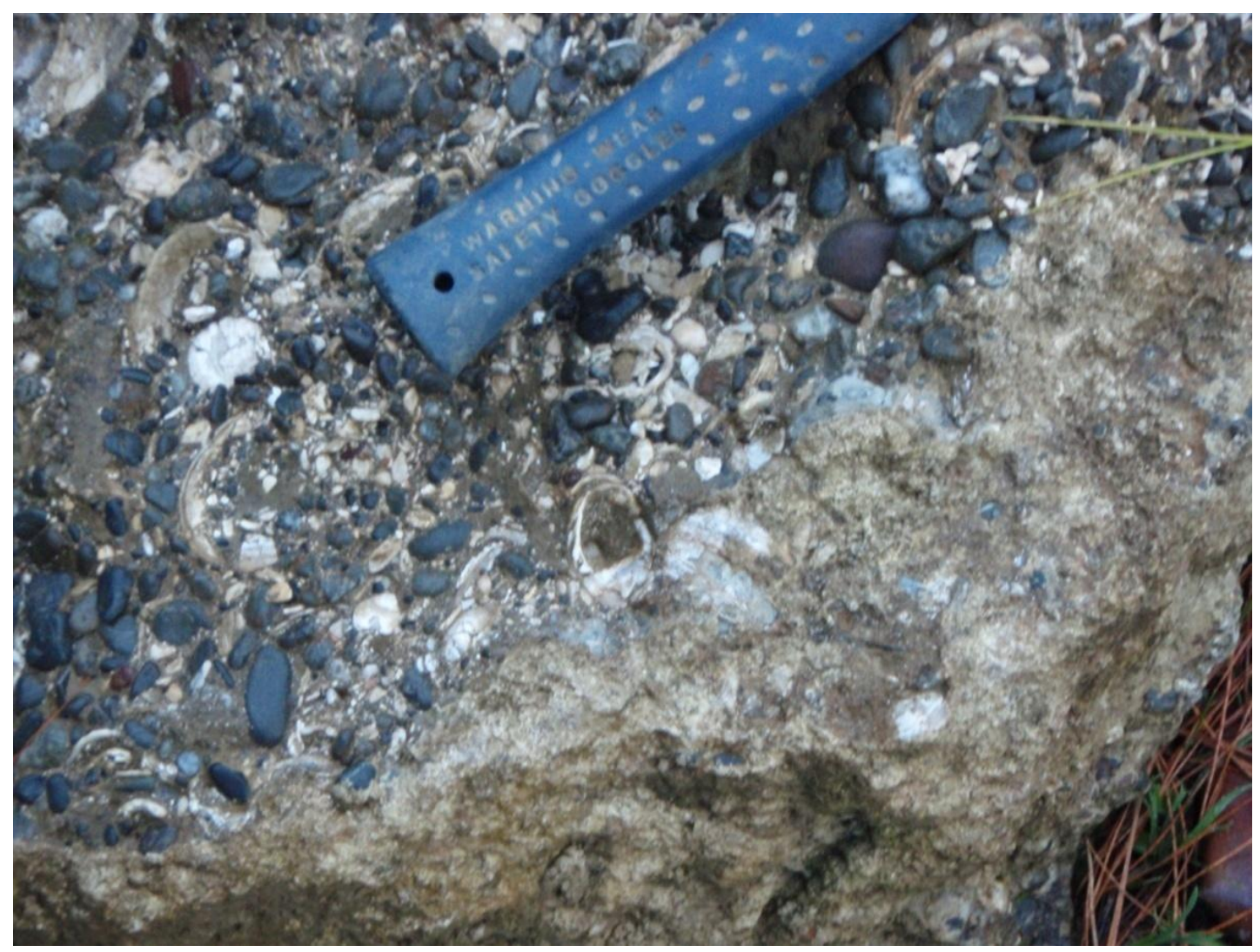

Figure 5.3 "Pukenui C" within the Whangaehu Valley, north of the study area showing rounded greywacke clasts indicating a depositional setting proximal to river systems draining greywacke highs (BQ 141 321)

At the Hinakura Road Section (HR) the "Pukenui C" is less cemented, and has a higher siliciclastic sand component than observed at sites elsewhere, and is overlain by finely bedded upper to middle shoreface sand, indicating a mid to upper shoreface environment.

\footnotetext{
*Throughout this chapter the two letter code following the section name refers to the position of the section on the Maps (Figures 5.1, 5.2, 5.4, 5.5).
} 
The Ruawaka and H4 Sections contain well cemented "Pukenui C" of the mid to lower shoreface environment. Inner shelf HST deposits overlying these sections indicate that deposition here was more basinward than at the Hinakura Road Section.

The area to the north of the Blue Rock Hautotara Section (BH) is believed to be a sediment starved, current swept high during the deposition of the "Pukenui C". This area is a greywacke block overlain by gravelly sands and limestones, and although the Pukenui Limestone is not present, the fauna of this area appears to be an equivalent depth to that of the Pukenui Limestone (Thomson, 1980).

Although no outcrops of the "Pukenui C" are identified around the Huangarua West Section $(\mathrm{HW})$, it is inferred that this area represents inner shelf sedimentation (Figure 5.2). Observations of the Pukenui Limestone indicate that this area is basinward, and deeper, than outcrops to the east (Rampton, 1997).

\subsection{Reconstruction Two: Late Cycle Four $-\sim 1.58 \mathrm{Ma}$}

Deposition of the Hautotara Formation strongly reflects the structural evolution of the study area. The reconstruction in Figure 5.4 is part way through the Hautotara Formation, during the RST to LST of Cycle 3, as the marine influence on the study area decreases, and immediately before onset of Te Muna Formation sedimentation in the north and south of the study area.

The greywacke highs recorded in the preceding reconstruction have become more prominent features, and continue to be the primary source of the fluvially-derived gravels during deposition of the Hautotara Formation. However, as exhibited by exotic clasts within transgressive conglomerates, these proximal locations are not the only sources of gravels (Figure 5.4). The Windy Peak Anticline and Monocline are continuing to grow, while the Dry River, Huangarua and Ruakokoputuna Faults, and the Huangarua Syncline to the east are now affecting sedimentation. Palaeogeography is now more complicated than during deposition of the "Pukenui C". 


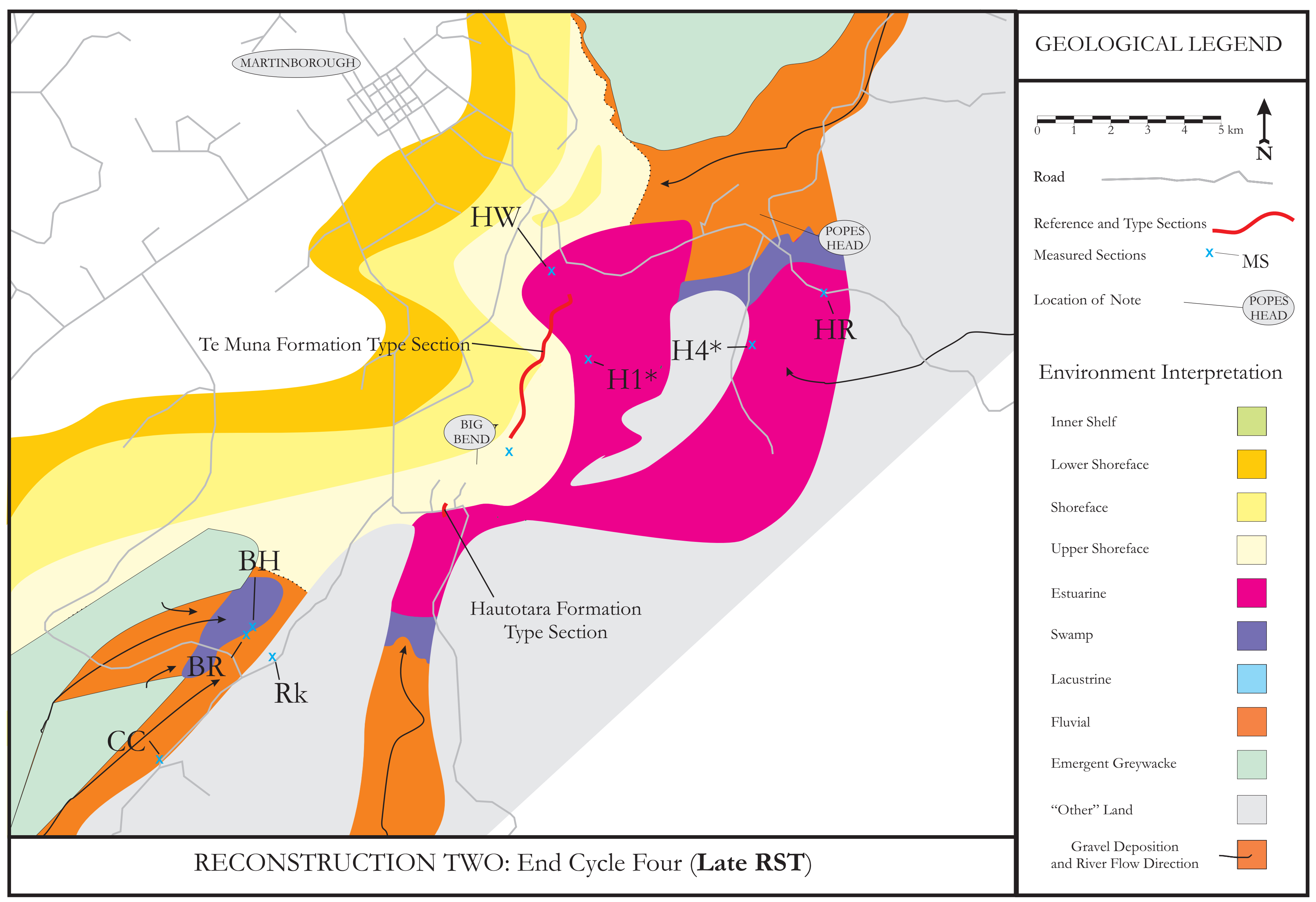

Figure 5.4 Palaeogeographic reconstruction of $\sim 1.58$ Ma. Western and eastern settings some distance from the study area are not included (areas without fill) 
Rivers are transporting gravels from greywacke highs to the north of the study area, although the continued growth of the Windy Peak Anticline (Figure 5.1) appears to limit this deposition to the northeast. To the south, the structural high to the north of the Blue Rock Hautotara Section (BH) is now fully emergent, while fluvial transportation from early Cenozoic sediments to the southeast is also inferred (Figure $5.4)$.

A range of estuarine environments are believed to be prominent features landward of the outcrops observed. Throughout the Ruawaka Section (RW) are AustrovenusLimnoperna dominated shellbeds that are inferred to represent storm outwash from estuaries. The presence of the mussel Limnoperna huttoni in these beds possibly implies a harder substrate than the Barytellina crassidens dominated sandstones at the Hautotara Type Section and the Huangarua West Section (HW) (Figure 5.1). As the structural high to the north of the Blue Rock Hautotara Section $(\mathrm{BH})$ is now fully emergent, estuarine to swampy settings have formed within the Blue Rock Valley (Figure 5.4). Lagoons formed around the Hinakura Road Section during previous Hautotara Formation RSTs, although the RST of Cycle Four is not exposed at this site, it is believed this has occurred again. The presence of the gastropod Zeacumantus lutulentus in the estuarine sandstone of the Blue Rock Hautotara Section indicates this area contains mudflats, while the Huangarua West and Hinakura Road sections also contain this gastropod in SBal shellbeds, indicating nearby mudflats (Figure 5.4).

The Ruawaka and H1 Sections are open beachface settings during this reconstruction. As the conglomerates within these sections are thin, it is believed the fluvial gravels of the LST were not deposited at these sites. Instead it appears likely these clasts were transported to these sites by longshore drift during transgressions. Fluvial deposition has occurred within previous Hautotara Formation cycles at the H1 Section. 


\subsection{Reconstruction Three: Cycle Five $-\sim 1.57 \mathrm{Ma}$}

The early cycles of the Te Muna Formation are characterised by lacustrine deposits with multiple tephra (Figure 5.5).

The continued growth of the Huangarua Syncline, Harris Ridge Anticline, and the Huangarua Fault within the northwestern study area are influencing deposition at the time represented by this reconstruction (Figure 5.5). Highstand deposits of the Te Muna Formation are characterised by lower fluvial sediment yields, and low energy lacustrine deposition (Woolfe, 1993).

Although more localised, the lacustrine systems of the lower Te Muna Formation appear comparable to the modern day Lake Wairarapa. It is inferred that two lake systems to the north and south of the study area are bound by reworked fluvial gravels deposited during the preceding LST, and reworked during the following transgression (Figure 5.5).

The patchy tephra record at this time could be as a result of depositional processes or infer that these lakes would shift position within the valleys, although subaerially exposed surfaces have not been observed at the measured sections in this study. Organics and coarse lenses within the lacustrine units of the Hinakura Road Section imply this section is near a lake shore (Figure 5.5).

The sandstones of the Ruawaka and H1 Sections represent a shallow marine environment within an embayment, and this restricted region of Hautotara Formation deposition continues until around 1.45 Ma, when estuarine conditions are recorded at H1. 


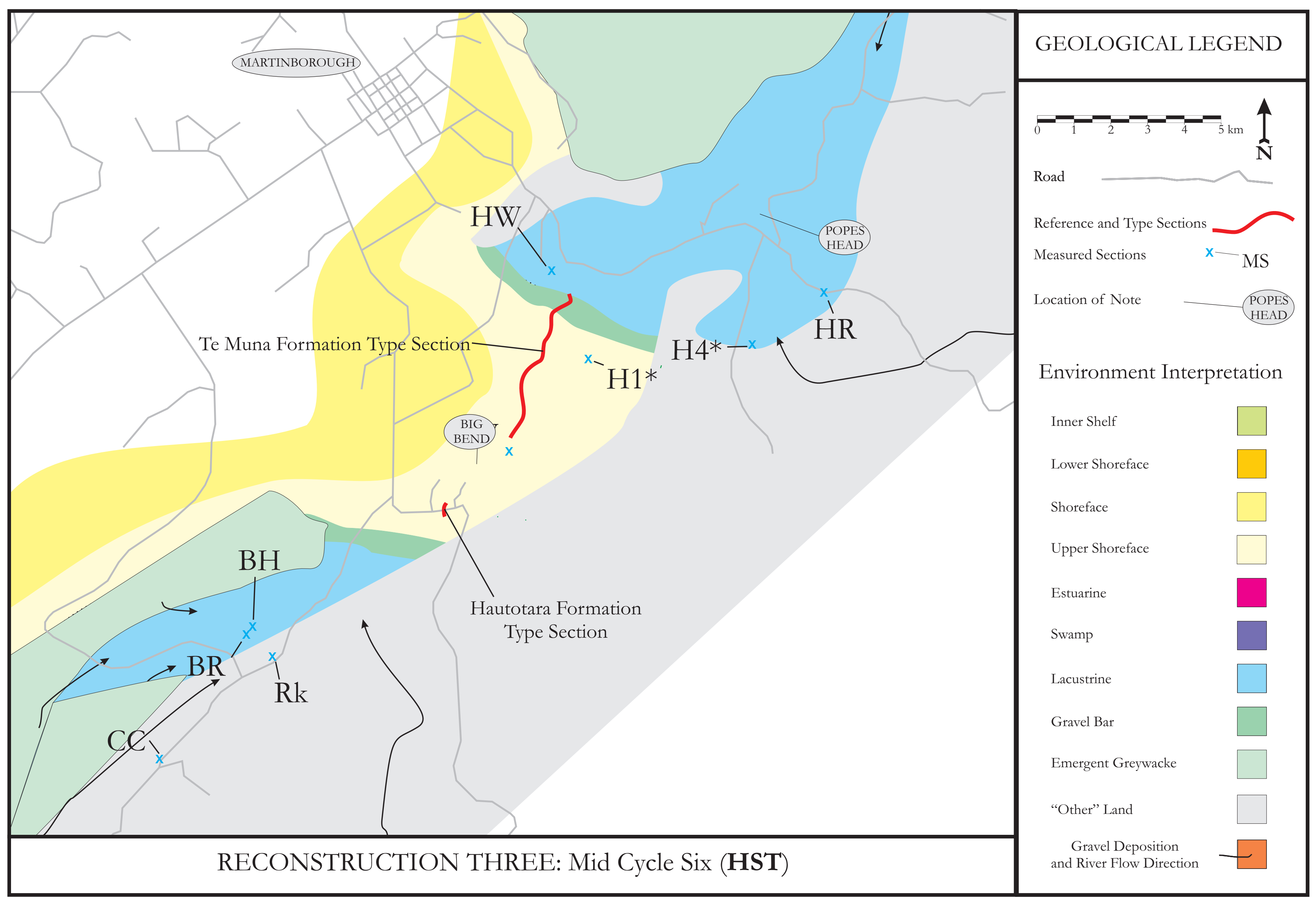

Figure 5.6 Palaeogeographic reconstruction of $\sim 1.57$ Ma. Western and eastern settings some distance from the study area are not included (areas without fill) 


\section{Chapter Six \\ Conclusions}

\subsection{Major Findings}

This study has provided a comprehensive re-evaluation of the final emergence of the eastern Wairarapa Valley. The major findings and outputs of this study are a result of a combination of field observations, lab analysis and synthesis of previous work.

Three major aims were clearly outlined within the introduction to this study (Chapter One). Here an assessment is made of how this study has achieved each of these aims.

\section{Aim One: \\ Produce revised ages for the Hautotara and Te Muna Formations.}

A revised age for the Hautotara Formation is presented in this study, here it is suggested deposition occurred between 1.73 Ma to sometime after 1.42 Ma.

This age range is derived from a combination of:

Biostratigraphic data. The first occurrence of the coccolith Gephyrocapsa sinuosa is dated at $1.80 \mathrm{Ma}$, and occurs in the "A-B Interbed" of the underlying Pukenui Limestone (Edwards 1976; Nicol et al., 2002). The base of the Hautotara Formation must be younger than this, and it is interpreted that the contact is between one and two $40 \mathrm{kyr}$ cycles above the first occurrence of Gephyrocapsa sinuosa. This provides an estimated age of $1.73 \mathrm{Ma}$ for the top of the Pukenui Limestone. 
Cyclostratigraphic correlations. Eight $40 \mathrm{kyr}$ cycles are identified within the Hautotara Formation (see Aim Two, below), suggesting the deposition between 1.73 and $1.42 \mathrm{Ma}$.

Tephrochonological data: Tephra within the oldest sediments of the Te Muna Formation is dated $\sim 1.6 \mathrm{Ma}$, constraining the maximum age of the Te Muna Formation to around this time.

A revision of the character of the Hautotara-Te Muna Formation contact suggests the contact between the formations is diachronous, with the Te Muna Formation being conformably deposited from 1.58 Ma in the north and south of the study area, while the base of the type section (in the centre of the study area) is an angular unconformity over $9^{\circ}$, with deposition above this commencing at $1.12 \mathrm{Ma}$. Overall, this shows the Te Muna Formation spans the time range of 1.58 Ma to around 0.7 $0.4 \mathrm{Ma}$.

In early work (e.g. Vella \& Briggs, 1971), the upper surface of the Pukenui Limestone was placed at the top of the "Pukenui B" limestone, while the lower contact of the Hautotara Formation was 30 metres stratigraphically above the "Pukenui C", and resulting in a nomenclatural gap. This study has placed the top of the Pukenui Limestone at the top of the easily recognisable "Pukenui C" member, and bringing it in line with modern usage. As a consequence of these results, this study has also improved the age control on the Pukenui Limestone, with a new inferred age of 1.86 to $1.73 \mathrm{Ma}$.

\section{Aim Two: \\ Identify sequence stratigraphic motifs of the Hautotara and Te Muna Formations.}

Seven new, detailed stratigraphic columns of the Hautotara and Te Muna Formations have provided a detailed facies analysis of the Hautotara and Te Muna Formations, allowing the identification of glacio-eustatic sea-level cycles within the formations. Four dominant motifs are described for the Hautotara and Te Muna Formations, 
showing a basinward (Eringa Motif) to landward (Te Muna Motif) progression of environments through time. The most common motif identified in the study area is the Huangarua Motif, while the Waipuna Motif records the conformable Hautotara Te Muna Formation transition.

By incorporating East Coast Basin sequence stratigraphic methods, eight cycles are observed within the Hautotara Formation at the Ruawaka Section. Three and a half cycles are observed in the Hautotara Formation in the northern part of the study area, before Te Muna Formation rocks $\sim 1.6 \mathrm{Ma}$ are deposited in this area, supporting the idea of diachroneity.

A simple mechanism for cyclicity in the non-marine Te Muna Formation is identified, in which the lacustrine units represent the highstand systems tract, while the fluvial conglomerates represent the other three systems tracts.

\section{Aim Three: \\ Present the Early Quaternary marine to terrestrial transition of the Eastern Wairarapa Valley, through palaeogeographical reconstructions.}

Three palaeogeographic reconstructions are presented in Chapter Five, and these show the final emergence of the Eastern Wairarapa Valley. Importantly, the transition has been identified as more complex as originally thought, with deposition of the marginal-marine Hautotara Formation persisting within the central part of the study area well after the initiation of the non-marine Te Muna Formation sediments elsewhere in the basin.

These palaeogeographic reconstructions of the Hautotara and Te Muna formations demonstrate how closely related sedimentation pattern are to structural growth. For example, the evolution of a structural high north of the Blue Rock Hautotara Section (from a current-swept marine setting, to a topographic feature affecting non-marine deposition) can be observed. 


\subsection{Future Work}

Using clay analysis, Rataul (1988) identified no marine influence in the lacustrine units of the Te Muna Formation at the type section. However, this study has shown the units analysed by Rataul (1988) to have been deposited $0.3 \mathrm{Ma}$ after the final emergence of the area. Future analysis of the lower Te Muna Formation lacustrine for a marine influence would appear to be appropriate.

Numerous studies have documented the various tephra of the Hautotara and Te Muna Formations, although the site locations and stratigraphic position have been recorded with varying levels of accuracy. A continuation of this study is providing a comprehensive review of these beds, including using trace element data to allow comparison with a well constrained continuous offshore record (e.g. Allan et al., 2008).

Recent work in the East Coast Basins (e.g. Bland et al., 2004; Bland, 2006; this study) have provided a framework for the re-examination of the cyclicity observed in the Pukenui Limestone. Likewise, although it is outside the scope of this study it is hoped that information provided here, in combination with work in the Wanganui and Hawke's Bay Basins, can further constrain the Plio-Pleistocene palaeogeographic history of the lower North Island. 


\section{References}

Abbott, S. T., \& Carter, R. M. (1994). The sequence architecture of midPleistocene (c. 1.1-0.4 Ma) cyclothems from New Zealand: facies development during a period of orbital control on sea-level cyclicity. Orbital forcing and cyclic sequences. International Association of Sedimentologists special publication, 19, 367-394.

Abbott, S. T., Naish, T. R., Carter, R. M., \& Pillans, B. J. (2005). Sequence stratigraphy of the Nukumaruan Stratotype (Pliocene-Pleistocene, c. 2.081.63 Ma), Wanganui Basin, New Zealand. Journal-Royal Society Of New Zealand, 35(1/2), 123.

Allan, A. S. (2008). An elemental and isotopic investigation of Quaternary silicic Taupo Volcanic Zone tephras from ODP Site 1123: chronostratigraphic and petrogenetic applications. (Unpublished M.Sc. thesis). Wellington: Victoria University of Wellington.

Allan, A. S., Baker, J. A., Carter, L., \& Wysoczanksi, R. J. (2008). Reconstructing the Quaternary evolution of the world's most active silicic volcanic system: insights from an 1.65 Ma deep ocean tephra record sourced from Taupo Volcanic Zone, New Zealand. Quaternary Science Reviews, 27(25-26), 2341-2360.

Alloway B. V., Pillans B. J., Naish T. R., Westgate J. A., (2004a). Age and correlation of Ototoka tephra. Appendix in Molluscan biostratigraphy of oxygen isotope stages of the last 2 million years in New Zealand. Part 1. Revised generic positions and recognition of warm- and cool-water migrants. Journal of the Royal Society of New Zealand, 34: 261-265. 
Alloway B. V., Westgate J. A., Pillans B.J., Pearce N., Newnham R., Byrami M., Aarburg, S. (2004b). Stratigraphy, age and correlation of middle Pleistocene silicic tephras in the Auckland region, New Zealand: a prolific distal record of TVZ volcanism. New Zealand Journal of Geology and Geophysics 47: 447-479.

Andrews, K. (2001). The Depositional Environment of the Pukenui Limestone, in the Hinakura Road area, Southern Wairarapa, New Zealand (Unpublished B.Sc. Honours thesis). Victoria University of Wellington.

Atkins, C. B. (1995). The Depositional Environment of the Pukenui "A" Limestone (Unpublished B.Sc. Honours thesis). Victoria University of Wellington.

Bates, T. E. (1967). The Geology of the Northern Aorangi Range and Part of Palliser Bay; Sheet N165 (Unpublished M.Sc. thesis). Victoria University of Wellington.

Beanland, S.; Melhuish, A.; Nicol, A.; Ravens, J., 1998: Structure and deformational history of the inner forearc region, Hikurangi subduction margin, New Zealand. New Zealand Journal of Geology and Geophysics 41. 325-342.

Begg, J. G., \& Johnston, M. R. (2000). Geology of the Wellington area. 1: 250 000 geological map 10. Institute of Geological and Nuclear Sciences, Lower Hutt, New Zealand.

Berger, G. W., Pillans, B. J., \& Palmer, A. S. (1992). Dating loess up to $800 \mathrm{ka}$ by thermoluminescence. Geology, 20(5), 403. 
Beu, A. G.; Grant-Taylor, T. L.; Hornibrook, N. de. B., 1980: The Te Aute limestone facies, Poverty Bay to northern Wairarapa. Department of Scientific and Industrial Research, Wellington, New Zealand. 36 p.

Beu, A. G., \& Maxwell, P. A. (1990). Cenozoic Mollusca of New Zealand. New Zealand Geological Survey Paleontological Bulletin, 58, 518p.

Beu, A. G. (1995). Pliocene limestones and their scallops: lithostratigraphy, pectinid biostratigraphy, and paleogeography of eastern North Island late Neogene limestone. Institute of Geological \& Nuclear Sciences Monograph 10. Lower Hutt, New Zealand. Institute of Geological \& Nuclear Sciences. 243 p.

Beu, A. G. (2001). Local stages to be used for the Wanganui Series (PliocenePleistocene), and their means of definition. New Zealand Journal of Geology and Geophysics, 44(1), 113-126.

Beu, A. G. (2006). Marine Mollusca of oxygen isotope stages of the last 2 million years in New Zealand. Part 2. Biostratigraphically useful and new Pliocene to Recent bivalves. Journal of the Royal Society of New Zealand, 36(4), 151-338.

Bland, K. J., Kamp, P. J., \& Nelson, C. S. (2004). Stratigraphy and development of the Late Miocene-Early Pleistocene Hawke's Bay forearc basin. In Proceedings of New Zealand Petroleum Conference (pp. 7-10).

Bland, K. J. (2006). Analysis of the Central Hawke's Bay Sector of the Late Neogene Forearc Basin, Hikurangi Margin, New Zealand (Unpublished Ph.D. thesis). University of Waikato.

Browne, G. H., \& Naish, T. R. (2003). Facies development and sequence architecture of a late Quaternary fluvial-marine transition, Canterbury 
Plains and shelf, New Zealand: implications for forced regressive deposits. Sedimentary Geology, 158(1-2), 57-86.

Bussell, M. R., \& Pillans, B. (1992). Vegetational and climatic history during oxygen isotope stage 9, Wanganui district, New Zealand, and correlation of the Fordell Ash. Journal of the Royal Society of New Zealand, 22(1), $41-60$.

Cande, S. C., \& Kent, D. V. (1995). Revised calibration of the geomagnetic polarity timescale for the Late Cretaceous and Cenozoic: Journal of Geophysical Research. B, Solid Earth and Planets, 100(4), 6093-6095.

Cape, C. D., Lamb, S. H., Vella, P., Wells, P. E., \& Woodward, D. J. (1990). Geological structure of Wairarapa Valley, New Zealand, from seismic reflection profiling. Journal of the Royal Society of New Zealand, 20(1), $85-105$.

Caron, V., Nelson, C. S., \& Kamp, P. J. (2004). Transgressive surfaces of erosion as sequence boundary markers in cool-water shelf carbonates. Sedimentary Geology, 164(3-4), 179-189.

Carter, R. M., \& Naish, T. R. (1999). The high-resolution, chronostratigraphic and sequence stratigraphic record of the Plio-Pleistocene, Wanganui Basin, New Zealand. Institute of Geological \& Nuclear Sciences Folio Series, 2.

Clarke, D. (1998). A Biostratigraphic Investigation of the Pukenui Limestone Formation, South Wairarapa, New Zealand: [a Thesis] Submitted for the Degree of Master of Science in Geology, Victoria University of Wellington (Unpublished M.Sc. thesis). Victoria University of Wellington. 
Collen, J. D., \& Vella, P. (1984). Hautotara, Te Muna and Ahiaruhe Formations, middle to late Pleistocene, Wairarapa. New Zealand. Journal of the Royal Society of New Zealand, 14, 297-317.

Couper, R. A. (1948). The geology of Makara and Ruakokoputuna Valleys, East Wairarapa (Unpublished M.Sc. thesis). Victoria University of Wellington.

Crawford, J. C. (1870). On the geology of the province of Wellington. Transactions of the N.Z. Institute, 2, 341-360.

Dobbie, W. A. (1982). Sedimentology and diagenesis of the Pukenui Limestone Formation, Wairarapa, New Zealand (Unpublished M.Sc. thesis). Victoria University of Wellington.

Dunbar, G. B., \& Barrett, P. J. (2005). Estimating palaeobathymetry of wavegraded continental shelves from sediment texture. Sedimentology, 52(2), $253-269$.

Edwards, A. R. (1976). Gephyrocapsa and the Plio-Pleistocene boundary in the New Zealand region. In Geological Society of New Zealand, Hamilton Conference, December, 1976. Abstracts, 2 p.

Edwards, A. R. (1987). An integrated biostratigraphy, magnetostratigraphy and oxygen isotope stratigraphy for the late Neogene of New Zealand. New Zealand Geological Survey, Dept. of Scientific and Industrial Research.

Erdman, C. F.; Kelsey, H. M., 1992: Pliocene and Pleistocene stratigraphy and tectonics, Ohara Depression and Wakarara Range, North Island, New Zealand. New Zealand Journal of Geology and Geophysics 35. 177-192.

Formento-Trigilio, M. L., Burbank, D. W., Nicol, A., Shulmeister, J., \& Rieser, U. (2002). River response to an active fold-and-thrust belt in a convergent 
margin setting, North Island, New Zealand. Geomorphology, 49(1-2), $125-152$.

Gammon, P. (1995). Hautotara Formation, Mangaopari Basin, New Zealand: record of a cyclothemic Pliocene-Pleistocene marine to nonmarine transition. New Zealand Journal of Geology and Geophysics, 38, 471482.

Gammon, P. R. (1997). Sequence stratigraphy of Mangaopari Basin, southeastern North Island, New Zealand (Unpublished Ph.D. thesis). James Cook University of North Queensland.

Gibbard, P. L., Head, M. J., Walker, M. J., et al. (2009). Formal ratification of the Quaternary System/Period and the Pleistocene Series/Epoch with a base at $2.58 \mathrm{Ma}$.

Haywick, D. W. (2000). Recognition and distinction of normal and forced regression in cyclothemic strata: a Plio-Pleistocene case study from eastern North Island, New Zealand. Sedimentary responses to forced regressions, 193.

Hector, J. (1884). Progress report 1884. New Zealand Geological Survey reports of geological explorations during 1883-84, 84.

Hendy, A. J. W.; Kamp, P. J. J.; Vonk, A. J., 2006: Cool water shell bed taphofacies from Miocene-Pliocene shelf sequences in New Zealand: utility of taphofacies in sequence stratigraphic analysis. In: Cool water Carbonates: Depositional Systems and Palaeoenvironmental Controls. (Ed. Pedley, H. H.; Carannate, G.). Geological Society, London, Special Publications 255. The Geological Society of London. Pp. 283-305.

Hollis, C. J., Beu, A. G., Crampton, J. S., Crundwell, M. P., Morgans, H. E. G., 
Raine, J. I., Jones, C. M., et al. (2010). Calibration of the New Zealand Cretaceous-Cenzoic Timescale to GTS2004. Calibration of the New Zealand Cretaceous-Cenzoic Timescale to GTS2004.

Hunt, D.; Tucker, M. E., 1992: Stranded parasequences and the forced regressive wedge systems tract: Deposition during base level fall. Sedimentary Geology 81. 1-9.

Kennett, J. P. (1964). A Pleistocene anticline at Gladstone, Wairarapa. New Zealand Journal of Geology and Geophysics, 7, 561-572.

Kennett, J. P., Watkins, N. D., \& Vella, P. (1971). Paleomagnetic chronology of Pliocene-early Pleistocene climates and the Plio-Pleistocene boundary in New Zealand. Science, 171(3968), 276.

Kidwell, S. M., 1991: Condensed deposits in siliciclastic sequences: expected and observed features. In: Cycles and Events in Stratigraphy (Ed. Einsele, G.; Ricken, W.; Seilacher, A.). Springer-Verlag, Heidelberg. Pp. 682-695.

King, L. C. (1933). Tertiary molluscan faunas from the southern Wairarapa. In Trans. NZ Inst (Vol. 63, pp. 334-354).

Kondo, Y.; Abbott, S. T.; Kitamura, A.; Kamp, P. J. J.; Naish, T. R.; Kamataki, T.; Saul, G. G., 1998: The relationship between shellbed type and sequence architecture: examples from Japan and New Zealand. Sedimentary Geology 122. 109-127.

Lamb, S. (1987). Archean synsedimentary tectonic deformation-A comparison with the Quaternary. Geology, 15(6), 565.

Lamb, S. H., \& Vella, P. (1987). The last million years of deformation in part of the New Zealand plate-boundary zone. Journal of Structural Geology, 9(7), 877-891. 
Lee, J. M.; Begg, J.G. (compilers), 2002: Geology of the Wairarapa area. Institute of Geological and Nuclear Sciences 1:250 000 geological map 11. Lower Hutt, New Zealand. Institute of Geological and Nuclear Sciences Ltd. 1 sheet +66 p.

Little, T., Van Dissen, R., Schermer, E., \& Carne, R. (2009). Late Holocene surface ruptures on the southern Wairarapa fault, New Zealand: Link between earthquakes and the uplifting of beach ridges on a rocky coast. Lithosphere, 1(1), 4-28.

McIntyre, A. P., 2002: Geology of Mangapanian (Late Pliocene) strata, Wanganui Basin: Lithostratigraphy, Paleontology and Sequence Stratigraphy. Unpublished $\mathrm{PhD}$ thesis, The University of Waikato, Hamilton, New Zealand. 431 p.

McKay, A. (1878). Report on the East Wairarapa District. Report Geological Exploration, 11, 14-24.

McKay, A. (1879). Report on the Southern Part of East Wairarapa District. Report Geological Exploration, 12, 75-86.

McKnight, D. G. (1969). Infaunal benthic communities of the New Zealand continental shelf. New Zealand Journal of Marine and Freshwater Research, 3(3), 409-444.

Naish, T., \& Kamp, P. J. (1997). Sequence stratigraphy of sixth-order (41 ky) Pliocene-Pleistocene cyclothems, Wanganui Basin, New Zealand: a case for the regressive systems tract. Geological Society of America Bulletin, 109(8), 978.

Naish T, Abbott ST, Alloway BV, Beu AG, Carter RM, Edwards AR, Journeaux TJ, Kamp PJJ, Pillans BJ, Saul G, Woolfe KJ (1998). Astronomical 
calibration of a Southern Hemisphere Plio-Pleistocene reference section, Wanganui Basin, New Zealand. Quaternary Science Reviews 17: 695710.

Naish, T. R. (2005). Preface: New Zealand's shallow-marine record of PliocenePleistocene global sea-level and climate change. Journal of the Royal Society of New Zealand, 35, 1-8.

Nelson, C. S., Hendy, I. L., Neil, H. L., Hendy, C. H., \& Weaver, P. P. E. (2000). Last glacial jetting of cold waters through the Subtropical Convergence zone in the Southwest Pacific off eastern New Zealand, and some geological implications. Palaeogeography, Palaeoclimatology, Palaeoecology, 156(1-2), 103-121.

Nelson, C. S., Winefield, P. R., Hood, S. D., Caron, V., Pallentin, A., \& Kamp, P. J. (2003). Pliocene Te Aute limestones, New Zealand: expanding concepts for cool-water shelf carbonates. New Zealand Journal of Geology and Geophysics, 46(3), 407-424.

Nicol, A., \& Van Dissen, R. (1997). A reassessment of abruptly fanning bed dips on the northwestern limb of the Huangarua Syncline, Wairarapa, New Zealand. New Zealand Journal of Geology and Geophysics, 40, 257-260.

Nicol, A., Van Dissen, R., Vella, P., Alloway, B., \& Melhuish, A. (2002). Growth of contractional structures during the last 10 my at the southern end of the emergent Hikurangi forearc basin, New Zealand. New Zealand Journal of Geology and Geophysics, 45(3), 365-386.

Nummedal, D.; Swift, D. J. P., 1987: Transgressive stratigraphy at sequencebounding unconformities: some principles derived from Holocene and Cretaceous examples. In: Sea-level fluctuation and coastal evolution 42. 
(Ed. Nummedal, D.; Pilkey, O. H.; Howard, J. D.). SEPM Special Publication. Pp. 358-370.

O'Brien, C. M. (1980). The stratigraphy, petrography and glass chemistry of some mid to late Pleistocene tephras, eastern Wairarapa. (Unpublished B.Sc. Honours thesis). Victoria University of Wellington.

Orpin, A. R., Gammon, P. R., Naish, T. R., \& Carter, R. M. (1998). Modern and ancient Zygochlamys delicatula shellbeds in New Zealand, and their sequence stratigraphic implications. Sedimentary Geology, 122(1-4), $267-284$.

Perrett, T. L. (1990). Variations in sediment texture and biota off a wave dominated coast, Peka Peka beach, New Zealand (Unpublished M.Sc. thesis). Victoria University of Wellington.

Pickrill, R. A., \& Irwin, J. (1978). Shallow-water sand bars on the Ruamahanga River delta Lake Wairarapa. New Zealand Journal of Marine and Freshwater Research, 12(2), 109-19.

Pillans, B., Kohn, B. P., Berger, G., Froggatt, P., Duller, G., Alloway, B., \& Hesse, P. (1996). Multi-method dating comparison for mid-Pleistocene Rangitawa tephra, New Zealand. Quaternary Science Reviews, 15(7), $641-653$.

Pillans B, Alloway B, Naish T, Westgate J, Abbott S, Palmer A 2005. Silicic tephras in Pleistocene shallow-marine sediments of Wanganui Basin, New Zealand. Journal of the Royal Society of New Zealand 35: 43-90

Rampton, J. (1997). The Stratigraphy and Geologic History of the Late Neogene Sequence Within the Ngarara Stream-Huangarua River Region, Southeastern Wairarapa, New Zealand (Unpublished M.Sc. thesis). 
Victoria University of Wellington.

Rataul, M. (1988). Sedimentology of Hautotara and Te Muna Formations, Wairarapa, New Zealand (Unpublished M.Sc. thesis). Victoria University of Wellington.

Rodley, D. R. (1961). The Geology and Paleoecology of Nukumaruan Strata Near the Junction of Ruakokopatuna and Makara Rivers (Unpublished M.Sc. thesis). Victoria University of Wellington.

Senior, B. R. (1966). Stratigraphy and Paleoecology of an area north-east of Martinborough, Wairarapa (Unpublished M.Sc. thesis). Victoria University of Wellington.

Shane, P. A. R. (1990). Correlation of some Pliocene tuffs in Southern Wairarapa, New Zealand, and comparison with biostratigraphic and magnetostratigraphic data. New Zealand Journal of geology and geophysics, 33(2), 349-354.

Shane, P. A. R. (1991). Remobilised silicic tuffs in middle Pleistocene fluvial sediments, southern North Island, New Zealand. New Zealand journal of geology and geophysics, 34(4), 489-499.

Shane, P. A. R., \& Froggatt, P. C. (1991). Glass chemistry, paleomagnetism and correlation of middle Pleistocene tuffs in southern North Island, New Zealand and Western Pacific. New Zealand journal of geology and geophysics, 34(170-W), 203-211.

Shane, P., Froggatt, P., Black, T., \& Westgate, J. (1995). Chronology of Pliocene and Quaternary bioevents and climatic events from fission-track ages on tephra beds, Wairarapa, New Zealand. Earth and Planetary Science Letters, 130(1-4), 141-154. 
Shane, P. A., Black, T. M., Alloway, B. V., \& Westgate, J. A. (1996). Early to middle Pleistocene tephrochronology of North Island, New Zealand: Implications for volcanism, tectonism, and paleoenvironments. Geological Society of America Bulletin, 108(8), 915.

Thomson, A. B. (1980). The Structure, Stratigraphy and Paleontology of Late Cenozoic Strata, Blue Rock Stream, Wairarapa (Unpublished B.Sc. Honours thesis). Victoria University of Wellington.

Thomson, J. A. (1919). Geological and Palaeontological notes on the Palliser Bay District. New Zealand Journal of Science \& Technology, 2, 6-7.

Vella, P. (1949). The geology of an area southeast of Martinborough (Unpublished M.Sc. thesis). Victoria University of Wellington.

Vella, P. (1963a). Plio-Pleistocene cyclothems, Wairarapa, New Zealand. In Transactions of The Royal Society of New Zealand (Vol. 2, pp. 15-50).

Vella, P. (1963b). Upper Pleistocene succession in the inland part of Wairarapa Valley, New Zealand. Transactions of the Royal Society of New Zealand, Geology 2 (4), 63-78.

Vella, P., \& Briggs, W. M. (1971). Lithostratigraphic names, upper Miocene to lower Pleistocene, northern Aorangi range, Wairarapa. New Zealand Journal of geology and geophysics, 14, 253-274.

Waghorn, R. J. (1927). The geology of the Ruakokopatuna Valley, southern Wairarapa. In Transactions of the New Zealand Institute (Vol. 57, pp. 226-234).

Walker, R. G., \& James, N. P. (1992). Facies Models: Response to Sea Level Change (2nd ed.). Geological Association of Canada. 
Wallace, L.M., Beavan, J., McCaffrey, R., and Darby, D., 2004, Subduction zone coupling and tectonic block rotations in the North Island, New Zealand. Journal of Geophysical Research, v. 109, p. 21.

Woolfe, K. J. (1993). Lakes Onoke and Wairarapa as modern analogues for the Hautotara and Te Muna Formations (Mid-Pleistocene), southern Wairarapa, New Zealand. Sedimentary Geology, 84(1-4), 123-137.

Woolfe, K. J. (1995). Textural entropy groupings from a modern lake-lagoon system and its ancient analogue. New Zealand Journal of Geology and Geophysics, 38(2), 259-262. 
Appendices 
Appendix One

Geological Map 
GEOLOGICAL MAP OF THE HAUTOTARA AND TE MUNA FORMATIONS SOUTHEAST OF MARTINBOROUGH, WAIRARAPA, NEW ZEALAND

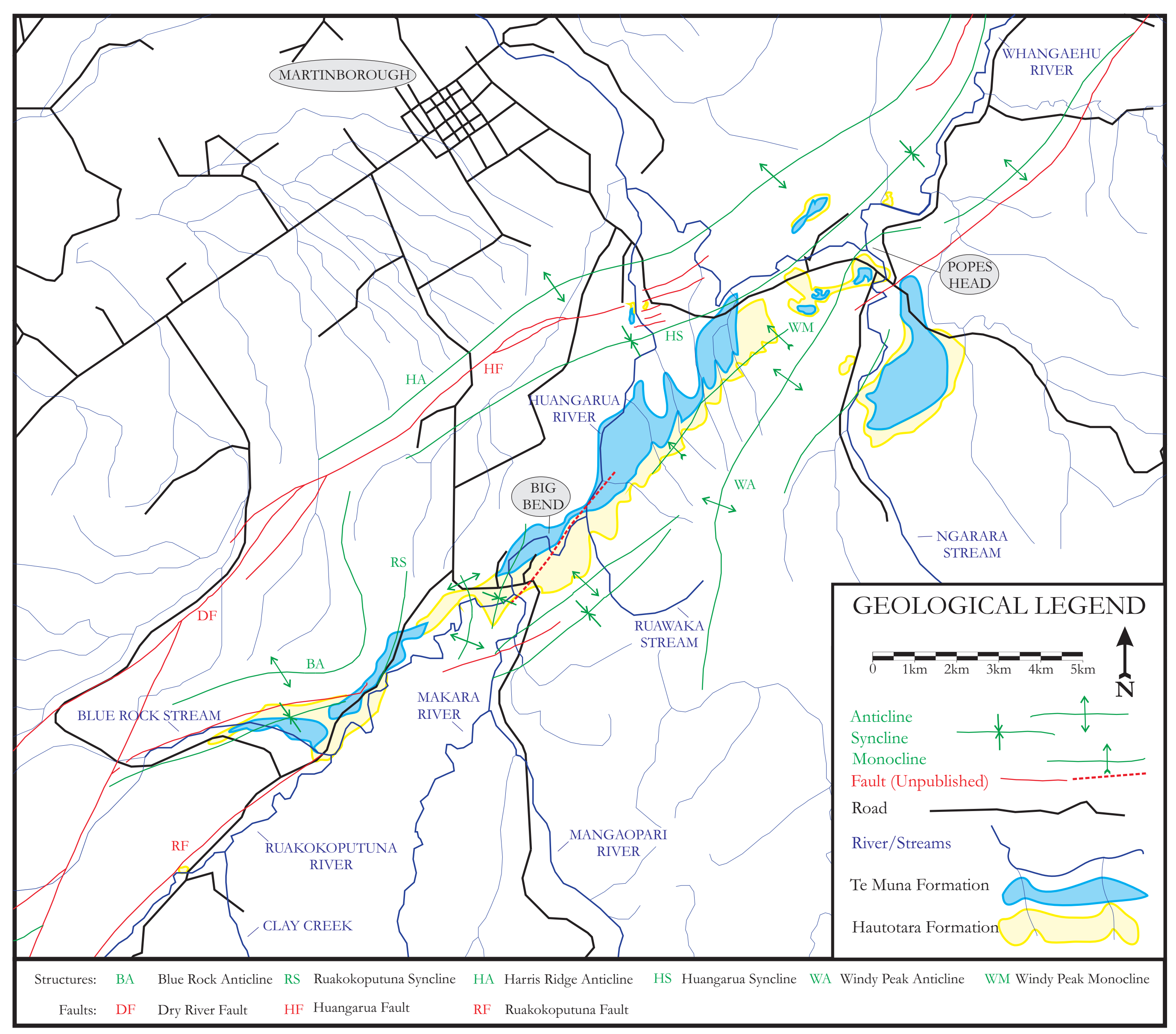


Appendix Two

Stratigraphic Columns 


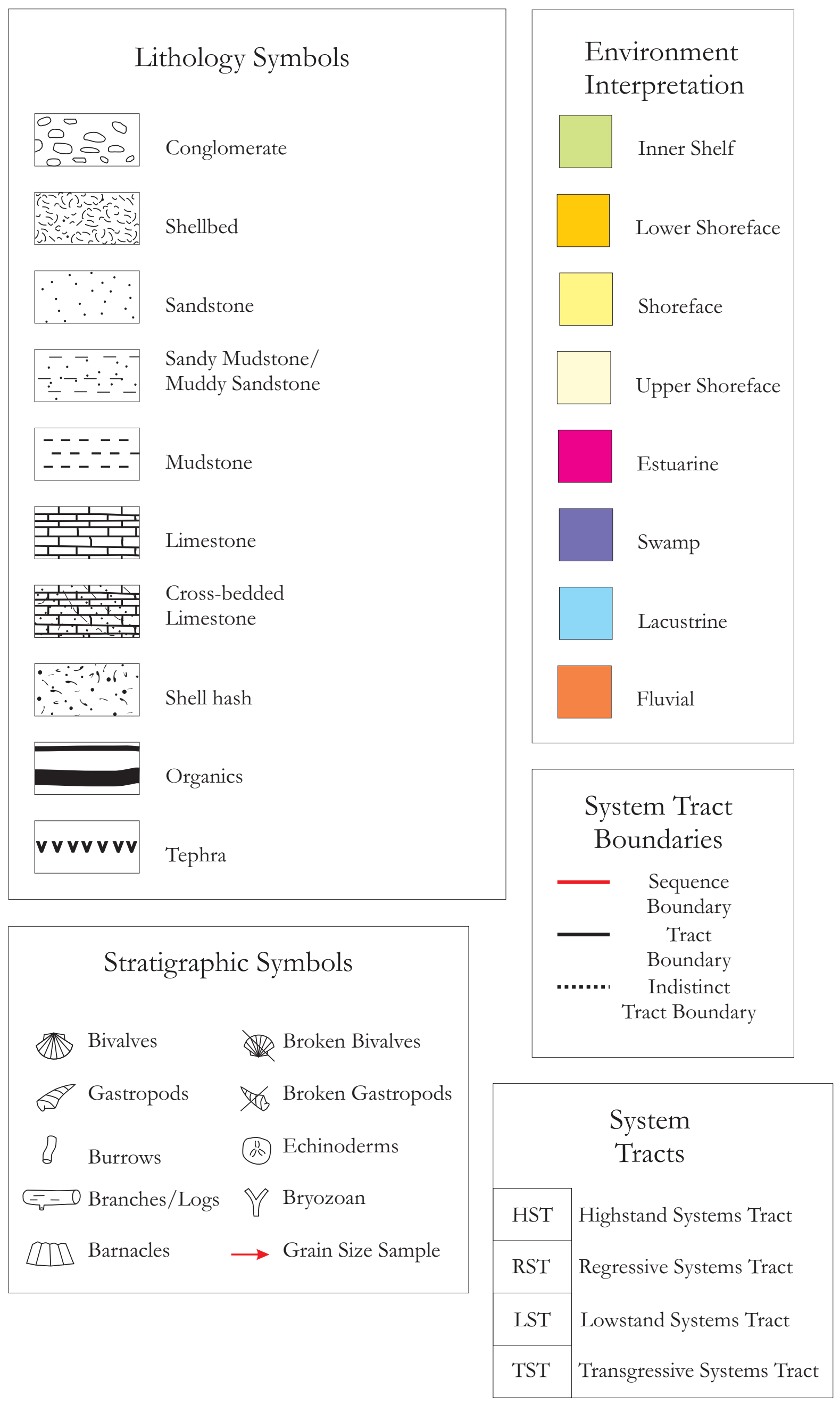




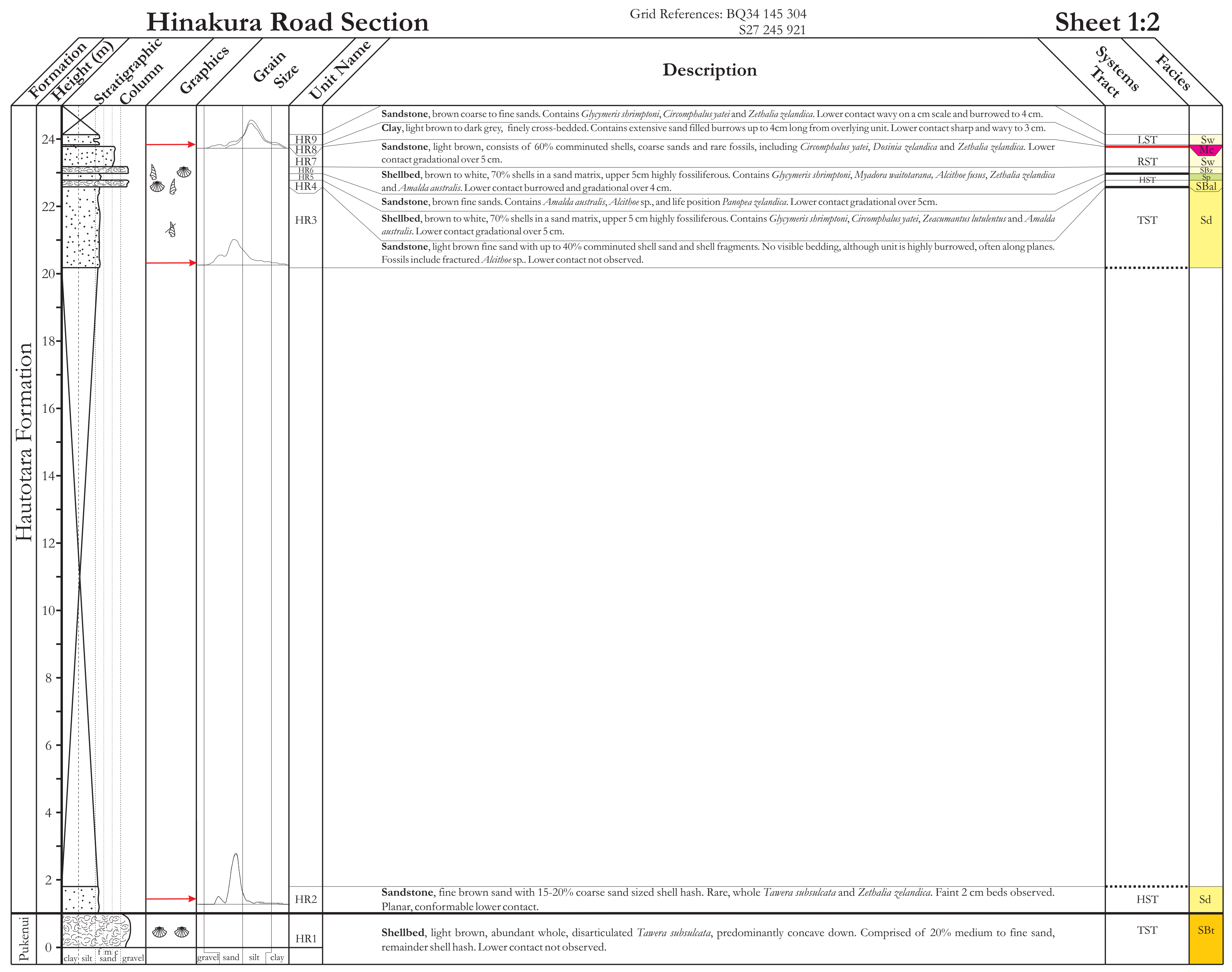




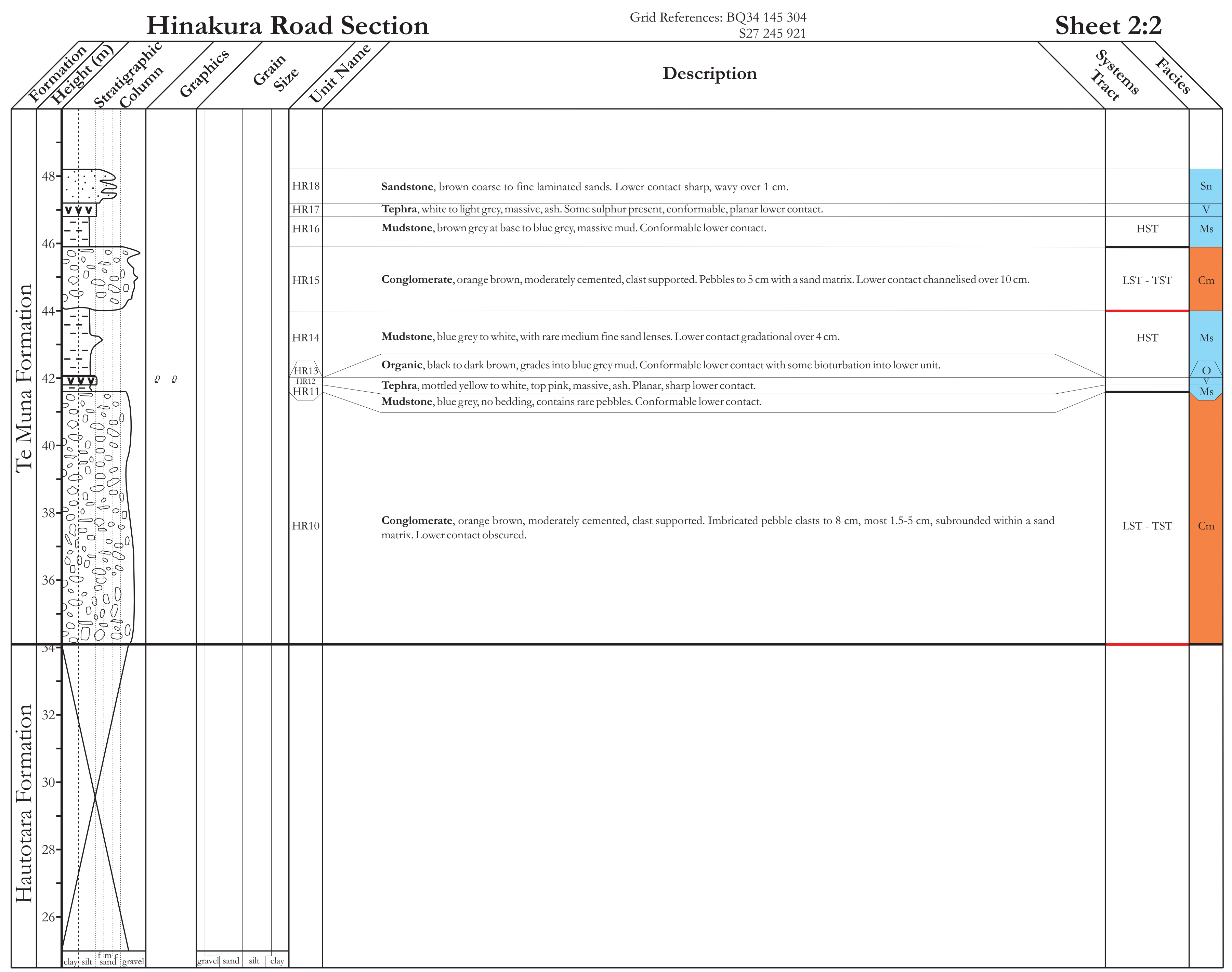




\section{Huangarua West Section}

\section{Sheet 1:2}

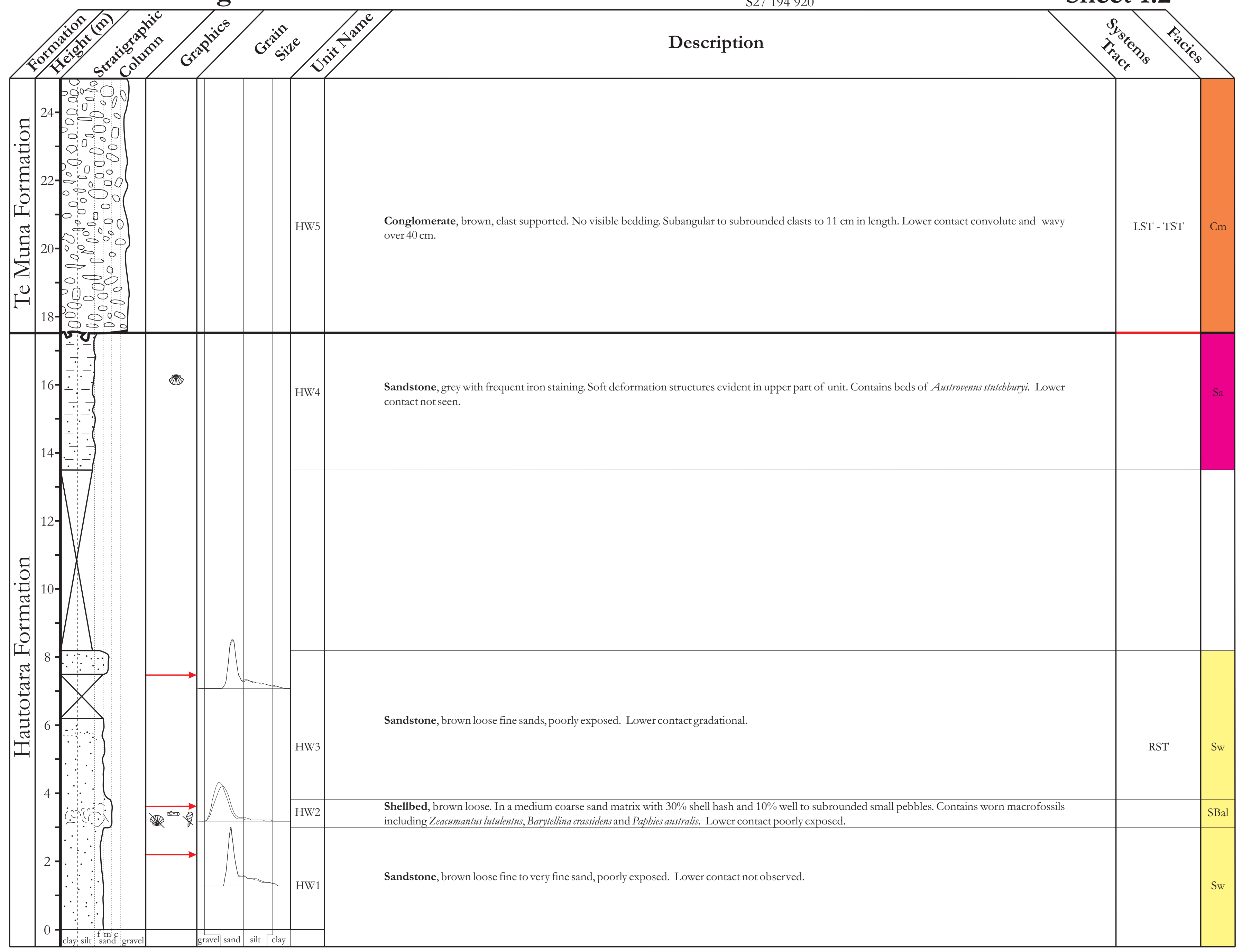




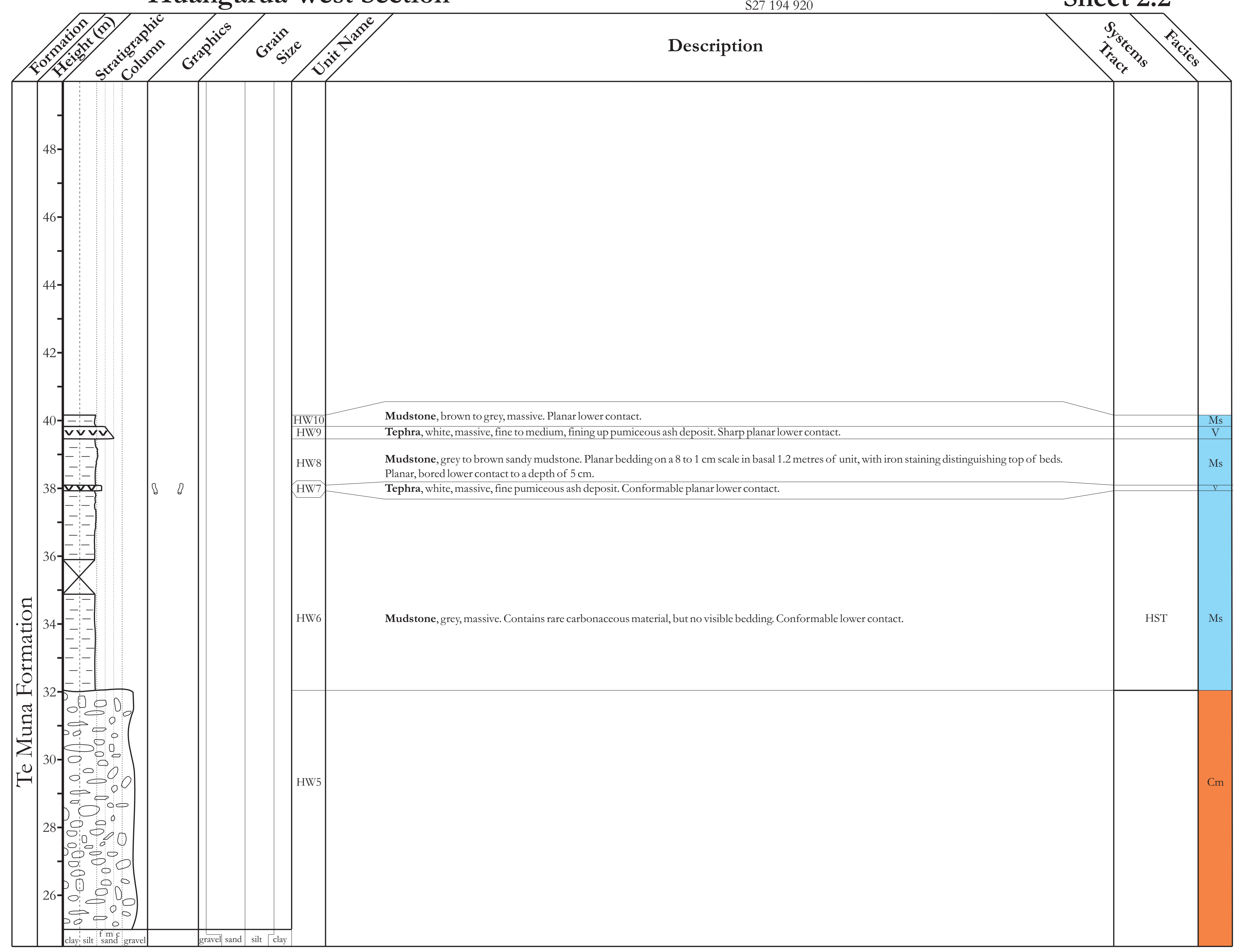




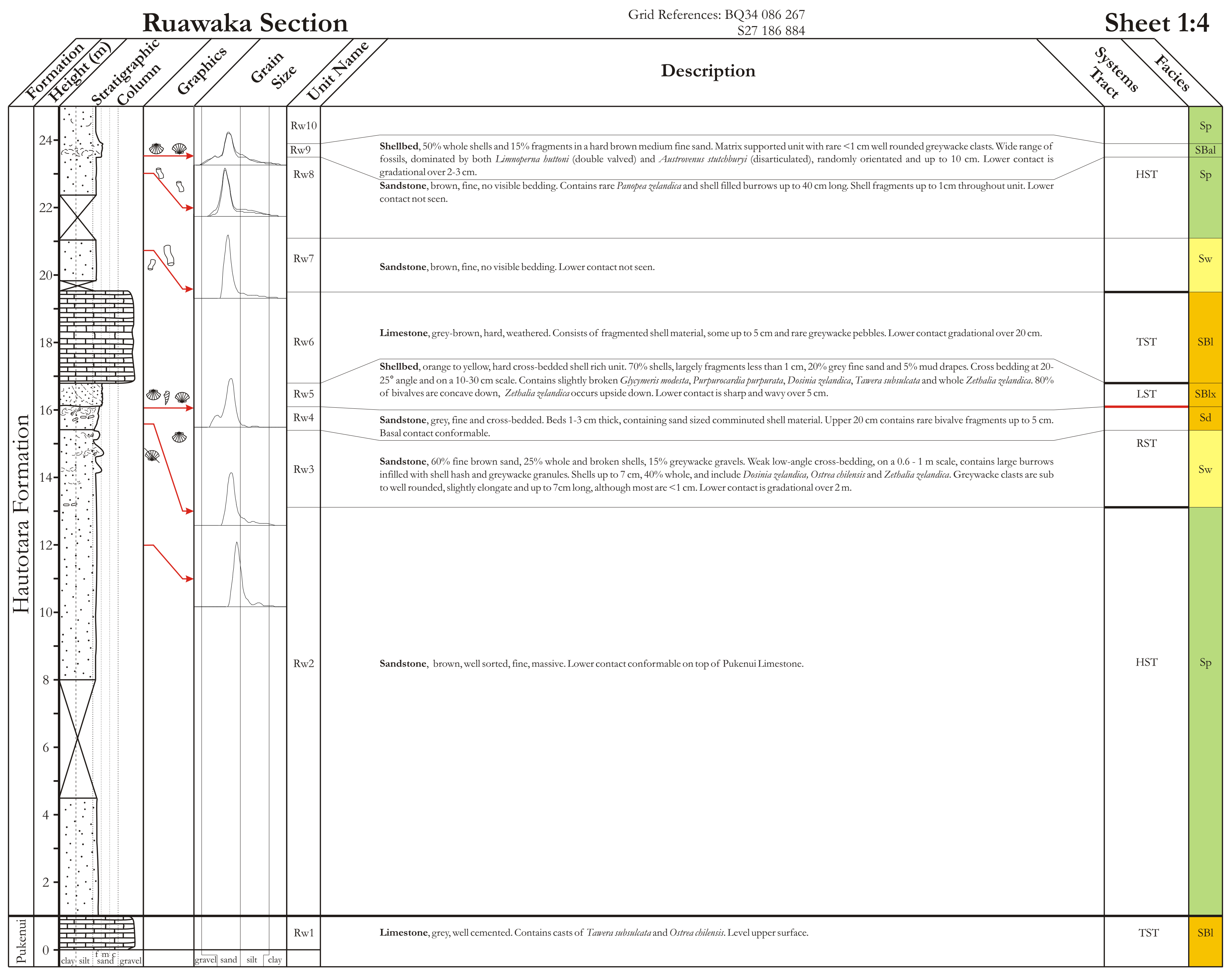




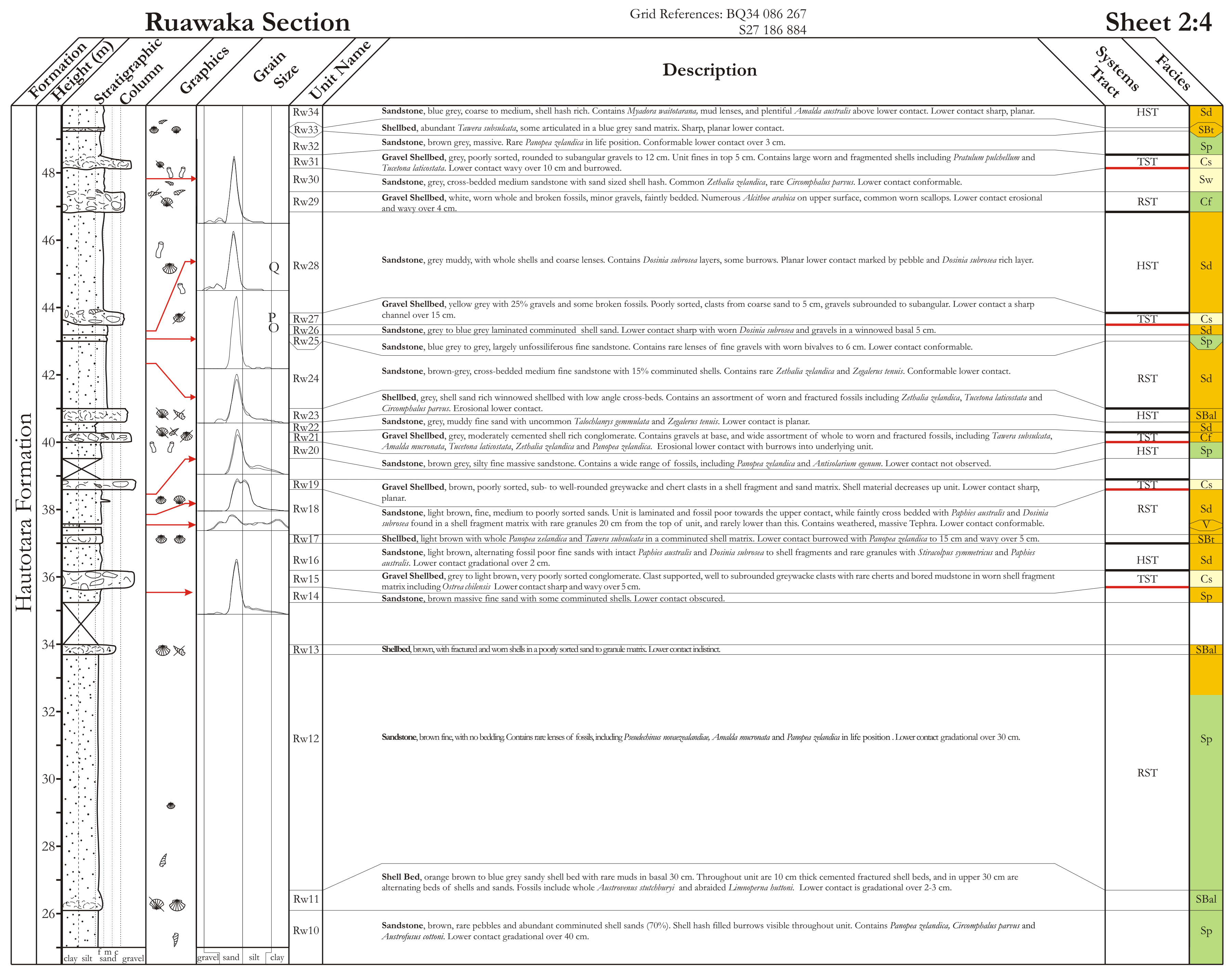




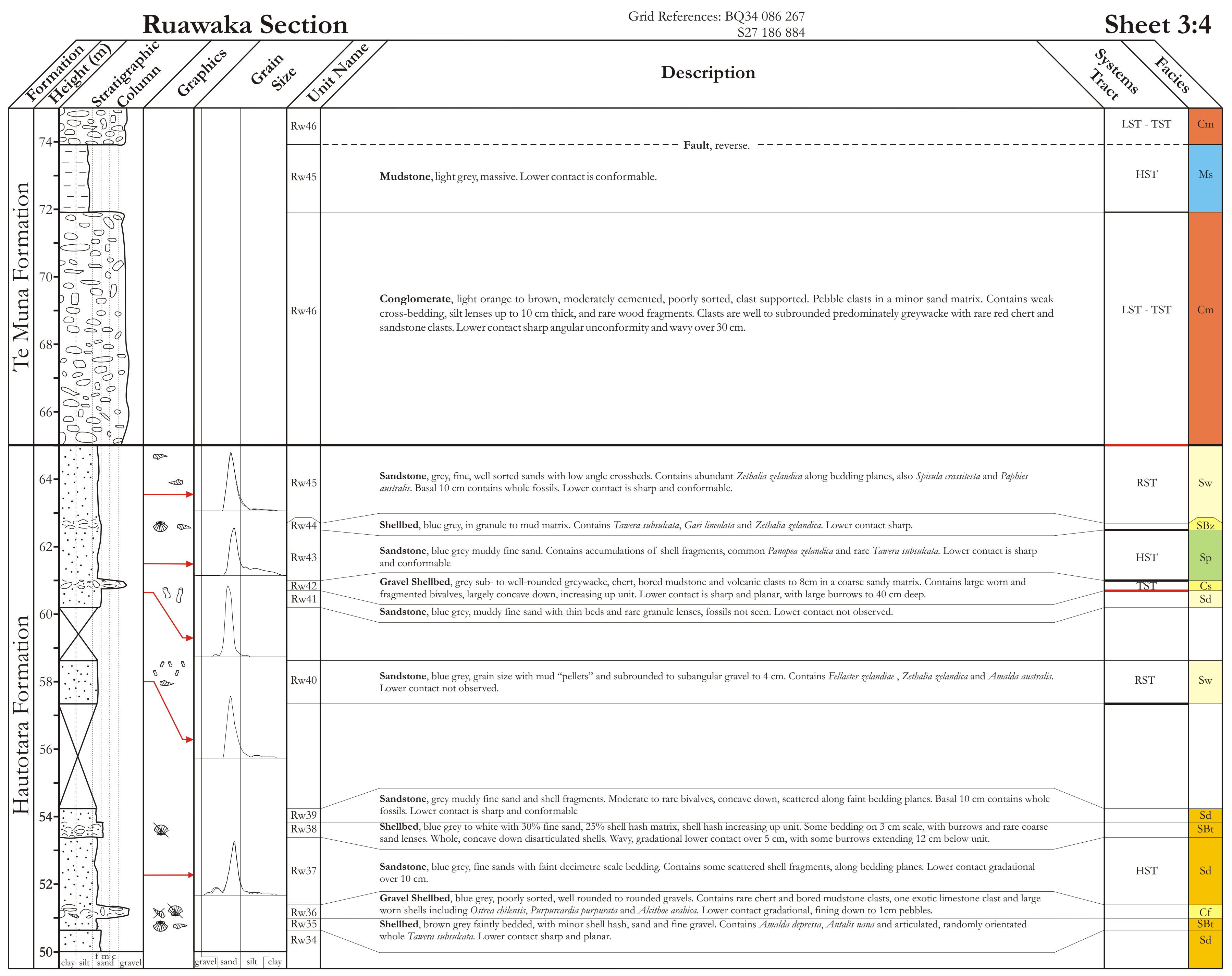




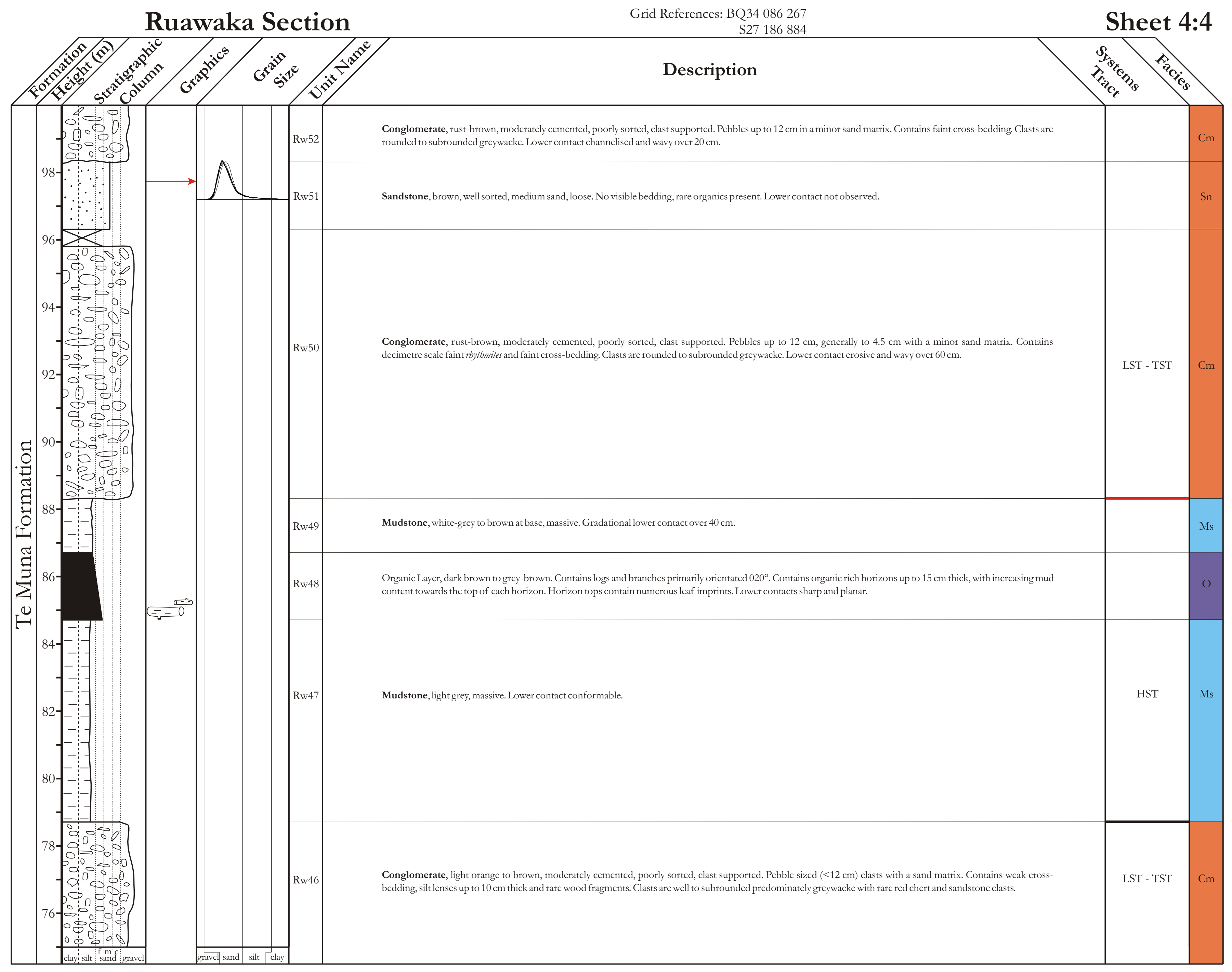




\section{Ruakokoputuna Bridge Section}

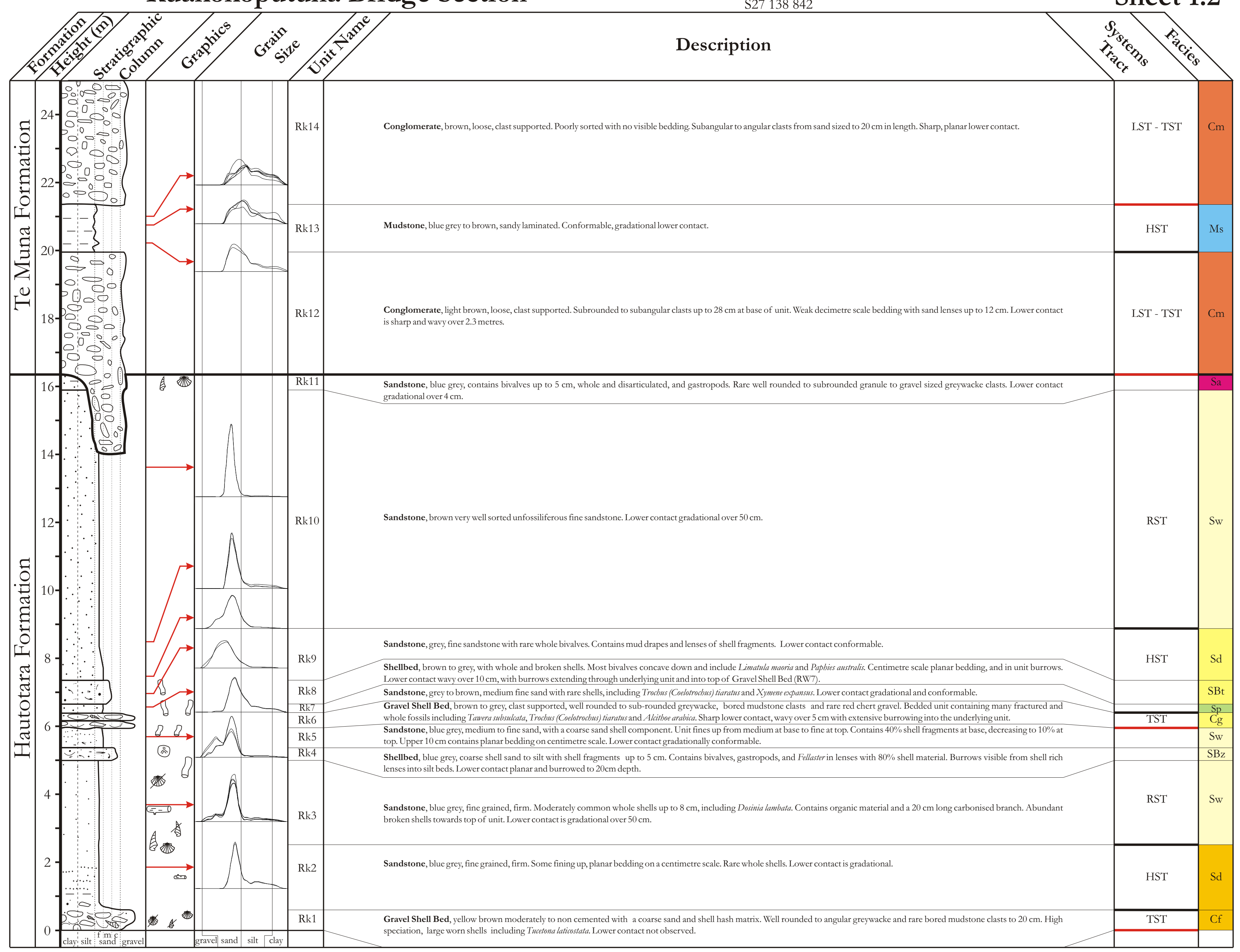




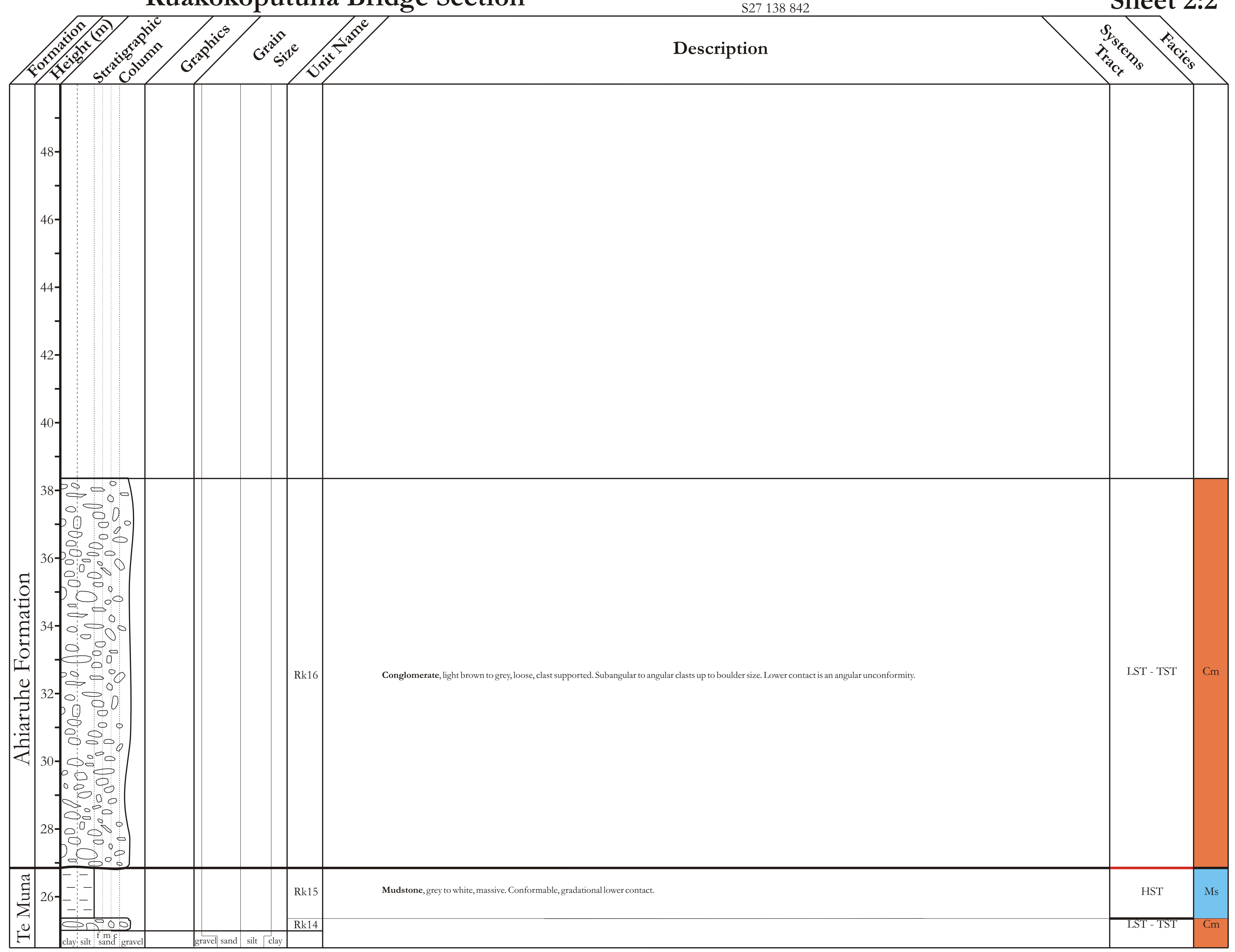



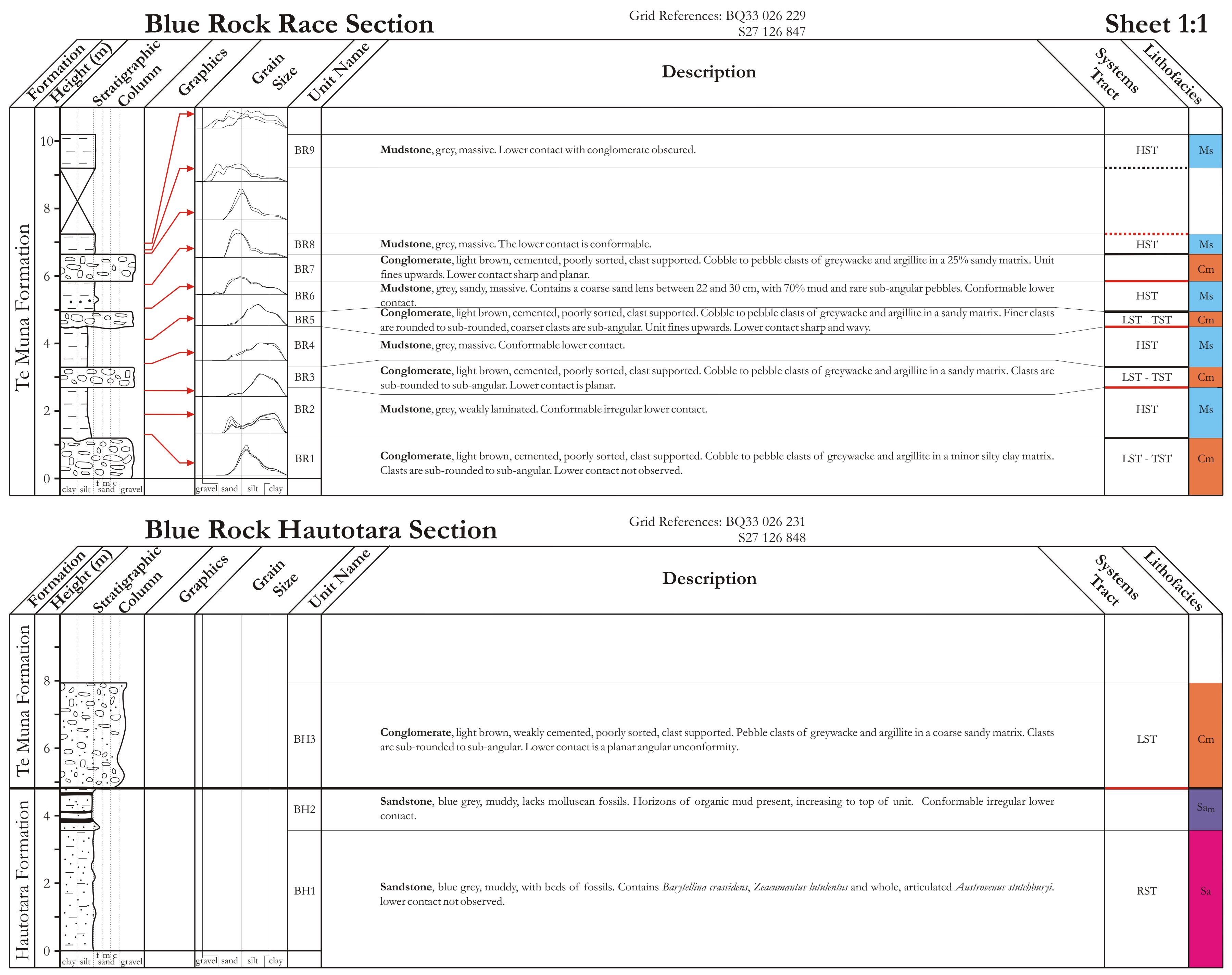


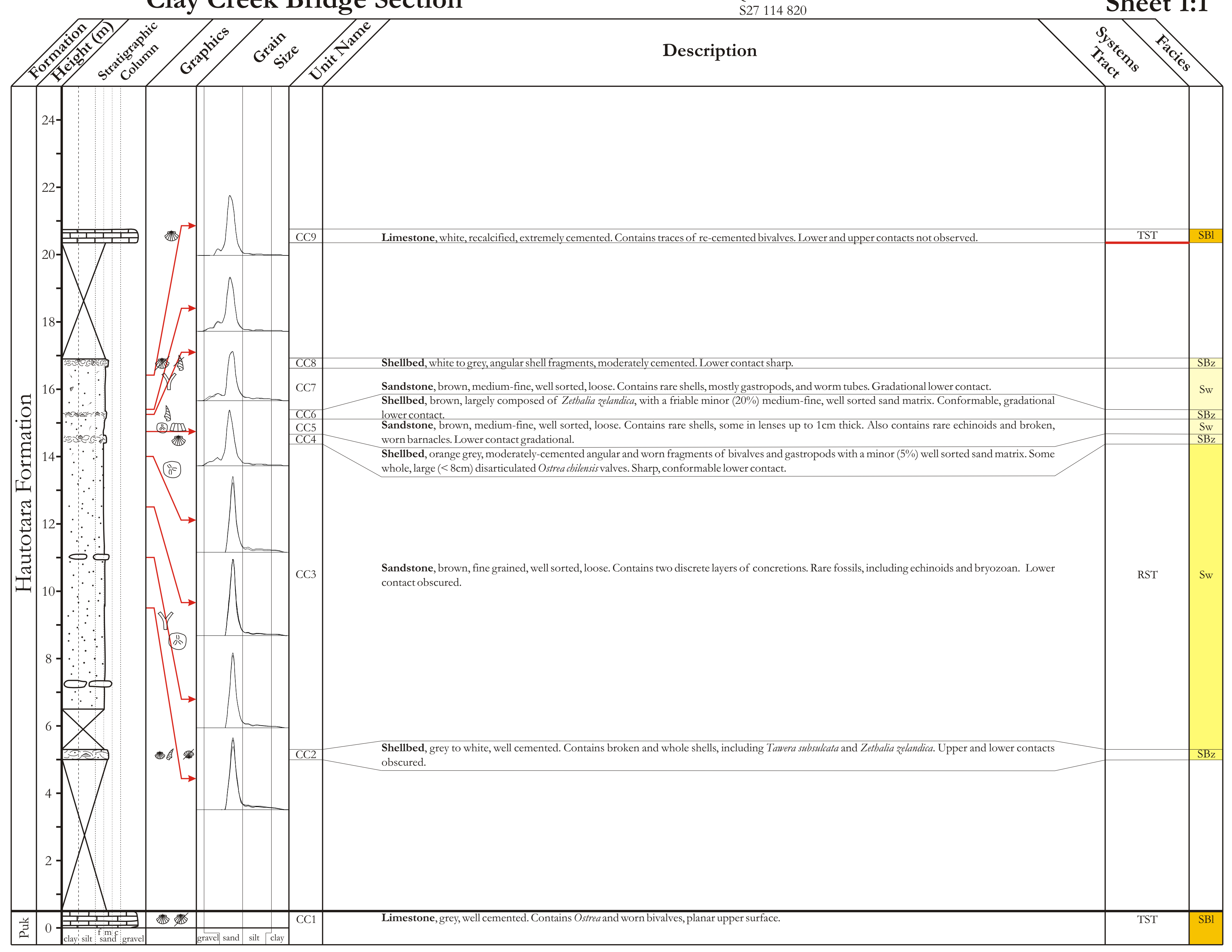


Appendix Three

Grain size 
Hinakura Road Section

Class midpoints

$\begin{array}{lllllllllllllllllllllllll}-1.75 & -1.25 & -0.75 & -0.25 & 0.25 & 0.75 & 1.25 & 1.75 & 2.25 & 2.75 & 3.25 & 3.75 & 4.25 & 4.75 & 5.25 & 5.75 & 6.25 & 6.75 & 7.25 & 7.75 & 8.25 & 8.75 & 9.25 & 9.75 & 10\end{array}$ Class limits

HR8

Mc

Frequency $\%$

Cumulative \%

$\begin{array}{lllllllllllllllllllllllll}0.00 & 0.00 & 0.00 & 0.00 & 0.00 & 0.00 & 0.00 & 0.08 & 1.34 & 2.15 & 3.01 & 5.26 & 8.83 & 15.48 & 17.01 & 14.79 & 10.26 & 6.39 & 4.54 & 3.80 & 3.33 & 2.47 & 1.11 & 0.13 & 0.00\end{array}$ Hinaku_3lb_39.\$s

$\begin{array}{lllllllllllllllllllllllll}0.00 & 0.00 & 0.00 & 0.00 & 0.00 & 0.00 & 0.00 & 0.08 & 1.42 & 3.58 & 6.59 & 11.85 & 20.68 & 36.16 & 53.17 & 67.96 & 78.22 & 84.62 & 89.16 & 92.97 & 96.30 & 98.76 & 99.87 & 100 & 100\end{array}$

Mean: Median: Mode: S.D.

$\begin{array}{llll}4.91 & 5.4 & 5.12 & 1.43\end{array}$

$\%>\quad 5 \quad 16 \quad 25 \quad 75 \quad 84 \quad 95$

$\begin{array}{llllll}3.28 & 4.28 & 4.66 & 6.31 & 6.94 & 8.3\end{array}$

$\%$ Gravel Sand Silt Clay

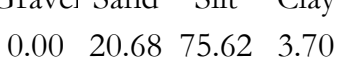

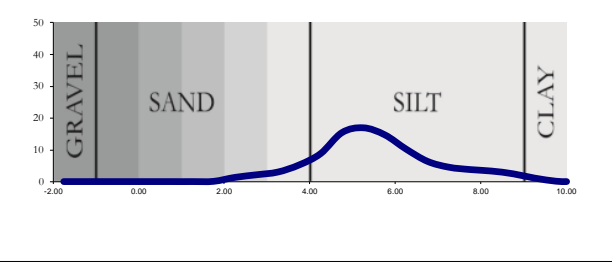

HR8

Mc

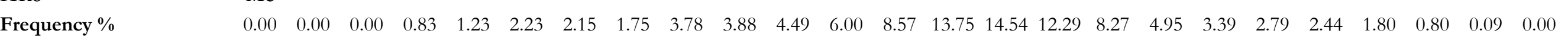

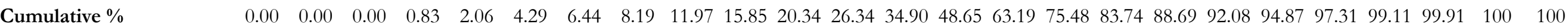

Hinaku_3lb_38.\$1s

$\begin{array}{lccc}\text { Mean: } & \text { Median: } & \text { Mode: } & \text { S.D. } \\ 3.51 & 5.05 & 4.99 & 1.92\end{array}$

$\begin{array}{lllllll}\% & 5 & 16 & 25 & 75 & 84 & 95\end{array}$

$\begin{array}{lllllll}1.13 & 3.02 & 3.9 & 5.98 & 6.52 & 8.03\end{array}$

$\%$ Gravel Sand Silt Clay $\begin{array}{llll}0.00 & 34.90 & 62.41 & 2.69\end{array}$

\begin{tabular}{l}
\hline HR3 \\
Frequency \% \\
Cumulative \%
\end{tabular}

$\begin{array}{llllllllllllllllllllllllll}0.00 & 0.00 & 0.00 & 0.43 & 1.65 & 5.51 & 6.00 & 5.41 & 10.52 & 15.43 & 14.72 & 10.82 & 8.08 & 5.28 & 2.99 & 2.89 & 2.60 & 2.01 & 1.67 & 1.48 & 1.26 & 0.87 & 0.34 & 0.02 & 0.00\end{array}$

$\begin{array}{lllllllllllllllllllllllll} & \end{array}$

Hinaku_2a_37.\$ls Mean: Median: Mode: S.D.

$\begin{array}{llcc}2.56 & 3.16 & 2.97 & 1.78\end{array}$

$\%>\quad 5 \quad 16 \quad 25 \quad 75 \quad 84 \quad 95$

$\%$ Gravel Sand Silt Clay

$\begin{array}{lllllllllll}0.81 & 1.76 & 2.32 & 4.26 & 5.02 & 7.19 & 0.00 & 78.58 & 20.19 & 1.23\end{array}$

HR2

Frequency \%

Cumulative \%

Hinaku_1b_36.\$1s
Sd

$\begin{array}{lllllllllllllllllllllllll}0.00 & 0.00 & 0.00 & 0.00 & 0.01 & 4.69 & 2.83 & 1.24 & 13.22 & 26.78 & 28.54 & 11.31 & 3.31 & 2.06 & 0.83 & 1.19 & 0.99 & 0.73 & 0.69 & 0.64 & 0.57 & 0.33 & 0.03 & 0.00 & 0.00\end{array}$ $\begin{array}{lllllllllllllllllllllllllll}0.00 & 0.00 & 0.00 & 0.00 & 0.01 & 4.70 & 7.53 & 8.77 & 22.00 & 48.78 & 77.32 & 88.63 & 91.95 & 94.00 & 94.83 & 96.02 & 97.01 & 9774 & 98 & 43 & 9906 & 99.63 & 99 & 97 & 100 & 100 & 100\end{array}$ Mean: Median: Mode: S.D.

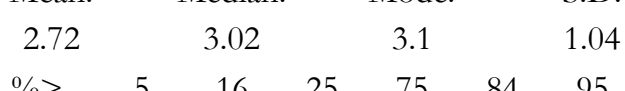

$\begin{array}{llllll}1.02 & 2.32 & 2.57 & 3.44 & 3.7 & 5.59\end{array}$

\% Gravel Sand Silt Clay $\begin{array}{llll}0.00 & 91.95 & 7.69 & 0.37\end{array}$
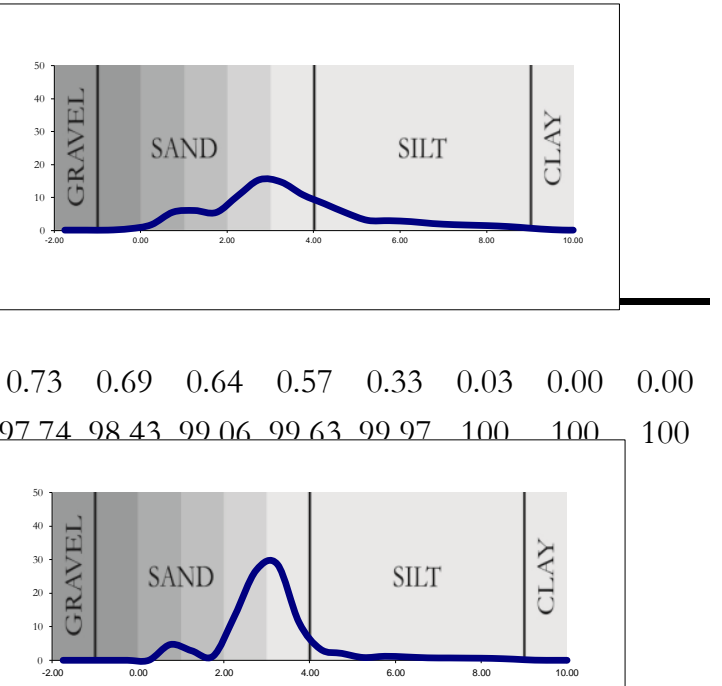
Hinakura Road Section Class midpoints Class limits

HR2

Frequency $\%$

Cumulative \%

Hinaku_1b_35.\$1s

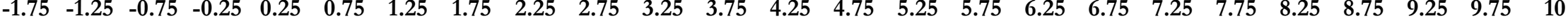

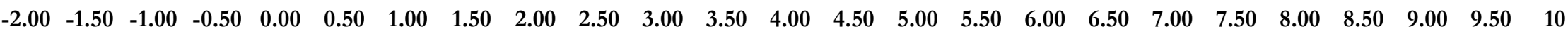

Sd

$\begin{array}{llllllllllllllllllllllllll}0.00 & 0.00 & 0.00 & 0.00 & 0.01 & 4.78 & 2.75 & 1.21 & 12.96 & 27.00 & 28.91 & 11.41 & 3.30 & 2.02 & 0.79 & 1.16 & 0.96 & 0.69 & 0.65 & 0.59 & 0.52 & 0.29 & 0.03 & 0.00 & 0.00\end{array}$ $\begin{array}{lllllllllllllllllllllllllll}0.00 & 0.00 & 0.00 & 0.00 & 0.01 & 4.79 & 7.54 & 8.75 & 21.70 & 48.70 & 77.61 & 89.02 & 92.31 & 94.33 & 95.12 & 96.27 & 97.23 & 97.92 & 98.57 & 99.16 & 99.69 & 99.97 & 100 & 100 & 100\end{array}$ Mean: Median: Mode: S.D. $\begin{array}{llll}2.72 & 3.02 & 3.1 & 1.01\end{array}$

$\begin{array}{lllllll}\%> & 5 & 16 & 25 & 75 & 84 & 95\end{array}$

$\begin{array}{llllll}1.01 & 2.33 & 2.58 & 3.44 & 3.69 & 5.44\end{array}$

$\%$ Gravel Sand Silt Clay $\begin{array}{lllll}0.00 & 92.31 & 7.37 & 0.31\end{array}$

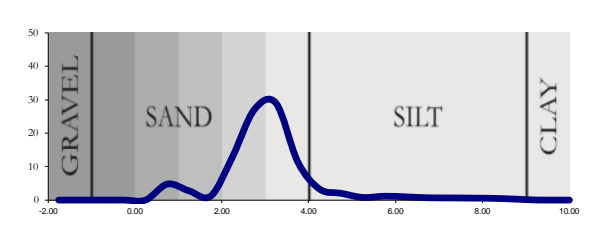


Huangarua West Section

Class midpoints

Class limits

HW 3

Frequency $\%$

Cumulative \%

HinaW_Smple1_29.\$s

$\begin{array}{lllllllllllllllllllllllll}-1.75 & -1.25 & -0.75 & -0.25 & 0.25 & 0.75 & 1.25 & 1.75 & 2.25 & 2.75 & 3.25 & 3.75 & 4.25 & 4.75 & 5.25 & 5.75 & 6.25 & 6.75 & 7.25 & 7.75 & 8.25 & 8.75 & 9.25 & 9.75 & 10\end{array}$ $\begin{array}{llllllllllllllllllllllllll}-2.00 & -1.50 & -1.00 & -0.50 & 0.00 & 0.50 & 1.00 & 1.50 & 2.00 & 2.50 & 3.00 & 3.50 & 4.00 & 4.50 & 5.00 & 5.50 & 6.00 & 6.50 & 7.00 & 7.50 & 8.00 & 8.50 & 9.00 & 9.50 & 10\end{array}$

Sw

$\begin{array}{lllllllllllllllllllllllll}0.00 & 0.00 & 0.00 & 0.00 & 0.00 & 0.00 & 0.01 & 4.21 & 25.10 & 27.81 & 10.36 & 4.80 & 5.12 & 4.60 & 3.60 & 3.32 & 2.94 & 2.38 & 1.96 & 1.62 & 1.23 & 0.73 & 0.21 & 0.00 & 0.00\end{array}$ $\begin{array}{lllllllllllllllllllllllll}0.00 & 0.00 & 0.00 & 0.00 & 0.00 & 0.00 & 0.01 & 4.21 & 29.31 & 57.13 & 67.48 & 72.28 & 77.40 & 82.00 & 85.60 & 88.92 & 91.86 & 94.24 & 96.20 & 97.82 & 99.05 & 99.78 & 100 & 100 & 100\end{array}$ Mean: Median: Mode: S.D.

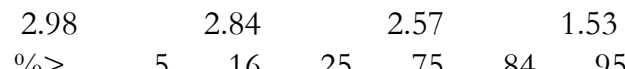

$\begin{array}{llllll}2.03 & 2.28 & 2.43 & 4.26 & 5.27 & 7.18\end{array}$

$\%$ Gravel Sand Silt Clay $0.00 \quad 77.4021 .65 \quad 0.95$

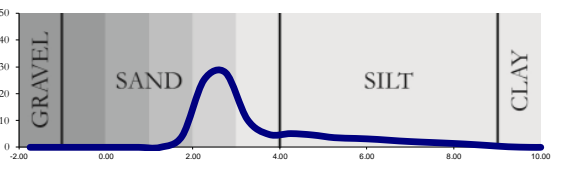

HW 3

Frequency \%

Cumulative \%

HinaW_Smple1_30.\$1

Sw

$\begin{array}{lllllllllllllllllllllllll}0.00 & 0.00 & 0.00 & 0.00 & 0.00 & 0.00 & 0.01 & 4.51 & 26.28 & 28.43 & 10.23 & 4.55 & 4.75 & 4.18 & 3.26 & 3.04 & 2.74 & 2.25 & 1.89 & 1.59 & 1.24 & 0.78 & 0.27 & 0.01 & 0.00\end{array}$

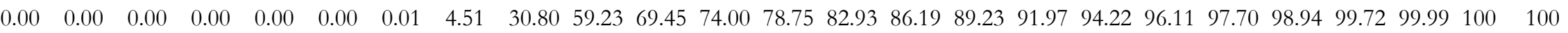
Mean: Median: Mode: S.D.

$\begin{array}{lrrrrrr}2.94 & & 2.8 & & 2.57 & & 1.51 \\ 0 \% & 5 & 16 & 25 & 75 & 84 & 95\end{array}$

$\begin{array}{llllll}2.02 & 2.27 & 2.41 & 4.1 & 5.15 & 7.2\end{array}$

$\%$ Gravel Sand Silt Clay $\begin{array}{llll}0.00 & 78.75 & 20.20 & 1.06\end{array}$

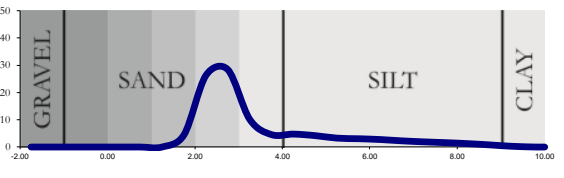

SBal

Frequency $\%$

Cum $\%$

HinaW_Smple2_31.\$1

$\begin{array}{lllllllllllllllllllllllll} & & & \end{array}$ $\begin{array}{llllllllllllllllllllllllllll}0.00 & 0.00 & 0.59 & 4.89 & 15.28 & 32.59 & 53.38 & 71.56 & 83.36 & 88.80 & 91.29 & 93.36 & 95.12 & 96.32 & 97.11 & 97.77 & 98.34 & 98.80 & 99.18 & 99.49 & 99.73 & 99.89 & 99.98 & 100 & 100\end{array}$ Mean: Median: Mode: S.D.

$\begin{array}{lrrrrrr}1.22 & & 1.42 & & 1.22 & & 1.18 \\ \%> & 5 & 16 & 25 & 75 & 84 & 95\end{array}$

$\begin{array}{llllll}0.01 & 0.52 & 0.8 & 2.12 & 2.54 & 4.46\end{array}$

$\%$ Gravel Sand Silt Clay $\begin{array}{llll}0.59 & 94.53 & 4.61 & 0.27\end{array}$

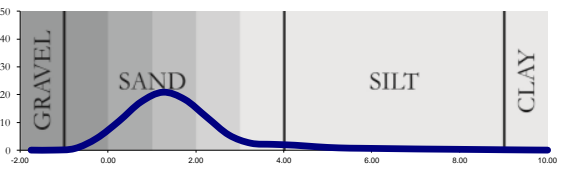

Frequency $\%$

Cumulative \%

HinaW_Smple2_32.\$1

$\begin{array}{llllllllllllllllllllllllll}0.00 & 0.00 & 0.46 & 6.55 & 16.97 & 22.55 & 21.32 & 14.58 & 7.67 & 3.10 & 1.31 & 1.20 & 0.93 & 0.79 & 0.48 & 0.49 & 0.43 & 0.31 & 0.25 & 0.22 & 0.21 & 0.15 & 0.04 & 0.00 & 0.00\end{array}$ $\begin{array}{llllllllllllllllllllllllll}0.00 & 0.00 & 0.46 & 7.01 & 23.98 & 46.53 & 67.85 & 82.44 & 90.10 & 93.21 & 94.51 & 95.71 & 96.64 & 97.43 & 97.91 & 98.39 & 98.83 & 99.13 & 99.38 & 99.60 & 99.81 & 99.96 & 100 & 100 & 100\end{array}$ Mean: Median: Mode: S.D

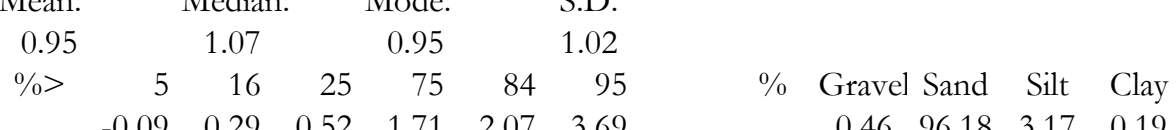

$\begin{array}{lllllll}-0.09 & 0.29 & 0.52 & 1.71 & 2.07 & 3.69\end{array}$

$\begin{array}{lllll}0.46 & 96.18 & 3.17 & 0.19\end{array}$

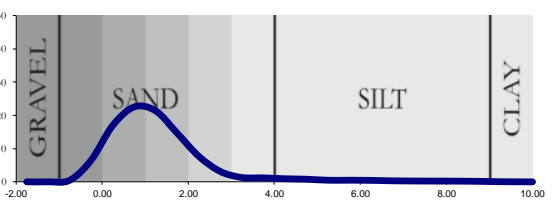


Huangarua West Section

Class midpoints Class limits

HW 1

Frequency \%

Cumulative $\%$

HinaW_Smple3_33.\$1 $\begin{array}{lllllllllllllllllllllllll}-1.75 & -1.25 & -0.75 & -0.25 & 0.25 & 0.75 & 1.25 & 1.75 & 2.25 & 2.75 & 3.25 & 3.75 & 4.25 & 4.75 & 5.25 & 5.75 & 6.25 & 6.75 & 7.25 & 7.75 & 8.25 & 8.75 & 9.25 & 9.75 & 10\end{array}$ $\begin{array}{lllllllllllllllllllllllll}-2.00 & -1.50 & -1.00 & -0.50 & 0.00 & 0.50 & 1.00 & 1.50 & 2.00 & 2.50 & 3.00 & 3.50 & 4.00 & 4.50 & 5.00 & 5.50 & 6.00 & 6.50 & 7.00 & 7.50 & 8.00 & 8.50 & 9.00 & 9.50 & 10\end{array}$ Sw

$\begin{array}{lllllllllllllllllllllllll}0.00 & 0.00 & 0.00 & 0.00 & 0.00 & 0.00 & 0.00 & 0.24 & 11.29 & 31.30 & 18.35 & 6.74 & 5.73 & 5.08 & 3.84 & 3.72 & 3.37 & 2.70 & 2.27 & 2.01 & 1.70 & 1.18 & 0.46 & 0.03 & 0.00\end{array}$ $\begin{array}{lllllllllllllllllllllllllllll}0.00 & 0.00 & 0.00 & 0.00 & 0.00 & 0.00 & 0.00 & 0.24 & 11.53 & 42.83 & 61.18 & 67.92 & 73.65 & 78.73 & 82.57 & 86.29 & 89.66 & 92.36 & 94.63 & 96.64 & 98.34 & 99.51 & 99.97 & 100 & 100\end{array}$

Mean: Median: Mode: S.D.

$\begin{array}{lrrrrr}3.29 & 3.14 & 2.84 & 1.58\end{array}$

$\begin{array}{lllllll}\%> & 5 & 16 & 25 & 75 & 84 & 95\end{array}$

$\begin{array}{llllll}2.33 & 2.58 & 2.72 & 4.62 & 5.69 & 7.59\end{array}$

$\%$ Gravel Sand Silt Clay $0.00 \quad 73.65 \quad 24.69 \quad 1.66$

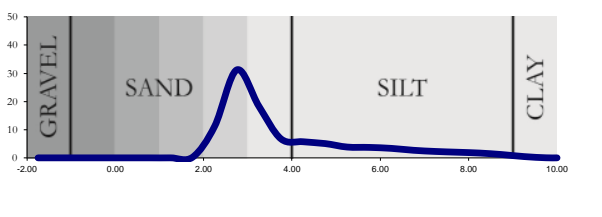

HW 1

Frequency \%

Cumulative \%

HinaW_Smple3_34.\$1$$
\text { Sw }
$$

$\begin{array}{lllllllllllllllllllllllll}0.00 & 0.00 & 0.00 & 0.00 & 0.00 & 0.00 & 0.00 & 0.29 & 11.66 & 30.53 & 17.73 & 6.53 & 5.48 & 4.98 & 3.92 & 3.96 & 3.68 & 2.97 & 2.50 & 2.19 & 1.84 & 1.26 & 0.47 & 0.02 & 0.00\end{array}$ $\begin{array}{lllllllllllllllllllllllllll}0.00 & 0.00 & 0.00 & 0.00 & 0.00 & 0.00 & 0.00 & 0.29 & 11.95 & 42.48 & 60.20 & 66.73 & 72.21 & 77.19 & 81.11 & 85.07 & 88.74 & 91.72 & 94.21 & 96.40 & 98.24 & 99.50 & 99.98 & 100 & 100\end{array}$ Mean: Median: Mode: S.D.

\begin{tabular}{|c|c|c|c|c|c|c|c|c|c|c|}
\hline \multirow{2}{*}{$\begin{array}{c}3.3 \\
\%>\end{array}$} & & 3.15 & & 2.84 & & 1.63 & \multirow{2}{*}{\multicolumn{2}{|c|}{ Gravel Sand }} & & \\
\hline & 5 & 16 & 25 & 75 & 84 & 95 & & & Silt & Clay \\
\hline & 2.32 & 257 & 2.72 & 477 & 587 & 767 & & $0.00 \quad 72.21$ & 26.03 & 1.76 \\
\hline
\end{tabular}

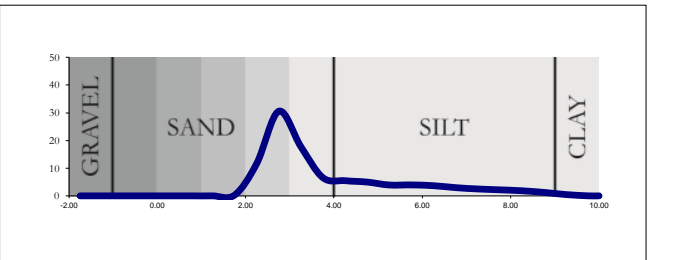


Te Muna Type Section Twin Tephra

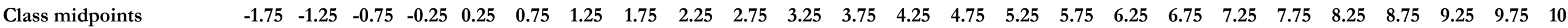
$\begin{array}{llllllllllllllllllllllllllllllllllll}\text { Class limits } & -2.00 & -1.50 & -1.00 & -0.50 & 0.00 & 0.50 & 1.00 & 1.50 & 2.00 & 2.50 & 3.00 & 3.50 & 4.00 & 4.50 & 5.00 & 5.50 & 6.00 & 6.50 & 7.00 & 7.50 & 8.00 & 8.50 & 9.00 & 9.50 & 10\end{array}$

TT S1

Frequency $\%$

Cumulative \%

TT_S1_07.\$1s $\begin{array}{lllllllllllllllllllllllll}0.00 & 0.00 & 0.00 & 0.00 & 0.00 & 0.00 & 0.00 & 0.81 & 4.44 & 6.85 & 12.62 & 18.34 & 17.93 & 11.46 & 5.41 & 4.69 & 4.12 & 3.11 & 2.75 & 2.64 & 2.47 & 1.73 & 0.61 & 0.02 & 0.00\end{array}$ $\begin{array}{lllllllllllllllllllllllllllll}0.00 & 0.00 & 0.00 & 0.00 & 0.00 & 0.00 & 0.00 & 0.81 & 5.25 & 12.10 & 24.71 & 43.06 & 60.98 & 72.45 & 77.86 & 82.55 & 86.68 & 89.79 & 92.54 & 95.17 & 97.64 & 99.37 & 99.98 & 100 & 100\end{array}$ Mean: Median: Mode: S.D.

$\begin{array}{llll}3.93 & 4.18 & 3.19 & 1.573\end{array}$

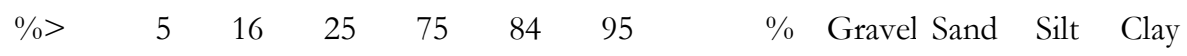

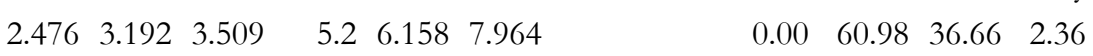

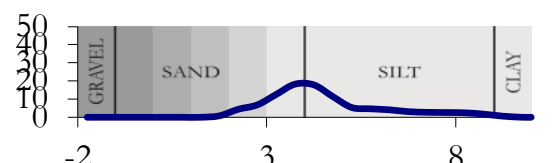

TT S1

Frequency $\%$

Cumulative \%

TT_S1_08.\$ls

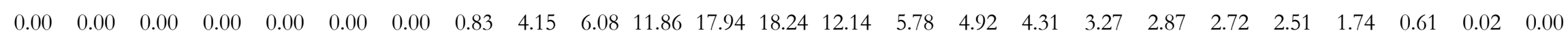

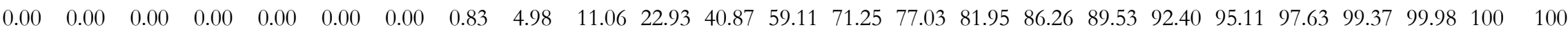

\begin{tabular}{crrrrrrrrrrrrrr} 
Mean: & & Median: & & Mode: & \multicolumn{3}{c}{ S.D. } \\
3.98 & & 4.24 & & 4.05 & & 1.572 & & & & & & \\
$\%>$ & 5 & 16 & 25 & 75 & 84 & 95 & $\%$ & Gravel Sand & Silt & Clay \\
& 2.502 & 3.249 & 3.567 & 5.294 & 6.219 & 7.977 & & 0.00 & 59.11 & 38.52 & 2.37
\end{tabular}

$\begin{array}{llllll}2.502 & 3.249 & 3.567 & 5.294 & 6.219 & 7.977\end{array}$

$\begin{array}{llll}0.00 & 59.11 & 38.52 & 2.37\end{array}$

TT S2

Frequency $\%$

Cumulative \%

TT_S2_09.\$1s

TT S2

Frequency $\%$

Cumulative \%

TT_S2_10.\$ls

$\begin{array}{lllllllllllllllllllllllllll}0 & 0 & 0 & 0 & 0 & 0 & 0 & 0.045 & 1.514 & 3.735 & 7.012 & 11.67 & 14.08 & 12.85 & 8.399 & 7.863 & 7.322 & 5.875 & 5.243 & 4.993 & 4.738 & 3.408 & 1.198 & 0.041 & 0\end{array}$ $\begin{array}{llllllllllllllllllllllllll}0.00 & 0.00 & 0.00 & 0.00 & 0.00 & 0.00 & 0.00 & 0.05 & 1.56 & 5.29 & 12.31 & 23.98 & 38.07 & 50.92 & 59.32 & 67.18 & 74.50 & 80.38 & 85.62 & 90.61 & 95.35 & 98.76 & 99.96 & 100 & 100\end{array}$

Mean: Median: Mode: S.D.

$\begin{array}{llll}4.54 & 4.96 & 4.45 & 1.75\end{array}$

$\begin{array}{lllllllllll}\%> & 5 & 16 & 25 & 75 & 84 & 95 & \% & \text { Gravel Sand } & \text { Silt } & \text { Clay }\end{array}$

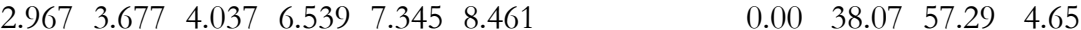
$\begin{array}{lllllllllllllllllllllllllll}0.00 & 0.00 & 0.00 & 0.00 & 0.00 & 0.00 & 0.00 & 0.20 & 2.59 & 7.03 & 15.18 & 27.95 & 42.52 & 54.76 & 62.01 & 68.68 & 74.92 & 80.04 & 84.89 & 89.83 & 94.77 & 98.49 & 99.93 & 100 & 100\end{array}$ Mean: Median: Mode: S.D.

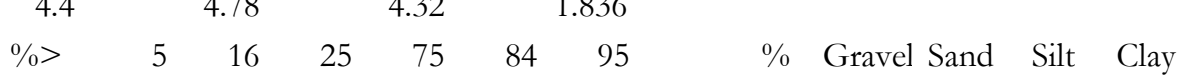
$\begin{array}{llllllllll}2.796 & 3.538 & 3.893 & 6.507 & 7.409 & 8.527 & 0.00 & 42.52 & 52.25 & 5.23\end{array}$

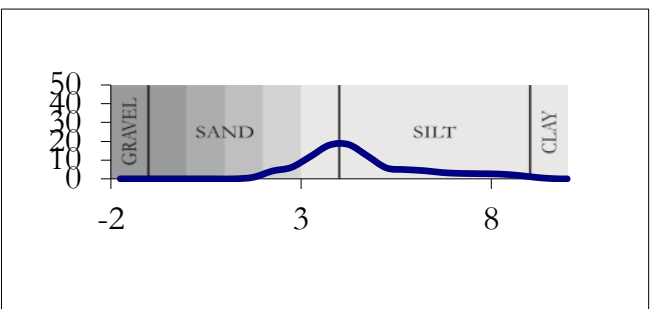
, 
Te Muna Type Section Twin Tephra

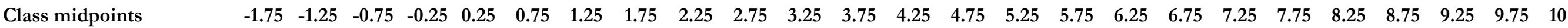

Class limits

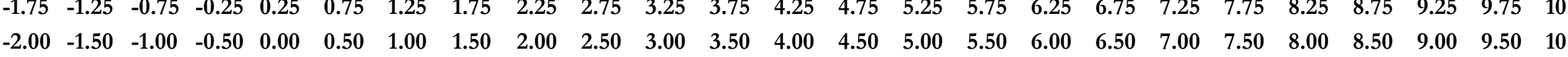

TT S3

Frequency $\%$

Cumulative \%

$\begin{array}{llllllllllllllllllllllllll}0 & 0 & 0 & 0 & 0 & 0 & 0 & 0.101 & 2.108 & 5.321 & 10.12 & 15.65 & 17.43 & 12.7 & 6.307 & 5.459 & 5.015 & 3.783 & 3.353 & 3.432 & 3.615 & 3.122 & 1.854 & 0.592 & 0.041\end{array}$

TT_S3_11.\$1s $\begin{array}{lllllllllllllllllllllllll}0.00 & 0.00 & 0.00 & 0.00 & 0.00 & 0.00 & 0.00 & 0.10 & 2.21 & 7.53 & 17.65 & 33.29 & 50.72 & 63.43 & 69.73 & 75.19 & 80.21 & 83.99 & 87.34 & 90.78 & 94.39 & 97.51 & 99.37 & 99.96 & 100\end{array}$

$\begin{array}{rcrr}\text { Mean: } & \text { Median: } & \text { Mode: } & \text { S.D. } \\ 4.24 & 4.48 & 4.18 & 1.77\end{array}$

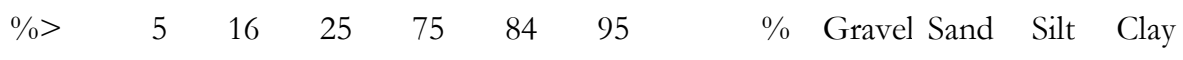

$\begin{array}{llllllllll}2.797 & 3.44 & 3.752 & 5.982 & 7.002 & 8.589 & 0.00 & 50.72 & 43.67 & 5.61\end{array}$

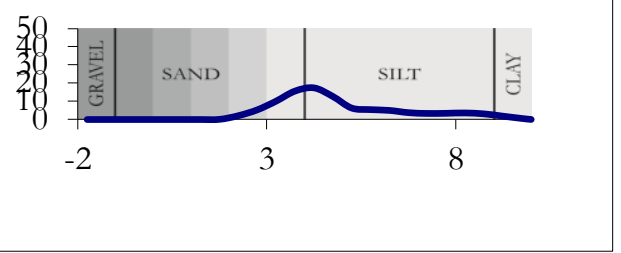

TT S3

Frequency $\%$

Cumulative \%

$\begin{array}{lllllllllllllllllllllllll}0 & 0 & 0 & 0 & 0 & 0 & 0 & 0.333 & 3.546 & 7.364 & 12.66 & 17.97 & 17.81 & 11.82 & 5.165 & 4.34 & 3.929 & 2.943 & 2.623 & 2.673 & 2.758 & 2.321 & 1.336 & 0.394 & 0.021\end{array}$ TT_S3_12.\$1s $\begin{array}{llllllllllllllllllllllllll}0.00 & 0.00 & 0.00 & 0.00 & 0.00 & 0.00 & 0.00 & 0.33 & 3.88 & 11.24 & 23.90 & 41.87 & 59.68 & 71.50 & 76.66 & 81.00 & 84.93 & 87.87 & 90.50 & 93.17 & 95.93 & 98.25 & 99.58 & 99.98 & 100\end{array}$

\begin{tabular}{crrrrrrrrrrrrr} 
Mean: & & Median: & \multicolumn{2}{c}{ Mode: } & \multicolumn{3}{c}{ S.D. } & & & & & \\
3.99 & & 4.22 & & 3.91 & & 1.66 & & & & & \\
$\%>$ & 5 & 16 & 25 & 75 & 84 & 95 & & Gravel Sand & Silt & Clay \\
& 2.591 & 3.221 & 3.534 & 5.303 & 6.366 & 8.33 & & 0.00 & 59.68 & 36.25 & 4.07
\end{tabular}

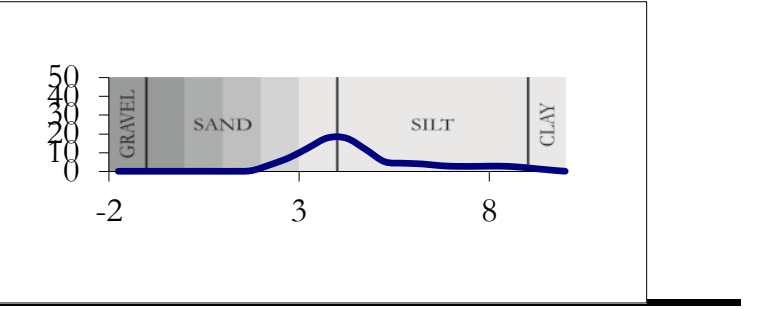

TT S4

Frequency $\%$

Cumulative \%

TT_S4sp_13.\$1

\section{TT S4}

Frequency $\%$

Cumulative \%

TT__S4sp_14.\$1s $\begin{array}{lllllllllllllllllllllllll}0.00 & 0.00 & 0.00 & 0.00 & 0.08 & 2.04 & 5.52 & 12.88 & 21.70 & 19.50 & 12.13 & 8.56 & 5.96 & 3.25 & 1.79 & 1.56 & 1.36 & 1.08 & 0.87 & 0.70 & 0.54 & 0.33 & 0.13 & 0.01 & 0.00\end{array}$ $\begin{array}{lllllllllllllllllllllllllll}0.00 & 0.00 & 0.00 & 0.00 & 0.08 & 2.12 & 7.64 & 20.52 & 42.22 & 61.72 & 73.85 & 82.42 & 88.37 & 91.62 & 93.42 & 94.98 & 96.34 & 97.42 & 98.29 & 98.99 & 99.53 & 99.87 & 99.99 & 100 & 100\end{array}$

Mean: Median: Mode: S.D.

$\begin{array}{llll}2.54 & 2.68 & 2.43 & 1.27\end{array}$

$\begin{array}{lllllllllll}\% & 5 & 16 & 25 & 75 & 84 & 95 & \% & \text { Gravel Sand } & \text { Silt } & \text { Clay }\end{array}$ $\begin{array}{llllllllll}1.306 & 1.867 & 2.116 & 3.56 & 4.112 & 6.006 & 0.00 & 88.37 & 11.16 & 0.47\end{array}$

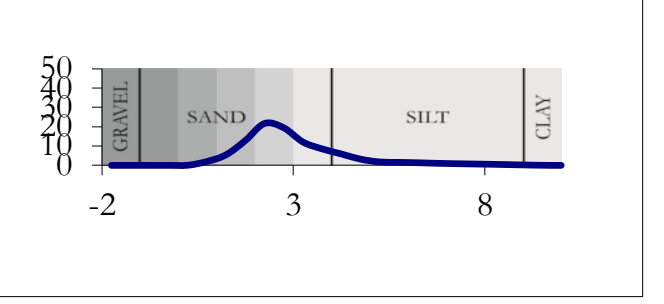

$\begin{array}{lllllllllllllllllllllllll}0.00 & 0.00 & 0.00 & 0.00 & 0.05 & 1.84 & 4.41 & 11.53 & 21.96 & 20.31 & 12.52 & 8.84 & 6.17 & 3.34 & 1.84 & 1.65 & 1.46 & 1.17 & 0.96 & 0.79 & 0.62 & 0.39 & 0.15 & 0.01 & 0.00\end{array}$ $\begin{array}{lllllllllllllllllllllllll}0.00 & 0.00 & 0.00 & 0.00 & 0.05 & 1.89 & 6.30 & 17.83 & 39.79 & 60.10 & 72.62 & 81.46 & 87.62 & 90.96 & 92.80 & 94.45 & 95.91 & 97.08 & 98.04 & 98.83 & 99.45 & 99.84 & 99.99 & 100 & 100\end{array}$

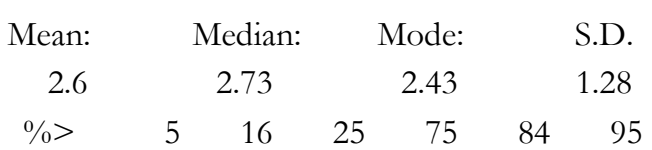

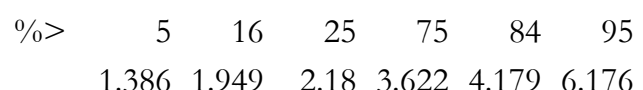

$\% \quad$ Gravel Sand Silt Clay $\begin{array}{llll}0.00 & 87.62 & 11.83 \quad 0.55\end{array}$

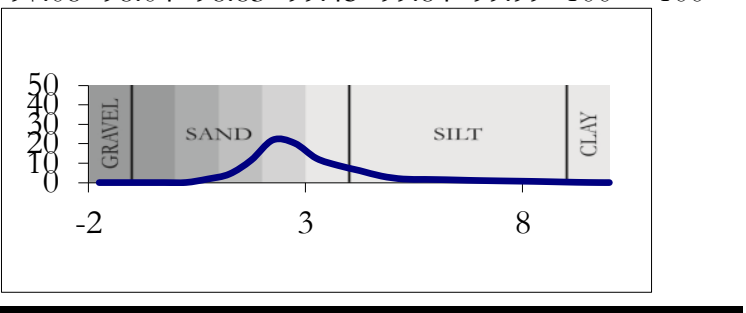


Te Muna Type Section Twin Tephra

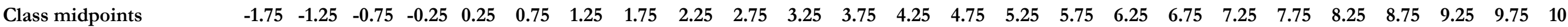

Class limits

TT S4

Frequency $\%$

Cumulative $\%$

TT__S4pp_15.\$1s

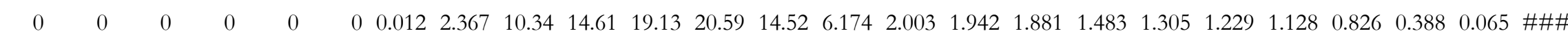
$\begin{array}{llllllllllllllllllllllllll}0.00 & 0.00 & 0.00 & 0.00 & 0.00 & 0.00 & 0.01 & 2.38 & 12.72 & 27.33 & 46.46 & 67.05 & 81.58 & 87.75 & 89.75 & 91.69 & 93.58 & 95.06 & 96.36 & 97.59 & 98.72 & 99.55 & 99.93 & 100 & 100\end{array}$

Mean: Median: Mode: S.D.

$\begin{array}{lrrrr}3.37 & 3.58 & 3.64 & 1.23\end{array}$

$\begin{array}{lllll}84 & 95 & \text { Gravel Sand } & \text { Silt } & \text { Clay }\end{array}$

$\begin{array}{llllllllll}2.163 & 2.622 & 2.928 & 4.237 & 4.635 & 6.979 & 0.00 & 81.58 & 17.14 & 1.28\end{array}$

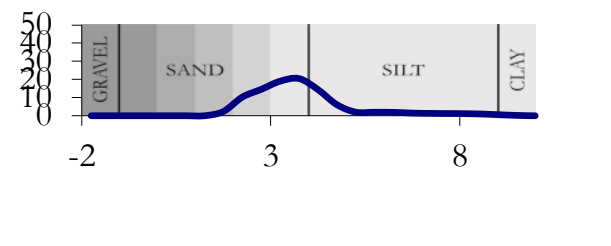

\section{TT S4}

Frequency $\%$

Cumulative \%

TT_S4pp_16.\$1s

$\begin{array}{llllllllllllllllllllllllll}0.003 & 0 & 0 & 0 & 0 & 0 & 0 & 1.78 & 9.24 & 14.14 & 19.83 & 22.14 & 15.85 & 6.532 & 1.82 & 1.607 & 1.52 & 1.16 & 1.035 & 1.025 & 0.997 & 0.782 & 0.421 & 0.111 & 0.004\end{array}$

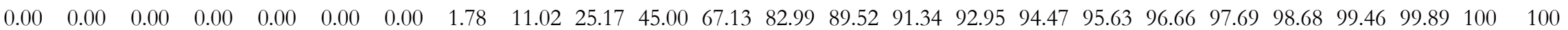

Mean: Median: Mode: S.D.

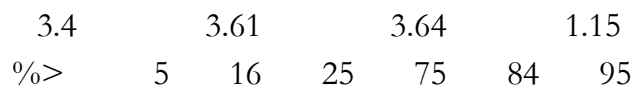

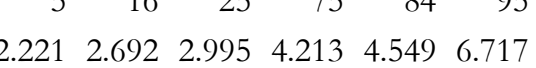

\% Gravel Sand Silt Clay

$\begin{array}{llll}0.00 & 82.98 & 15.69 & 1.32\end{array}$

TT S5

Frequency $\%$

Cumulative \%

TT_S5_17.\$1s

TT S5

Frequency \%

Cumulative \%

TT_S5_18.\$ls $\begin{array}{lllllllllllllllllllllllll}0.00 & 0.00 & 0.00 & 0.00 & 0.00 & 0.00 & 0.00 & 0.00 & 0.06 & 1.62 & 6.38 & 14.59 & 19.69 & 15.51 & 7.61 & 6.25 & 5.69 & 4.56 & 4.35 & 4.47 & 4.42 & 3.32 & 1.39 & 0.11 & 0.00\end{array}$ $\begin{array}{llllllllllllllllllllllllllll}0.00 & 0.00 & 0.00 & 0.00 & 0.00 & 0.00 & 0.00 & 0.00 & 0.06 & 1.68 & 8.05 & 22.64 & 42.33 & 57.84 & 65.45 & 71.70 & 77.38 & 81.94 & 86.29 & 90.76 & 95.18 & 98.50 & 99.89 & 100 & 100\end{array}$

Mean: Median: Mode: S.D.

$\begin{array}{llll}4.61 & 4.71 & 4.32 & 1.64\end{array}$

$\begin{array}{lllllll}\% & 5 & 16 & 25 & 75 & 84 & 95\end{array}$

$\begin{array}{llllll}3.328 & 3.805 & 4.062 & 6.274 & 7.24 & 8.479\end{array}$

$\% \quad$ Gravel Sand Silt Clay

$\begin{array}{llll}0.00 & 42.33 & 52.85 & 4.82\end{array}$
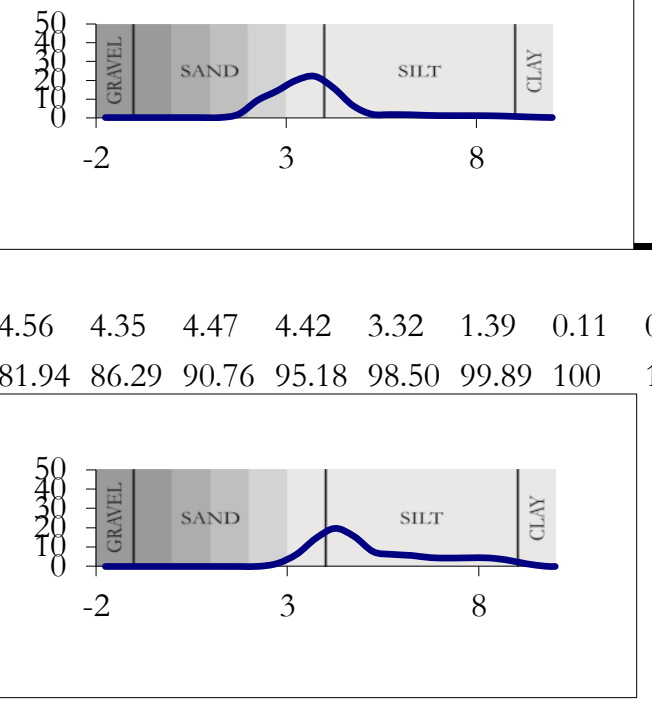

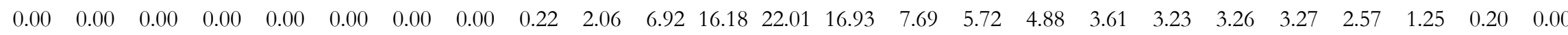
$\begin{array}{lllllllllllllllllllllllll}0.00 & 0.00 & 0.00 & 0.00 & 0.00 & 0.00 & 0.00 & 0.00 & 0.22 & 2.28 & 9.20 & 25.38 & 47.39 & 64.31 & 72.00 & 77.72 & 82.60 & 86.21 & 89.45 & 92.71 & 95.98 & 98.55 & 99.80 & 100 & 100\end{array}$

\begin{tabular}{crrrrrrrrrrr} 
Mean: & & Median: & \multicolumn{1}{c}{ Mode: } & \multicolumn{3}{c}{ S.D. } & & & & & \\
4.47 & & 4.56 & & 4.32 & & 1.50 & & & & \\
$\%>$ & 5 & 16 & 25 & 75 & 84 & 95 & $\%$ & Gravel Sand & Silt & Clay \\
& 3.269 & 3.746 & 3.991 & 5.761 & 6.68 & 8.346 & & 0.00 & 47.39 & 48.59 & 4.02
\end{tabular}

$\begin{array}{llll}0.00 & 47.39 & 48.59 & 4.02\end{array}$

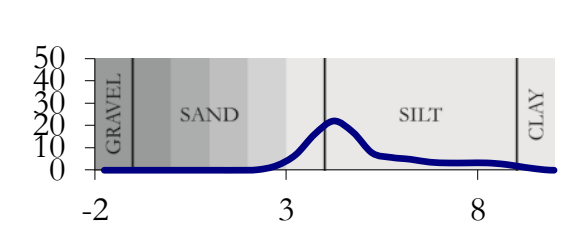


Ruawaka Section

Class midpoints

Class limits

RW51

Frequency \%

Cumulative \%

TM SAND 44

RW51

Frequency \%

Cumulative \%

Ruawak_TM SS Top_02.\$1s

RW51

Frequency \%

Cumulative \%

Ruawak_TM SS Top_03.\$1s

Frequency \%

Cumulative \%

Ruawak_TM SS Top_04.\$1

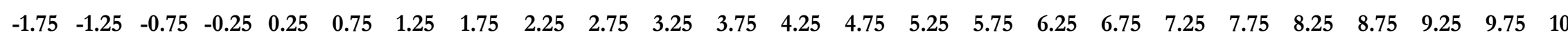

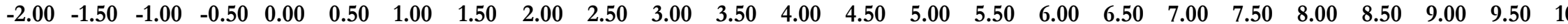

Sn

$\begin{array}{lllllllllllllllllllllllll}0.00 & 0.00 & 0.00 & 0.96 & 4.38 & 13.85 & 22.09 & 19.37 & 13.83 & 8.27 & 4.46 & 3.11 & 2.10 & 1.73 & 1.01 & 1.10 & 0.97 & 0.68 & 0.56 & 0.49 & 0.50 & 0.40 & 0.12 & 0.00 & 0.00\end{array}$

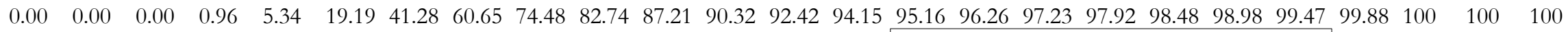

Mean: $\quad$ Median: Mode: S.D.

$\begin{array}{llll}1.6 & 1.71 & 1.22 & 1.295\end{array}$

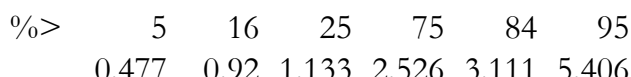

$\%$ Gravel Sand Silt Clay

$\begin{array}{llll}0.00 & 92.42 & 7.06 & 0.53\end{array}$

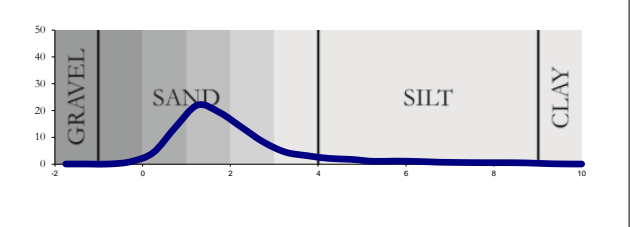

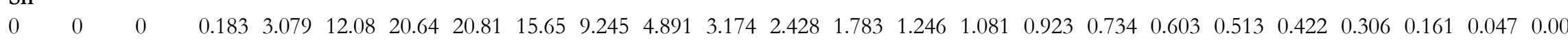
$\begin{array}{llllllllllllllllllllllllll}0.00 & 0.00 & 0.00 & 0.18 & 3.26 & 15.34 & 35.98 & 56.79 & 72.44 & 81.68 & 86.58 & 89.75 & 92.18 & 93.96 & 95.21 & 96.29 & 97.21 & 97.95 & 98.55 & 99.06 & 99.48 & 99.79 & 99.95 & 100 & 100\end{array}$

Mean: $\quad$ Median: Mode: $\quad$ S.D.

$\begin{array}{llll}1.72 & 1.83 & 1.49 & 1.271\end{array}$

$\%>\quad \begin{array}{rrrrrr}0 & 16 & 25 & 75 & 84 & 95 \\ 0.616 & 1.02 & 1.247 & 2.611 & 3.201 & 5.409\end{array}$

$\%$ Gravel Sand Silt Clay $\begin{array}{llll}0.00 & 92.18 & 7.31 & 0.52\end{array}$

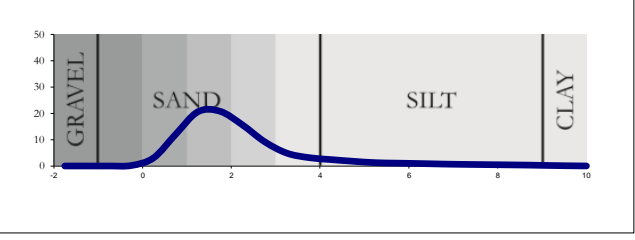

Sn

$\begin{array}{lllllllllllllllllllllllllll}0 & 0 & 0 & 0.017 & 2.657 & 14.07 & 22.25 & 20.05 & 15.75 & 9.52 & 4.68 & 3.098 & 1.89 & 1.475 & 0.795 & 0.856 & 0.746 & 0.52 & 0.436 & 0.394 & 0.394 & 0.307 & 0.087 & \# \# \# \quad 0\end{array}$ $\begin{array}{lllllllllllllllllllllllll}0.00 & 0.00 & 0.00 & 0.02 & 2.67 & 16.74 & 39.00 & 59.05 & 74.80 & 84.32 & 89.00 & 92.10 & 93.99 & 95.46 & 96.26 & 97.12 & 97.86 & 98.38 & 98.82 & 99.21 & 99.60 & 99.91 & 100 & 100 & 100\end{array}$ Mean: Median: Mode: S.D. $\begin{array}{llll}1.67 & 1.77 & 1.22 & 1.132\end{array}$ $\%>\quad \begin{array}{lllllr}5 & 16 & 25 & 75 & 84 & 95\end{array}$ $\begin{array}{llllll}0.64 & 0.981 & 1.185 & 2.508 & 2.978 & 4.819\end{array}$

$\%$ Gravel Sand Silt Clay $\begin{array}{llll}0.00 & 93.99 & 5.61 & 0.40\end{array}$

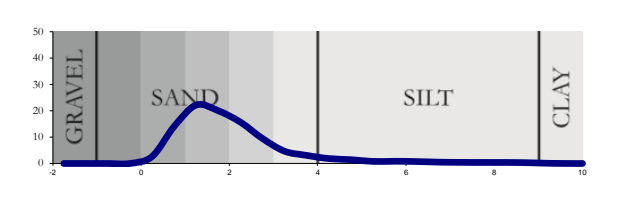

Sn

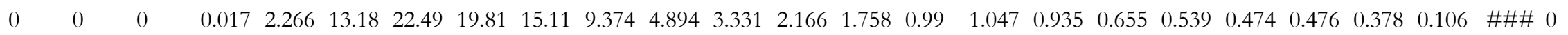
$\begin{array}{lllllllllllllllllllllllll}0.00 & 0.00 & 0.00 & 0.02 & 2.28 & 15.46 & 37.95 & 57.76 & 72.88 & 82.25 & 87.14 & 90.47 & 92.64 & 94.40 & 95.39 & 96.44 & 97.37 & 98.03 & 98.57 & 99.04 & 99.52 & 99.89 & 100 & 100 & 100\end{array}$ Mean: Median: Mode: S.D. $\begin{array}{llll}1.71 & 1.79 & 1.22 & 1.227\end{array}$ $\begin{array}{lllllll}\%> & 5 & 16 & 25 & 75 & 84 & 95\end{array}$ $0.6691 .0141 .214 \quad 2.593 \quad 3.137 \quad 5.266$

$\%$ Gravel Sand Silt Clay $\begin{array}{llll}0.00 & 92.64 & 6.87 & 0.48\end{array}$

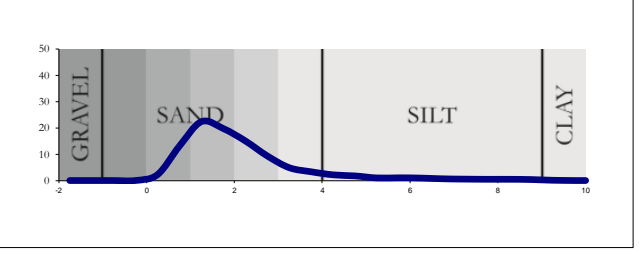


Ruawaka Section

Class midpoints

Class limits

RW51

Frequency $\%$

Cumulative \%

RW_TM49_02

\section{RW51}

Frequency \%

Cumulative \%

RW_TM49_01.\$ls

\section{RW51}

Frequency $\%$

Cumulative \%

RW49 TMsand_16.\$ls

RW51

Frequency \%

Cumulative \%

Ruawak_TMSS1_01.\$ls

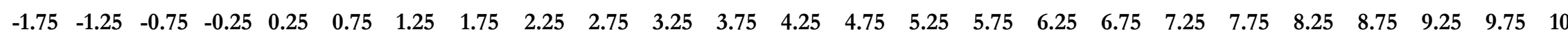
$\begin{array}{lllllllllllllllllllllllll}-2.00 & -1.50 & -1.00 & -0.50 & 0.00 & 0.50 & 1.00 & 1.50 & 2.00 & 2.50 & 3.00 & 3.50 & 4.00 & 4.50 & \mathbf{5 . 0 0} & \mathbf{5 . 5 0} & \mathbf{6 . 0 0} & \mathbf{6 . 5 0} & \mathbf{7 . 0 0} & \mathbf{7 . 5 0} & \mathbf{8 . 0 0} & \mathbf{8 . 5 0} & \mathbf{9 . 0 0} & \mathbf{9 . 5 0} & 10\end{array}$

Sn

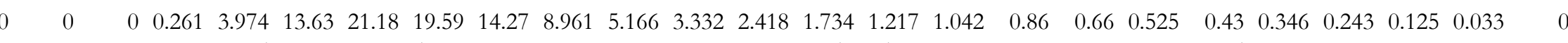
$\begin{array}{lllllllllllllllllllllllll}0 & 0 & 0 & 0.261 & 4.235 & 17.86 & 39.04 & 58.64 & 72.91 & 81.87 & 87.03 & 90.36 & 92.78 & 94.52 & 95.73 & 96.77 & 97.63 & 98.29 & 98.82 & 99.25 & 99.6 & 99.84 & 99.97 & 100 & 100\end{array}$

$\begin{array}{cccc}\text { Mean: } & \text { Median: } & \text { Mode: } & \text { S.D. } \\ 1.66 & 1.76 & 1.35 & 1.26\end{array}$

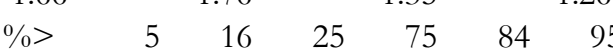

$\begin{array}{llllll}0.542 & 0.948 & 1.177 & 2.596 & 3.174 & 5.183\end{array}$

$\%$ Gravel Sand Silt Clay

$\begin{array}{llll}0.00 & 92.78 & 6.81 & 0.40\end{array}$

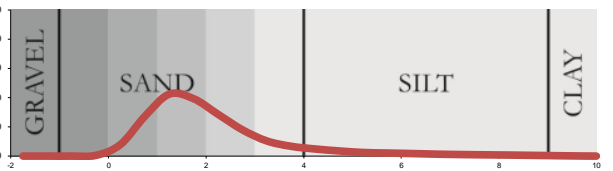

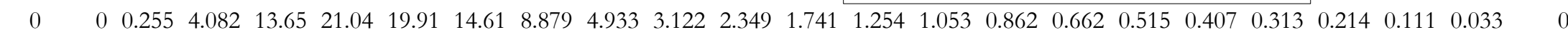

$\begin{array}{llllllllllllllllllllllllll}0 & 0 & 0 & 0.255 & 4.337 & 17.99 & 39.03 & 58.94 & 73.55 & 82.43 & 87.36 & 90.48 & 92.83 & 94.57 & 95.83 & 96.88 & 97.74 & 98.41 & 98.92 & 99.33 & 99.64 & 99.85 & 99.97 & 100 & 100\end{array}$

Mean: 2 Median: $\quad$ Mode: $\quad$ S.D.

$\begin{array}{llll}1.651 & 1.762 & 1.355 & 1.247\end{array}$

$\%>\quad \begin{array}{llllll}\% & 16 & 25 & 75 & 84 & 95\end{array}$

$\begin{array}{llllll}0.535 & 0.944 & 1.176 & 2.566 & 3.13 & 5.155\end{array}$

$\%$ Gravel Sand Silt Clay $\begin{array}{llll}0.00 & 92.83 & 6.81 & 0.36\end{array}$

Sn

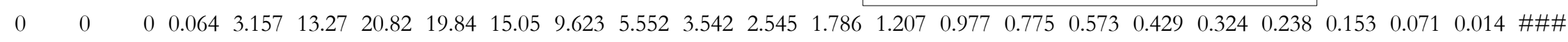
$\begin{array}{lllllllllllllllllllllllllll}0 & 0 & 0 & 0.064 & 3.22 & 16.49 & 37.31 & 57.14 & 72.19 & 81.82 & 87.37 & 90.91 & 93.45 & 95.24 & 96.45 & 97.42 & 98.2 & 98.77 & 99.2 & 99.52 & 99.76 & 99.91 & 99.99 & 100 & 100\end{array}$ Mean: Median: Mode: S.D. $\begin{array}{llll}1.699 & 1.809 & 1.355 & 1.20\end{array}$

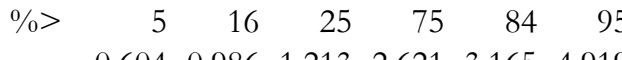

$\%$ Gravel Sand Silt Clay $\begin{array}{llll}0.00 & 93.45 & 6.31 & 0.24\end{array}$

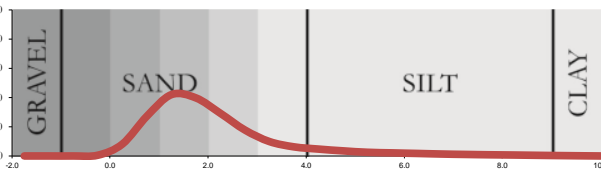

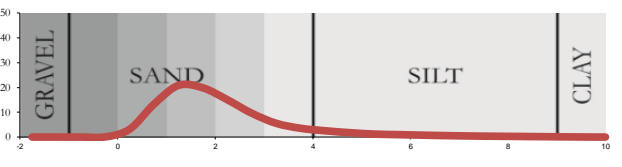

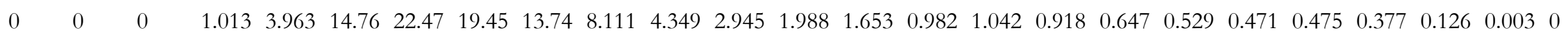

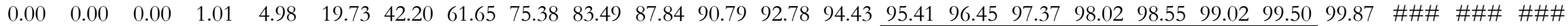

Mean: Median: Mode: S.D

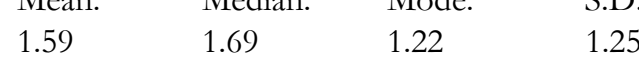

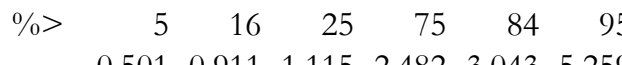

$\%$ Gravel Sand Silt Clay $\begin{array}{lllll}0.00 & 92.78 & 6.72 & 0.50\end{array}$

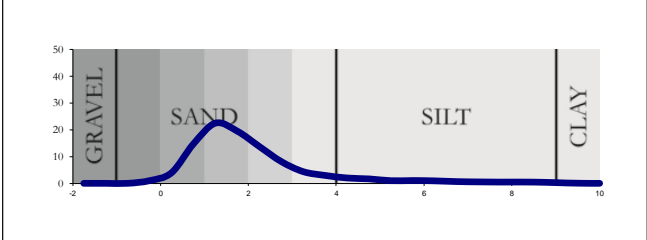


Ruawaka Section

Class midpoints

Class limits

RW51

Frequency $\%$

Cumulative \%

Ruawak_TMSS1_02.\$1s

\section{RW51}

Frequency $\%$

Cumulative \%

Ruawak_TMS_25.\$1s $\begin{array}{lllllllllllllllllllllllll}-1.75 & -1.25 & -0.75 & -0.25 & 0.25 & 0.75 & 1.25 & 1.75 & 2.25 & 2.75 & 3.25 & 3.75 & 4.25 & 4.75 & 5.25 & 5.75 & 6.25 & 6.75 & 7.25 & 7.75 & 8.25 & 8.75 & 9.25 & 9.75 & 10\end{array}$ $\begin{array}{lllllllllllllllllllllllll}-2.00 & -1.50 & -1.00 & -0.50 & 0.00 & 0.50 & 1.00 & 1.50 & 2.00 & 2.50 & 3.00 & 3.50 & 4.00 & 4.50 & 5.00 & 5.50 & 6.00 & 6.50 & 7.00 & 7.50 & 8.00 & 8.50 & 9.00 & 9.50 & 10\end{array}$

\section{$\operatorname{Sn}$}

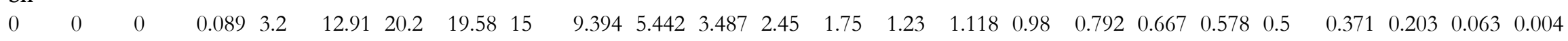

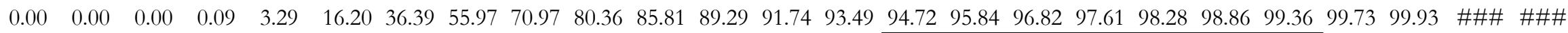
Mean: Median: Mode: S.D.

$\begin{array}{llll}1.72 & 1.84 & 1.35 & 1.34\end{array}$

$\%>\quad \begin{array}{llllll}\% & 16 & 25 & 75 & 84 & 95\end{array}$ $\begin{array}{llllll}0.603 & 0.994 & 1.226 & 2.683 & 3.303 & 5.622\end{array}$

$\%$ Gravel Sand Silt Clay $\begin{array}{llll}0.00 & 91.74 & 7.61 & 0.64\end{array}$

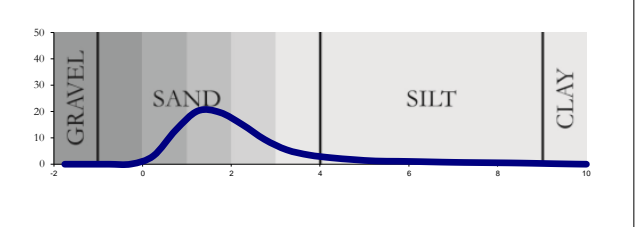

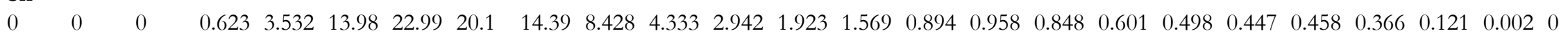
$\begin{array}{llllllllllllllllllllllllll}0.00 & 0.00 & 0.12 & 0.49 & 0.95 & 1.39 & 1.89 & 2.49 & 3.34 & 4.30 & 5.19 & 6.76 & 8.68 & 11.63 & 15.96 & 24.39 & 38.77 & 58.87 & 81.86 & 95.85 & 99.38 & \# \# \# & 100 & 100 & 100\end{array}$ Mean: Median: Mode: S.D $\begin{array}{llll}1.62 & 1.71 & 1.22 & 1.20\end{array}$

$\%$
0 $\quad \begin{array}{llllll}16 & 25 & 75 & 84 & 95\end{array}$ $\begin{array}{llllll}0.558 & 0.947 & 1.152 & 2.473 & 2.997 & 5.081\end{array}$

$\%$ Gravel Sand Silt Clay $\begin{array}{llll}0.12 & 8.56 & 90.69 & 0.62\end{array}$

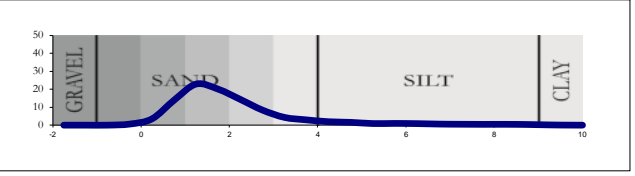

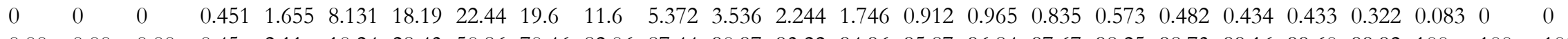

Frequency \%

Cumulative $\%$

RUAWAKA TM UNIT 5 32

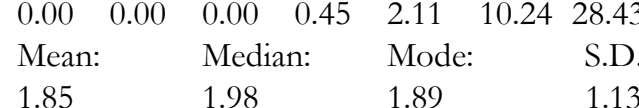

$\begin{array}{ccccccc}1.85 & & 1.98 & 1.89 & & 1.13 \\ \%> & 5 & 16 & 25 & 75 & 84 & 95\end{array}$

$\begin{array}{lllllll}5.78 & 1.177 & 1.418 & 2.661 & 3.138 & 5.014\end{array}$

$\%$ Gravel Sand Silt Clay $\begin{array}{llll}0.00 & 93.22 & 6.38 & 0.40\end{array}$

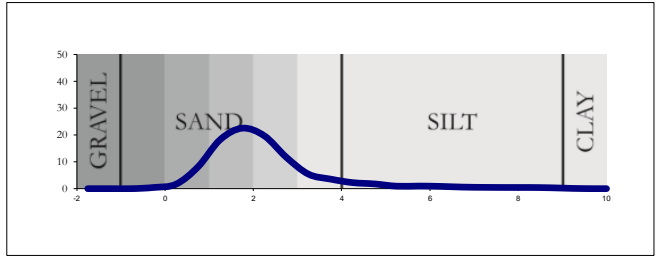

RW51

Frequency $\%$

Cumulative $\%$

Ruawak_TM SS Top_01.\$1s

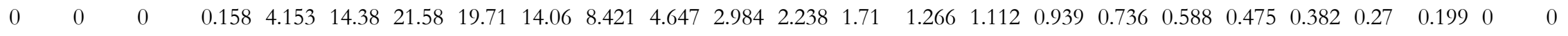
$\begin{array}{llllllllllllllllllllllllllll}0.00 & 0.00 & 0.00 & 0.16 & 4.31 & 18.69 & 40.26 & 59.97 & 74.03 & 82.45 & 87.10 & 90.08 & 92.32 & 94.03 & 95.30 & 96.41 & 97.35 & 98.09 & 98.67 & 99.15 & 99.53 & 99.80 & 100 & 100 & 100\end{array}$ Mean: Median: Mode: S.D.

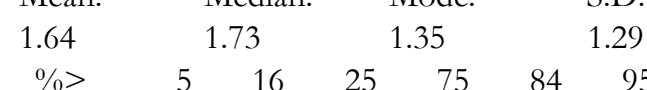
$0.535 \quad 0.9271 .155 \quad 2.546 \quad 3.137 \quad 5.374$

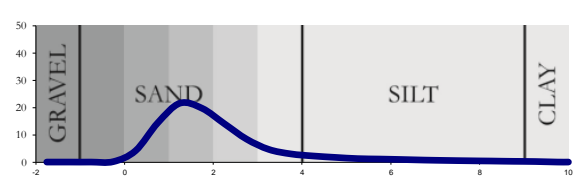


Ruawaka Section

Class midpoints

Class limits

\section{RW45}

Frequency $\%$

Cumulative \%

Ruawak_River1_21.\$1

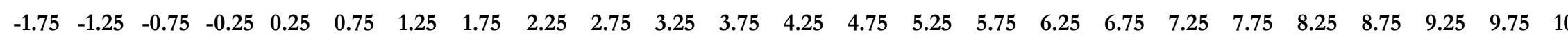
$\begin{array}{lllllllllllllllllllllllll}-2.00 & -1.50 & -1.00 & -0.50 & 0.00 & 0.50 & 1.00 & 1.50 & 2.00 & 2.50 & 3.00 & 3.50 & 4.00 & 4.50 & 5.00 & 5.50 & 6.00 & 6.50 & 7.00 & 7.50 & 8.00 & 8.50 & 9.00 & 9.50 & 10\end{array}$

\section{Sw}

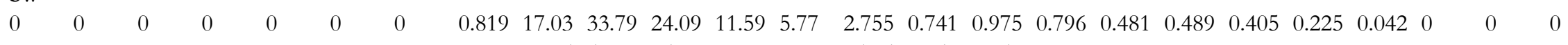

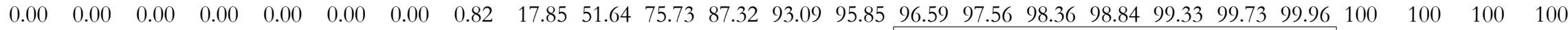
Mean: Median: Mode: S.D.

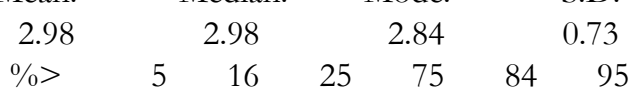

$2.213 \quad 2.464 \quad 2.6143 .477 \quad 3.815 \quad 4.773$

$\%$ Gravel Sand Silt Clay $\begin{array}{llll}0.00 & 93.09 & 6.87 & 0.04\end{array}$

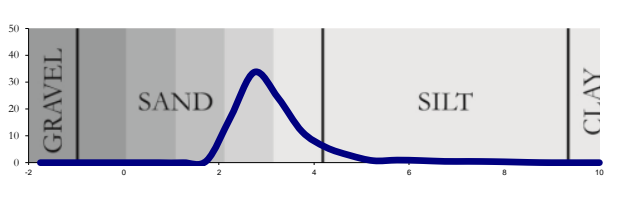

Sw

$\begin{array}{lllllllllllllllllllllllllll}0 & 0 & 0 & 0 & 0 & 0 & 0 & 0.801 & 17.29 & 34.74 & 23.57 & 10.07 & 4.458 & 2.565 & 1.009 & 1.321 & 1.174 & 0.835 & 0.789 & 0.655 & 0.504 & 0.218 & 0.006 & 0 & 0\end{array}$ $\begin{array}{lllllllllllllllllllllllll}0.00 & 0.00 & 0.00 & 0.00 & 0.00 & 0.00 & 0.00 & 0.80 & 18.09 & 52.83 & 76.40 & 86.47 & 90.92 & 93.49 & 94.50 & 95.82 & 96.99 & 97.83 & 98.62 & 99.27 & 99.78 & 99.99 & 100 & 100 & 100\end{array}$ $\begin{array}{rrrr}\text { Mean: } & \text { Median: } & \text { Mode: } & \text { S.D } \\ 2.99 & 2.96 & 2.84 & 0.87\end{array}$ $\begin{array}{lrrrrr}2.99 & & 2.96 & & 2.84 & 0.8 \\ \%> & 5 & 16 & 25 & 75 & 84\end{array}$ $2.211 \quad 2.459 \quad 2.608 \quad 3.453 \quad 3.828 \quad 5.712$

$\%$ Gravel Sand Silt Clay $\begin{array}{llll}0.00 & 90.92 & 8.85 & 0.22\end{array}$

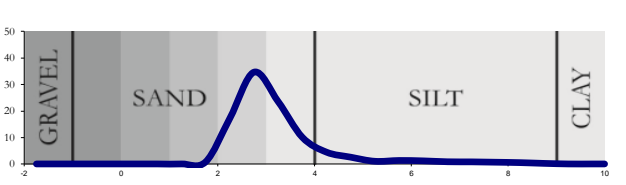

\section{$\overline{\mathrm{RW}} 43$}

Frequency $\%$

Cumulative $\%$

Ruawak_River2_23.\$1s

Frequency \%

Cumulative \%

Ruawak_River2_24.\$1s
Sp

$\begin{array}{llllllllllllllllllllllllll}0 & 0 & 0 & 0 & 0 & 0 & 0 & 0.022 & 3.632 & 21.23 & 27.97 & 13.02 & 5.346 & 5.059 & 3.646 & 4.144 & 3.965 & 3.242 & 2.758 & 2.371 & 1.971 & 1.248 & 0.366 & 0.005 & 0\end{array}$ $\begin{array}{llllllllllllllllllllllllll}0.00 & 0.00 & 0.00 & 0.00 & 0.00 & 0.00 & 0.00 & 0.02 & 3.65 & 24.89 & 52.86 & 65.88 & 71.22 & 76.28 & 79.93 & 84.07 & 88.04 & 91.28 & 94.04 & 96.41 & 98.38 & 99.63 & 99.99 & 100 & 100\end{array}$ Mean: Median: Mode: S.D.

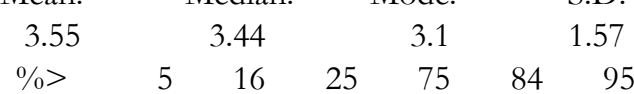
$2.5492 .837 \quad 3.002 \quad 4.857 \quad 5.991 \quad 7.693$

$\%$ Gravel Sand Silt Clay $\begin{array}{llll}0.00 & 71.22 & 27.16 & 1.62\end{array}$

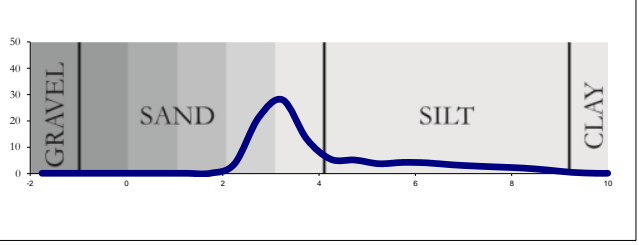

Sp

$\begin{array}{llllllllllllllllllllllll}0 & 0 & 0 & 0 & 0 & 0 & 0.023 & 3.729 & 21.35 & 27.74 & 12.96 & 5.221 & 4.944 & 3.691 & 4.179 & 4.008 & 3.295 & 2.795 & 2.392 & 1.981 & 1.267 & 0.41 & 0.013 & 0.30\end{array}$ $\begin{array}{lllllllllllllllllllllllll}0.00 & 0.00 & 0.00 & 0.00 & 0.00 & 0.00 & 0.00 & 0.02 & 3.75 & 25.11 & 52.84 & 65.81 & 71.03 & 75.97 & 79.66 & 83.84 & 87.85 & 91.14 & 93.94 & 96.33 & 98.31 & 99.58 & 99.99 & 100 & 100\end{array}$ Mean: Median: Mode: S.D $\begin{array}{lrrrrrr}3.55 & & 3.44 & & 3.1 & & 1.58 \\ \%> & 5 & 16 & 25 & 75 & 84 & 95\end{array}$ $\begin{array}{llllll}2.544 & 2.833 & 2.998 & 4.889 & 6.018 & 7.712\end{array}$
Gravel Sand Silt Clay $\begin{array}{llll}0.00 & 71.03 & 27.29 & 1.69\end{array}$

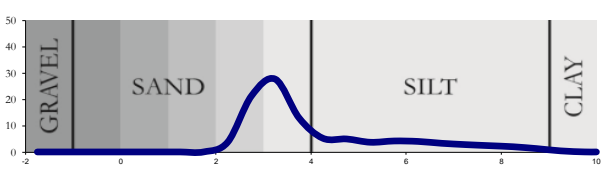




\section{RW 41}

Frequency $\%$

Cumulative \%

RW40_3 or Ab_12.\$1s

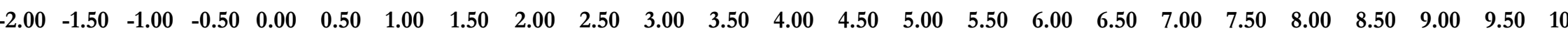

Sd

$\begin{array}{llllllllllllllllllllllllll}0 & 0 & 0 & 0 & 0.013 & 1.194 & 0.761 & 8.85 & 40.96 & 36.37 & 6.984 & 1.99 & 0.864 & 0.529 & 0.315 & 0.271 & 0.275 & 0.211 & 0.176 & 0.134 & 0.079 & 0.024 & \# \# \# & 0 & 0\end{array}$

$\begin{array}{lllllllllllllllllllllllll}0 & 0 & 0 & 0 & 0.013 & 1.208 & 1.969 & 10.82 & 51.78 & 88.15 & 95.13 & 97.12 & 97.99 & 98.51 & 98.83 & 99.1 & 99.38 & 99.59 & 99.76 & 99.9 & 99.98 & 100 & 100 & 100 & 100\end{array}$

Mean: Median: Mode: S.D.

$\begin{array}{llll}2.432 & 2.481 & 2.432 & 0.45\end{array}$

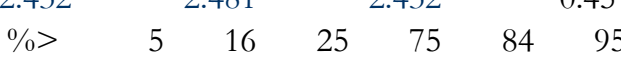

$\begin{array}{llllll}1.848 & 2.096 & 2.215 & 2.761 & 2.902 & 3.464\end{array}$

$\%$ Gravel Sand Silt Clay

$\begin{array}{llll}0.00 & 97.99 & 1.99 & 0.02\end{array}$

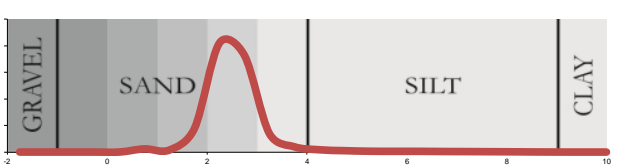

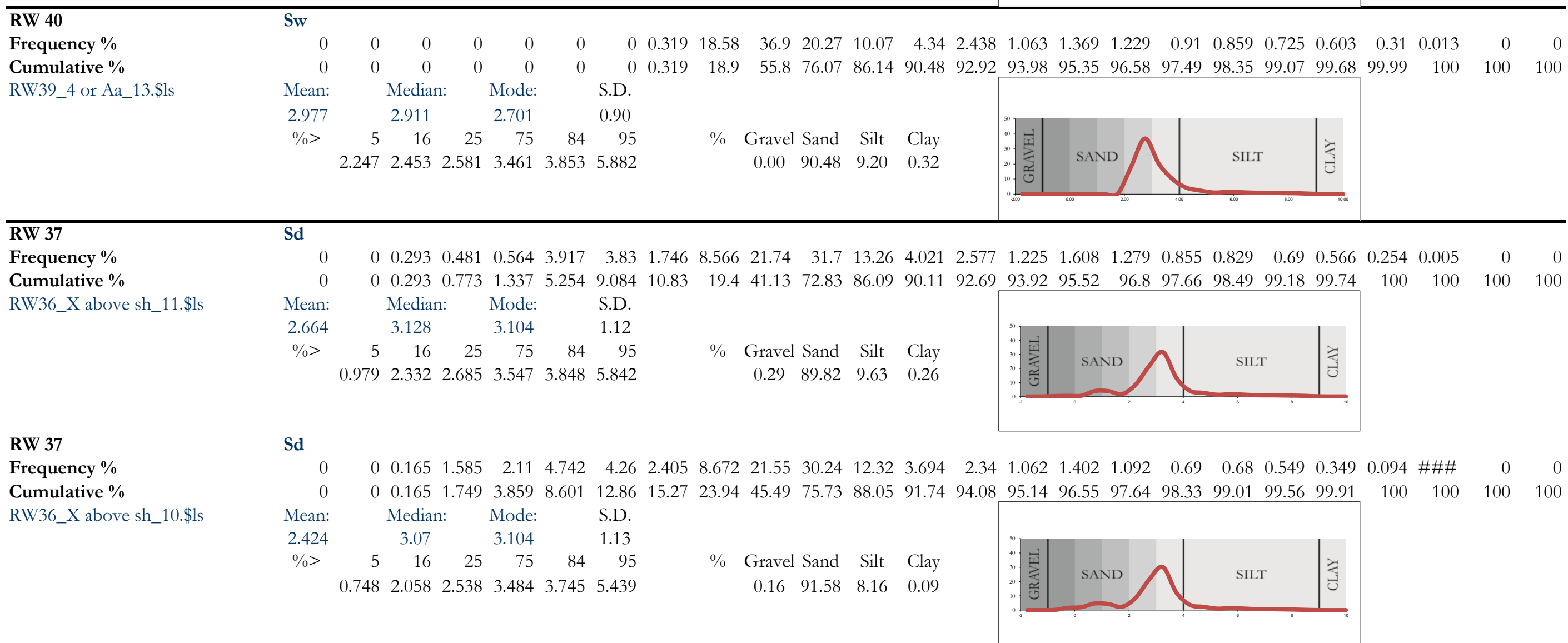


Ruawaka Section

Class midpoints

Class limits

RW 30

Frequency $\%$

Cumulative \%

RW_S_03.\$1s

\section{RW 30}

Frequency \%

Cumulative \%

RW29_S_04.\$1s

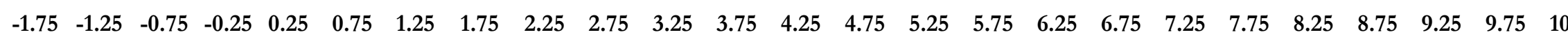
$\begin{array}{lllllllllllllllllllllllll}-2.00 & -1.50 & -1.00 & -0.50 & 0.00 & 0.50 & 1.00 & 1.50 & 2.00 & 2.50 & 3.00 & 3.50 & 4.00 & 4.50 & 5.00 & 5.50 & 6.00 & 6.50 & 7.00 & 7.50 & 8.00 & 8.50 & 9.00 & 9.50 & 10\end{array}$

Sw

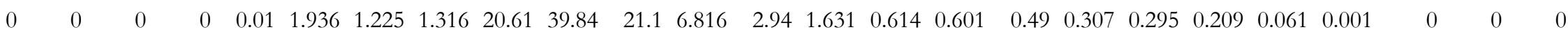
$\begin{array}{llllllllllllllllllllllllll}0 & 0 & 0 & 0 & 0.01 & 1.946 & 3.171 & 4.488 & 25.1 & 64.94 & 86.03 & 92.85 & 95.79 & 97.42 & 98.04 & 98.64 & 99.13 & 99.43 & 99.73 & 99.94 & 100 & 100 & 100 & 100 & 100\end{array}$

Mean: Median: Mode: S.D.

$\begin{array}{lrrr}2.716 & 2.808 & 2.701 & 0.61\end{array}$

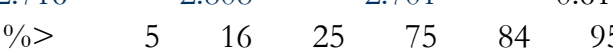

$2.032 \quad 2.3542 .499 \quad 3.166 \quad 3.412 \quad 4.33$

$\%$ Gravel Sand Silt Clay

$\begin{array}{llll}0.00 & 95.79 & 4.21 & 0.00\end{array}$

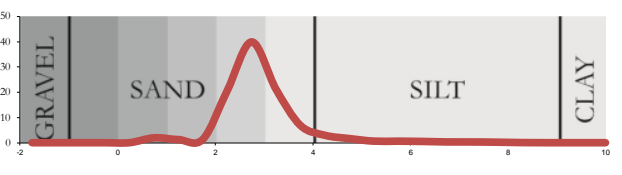

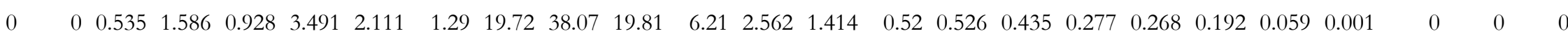

$\begin{array}{lllllllllllllllllllllllllll}0 & 0 & 0.535 & 2.121 & 3.048 & 6.539 & 8.65 & 9.94 & 29.66 & 67.73 & 87.54 & 93.75 & 96.31 & 97.72 & 98.24 & 98.77 & 99.2 & 99.48 & 99.75 & 99.94 & 100 & 100 & 100 & 100 & 100\end{array}$

Mean: Median: Mode: S.D

$\begin{array}{llll}2.364 & 2.765 & 2.701 & 0.78\end{array}$

$\begin{array}{lllllll}\%> & 5 & 16 & 25 & 75 & 84 & 95\end{array}$

$\begin{array}{llllll}0.856 & 2.243 & 2.422 & 3.123 & 3.348 & 4.199\end{array}$

$\%$ Gravel Sand Silt Clay $\begin{array}{lllll}0.53 & 95.77 & 3.69 & 0.00\end{array}$

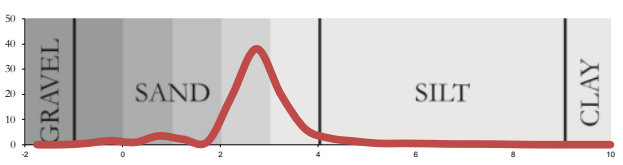

\section{RW 26}

Frequency $\%$

Cumulative $\%$

RW25_O lam_09.\$1s

RW 26

Frequency $\%$

Cumulative \%

RW25_O lam_08.\$1s

\section{Sd}

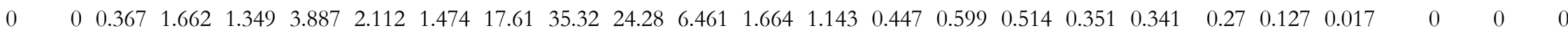
Mean: 2.358 $\%>$

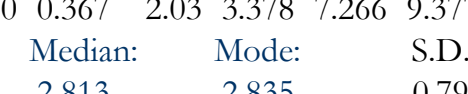

$\begin{array}{lll}2.813 & 2.835 & 0.79\end{array}$

$\begin{array}{rrrrrr}5 & 16 & 25 & 75 & 84 & 95\end{array}$

$\begin{array}{llllll}0.791 & 2.224 & 2.431 & 3.173 & 3.369 & 4.11\end{array}$
$\%$ Gravel Sand Silt Clay

$100 \quad 100 \quad 100 \quad 100$ $\begin{array}{lllll}0.37 \quad 95.82 & 3.79 & 0.02\end{array}$
Sd

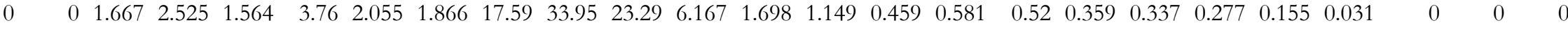
$\begin{array}{llllllllllllllllllllllllll}0 & 0 & 1.667 & 4.192 & 5.756 & 9.516 & 11.57 & 13.44 & 31.03 & 64.98 & 88.27 & 94.43 & 96.13 & 97.28 & 97.74 & 98.32 & 98.84 & 99.2 & 99.54 & 99.81 & 99.97 & 100 & 100 & 100 & 100\end{array}$ Mean: Median: Mode: S.D

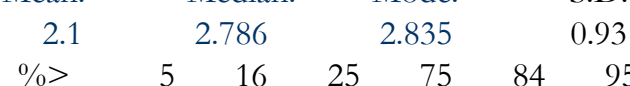
$\begin{array}{lllllll}0.068 & 2.112 & 2.373 & 3.158 & 3.356 & 4.129\end{array}$
$\% \quad$ Gravel Sand Silt Clay $\begin{array}{lllll}1.67 & 94.46 & 3.84 & 0.03\end{array}$
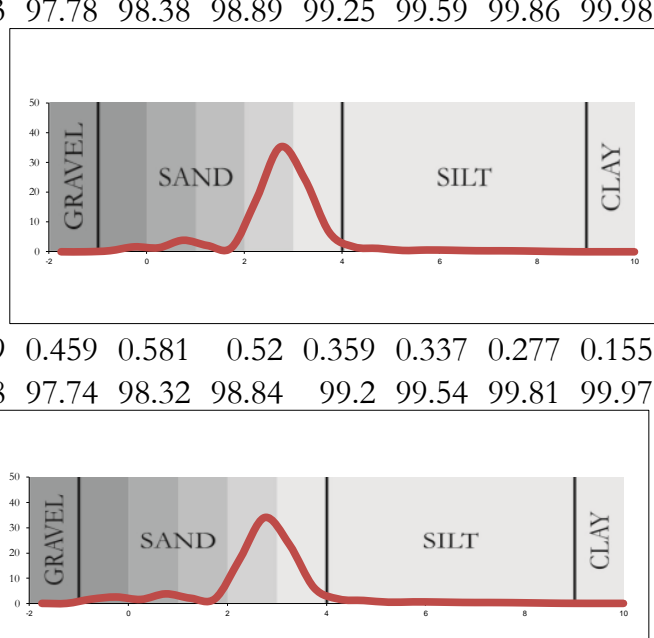


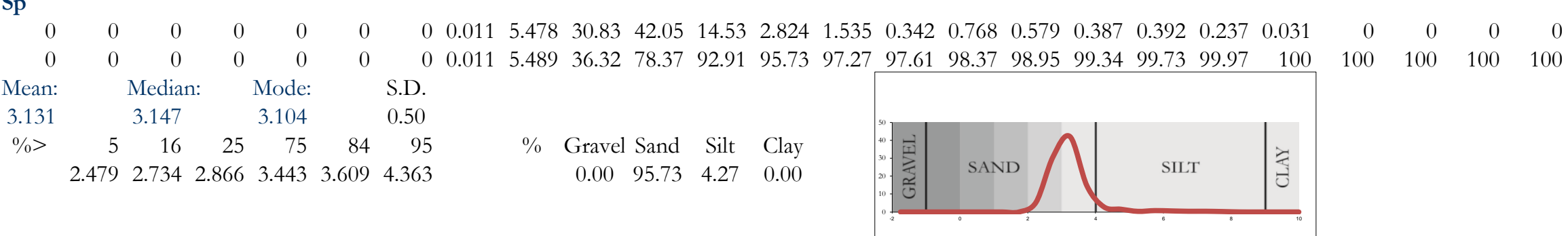

\section{RW 24}

Frequency $\%$

Cumulative \%

RW24_Nmidbase_06.\$1

Frequency \%

Cumulative \%

RW24_Nmidbase_05.\$1

\section{Sd}

0

Mean:

$\%>$

$\begin{array}{rrrrrr}5 & 16 & 25 & 75 & 84 & 95 \\ 1.296 & 2.552 & 2.811 & 4.064 & 4.86 & 6.967\end{array}$

$\begin{array}{lllllllllllllllllllllllll}0 & 0.084 & 0.339 & 0.378 & 2.454 & 2.337 & 1.737 & 7.187 & 19.54 & 25.83 & 14.13 & 6.405 & 4.661 & 2.805 & 2.704 & 2.495 & 2.046 & 1.723 & 1.419 & 1.048 & 0.567 & 0.118 & \# \# \# & 0\end{array}$ $\begin{array}{lllllllllllllllllllllllll}0 & 0.084 & 0.423 & 0.801 & 3.25 & 5.592 & 7.329 & 14.52 & 34.06 & 59.88 & 74.01 & 80.41 & 85.08 & 87.88 & 90.59 & 93.08 & 95.13 & 96.85 & 98.27 & 99.31 & 99.88 & 100 & 100 & 100\end{array}$

Median: Mode: S.D.

$\%$ Gravel Sand Silt Clay $\begin{array}{llll}0.08 & 80.33 & 18.90 & 0.69\end{array}$

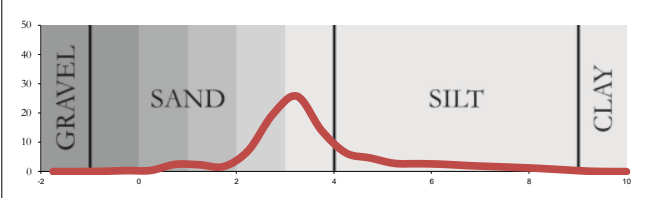

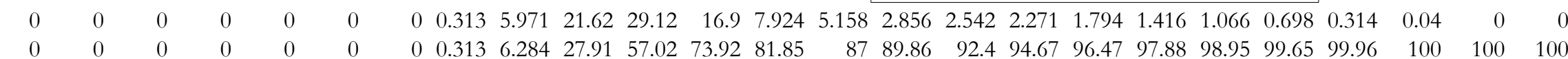
Mean: Median: $\quad$ Mode:

$\begin{array}{llll}3.378 & 3.368 & 3.104 & 1.10\end{array}$

$\%>\quad \begin{array}{lllllllll}5 & 16 & 25 & 75 & 84 & 95 & \% & \text { Gravel Sand } & \text { Silt } \quad \text { Clay }\end{array}$ $2.438 \quad 2.775 \quad 2.949 \quad 4.055 \quad 4.677 \quad 6.583$

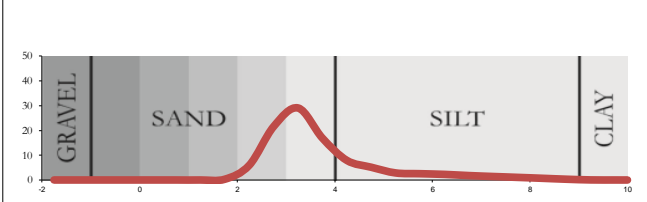

RW 18 Sd

Frequency \%

Cumulative \%

$\begin{array}{lllllllllllllllllllllllllll}0 & 0 & 0 & 0 & 0 & 0 & 0 & 0.057 & 2.64 & 11.77 & 23.13 & 19.62 & 9.054 & 5.397 & 4.125 & 5.107 & 5.058 & 4.125 & 3.422 & 2.813 & 2.188 & 1.255 & 0.239 & \# \# \# \quad 0\end{array}$

$\begin{array}{lllllllllllllllllllllllllll}0.00 & 0.00 & 0.00 & 0.00 & 0.00 & 0.00 & 0.00 & 0.06 & 2.70 & 14.47 & 37.60 & 57.22 & 66.27 & 71.67 & 75.79 & 80.90 & 85.96 & 90.08 & 93.50 & 96.32 & 98.51 & 99.76 & 100 & 100 & 100\end{array}$

Penin_GB-1_42

Mean: Median: Mode: S.D.

\begin{tabular}{llllllr}
3.8 & & 3.78 & \multicolumn{2}{ll}{3.37} & & 1.59 \\
$\%>$ & 5 & 16 & 25 & 75 & 84 & 95
\end{tabular}

$2.6493 .0443 .2465 .408 \quad 6.295 \quad 7.752$

$\%$ Gravel Sand Silt Clay

$\begin{array}{llll}0.00 & 66.27 & 32.23 & 1.49\end{array}$

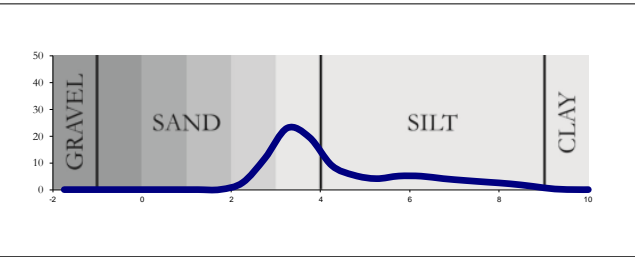



$\begin{array}{llllllllllllllllllllllllll}0.00 & 0.00 & 0.00 & 0.00 & 0.00 & 0.00 & 0.00 & 0.35 & 4.72 & 19.23 & 45.66 & 66.22 & 75.10 & 79.88 & 83.10 & 86.83 & 90.32 & 93.11 & 95.43 & 97.38 & 98.89 & 99.78 & 100 & 100 & 100\end{array}$ Mean: Median: Mode: S.D.

$$
\begin{aligned}
& \begin{array}{llll}
3.58 & 3.58 & 3.37 & 1.42
\end{array} \\
& \begin{array}{lllllll}
\%> & 5 & 16 & 25 & 75 & 84 & 95
\end{array}
\end{aligned}
$$

$\%$ Gravel Sand Silt Clay

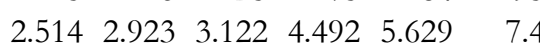
$\begin{array}{llll}0.00 & 75.10 & 23.79 & 1.11\end{array}$

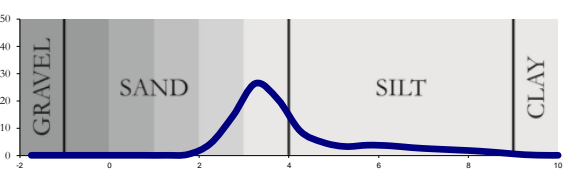

\section{RW 18}

Frequency $\%$

Cumulative \%

Penin_underGSB1_32.\$1
Sd

$\begin{array}{lllllllllllllllllllllllllll}0 & 0 & 0 & 0 & 0 & 0 & 0 & 0.017 & 2.405 & 11.98 & 17.66 & 16.54 & 18.37 & 15.78 & 6.517 & 3.367 & 2.476 & 1.601 & 1.117 & 0.873 & 0.696 & 0.446 & 0.155 & 0.007 & 0\end{array}$ $\begin{array}{lllllllllllllllllllllllll}0.00 & 0.00 & 0.00 & 0.00 & 0.00 & 0.00 & 0.00 & 0.02 & 2.42 & 14.41 & 32.06 & 48.61 & 66.97 & 82.75 & 89.26 & 92.63 & 95.11 & 96.71 & 97.82 & 98.70 & 99.39 & 99.84 & 99.99 & 100 & 100\end{array}$

Mean: Median: Mode: S.D.

$\begin{array}{llll}3.8 & 4.04 & 4.45 & 1.08\end{array}$

$\begin{array}{rrrrrrr}\%> & 5 & 16 & 25 & 75 & 84 & 95 \\ & 2.652 & 3.049 & 3.303 & 4.72 & 5.06 & 6.474\end{array}$

$\%$ Gravel Sand Silt Clay $\begin{array}{llll}0.00 & 66.97 & 32.42 & 0.61\end{array}$

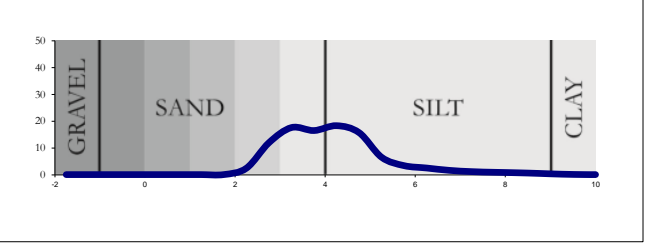

RW 18

Frequency $\%$

Cumulative $\%$

GSB1_33.\$1s

$\begin{array}{lllllllllllllllllllllllllll}0 & 0 & 0 & 0 & 0 & 0 & 0 & 0.017 & 2.491 & 12.82 & 18.89 & 16.83 & 17.56 & 15.03 & 6.218 & 3.214 & 2.348 & 1.505 & 1.048 & 0.821 & 0.652 & 0.411 & 0.134 & 0 & 0\end{array}$ $\begin{array}{llllllllllllllllllllllllll}0.00 & 0.00 & 0.00 & 0.00 & 0.00 & 0.00 & 0.00 & 0.02 & 2.51 & 15.33 & 34.22 & 51.05 & 68.61 & 83.64 & 89.86 & 93.08 & 95.42 & 96.93 & 97.98 & 98.80 & 99.45 & 99.86 & 100 & 100 & 100\end{array}$ Mean: Median: Mode: $\quad$ S.D $\begin{array}{llll}3.76 & 3.97 & 3.24 & 1.07\end{array}$

$\begin{array}{lllllll}\%> & 5 & 16 & 25 & 75 & 84 & 95\end{array}$ $\begin{array}{llllll}2.642 & 3.02 & 3.258 & 4.681 & 5.017 & 6.392\end{array}$

$\%$ Gravel Sand Silt Clay $\begin{array}{llll}0.00 & 68.61 & 30.84 & 0.55\end{array}$

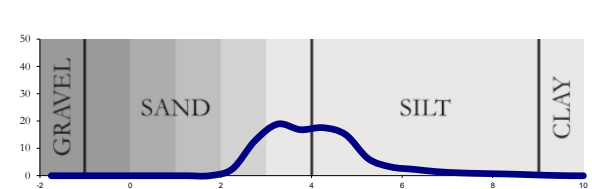

RW 18

Frequency \%

Cumulative \%

Penin_clay_36.\$1s $\begin{array}{lllllllllllllllllllllllllll}0 & 0 & 0.752 & 1.349 & 3.96 & 4.775 & 4.801 & 8.385 & 9.293 & 7.368 & 5.217 & 3.385 & 3.758 & 3.258 & 3.853 & 4.336 & 4.048 & 4.101 & 5.062 & 6.419 & 6.598 & 4.768 & 2.578 & 1.936\end{array}$ $\begin{array}{llllllllllllllllllllllllll}0.00 & 0.00 & 0.00 & 0.75 & 2.10 & 6.06 & 10.83 & 15.64 & 24.02 & 33.31 & 40.68 & 45.90 & 49.28 & 53.04 & 56.30 & 60.15 & 64.49 & 68.53 & 72.63 & 77.70 & 84.12 & 90.71 & 95.48 & 98.06 & 100\end{array}$ Mean: Median: Mode: S.D.

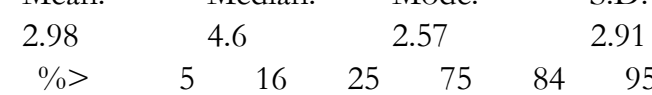
$\begin{array}{llllll}0.901 & 2.026 & 2.549 & 7.751 & 8.491 & 9.436\end{array}$
$\% \quad$ Gravel Sand Silt Clay $\begin{array}{llll}0.00 & 49.28 & 34.83 & 15.88\end{array}$

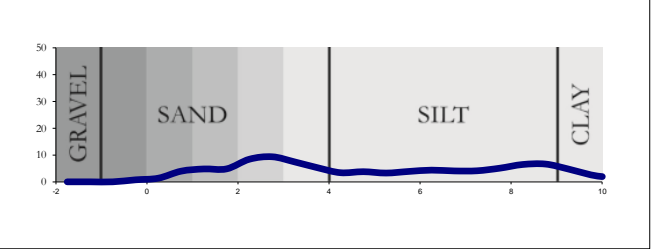


Penin_clay_37

Mean: $\quad$ Median: Mode: S.D.

$$
\begin{array}{lllll}
2.92 & 4.56 & 2.43 & 2.86
\end{array}
$$

$\%>\quad 5 \quad \begin{array}{llllll}\% & 16 & 25 & 75 & 84 & 95\end{array}$

$\begin{array}{llllll}0.844 & 1.96 & 2.502 & 7.449 & 8.309 & 9.257\end{array}$

$\%$ Gravel Sand Silt Clay

$\begin{array}{llll}0.00 & 49.52 & 36.91 & 13.57\end{array}$

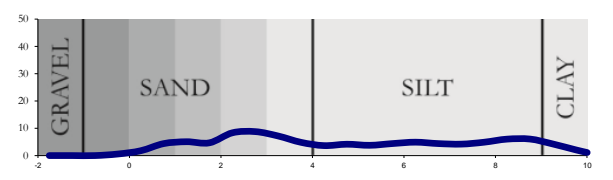

\section{RW 14}

Frequency $\%$

Cumulative \%

Penin_underGSB3 34.\$1

\section{Sp}

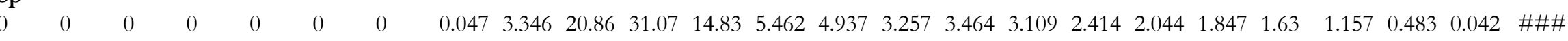

$\begin{array}{llll}\text { Mean: } & \text { Median: } & \text { Mode: } & \text { S.D. } \\ 3.5 & 3.4 & 3.1 & 1.42\end{array}$

3.5

$\%$

$\%$ Gravel Sand Silt Clay

$\begin{array}{llllll}2.564 & 2.855 & 3.013 & 4.44 & 5.529 & 7.541\end{array}$ $\begin{array}{llll}0.00 & 75.62 & 22.70 & 1.68\end{array}$

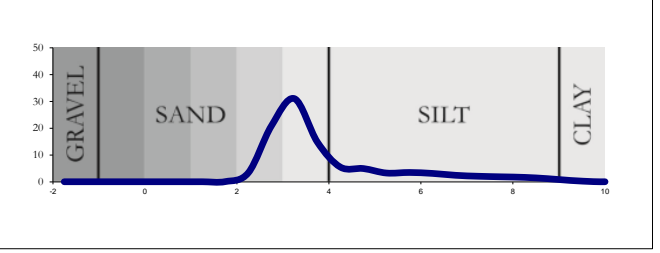

RW 14

Frequency \%

Cumulative \%

Penin underGSB3 35.\$1s

\section{$\mathrm{Sp}$}

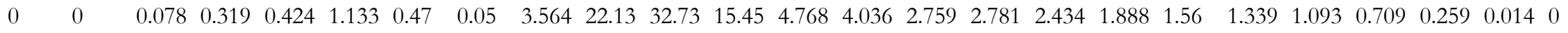

$\begin{array}{lllllllllllllllllllllllll}0.00 & 0.00 & 0.08 & 0.40 & 0.82 & 1.95 & 2.42 & 2.47 & 6.04 & 28.17 & 60.90 & 76.36 & 81.12 & 85.16 & 87.92 & 90.70 & 93.14 & 95.02 & 96.59 & 97.92 & 99.02 & 99.73 & 99.99 & 100 & 100\end{array}$

Mean: $\quad$ Median: Mode: S.D.

$\begin{array}{llll}3.2 & 3.32 & 3.1 & 1.20\end{array}$

$\begin{array}{lllllll}\%> & 5 & 16 & 25 & 75 & 84 & 95\end{array}$

$\begin{array}{llllll}2.431 & 2.79 & 2.95 & 3.917 & 4.838 & 6.993\end{array}$

$\%$ Gravel Sand Silt Clay $\begin{array}{llll}0.08 & 81.05 & 17.89 & 0.98\end{array}$

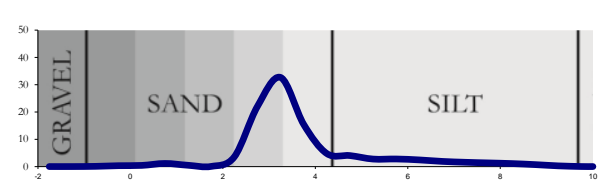

RW 9

Frequency \%

Cumulative \%

SBal

$\begin{array}{lllllllllllllllllllllllll}0 & 1.106 & 2.692 & 4.105 & 5.74 & 4.352 & 7.106 & 17.81 & 18.2 & 9.898 & 6.665 & 6.419 & 4.965 & 2.916 & 2.184 & 1.724 & 1.3 & 1.049 & 0.838 & 0.592 & 0.294 & 0.05 & \# \# \# & 0\end{array}$

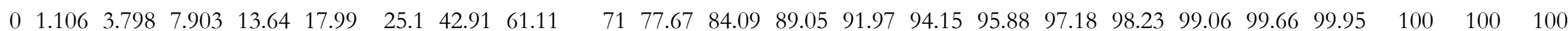

Sample_Xeno_40.\$1s

Mean: Median: Mode: S.D.

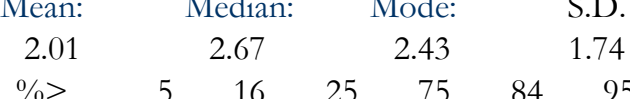

$\begin{array}{llllll}0.132 & 1.211 & 1.989 & 3.79 & 4.489 & 6.223\end{array}$

$\%$ Gravel Sand Silt Clay

$\begin{array}{lllll}1.11 & 82.98 & 15.57 \quad 0.34\end{array}$

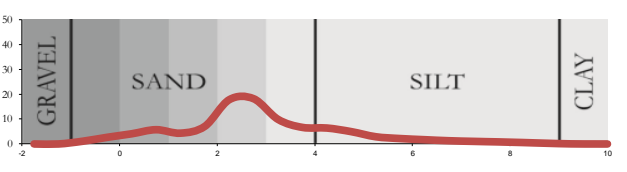


RW 9

Frequency $\%$

Cumulative \%

Sample_Xeno_41.\$1s $\begin{array}{llllllllllllllllllllllllllll}-2.00 & -1.50 & -1.00 & -0.50 & 0.00 & 0.50 & 1.00 & 1.50 & 2.00 & 2.50 & 3.00 & 3.50 & 4.00 & 4.50 & 5.00 & 5.50 & 6.00 & 6.50 & 7.00 & 7.50 & 8.00 & 8.50 & 9.00 & 9.50 & 10\end{array}$

SBal

$\begin{array}{llllllllllllllllllllllll}0 & 1.249 & 2.993 & 3.786 & 5.429 & 4.588 & 7.545 & 18.74 & 18.11 & 8.565 & 4.94 & 4.967 & 4.7 & 3.322 & 2.754 & 2.252 & 1.735 & 1.459 & 1.243 & 0.963 & 0.545 & 0.118 & \# \# \# \# & 0\end{array}$

$\begin{array}{lllllllllllllllllllllllll}0 & 0 & 1.249 & 4.241 & 8.028 & 13.46 & 18.04 & 25.59 & 44.33 & 62.44 & 71 & 75.94 & 80.91 & 85.61 & 88.93 & 91.68 & 93.94 & 95.67 & 97.13 & 98.37 & 99.34 & 99.88 & 100 & 100 & 100\end{array}$

Mean: Median: Mode: S.D.

$\begin{array}{llll}1.995 & 2.63 & 2.432 & 1.92\end{array}$

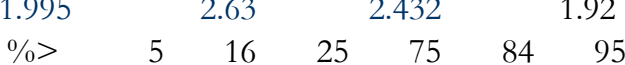

$\begin{array}{llllll}0.07 & 1.22 & 1.972 & 3.893 & 4.809 & 6.79\end{array}$

$\%$ Gravel Sand Silt Clay

$1.25 \quad 79.66 \quad 18.43 \quad 0.66$

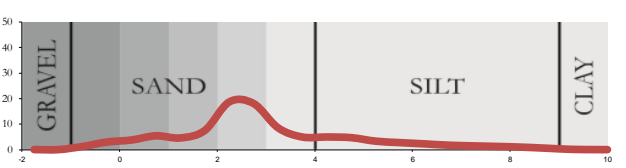

\section{RW 8}

Frequency $\%$

Cumulative \%

Xeno2 38.\$1s

\section{Sp}

$\begin{array}{lllllllllllllllllllllllllllll}0 & 0 & 0 & 0 & 0.046 & 1.362 & 2.107 & 11.66 & 27.65 & 21.03 & 7.675 & 4.354 & 4.159 & 4.095 & 3.675 & 3.408 & 2.825 & 2.106 & 1.565 & 1.126 & 0.734 & 0.357 & 0.066 & \# \# \# & 0\end{array}$

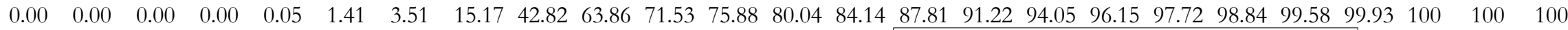

Mean: Median: Mode: S.D.

$\begin{array}{llll}2.66 & 2.63 & 2.3 & 1.51\end{array}$

$\begin{array}{lllllll}\%> & 5 & 16 & 25 & 75 & 84 & 95\end{array}$

$\begin{array}{llllll}1.64 & 2.018 & 2.195 & 3.895 & 4.982 & 6.708\end{array}$
\% Gravel Sand Silt Clay $\begin{array}{llll}0.00 & 80.04 & 19.53 & 0.42\end{array}$

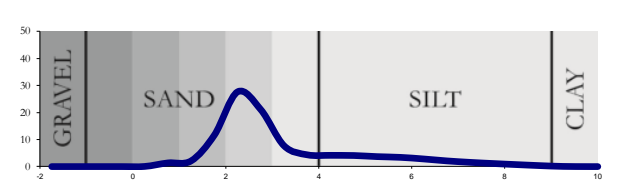

\section{RW 8}

Frequency $\%$

Cumulative $\%$

Xeno2_39

\section{Sp}

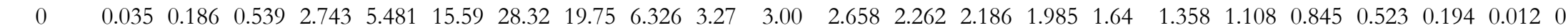
$\begin{array}{llllllllllllllllllllllllll}0.00 & 0.00 & 0.04 & 0.22 & 0.76 & 3.50 & 8.98 & 24.57 & 52.89 & 72.64 & 78.96 & 82.23 & 85.23 & 87.89 & 90.15 & 92.34 & 94.32 & 95.96 & 97.32 & 98.43 & 99.27 & 99.79 & 99.99 & 100 & 100\end{array}$ Mean: Median: Mode: S.D. $\begin{array}{llll}2.37 & 2.45 & 2.3 & 1.46\end{array}$ $\%>\quad \begin{array}{llllll}5 & 16 & 25 & 75 & 84 & 95\end{array}$ $\begin{array}{lllllll}1.171 & 1.792 & 2.008 & 3.123 & 4.286 & 6.696\end{array}$
$\%$ Gravel Sand Silt Clay $\begin{array}{llll}0.04 & 85.19 & 14.04 & 0.73\end{array}$

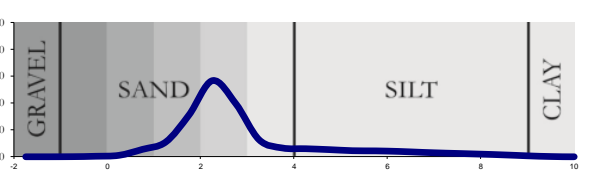

RW 7

Frequency \%

Cumulative \%

Ruawak_BelowXeno_20.\$1 $\begin{array}{lllllllllllllllllllllllll}0 & 0 & 0 & 0 & 0 & 0 & 0 & 1.703 & 25.35 & 38.91 & 16.31 & 5.757 & 2.682 & 2.245 & 1.23 & 1.379 & 1.248 & 0.887 & 0.795 & 0.678 & 0.55 & 0.273 & 0.011 & 0 & 0\end{array}$ $\begin{array}{lllllllllllllllllllllllll}0.00 & 0.00 & 0.00 & 0.00 & 0.00 & 0.00 & 0.00 & 1.70 & 27.05 & 65.96 & 82.26 & 88.02 & 90.70 & 92.95 & 94.18 & 95.56 & 96.81 & 97.69 & 98.49 & 99.17 & 99.72 & 99.99 & 100 & 100 & 100\end{array}$ Mean: Median: Mode: S.D. $\begin{array}{llll}2.84 & 2.78 & 2.7 & 0.88\end{array}$ $\%>\quad \begin{array}{llllll}5 & 16 & 25 & 75 & 84 & 95\end{array}$ $\begin{array}{llllll}2.126 & 2.345 & 2.471 & 3.19 & 3.619 & 5.811\end{array}$
$\% \quad$ Gravel Sand Silt Clay $\begin{array}{llll}0.00 & 90.70 & 9.01 & 0.28\end{array}$

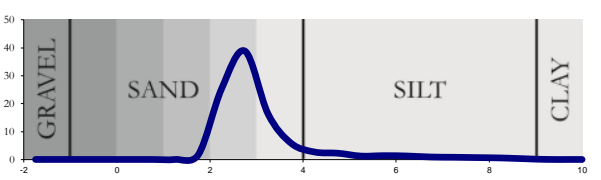


RW 7

Frequency \%

Cumulative \%

Ruawak_BelowXeno_21.\$1 $\begin{array}{lllllllllllllllllllllllll}0 & 0 & 0 & 0 & 0 & 0 & 0 & 1.235 & 23.65 & 37.71 & 16.29 & 6.119 & 3.215 & 2.78 & 1.579 & 1.726 & 1.584 & 1.138 & 1.02 & 0.842 & 0.72 & 0.379 & 0.016 & 0 & 0\end{array}$ $\begin{array}{llllllllllllllllllllllllll}0.00 & 0.00 & 0.00 & 0.00 & 0.00 & 0.00 & 0.00 & 1.23 & 24.89 & 62.60 & 78.88 & 85.00 & 88.22 & 91.00 & 92.58 & 94.30 & 95.89 & 97.02 & 98.04 & 98.89 & 99.61 & 99.98 & 100 & 100 & 100\end{array}$ Mean: Median: Mode: S.D.

$$
\begin{array}{lllllll}
2.9 & & 2.82 & 2.7 & & 0.99 \\
0> & 5 & 16 & 25 & 75 & 84 & 95
\end{array}
$$$$
\begin{array}{lllllll}
\%> & 5 & 16 & 25 & 75 & 84 & 95
\end{array}
$$

$\begin{array}{llllll}2.151 & 2.373 & 2.501 & 3.3 & 3.894 & 6.197\end{array}$
$\%$ Gravel Sand Silt Clay $\begin{array}{llll}0.00 & 88.22 & 11.39 & 0.39\end{array}$

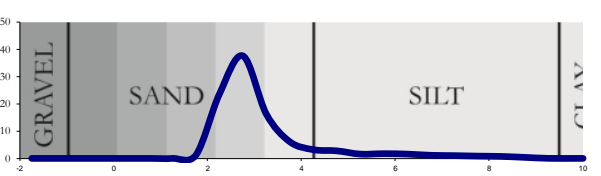

\section{RW 4 Top}

Frequency $\%$

Cumulative \%

Ruawak_Smple3 29.\$1s

\section{RW 4 Top}

Frequency \%

Cumulative \%

Ruawak_Smple3 30.\$1

RW 4 Top

Frequency \%

Cumulative \%

Ruawak_Smple3 31.\$1

\section{Sd}

$\begin{array}{llllllllllllllllllllllllll}0 & 0 & 0 & 0 & 0.046 & 4.486 & 6.904 & 6.05 & 12.78 & 27.13 & 27.71 & 9.912 & 2.381 & 1.055 & 0.202 & 0.437 & 0.344 & 0.233 & 0.213 & 0.105 & 0.006 & 0 & 0 & 0 & 0\end{array}$ $\begin{array}{lllllllllllllllllllllllll}0.00 & 0.00 & 0.00 & 0.00 & 0.05 & 4.53 & 11.44 & 17.49 & 30.27 & 57.40 & 85.11 & 95.02 & 97.40 & 98.46 & 98.66 & 99.10 & 99.44 & 99.68 & 99.89 & 99.99 & 100 & 100 & 100 & 100 & 100\end{array}$

Mean: Median: Mode: S.D.

$\begin{array}{llll}2.49 & 2.89 & 2.97 & 0.84\end{array}$

$\%>\quad \begin{array}{lllllr}5 & 16 & 25 & 75 & 84 & 95\end{array}$

$\begin{array}{llllll}1.029 & 1.908 & 2.334 & 3.28 & 3.47 & 3.997\end{array}$

$\%$ Gravel Sand Silt Clay $\begin{array}{llll}0.00 & 97.40 & 2.60 & 0.00\end{array}$

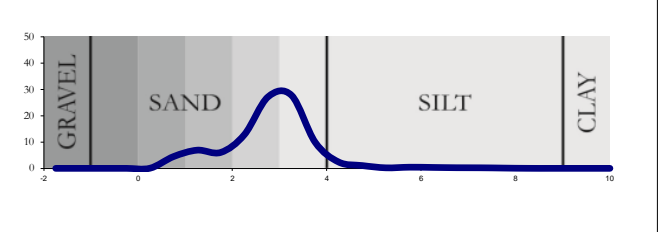

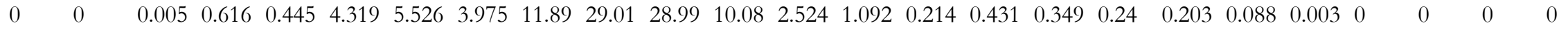
$\begin{array}{llllllllllllllllllllllllll}0.00 & 0.00 & 0.00 & 0.62 & 1.07 & 5.38 & 10.91 & 14.88 & 26.77 & 55.78 & 84.77 & 94.85 & 97.38 & 98.47 & 98.69 & 99.12 & 99.47 & 99.71 & 99.91 & 100 & 100 & 100 & 100 & 100 & 100\end{array}$ Mean: Median: Mode: $\quad$ S.D $\begin{array}{llll}2.48 & 2.92 & 2.97 & 0.81\end{array}$ $\%>\quad \begin{array}{llllll}0 & 16 & 25 & 75 & 84 & 95\end{array}$ $\begin{array}{llllll}0.973 & 2.077 & 2.445 & 3.291 & 3.479 & 4.02\end{array}$

$\%$ Gravel Sand Silt Clay $\begin{array}{llll}0.00 & 97.37 & 2.62 & 0.00\end{array}$

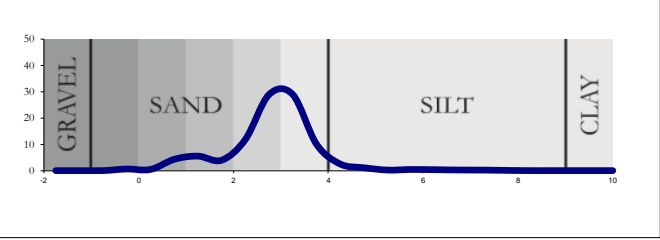

Sd

$\begin{array}{llllllllllllllllllllllllll}0 & 0 & 0 & 0 & 0.005 & 2.856 & 3.695 & 2.561 & 11.66 & 30.02 & 31.99 & 11.64 & 2.835 & 1.223 & 0.216 & 0.458 & 0.378 & 0.252 & 0.168 & 0.044 & \# \# \# \quad 0 & 0 & 0 & 0\end{array}$ $\begin{array}{llllllllllllllllllllllllll}0.00 & 0.00 & 0.00 & 0.00 & 0.00 & 2.86 & 6.56 & 9.12 & 20.78 & 50.80 & 82.78 & 94.43 & 97.26 & 98.48 & 98.70 & 99.16 & 99.54 & 99.79 & 99.96 & 100 & 100 & 100 & 100 & 100 & 100\end{array}$ Mean: Median: Mode: S.D $\begin{array}{llll}2.71 & 2.99 & 2.97 & 0.73\end{array}$ $\%>\quad \begin{array}{llllll}5 & 16 & 25 & 75 & 84 & 95\end{array}$ $\begin{array}{llllll}1.199 & 2.355 & 2.594 & 3.346 & 3.529 & 4.073\end{array}$

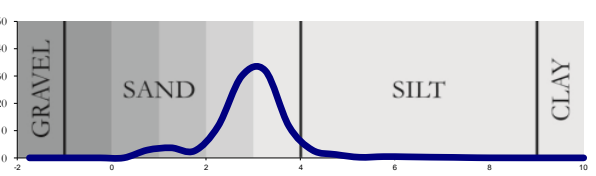


Ruawaka Section

Class midpoints

Class limits

RW 4 Centre

Frequency $\%$

Cumulative \%

Ruawak_Smple2_27.\$1s

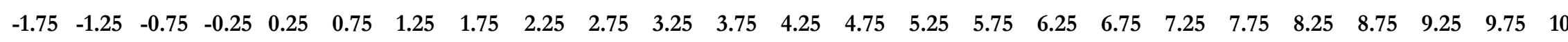

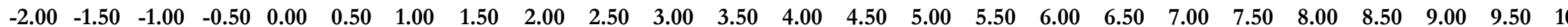

\section{Sd}

$\begin{array}{lllllllllllllllllllllllll}0 & 0 & 0 & 0 & 0 & 0 & 0 & 0.184 & 8.233 & 26.87 & 30.43 & 12.47 & 5.621 & 4.342 & 2.044 & 2.428 & 2.148 & 1.491 & 1.41 & 1.094 & 0.858 & 0.379 & 0.004 & 0 & 0\end{array}$ $\begin{array}{lllllllllllllllllllllllll}0 & 0 & 0 & 0 & 0 & 0 & 0 & 0.184 & 8.417 & 35.29 & 65.72 & 78.18 & 83.8 & 88.14 & 90.19 & 92.62 & 94.76 & 96.25 & 97.66 & 98.76 & 99.62 & 100 & 100 & 100 & 100\end{array}$ Mean: Median: Mode: S.D.

$\begin{array}{lrrr}3.26 & 3.21 & 3.10 & 1.09\end{array}$

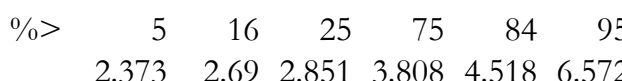

$\%$ Gravel Sand Silt Clay $\begin{array}{llll}0.00 & 83.80 & 15.81 & 0.38\end{array}$

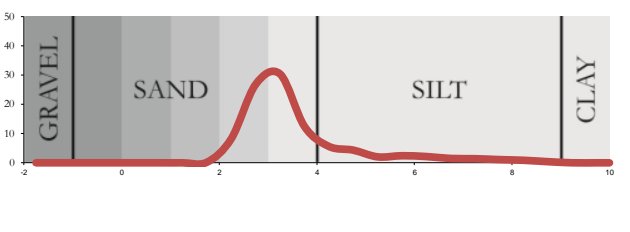

RW 4 Centre

Frequency $\%$

Cumulative \%

Ruawak_Smple2 28.\$1

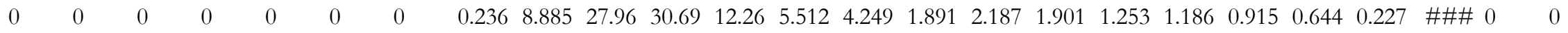
$\begin{array}{lllllllllllllllllllllllllll}0.00 & 0.00 & 0.00 & 0.00 & 0.00 & 0.00 & 0.00 & 0.24 & 9.12 & 37.08 & 67.77 & 80.03 & 85.55 & 89.79 & 91.68 & 93.87 & 95.77 & 97.03 & 98.21 & 99.13 & 99.77 & 100 & 100 & 100 & 100\end{array}$ Mean: Median: Mode: S.D

$\begin{array}{llll}\text { Mean: } & \text { Median: } & \text { Mode: } & \text { S.D. } \\ 3.22 & 3.18 & 2.97 & 1.02\end{array}$ $\begin{array}{rrrrrrr}\%> & 5 & 16 & 25 & 75 & 84 & 95 \\ & 2.351 & 2.667 & 2.827 & 3.721 & 4.363 & 6.265\end{array}$
$\%$ Gravel Sand Silt Clay $\begin{array}{lllll}0.00 & 85.55 & 14.23 & 0.23\end{array}$

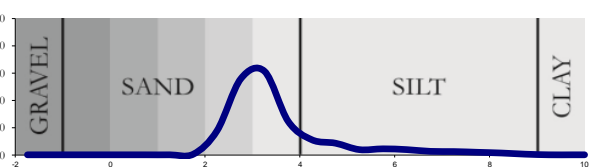

RW 2

Frequency $\%$

Cumulative $\%$

Ruawak_Unit1sand_19.\$1s
$\mathrm{Sp}$

0

$\begin{array}{llllllllllllllllllllllll}0 & 0 & 0 & 0 & 0 & 0 & 1.89 & 16.62 & 37.78 & 23.26 & 7.121 & 3.523 & 1.678 & 2.323 & 1.741 & 1.156 & 1.133 & 0.896 & 0.643 & 0.233 & 0 & 0 & 0 & 0\end{array}$ $\begin{array}{lllllllllllllllllllllllll}0.00 & 0.00 & 0.00 & 0.00 & 0.00 & 0.00 & 0.00 & 0.00 & 1.89 & 18.51 & 56.29 & 79.55 & 86.67 & 90.20 & 91.87 & 94.20 & 95.94 & 97.09 & 98.23 & 99.12 & 99.77 & 100 & 100 & 100 & 100\end{array}$ Mean: Median: Mode: S.D

$\begin{array}{llll}3.45 & 3.42 & 3.37 & 0.87\end{array}$

$\%>\quad \begin{array}{llllll}\% & 16 & 25 & 75 & 84 & 95\end{array}$

$2.6592 .9543 .099 \quad 3.832 \quad 4.295 \quad 6.198$

$\%$ Gravel Sand Silt Clay $\begin{array}{llll}0.00 & 86.67 & 13.09 & 0.23\end{array}$

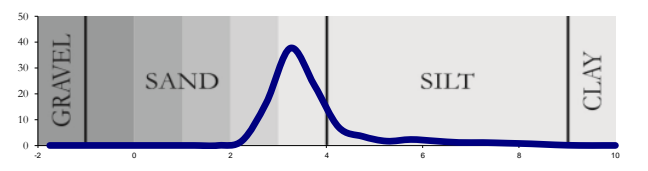

RW 2

Frequency \%

Cumulative \%

Ruawak_Unit1sand_18.\$1s

Sp

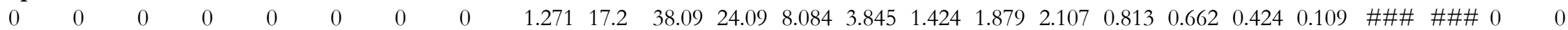
$\begin{array}{llllllllllllllllllllllllll}0.00 & 0.00 & 0.00 & 0.00 & 0.00 & 0.00 & 0.00 & 0.00 & 1.27 & 18.47 & 56.56 & 80.65 & 88.74 & 92.58 & 94.01 & 95.88 & 97.99 & 98.80 & 99.47 & 99.89 & 100 & 100 & 100 & 100 & 100\end{array}$ Mean: Median: Mode: S.D. $\begin{array}{cccccc}3.43 & 3.41 & 3.37 & 0.77 \\ 0 & 5 & 16 & 25 & 75 & 84\end{array}$ $\begin{array}{rrrrrr}5 & 16 & 25 & 75 & 84 & 95 \\ .682 & 2.956 & 3.098 & 3.816 & 4.18 & 5.768\end{array}$

$\%$ Gravel Sand Silt Clay $\begin{array}{lllll}0.00 & 88.74 & 11.26 & 0.00\end{array}$

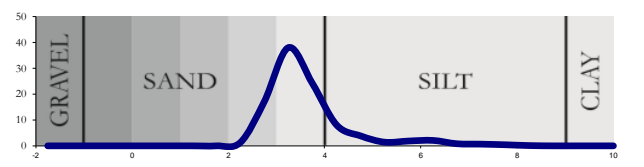


Ruakokopatuna Bridge Section

Class midpoints

Class limits

RK 13 Top

Frequency \%

Cumulative \%

Ruakok_Unit12abov_07.\$1

\section{RK 13 Top}

Frequency $\%$

Cumulative \%

Ruakok_Unit12abov_08.\$1

\section{RK 13 Top}

Frequency \%

Cumulative \%

Ruakok_Unit12abov_09.\$1s

\section{RK 13 Top}

Frequency \%

Cumulative \%

Ruakok_Unit12abov_10.\$1 $\begin{array}{lllllllllllllllllllllllll}-1.75 & -1.25 & -0.75 & -0.25 & 0.25 & 0.75 & 1.25 & 1.75 & 2.25 & 2.75 & 3.25 & 3.75 & 4.25 & 4.75 & 5.25 & 5.75 & 6.25 & 6.75 & 7.25 & 7.75 & 8.25 & 8.75 & 9.25 & 9.75 & 10\end{array}$

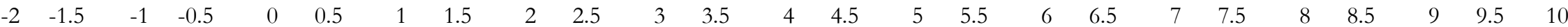

Ms

$\begin{array}{lllllllllllllllllllllllllll}0 & 0 & 0 & 0 & 0 & 0 & \# \# \# & 1.013 & 6.328 & 6.77 & 6.937 & 9.299 & 9.931 & 10.86 & 7.68 & 8.153 & 8.063 & 6.227 & 5.228 & 4.634 & 4.453 & 3.437 & 0.971 & 0.01 & 0\end{array}$ $\begin{array}{lllllllllllllllllllllllll}0 & 0 & 0 & 0 & 0 & 0 & \# \# \# & 1.014 & 7.342 & 14.11 & 21.05 & 30.35 & 40.28 & 51.14 & 58.82 & 66.98 & 75.04 & 81.27 & 86.49 & 91.13 & 95.58 & 99.02 & 99.99 & 100 & 100\end{array}$ Mean: Median: Mode: S.D.

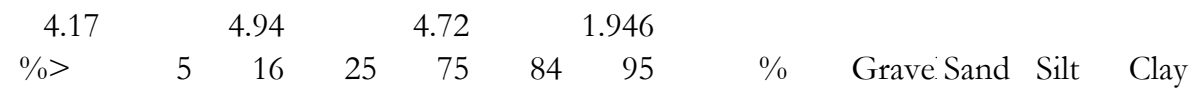

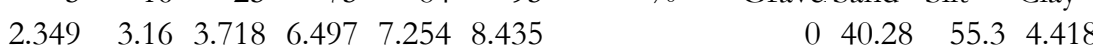

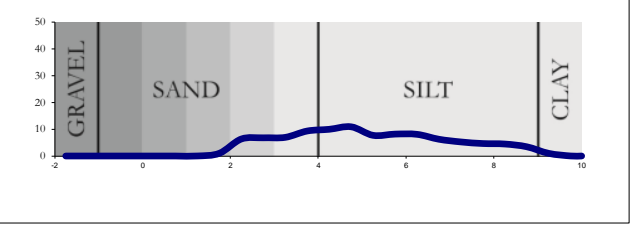

Ms

$\begin{array}{lllllllllllllllllllllllllll}0 & 0 & 0 & 0 & 0 & 0 & 0.001 & 0.998 & 5.267 & 6.237 & 6.944 & 8.341 & 10.53 & 10.53 & 8.013 & 7.869 & 7.618 & 6.046 & 5.068 & 4.804 & 4.715 & 4.011 & 2.309 & 0.672 & 0.036\end{array}$ $\begin{array}{llllllllllllllllllllllllll}0 & 0 & 0 & 0 & 0 & 0 & 0.001 & 0.999 & 6.266 & 12.5 & 19.45 & 27.79 & 38.31 & 48.84 & 56.85 & 64.72 & 72.34 & 78.39 & 83.45 & 88.26 & 92.97 & 96.98 & 99.29 & 99.96 & 100\end{array}$ Mean: Median: Mode: S.D.

$\begin{array}{llll}4.27 & 5.06 & 4.58 & 2.034\end{array}$

$\begin{array}{lllllll}\% & 5 & 16 & 25 & 75 & 84 & 95\end{array}$ $2.397 \quad 3.2593 .849 \quad 6.706 \quad 7.556 \quad 8.734$

$\% \quad$ Grave Sand Silt Clay $038.3154 .66 \quad 7.028$

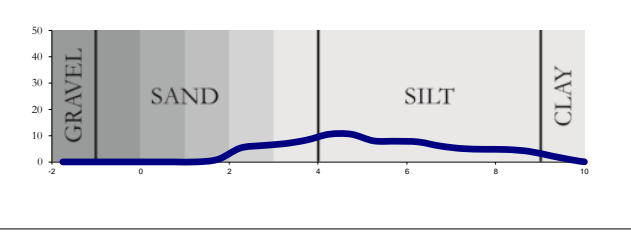

Ms

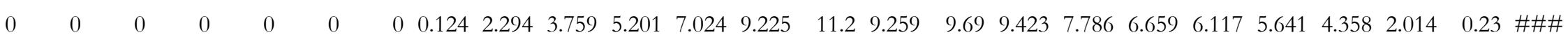
$\begin{array}{lllllllllllllllllllllllll}0 & 0 & 0 & 0 & 0 & 0 & 0 & 0.124 & 2.418 & 6.176 & 11.38 & 18.4 & 27.63 & 38.82 & 48.08 & 57.77 & 67.19 & 74.98 & 81.64 & 87.76 & 93.4 & 97.76 & 99.77 & 100 & 100\end{array}$ Mean: Median: Mode: S.D. $\begin{array}{lrrr}4.74 & 5.61 & 4.72 & 1.844\end{array}$

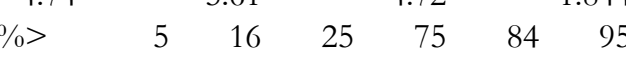
$2.843 \quad 3.8384 .377 \quad 7.002 \quad 7.6898 .66$

$\% \quad$ Grave Sand Silt Clay $027.63 \quad 65.77 \quad 6.602$

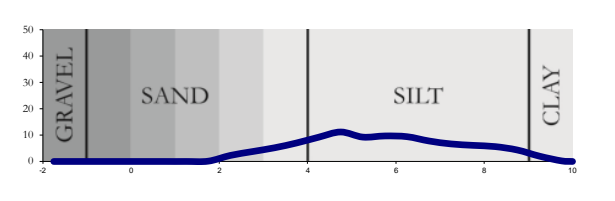

Ms

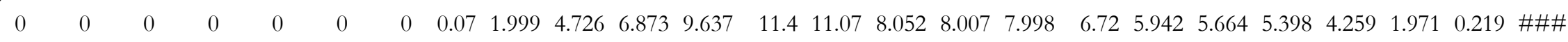
$\begin{array}{llllllllllllllllllllllllll}0 & 0 & 0 & 0 & 0 & 0 & 0 & 0.07 & 2.068 & 6.794 & 13.67 & 23.3 & 34.7 & 45.77 & 53.82 & 61.83 & 69.83 & 76.55 & 82.49 & 88.15 & 93.55 & 97.81 & 99.78 & 100 & 100\end{array}$ Mean: Median: Mode: S.D.

$\begin{array}{crrrrrr}\begin{array}{crrrr}\text { M.58 } \\ \%>\end{array} & & 5.24 & & 4.45 & & 1.881 \\ \% & 5 & 16 & 25 & 75 & 84 & 95\end{array}$ $\begin{array}{lllllll}2.829 & 3.634 & 4.077 & 6.878 & 7.632 & 8.649\end{array}$
$\% \quad$ Grave Sand Silt Clay $\begin{array}{llll}0 & 34.7 & 58.85 & 6.448\end{array}$

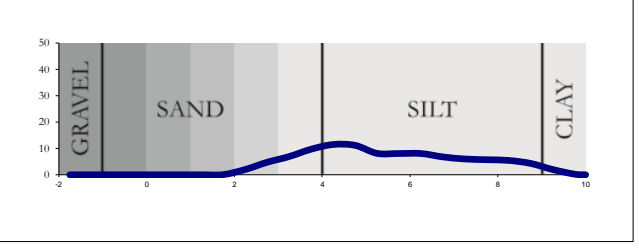


Ruakokopatuna Bridge Section

Class midpoints

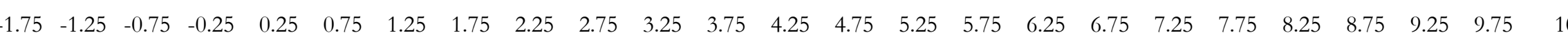

Class limits

$\begin{array}{lllllllllllllllllllllllll}-2 & -1.5 & -1 & -0.5 & 0 & 0.5 & 1 & 1.5 & 2 & 2.5 & 3 & 3.5 & 4 & 4.5 & 5 & 5.5 & 6 & 6.5 & 7 & 7.5 & 8 & 8.5 & 9 & 9.5 & 10\end{array}$

RK 13 Top

Frequency $\%$

Cumulative \%

Ruakok_Unit12abov_11.\$1s

Ms

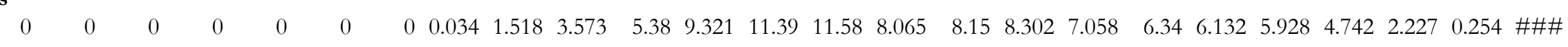
$\begin{array}{lllllllllllllllllllllllllll}0 & 0 & 0 & 0 & 0 & 0 & 0 & 0.034 & 1.553 & 5.125 & 10.51 & 19.83 & 31.22 & 42.8 & 50.87 & 59.02 & 67.32 & 74.38 & 80.72 & 86.85 & 92.78 & 97.52 & 99.75 & 100 & 100\end{array}$ Mean: Median: Mode: S.D.

$\begin{array}{lrrr}4.73 & 5.44 & 4.58 & 1.857\end{array}$

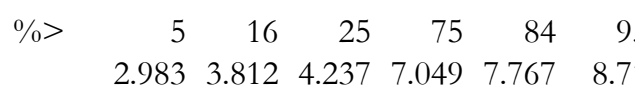

$\% \quad$ Grave Sand Silt Clay $031.2261 .56 \quad 7.224$

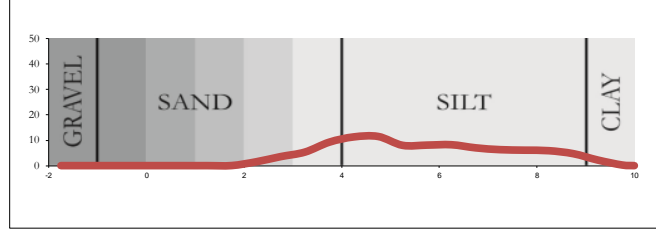

RK 13 Top

Frequency $\%$

Cumulative \%

Ms

Ruakok_Unit12abov_12.\$1s

$\begin{array}{llllllllllllllllllllllllllllllll}0 & 0 & 0 & 0 & 0 & 0 & 0 & 0.132 & 4.084 & 9.958 & 13.63 & 15.15 & 13.74 & 10.54 & 5.898 & 5.574 & 5.055 & 3.789 & 3.154 & 2.964 & 2.816 & 2.241 & 1.105 & 0.175 & \# \# \# \\ 0 & 0 & 0 & 0 & 0 & 0 & & 0 & 0.132 & 4.216 & 14.17 & 27.8 & 42.95 & 56.69 & 67.23 & 73.13 & 78.7 & 83.76 & 87.55 & 90.7 & 93.66 & 96.48 & 98.72 & 99.82 & 100 & 1000\end{array}$ $\begin{array}{lllllllllllllllllllllllll}0 & 0 & 0 & 0 & 0 & 0 & 0 & 0.132 & 4.216 & 14.17 & 27.8 & 42.95 & 56.69 & 67.23 & 73.13 & 78.7 & 83.76 & 87.55 & 90.7 & 93.66 & 96.48 & 98.72 & 99.82 & 100 & 100\end{array}$ Mean: Median: Mode: S.D.

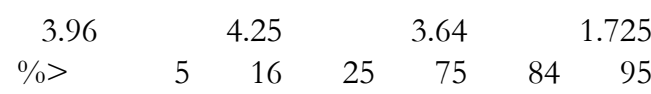

$\begin{array}{llllll}2.544 & 3.076 & 3.407 & 5.675 & 6.528 & 8.234\end{array}$

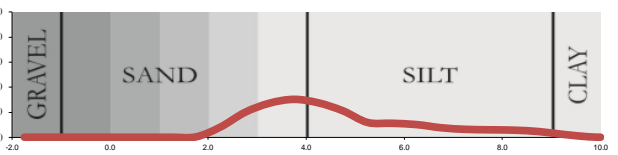

RK 13 Centre

Frequency \%

Ms

Cumulative $\%$

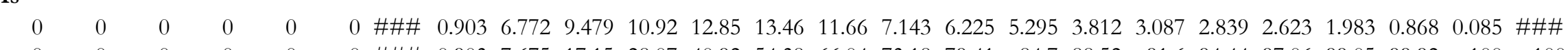

RuaK BRB12lam 17.\$1

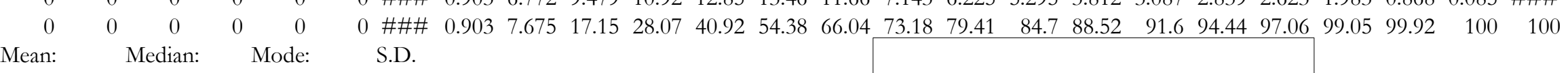
$\begin{array}{rrrr}3.89 & 4.34 & 4.32 & 1.743\end{array}$

$\%>\quad \begin{array}{lllllllll}5 & 16 & 25 & 75 & 84 & 95 & \% & \text { Grave Sand Silt } \quad \text { Clay }\end{array}$ $\begin{array}{lllllllll}2.346 & 2.94 & 3.371 & 5.647 & 6.422 & 8.104 & 54.38 & 42.69 & 2.935\end{array}$

RK 13 Centre

Frequency $\%$

Cumulative \%

RuaK_BRB12lam_18.\$1s
Ms

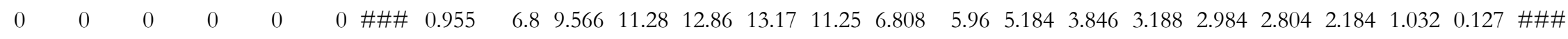
$\begin{array}{llllllllllllllllllllllllll}0 & 0 & 0 & 0 & 0 & 0 & \# \# \# & 0.955 & 7.755 & 17.32 & 28.6 & 41.46 & 54.63 & 65.88 & 72.69 & 78.65 & 83.83 & 87.68 & 90.87 & 93.85 & 96.66 & 98.84 & 99.87 & 100 & 100\end{array}$ Mean: Median: Mode: S.D.

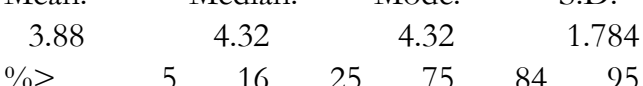
$2.342 .933 \quad 3.352 \quad 5.696 \quad 6.519-8.2$
$\% \quad$ Grave Sand Silt Clay 0
$54.63 \quad 42.03 \quad 3.344$
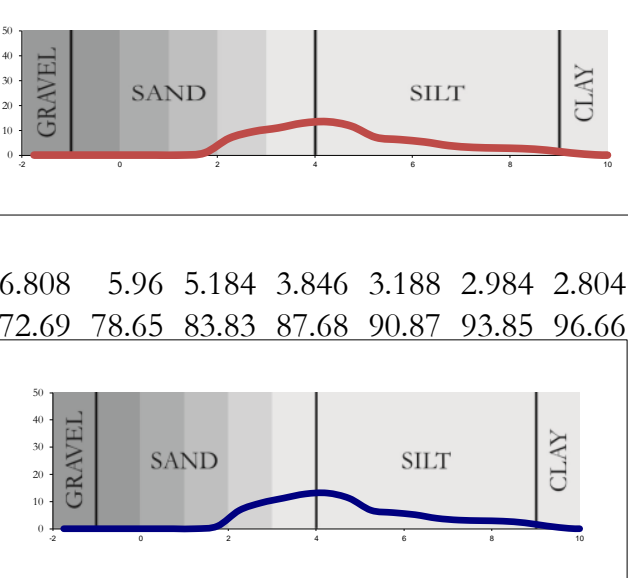
RK 13 Centre

Frequency $\%$

Cumulative \%

Ruakok_Unit12lami_05.\$1s

Ms

$\begin{array}{llllllllllllllllllllllllll}0 & 0 & 0 & 0 & 0 & 0 & 0 & 0.358 & 4.422 & 7.82 & 8.998 & 12.15 & 14 & 13.01 & 9.055 & 7.948 & 6.53 & 4.387 & 3.257 & 2.825 & 2.585 & 1.914 & 0.716 & 0.032 & 0\end{array}$ $\begin{array}{llllllllllllllllllllllllllll}0 & 0 & 0 & 0 & 0 & 0 & 0 & 0.358 & 4.78 & 12.6 & 21.6 & 33.75 & 47.75 & 60.75 & 69.81 & 77.76 & 84.28 & 88.67 & 91.93 & 94.75 & 97.34 & 99.25 & 99.97 & 100 & 100\end{array}$ Mean: Median: Mode: S.D.

$\begin{array}{llll}4.11 & 4.58 & 4.45 & 1.655\end{array}$

$\%>\quad \begin{array}{llllll}5 & 16 & 25 & 75 & 84 & 95\end{array}$ $\begin{array}{llllll}2.514 & 3.205 & 3.654 & 5.825 & 6.473 & 8.048\end{array}$

$\% \quad$ Grave Sand Silt Clay

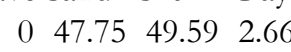

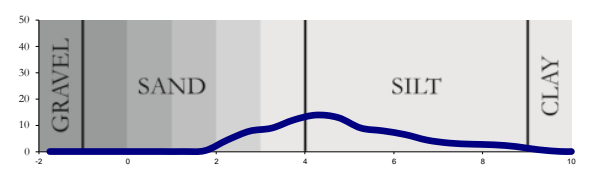

Ms

Frequency \%

Cumulative \%

Ruakok_Unit12lami_06.\$1s

$\begin{array}{lllllllllllllllllllllllllll}0 & 0 & 0 & 0 & 0 & 0 & 0 & 0.386 & 5.325 & 9.555 & 8.877 & 9.291 & 9.784 & 7.497 & 4.588 & 4.673 & 6.299 & 6.401 & 6.299 & 6.392 & 6.733 & 5.619 & 2.186 & 0.094 & 0\end{array}$ $\begin{array}{llllllllllllllllllllllllll}0 & 0 & 0 & 0 & 0 & 0 & 0 & 0.386 & 5.712 & 15.27 & 24.14 & 33.43 & 43.22 & 50.72 & 55.3 & 59.98 & 66.28 & 72.68 & 78.98 & 85.37 & 92.1 & 97.72 & 99.91 & 100 & 100\end{array}$

Mean: Median: Mode: $\quad$ S.D.

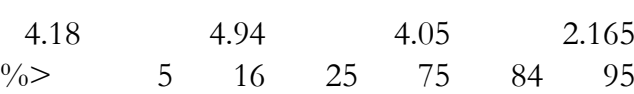

$2.454 \quad 3.04 \quad 3.551 \quad 7.185 \quad 7.896 \quad 8.731$

$\% \quad$ Grave Sand Silt Clay

$0 \quad 43.22 \quad 48.88 \quad 7.899$

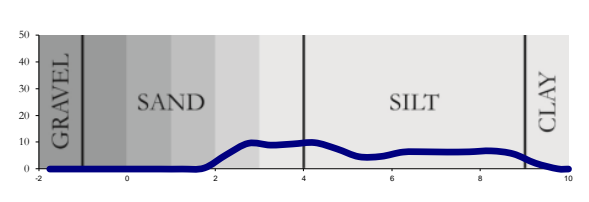

RK 13 Lower

Ms

Frequency \%

Cumulative \%

RuaK_BRB12_15.\$1s

0

0

0 \#\#\#

20

(2)

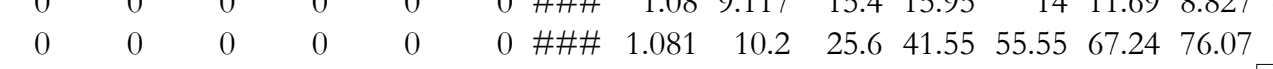

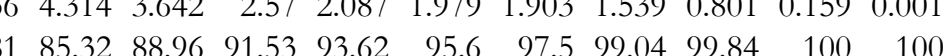
Mean: Median: Mode: S.D.

$\begin{array}{rrrrrrr}3.56 & & 3.79 & & 3.1 & & 1.632 \\ \%> & 5 & 16 & 25 & 75 & 84 & 95\end{array}$

$\begin{array}{llllll}2.278 & 2.696 & 2.981 & 4.921 & 5.848 & 7.849\end{array}$

$\% \quad$ Grave Sand Silt Clay

$\begin{array}{llll}0 & 67.24 & 30.26 & 2.5\end{array}$

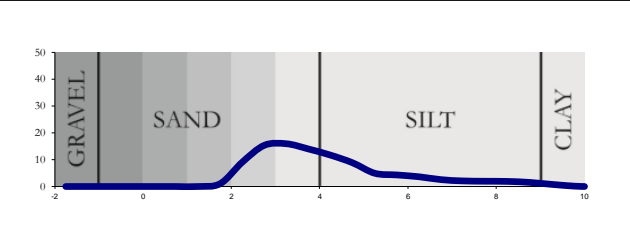

RK 13 Lower

Frequency \%

Cumulative \%

RuaK_BRB12_16.\$1s
Ms

$\begin{array}{llllllllllllllllllllllllllllll}0 & 0 & 0 & 0 & 0 & 0 & \# \# \# & 1.043 & 8.716 & 13.81 & 13.64 & 12.23 & 10.54 & 8.54 & 5.032 & 4.738 & 4.281 & 3.182 & 2.769 & 2.851 & 2.994 & 2.733 & 1.826 & 0.822 & 0.248\end{array}$ $\begin{array}{lllllllllllllllllllllllll}0 & 0 & 0 & 0 & \# \# \# & 1.044 & 9.76 & 23.57 & 37.21 & 49.44 & 59.98 & 68.52 & 73.56 & 78.29 & 82.57 & 85.76 & 88.53 & 91.38 & 94.37 & 97.1 & 98.93 & 99.75 & 100\end{array}$ Mean: Median: Mode: S.D.

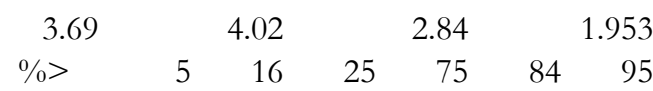
$\begin{array}{llllll}2.287 & 2.729 & 3.052 & 5.66 & 6.709 & 8.608\end{array}$
$\% \quad$ Grave Sand Silt Clay

$\begin{array}{llll}0 & 59.98 & 34.39 & 5.629\end{array}$

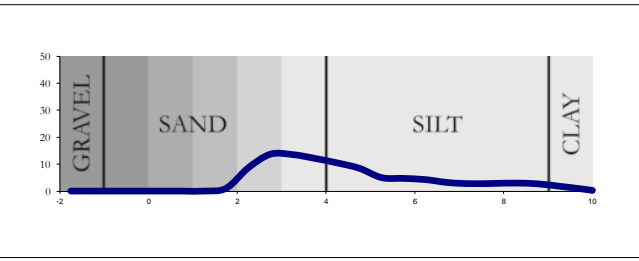


Ruakokopatuna Bridge Section

Class midpoints

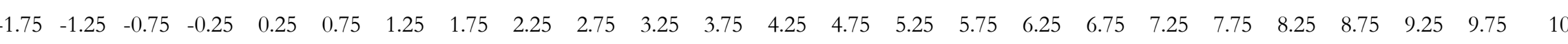

Class limits

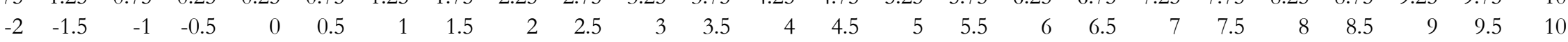

RK 10

Frequency \%

Cumulative \%

Ruakok_Unit9-top_16.\$1

\section{Sw}

$\begin{array}{lllllllllllllllllllllllll}0 & 0 & 0 & 0 & 0 & 0 & 0 & 2.239 & 28.95 & 42.05 & 17.69 & 4.542 & 1.141 & 0.777 & 0.341 & 0.436 & 0.455 & 0.354 & 0.329 & 0.306 & 0.25 & 0.132 & 0.014 & 0 & 0\end{array}$ $\begin{array}{llllllllllllllllllllllllll}0 & 0 & 0 & 0 & 0 & 0 & 0 & 2.239 & 31.19 & 73.24 & 90.92 & 95.46 & 96.6 & 97.38 & 97.72 & 98.16 & 98.61 & 98.97 & 99.3 & 99.6 & 99.85 & 99.99 & 100 & 100 & 100\end{array}$ Mean: Median: Mode: S.D.

$\begin{array}{llll}2.71 & 2.71 & 2.7 & 0.503\end{array}$

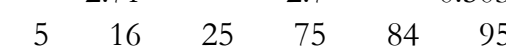

$\begin{array}{llllll}2.101 & 2.302 & 2.423 & 3.027 & 3.216 & 3.911\end{array}$

$\% \quad$ Grave Sand Silt Clay

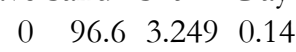

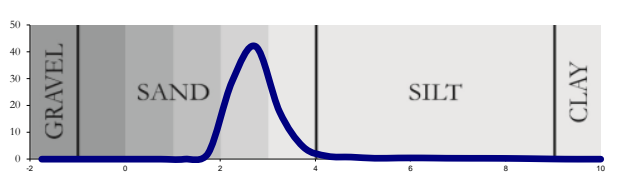

Sw

Frequency $\%$

Cumulative \%

Ruakok_Unit9-top_17.\$1s

$\begin{array}{llllllllllllllllllllllllllll}0 & 0 & 0 & 0 & 0 & 0 & 0 & 2.069 & 28.85 & 42.48 & 17.75 & 4.459 & 1.066 & 0.743 & 0.306 & 0.417 & 0.446 & 0.351 & 0.328 & 0.309 & 0.261 & 0.148 & 0.021 & 0 & 0\end{array}$ $\begin{array}{llllllllllllllllllllllllll}0 & 0 & 0 & 0 & 0 & 0 & 0 & 2.069 & 30.92 & 73.4 & 91.15 & 95.6 & 96.67 & 97.41 & 97.72 & 98.14 & 98.58 & 98.93 & 99.26 & 99.57 & 99.83 & 99.98 & 100 & 100 & 100\end{array}$ Mean: Median: Mode: S.D.

$\begin{array}{llrr}2.71 & 2.71 & 2.7 & 0.495\end{array}$

$\%>\quad \begin{array}{rrrrrr}0 & 16 & 25 & 75 & 84 & 95\end{array}$

$\begin{array}{llllll}2.107 & 2.308 & 2.427 & 3.024 & 3.21 & 3.882\end{array}$

$\% \quad$ Grave Sand Silt Clay $0 \quad 96.67 \quad 3.161 \quad 0.169$

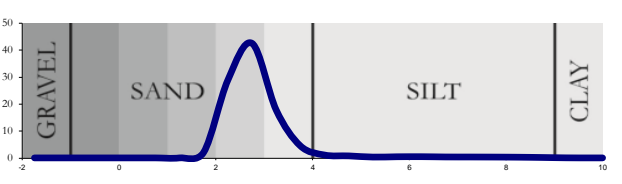

RK 9 Top

Frequency \%

Cumulative \%

Ruakok_Unit9-1mup_13.\$1s
Sd

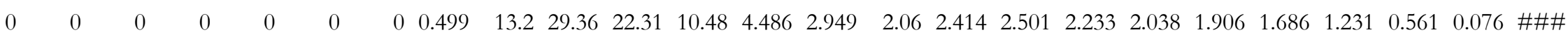
Mean: Median: Mode: S.D. $\begin{array}{rrrrrrr}3.2 & & 3.13 & & 2.84 & & 1.465 \\ \%> & 5 & 16 & 25 & 75 & 84 & 95\end{array}$ $\begin{array}{llllll}2.278 & 2.541 & 2.698 & 3.937 & 5.164 & 7.618\end{array}$ $\begin{array}{lllllll}8.949 & 2.06 & 2.414 & 2.501 & 2.233 & 2.1\end{array}$ 465
$\% \quad$ Grave Sand Silt Clay $\begin{array}{llll}0 & 80.34 & 17.79 & 1.869\end{array}$

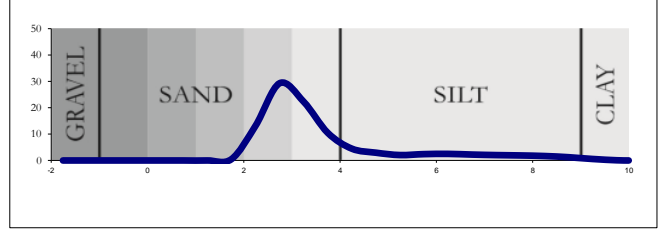

Sd

RK 9 Top

Cumulative \%

Ruakok_Unit9-1mup_14.\$1s

$\begin{array}{lllllllllllllllllllllllll}0 & 0 & 0 & 0 & 0 & 0 & 0 & 0.176 & 15.32 & 32.56 & 24.52 & 12.08 & 4.305 & 2.287 & 0.976 & 1.454 & 1.352 & 1.146 & 1.066 & 0.953 & 0.948 & 0.711 & 0.144 & 0 & 0\end{array}$

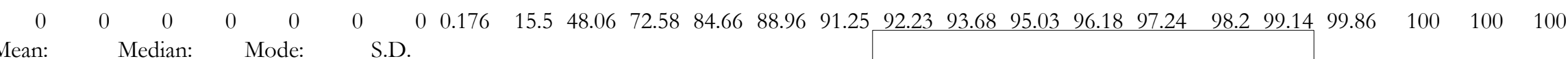
Median: $\quad$ S.D.

$\begin{array}{lrrrrrr}3.07 & 3.03 & & 2.84 & 0.999 & & \\ \% & 5 & 16 & 25 & 75 & 84 & 95\end{array} \quad \% \quad$ Grave Sand Silt Clay $\begin{array}{llllllllll}2.279 & 2.508 & 2.652 & 3.57 & 3.952 & 6.486 & 0 & 88.96 & 10.18 & 0.856\end{array}$

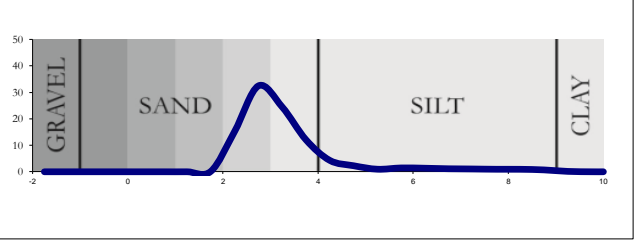


Ruakokopatuna Bridge Section

Class midpoint

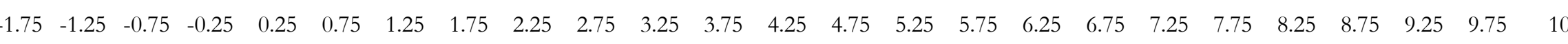

Class limits

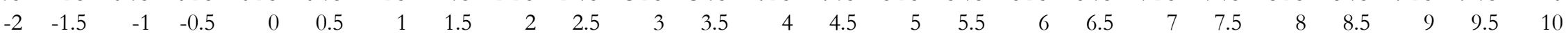

RK 9 Top

Frequency \%

Cumulative \%

Ruakok_Unit9-1mup_15.\$1s

Sd

$\begin{array}{lllllllllllllllllllllllllllll}0 & 0 & 0 & 0 & 0 & 0 & 0 & 0.305 & 16.05 & 32.49 & 23.73 & 12.03 & 4.225 & 2.3 & 1.014 & 1.528 & 1.321 & 1.106 & 1.042 & 0.955 & 0.963 & 0.753 & 0.192 & \# \# \# & 0\end{array}$ $\begin{array}{llllllllllllllllllllllllllll}0 & 0 & 0 & 0 & 0 & 0 & 0 & 0.305 & 16.35 & 48.84 & 72.57 & 84.6 & 88.83 & 91.13 & 92.14 & 93.67 & 94.99 & 96.09 & 97.14 & 98.09 & 99.06 & 99.81 & 100 & 100 & 100\end{array}$ Mean: Median: Mode: S.D.

$\begin{array}{llll}3.06 & 3.02 & 2.84 & 1.008\end{array}$

$\begin{array}{lllllll}\% & 5 & 16 & 25 & 75 & 84 & 95\end{array}$ $\begin{array}{llllll}2.257 & 2.493 & 2.641 & 3.568 & 3.952 & 6.504\end{array}$

$\% \quad$ Grave Sand Silt Clay $\begin{array}{llll}0 & 88.83 & 10.23 & 0.945\end{array}$

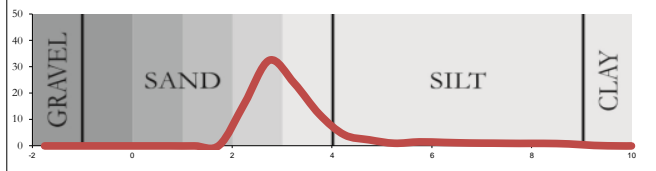

\section{RK 9 Lower}

Frequency $\%$

Cumulative \%

RuaK Bed10wK\&C_11.\$1s

Frequency $\%$

Cumulative \%

RuaK_Bed10wK\&C 12.\$1s

\section{Sd}

(

Tean:

Mean:
2.31

$\%>$

$\begin{array}{rrrrrr}-5 & 16 & 25 & 75 & 84 & 95\end{array}$

$\begin{array}{llllll}0.714 & 1.627 & 2.095 & 3.479 & 3.835 & 5.14\end{array}$

Sd

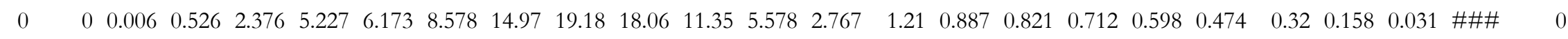
$\begin{array}{lllllllllllllllllllllllll}0 & 0 & 0.006 & 0.532 & 2.909 & 8.136 & 14.31 & 22.89 & 37.85 & 57.04 & 75.1 & 86.44 & 92.02 & 94.79 & 96 & 96.89 & 97.71 & 98.42 & 99.02 & 99.49 & 99.81 & 99.97 & 100 & 100 & 100\end{array}$ Mean: Median: Mode: S.D.

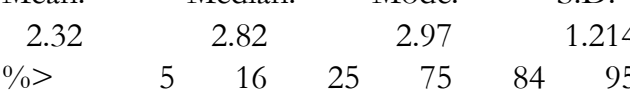
$0.732 \quad 1.6252 .088 \quad 3.497 \quad 3.858 \quad 5.062$
$\% \quad$ Grave Sand Silt Clay $0.00692 .02 \quad 7.788 \quad 0.19$

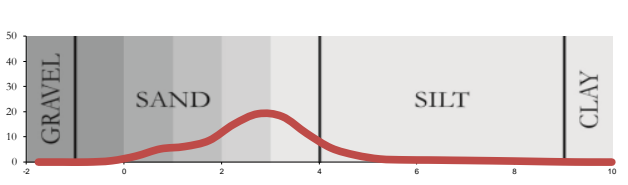

\section{RK 8}

Frequency $\%$

Cumulative $\%$

Ruakok_Unit8crse_25.\$1s
SBt

$\begin{array}{llllllllllllllllllllllllll}0 & 2.133 & 4.248 & 7.022 & 11.02 & 13.39 & 14.76 & 15.26 & 11.73 & 7.534 & 4.578 & 2.857 & 1.676 & 0.773 & 0.562 & 0.538 & 0.488 & 0.433 & 0.376 & 0.298 & 0.201 & 0.097 & 0.024 & \# \# \#\end{array}$ $\begin{array}{lllllllllllllllllllllllll}0 & 2.133 & 6.381 & 13.4 & 24.42 & 37.81 & 52.57 & 67.83 & 79.56 & 87.1 & 91.68 & 94.53 & 96.21 & 96.98 & 97.54 & 98.08 & 98.57 & 99 & 99.38 & 99.68 & 99.88 & 99.98 & 100 & 100\end{array}$ Mean: Median: Mode: S.D.

$\begin{array}{rrrrrrr}1.39 & & 1.91 & & 2.16 & & 1.39 \\ \%> & 5 & 16 & 25 & 75 & 84 & 95\end{array}$

$\begin{array}{lllllll}-0.2 & 0.611 & 1.004 & 2.774 & 3.258 & 4.602\end{array}$

$\% \quad$ Grave Sand Silt Clay $2.133 \quad 92.4 \quad 5.144 \quad 0.323$

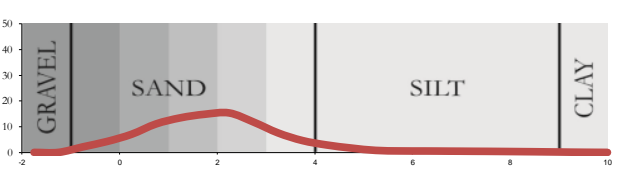


RK 8

Frequency $\%$

Cumulative \%

Ruakok_Unit8crse_26.\$1s
SBt

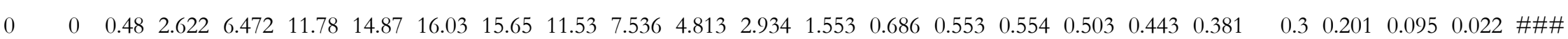

$\begin{array}{lllllllllllllllllllllllll}0 & 0 & 0.48 & 3.102 & 9.574 & 21.35 & 36.23 & 52.25 & 67.9 & 79.43 & 86.96 & 91.77 & 94.71 & 96.26 & 96.95 & 97.5 & 98.05 & 98.56 & 99 & 99.38 & 99.68 & 99.88 & 99.98 & 100 & 100\end{array}$

Mean: Median: Mode: S.D.

$\begin{array}{cccc}M & & & \\ 1.57 & 1.93 & 2.03 & 1.284\end{array}$

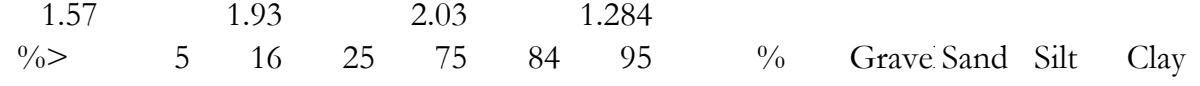

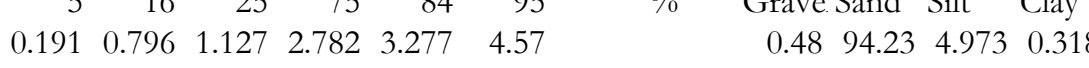

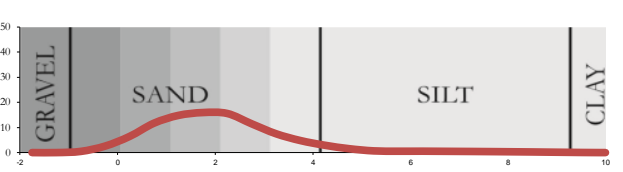

\section{RK 7}

Frequency $\%$

Cumulative \%

RuaK_Bed8wK\&C_09.\$1

\section{$\mathrm{Sp}$}

$\begin{array}{ll}0 & 0 \\ 0 & 0\end{array}$

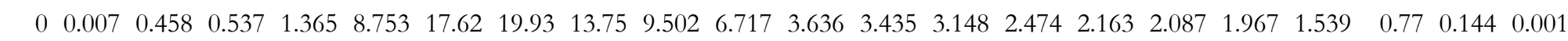
Mean: Median: Mode: S.D.

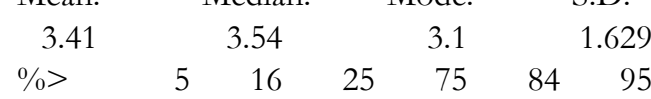

$\begin{array}{llllll}2.214 & 2.662 & 2.91 & 4.697 & 5.758 & 7.861\end{array}$

$\% \quad$ Grave Sand Silt Clay $\begin{array}{llll}0 & 71.92 & 25.63 \quad 2.45\end{array}$

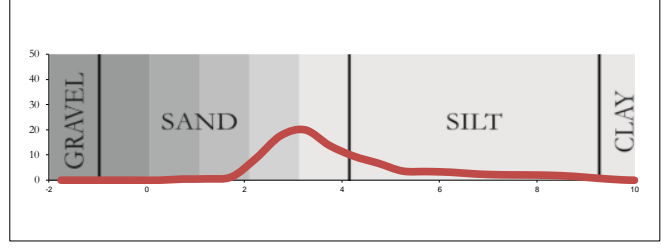

RK 7

Frequency \%

Cumulative $\%$

RuaK_Bed8wK\&C 10.\$1
$\mathrm{Sp}$

$0 \quad 0 \quad 0$

$\begin{array}{lll}0 & 0 & 0\end{array}$

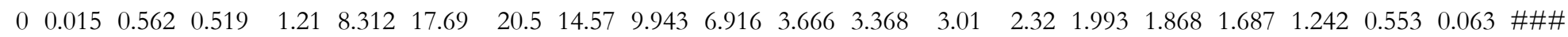
$\begin{array}{lllllllllllllllllllllll}0 & 0.015 & 0.577 & 1.096 & 2.305 & 10.62 & 28.3 & 48.8 & 63.37 & 73.31 & 80.23 & 83.9 & 87.26 & 90.27 & 92.59 & 94.59 & 96.45 & 98.14 & 99.38 & 99.94 & 100 & 100\end{array}$ Mean: Median: Mode: S.D.

$\begin{array}{lrrrrrllll}3.39 & 3.53 & & 3.1 & 1.524 & & & \\ \%> & 5 & 16 & 25 & 75 & 84 & 95 & \% & \text { Grave Sand Silt } & \text { Clay }\end{array}$

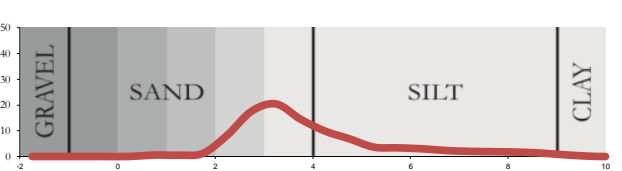

RK 5

Frequency \%

Cumulative \%

Ruakok_Unit5-30ab_23.\$1s

\section{Sw}

$\begin{array}{lllllllllllllllllllllllll}0 & 0 & 3.774 & 6.528 & 9.35 & 12 & 9.724 & 8.38 & 12.58 & 15.28 & 10.87 & 4.001 & 1.335 & 0.98 & 0.696 & 0.739 & 0.778 & 0.741 & 0.683 & 0.605 & 0.482 & 0.317 & 0.138 & 0.022 & \# \# \#\end{array}$ $\begin{array}{lllllllllllllllllllllllll}0 & 0 & 3.774 & 10.3 & 19.65 & 31.65 & 41.37 & 49.75 & 62.33 & 77.62 & 88.48 & 92.48 & 93.82 & 94.8 & 95.49 & 96.23 & 97.01 & 97.75 & 98.44 & 99.04 & 99.52 & 99.84 & 99.98 & 100 & 100\end{array}$ Mean: Median: Mode: S.D.

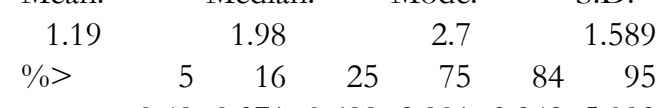

$\begin{array}{rrrrrrr}-0.49 & 0.271 & 0.689 & 2.901 & 3.242 & 5.092\end{array}$

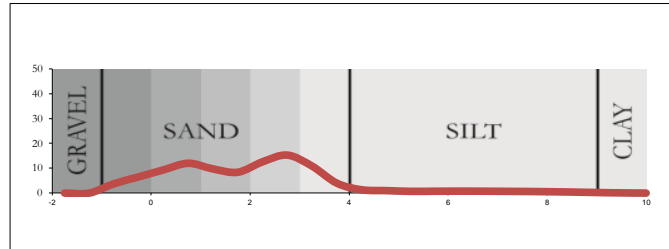


Ruakokopatuna Bridge Section

Class midpoints

Class limits

RK 5

Frequency $\%$

Cumulative \%

Ruakok_Unit5-30ab_24.\$1s $\begin{array}{lllllllllllllllllllllllll}-1.75 & -1.25 & -0.75 & -0.25 & 0.25 & 0.75 & 1.25 & 1.75 & 2.25 & 2.75 & 3.25 & 3.75 & 4.25 & 4.75 & 5.25 & 5.75 & 6.25 & 6.75 & 7.25 & 7.75 & 8.25 & 8.75 & 9.25 & 9.75 & 10\end{array}$

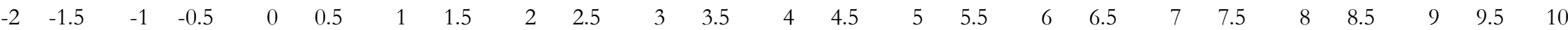

Sw

$\begin{array}{lllllllllllllllllllllll}0 & 2.529 & 5.261 & 8.223 & 10.95 & 9.388 & 8.532 & 13.33 & 16.8 & 12.15 & 4.52 & 1.494 & 1.128 & 0.839 & 0.876 & 0.89 & 0.82 & 0.732 & 0.628 & 0.481 & 0.3 & 0.117 & 0.012\end{array} \# \# \#$

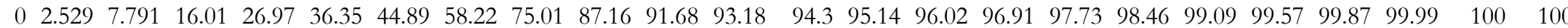

Mean: Median: Mode: S.D.

$\begin{array}{rrrr}1.38 & 2.21 & 2.7 & 1.576\end{array}$

$\begin{array}{lrrrrrr}1.38 & & 2.21 & & 2.7 & & 1.576 \\ \%> & 5 & 16 & 25 & 75 & 84 & 95\end{array}$

$\begin{array}{rrrrrr}5 & 16 & 25 & 75 & 84 & 95 \\ -0.3 & 0.471 & 0.89 & 2.994 & 3.325 & 5.392\end{array}$

$\% \quad$ Grave Sand Silt Clay $\begin{array}{llll}2.529 & 90.65 & 6.395 & 0.429\end{array}$

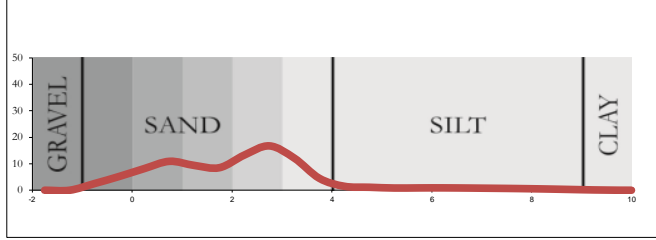

Frequency $\%$

Cumulative \%

RuaK_Bed5wK\&C 07.\$1 $\begin{array}{lllllllllllllllllllllllll}0 & 0 & 0.055 & 2.793 & 5.546 & 11.77 & 18.94 & 26.91 & 44.1 & 68.14 & 86.77 & 92.94 & 94.28 & 95.28 & 95.77 & 96.61 & 97.42 & 98.09 & 98.74 & 99.31 & 99.77 & 99.99 & 100 & 100 & 100\end{array}$

Mean: Median: Mode: S.D.

$\begin{array}{rrrrrrr}2.03 & & 2.64 & & 2.84 & & 1.21 \\ \%> & 5 & 16 & 25 & 75 & 84 & 95\end{array}$

$\begin{array}{llllll}0.373 & 1.235 & 1.925 & 3.145 & 3.393 & 4.802\end{array}$

$\% \quad$ Grave Sand Silt Clay $\begin{array}{llll}0.055 & 94.23 & 5.485 & 0.233\end{array}$

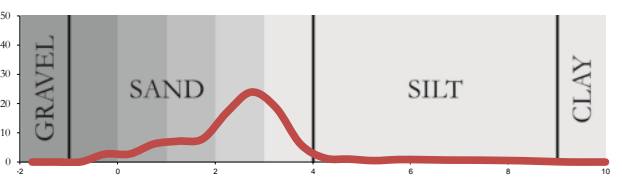

Frequency $\%$

Cumulative \%

RuaK_Bed5wK\&C_08.\$1s

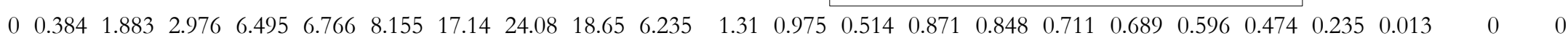
Mean: Median: Mode: S.D.

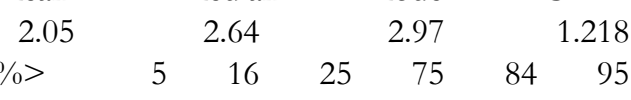

$\begin{array}{lllllll}0.456 & 1.256 & 1.936 & 3.149 & 3.4 & 4.958\end{array}$

$\% \quad$ Grave Sand Silt Clay

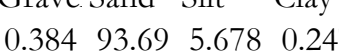

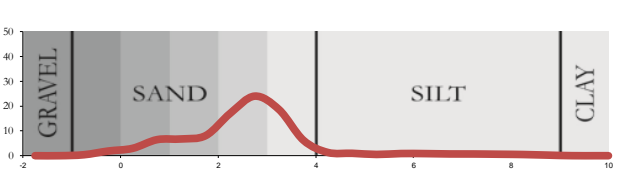

\section{RK 3}

Frequency $\%$

Cumulative \%

Ruakok_Unit3-80cm $20 . \$ 1$
Sw

0

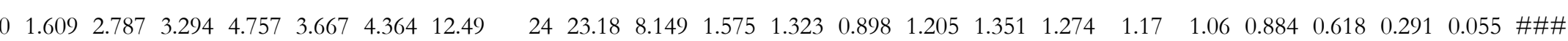

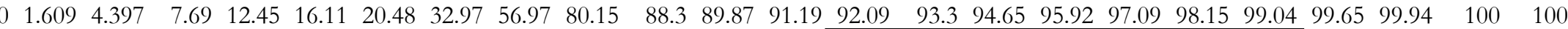
Mode: S.D.

$\%>\quad \begin{array}{rrrrrr}0 & 16 & 25 & 75 & 84 & 95\end{array}$ $\begin{array}{llllll}0.024 & 1.404 & 2.22 & 3.356 & 3.643 & 6.624\end{array}$
$\% \quad$ Grave Sand Silt Clay $1.609 \quad 88.26 \quad 9.165 \quad 0.964$

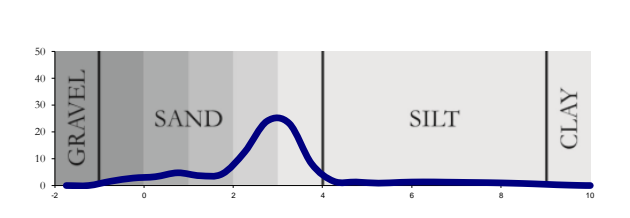


Ruakokopatuna Bridge Section

Class midpoints

Class limits

RK 3

Frequency $\%$

Cumulative \%

Ruakok_Unit3-80cm_21.\$1s

\section{RK 3}

Frequency \%

Cumulative \%

Ruakok_Unit3-80cm_22\$1

Tean:

Mean:
2.04

$\%>$

$\begin{array}{lrrrrr}5 & 16 & 25 & 75 & 8.97 & 1.518\end{array}$

$\begin{array}{llllll}0.04 & 1.633 & 2.264 & 3.369 & 3.663 & 6.63\end{array}$

$\% \quad$ Grave Sand Silt Clay $\begin{array}{llll}1.899 & 87.67 & 9.549 & 0.88\end{array}$
Grave Sand Silt Clay $\begin{array}{llll}0.361 & 90.86 \quad 8.091 & 0.687\end{array}$
Mean: Median: Mode: S.D.

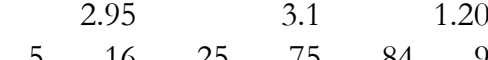

$\begin{array}{llllll}0.813 & 2.096 & 2.418 & 3.367 & 3.616 & 6.288\end{array}$

Median: Mode: S.D.

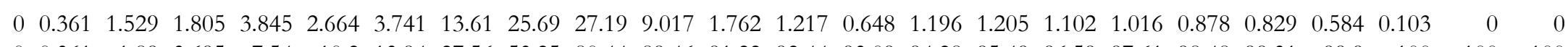
$\begin{array}{lllllllllllllllllllllllll}0 & 0.361 & 1.89 & 3.695 & 7.54 & 10.2 & 13.94 & 27.56 & 53.25 & 80.44 & 89.46 & 91.22 & 92.44 & 93.09 & 94.28 & 95.49 & 96.59 & 97.61 & 98.48 & 99.31 & 99.9 & 100 & 100 & 100\end{array}$

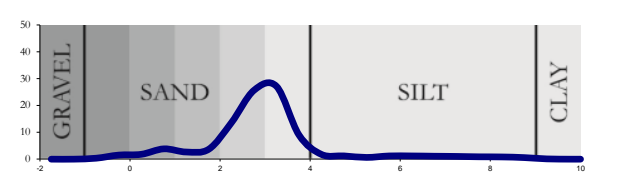

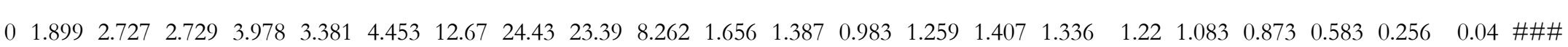

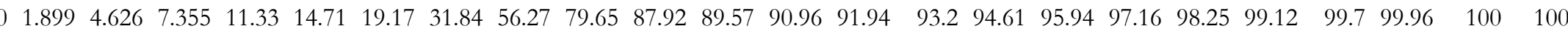

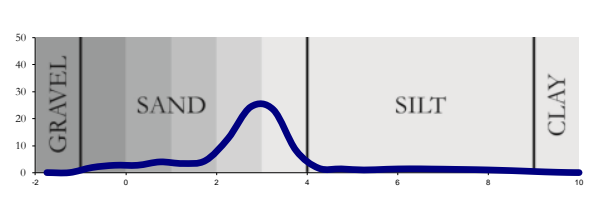

Sw

Frequency $\%$

Cumulative \%

RuaK_Bed3wK\&C 05.\$1s

$\begin{array}{llllllllllllllllllllllll}0 & 0.178 & 1.323 & 1.847 & 4.258 & 4.032 & 4.656 & 11.33 & 20.91 & 21.83 & 9.492 & 3.098 & 2.663 & 1.904 & 2.274 & 2.246 & 1.915 & 1.681 & 1.528 & 1.329 & 0.971 & 0.459 & 0.078 & \# \# \#\end{array}$ $\begin{array}{llllllllllllllllllllllll}0 & 0.178 & 1.501 & 3.347 & 7.605 & 11.64 & 16.29 & 27.63 & 48.53 & 70.36 & 79.85 & 82.95 & 85.61 & 87.52 & 89.79 & 92.04 & 93.95 & 95.63 & 97.16 & 98.49 & 99.46 & 99.92 & 100 & 100\end{array}$ Mean: Median: Mode: S.D.

$\begin{array}{rrrrrrr}2.49 & & 3.03 & & 3.1 & & 1.67 \\ \%> & 5 & 16 & 25 & 75 & 84 & 95\end{array}$

$\begin{array}{lllllll}0.741 & 1.982 & 2.408 & 3.669 & 4.683 & 7.306\end{array}$

$\% \quad$ Grave Sand Silt Clay $0.178 \quad 82.77 \quad 15.54 \quad 1.509$

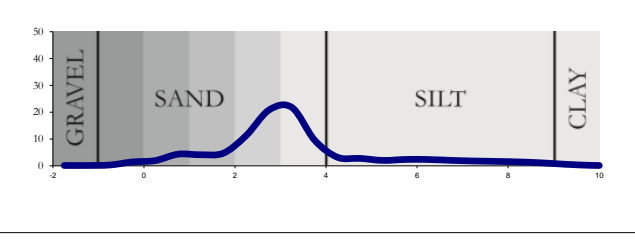

Frequency \%

Cumulative \%

RuaK_Bed3wK\&C_06.\$1s

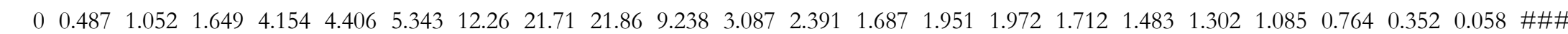
0

Mean:
2.41

2.4

$\begin{array}{llllllllllllllllllllllllll}0 & 0.487 & 1.54 & 3.189 & 7.343 & 11.75 & 17.09 & 29.35 & 51.06 & 72.92 & 82.16 & 85.24 & 87.63 & 89.32 & 91.27 & 93.24 & 94.96 & 96.44 & 97.74 & 98.83 & 99.59 & 99.94 & 100 & 100\end{array}$

Median: Mode: S.D.

$\begin{array}{rrrrrr} & 2.98 & & 2.97 & & 1.536 \\ 5 & 16 & 25 & 75 & 84 & 95\end{array}$

$\% \quad$ Grave Sand Silt Clay

$\begin{array}{llllll}0.744 & 1.918 & 2.352 & 3.566 & 4.265 & 7.011\end{array}$ $0.487 \quad 84.76 \quad 13.58 \quad 1.175$

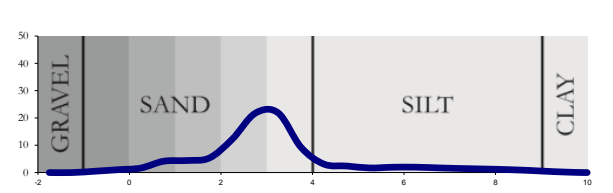


Ruakokopatuna Bridge Section

Class midpoints

Class limits

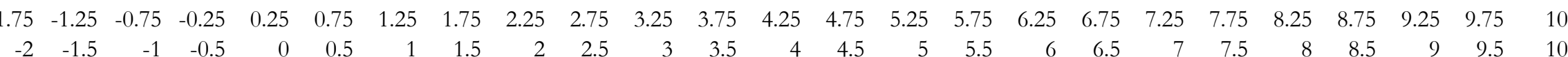

RK 2

Frequency $\%$

Cumulative \%

RuaK BRB2 13.\$1s

Sd

$\begin{array}{lllllllllllllllllllllllll}0 & 0 & 0 & 0 & 0 & 0 & 0 & 0.238 & 4.278 & 17.41 & 27.48 & 16.88 & 6.507 & 4.339 & 2.971 & 3.714 & 3.787 & 3.247 & 2.826 & 2.491 & 2.064 & 1.345 & 0.418 & 0.009 & 0\end{array}$ $\begin{array}{llllllllllllllllllllllllllll}0 & 0 & 0 & 0 & 0 & 0 & 0 & 0.238 & 4.516 & 21.92 & 49.4 & 66.28 & 72.79 & 77.13 & 80.1 & 83.81 & 87.6 & 90.85 & 93.67 & 96.16 & 98.23 & 99.57 & 99.99 & 100 & 100\end{array}$ Mean: Median: Mode: S.D.

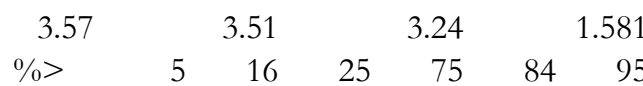

$\begin{array}{rrrrrr}5 & 16 & 25 & 75 & 84 & 95 \\ 2.521 & 2.875 & 3.06 & 4.73 & 6.023 & 7.758\end{array}$

$\% \quad$ Grave Sand Silt Clay $\begin{array}{llll}0 & 72.79 & 25.44 & 1.773\end{array}$

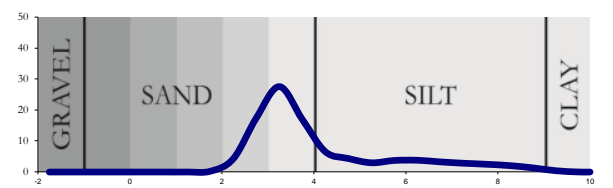

Frequency \%

Cumulative \%

RuaK BRB2 14.\$1s

$\begin{array}{llllllllllllllllllllllll}0 & 0 & 0 & 0 & 0 & 0 & 0.361 & 4.809 & 17.28 & 26.42 & 15.89 & 6.181 & 4.468 & 3.268 & 4.115 & 4.196 & 3.555 & 3.02 & 2.588 & 2.102 & 1.347 & 0.389 & 0.005 & 0\end{array}$ $\begin{array}{lllllllllllllllllllllllllll}0 & 0 & 0 & 0 & 0 & 0 & 0 & 0.361 & 5.17 & 22.45 & 48.87 & 64.77 & 70.95 & 75.41 & 78.68 & 82.8 & 86.99 & 90.55 & 93.57 & 96.16 & 98.26 & 99.61 & 99.99 & 100 & 100\end{array}$ Mean: Median: Mode: S.D.

$\begin{array}{llll}3.58 & 3.52 & 3.24 & 1.619\end{array}$

$\begin{array}{lrrrrrr}\%> & 5 & 16 & 25 & 75 & 84 & 95\end{array}$

$\begin{array}{llllll}2.489 & 2.858 & 3.052 & 4.944 & 6.136 & 7.767\end{array}$

$\begin{array}{llllll}2.431 & 2.79 & 2.95 & 3.917 & 4.838 & 6.993\end{array}$

$\% \quad$ Grave Sand Silt Clay $070.9527 .31 \quad 1.742$

Median \#\#\# $0.00 \quad 0.00$

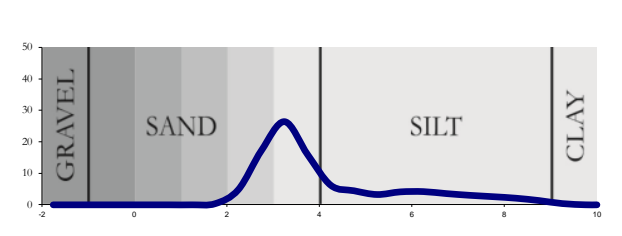


Blue Rock Section Class midpoints Class limits

\section{BR 8 Upper}

Frequency \%

Cumulative \%

BlueRo_Unit8c_28.\$1s

Frequency $\%$

Cumulative \%

BlueRo_Unit8c_27.\$ls

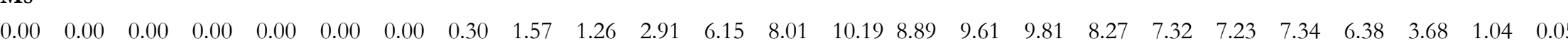

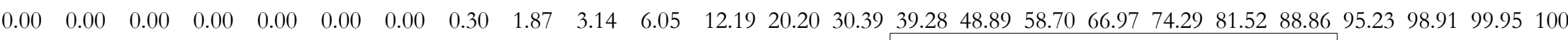
Mean: $\quad$ Median: Mode: S.D

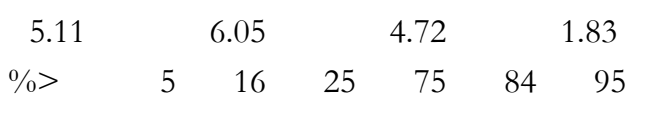

$\begin{array}{llllll}3.38 & 4.26 & 4.74 & 7.55 & 8.17 & 8.98\end{array}$

$\%$ Gravel Sand Silt Clay

$0.00 \quad 20.2068 .66 \quad 11.14$

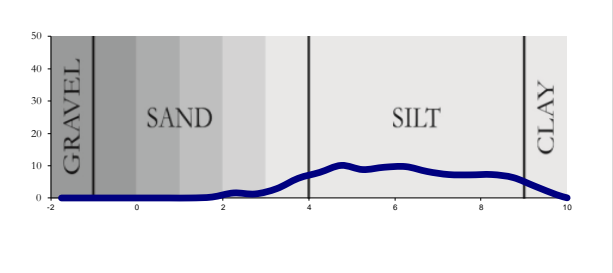

Ms

BR 8 Upper

Frequency $\%$

Cumulative $\%$

BlueRo_Unit8c_26.\$1s

$\begin{array}{lllllllllllllllllllllllll}0.00 & 0.00 & 0.00 & 0.00 & 0.10 & 3.47 & 4.74 & 4.58 & 9.71 & 10.66 & 9.67 & 8.93 & 8.14 & 7.82 & 5.62 & 5.34 & 4.79 & 3.59 & 3.01 & 2.91 & 2.90 & 2.44 & 1.31 & 0.28 & 0.00\end{array}$ $\begin{array}{lllllllllllllllllllllllll}0.00 & 0.00 & 0.00 & 0.00 & 0.10 & 3.57 & 8.31 & 12.89 & 22.60 & 33.25 & 42.92 & 51.85 & 60.00 & 67.82 & 73.44 & 78.78 & 83.56 & 87.15 & 90.16 & 93.08 & 95.97 & 98.41 & 99.71 & 100 & 100\end{array}$

Mean: Median: Mode: S.D.

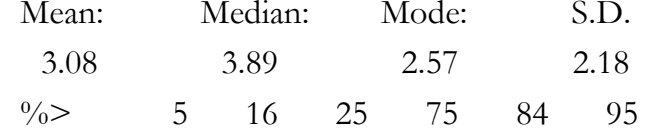

$\begin{array}{rrrrrrr}\%> & 5 & 16 & 25 & 75 & 84 & 95 \\ & 1.12 & 2.19 & 2.61 & 5.65 & 6.55 & 8.33\end{array}$

$\%$ Gravel Sand Silt Clay

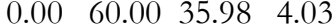

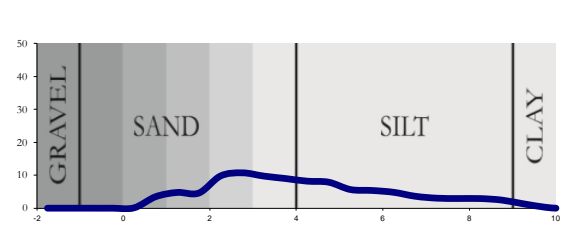

Ms

BR 8 Centre

Frequency $\%$

Cumplo $\%$

BlueRo_Unit8b_25.\$1s

$\begin{array}{lllllllllllllllllllllllll}0.00 & 0.00 & 0.44 & 2.75 & 5.08 & 10.16 & 9.76 & 7.25 & 9.07 & 8.40 & 7.97 & 7.92 & 7.33 & 5.84 & 3.19 & 2.84 & 2.51 & 1.77 & 1.52 & 1.60 & 1.69 & 1.51 & 0.95 & 0.37 & 0.08\end{array}$

Mean: Median: Mode: S.D.

$\begin{array}{lrrrrrr}1.95 & & 2.82 & & 0.95 & & 2.26 \\ \%> & 5 & 16 & 25 & 75 & 84 & 95\end{array}$

$\begin{array}{llllll}0.22 & 0.90 & 1.31 & 4.42 & 5.29 & 7.88\end{array}$

$\%$ Gravel Sand Silt Clay $0.44 \quad 75.6920 .95 \quad 2.91$

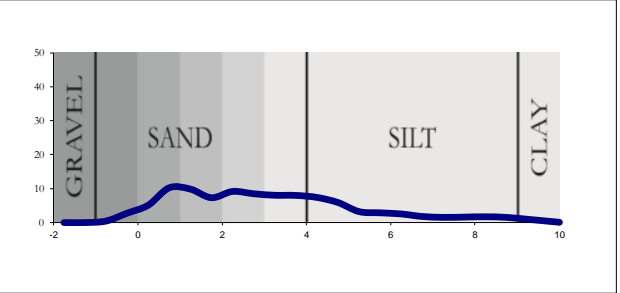


Blue Rock Section Class midpoints Class limits

$\begin{array}{lllllllllllllllllllllllll}-1.75 & -1.25 & -0.75 & -0.25 & 0.25 & 0.75 & 1.25 & 1.75 & 2.25 & 2.75 & 3.25 & 3.75 & 4.25 & 4.75 & 5.25 & 5.75 & 6.25 & 6.75 & 7.25 & 7.75 & 8.25 & 8.75 & 9.25 & 9.75 & 10\end{array}$ $\begin{array}{lllllllllllllllllllllllll}-2.00 & -1.50 & -1.00 & -0.50 & 0.00 & 0.50 & 1.00 & 1.50 & 2.00 & 2.50 & 3.00 & 3.50 & 4.00 & 4.50 & 5.00 & 5.50 & 6.00 & 6.50 & 7.00 & 7.50 & 8.00 & 8.50 & 9.00 & 9.50 & 10\end{array}$

BR 8 Centre

Cumulative \%

BlueRo_Unit8b_24.\$s

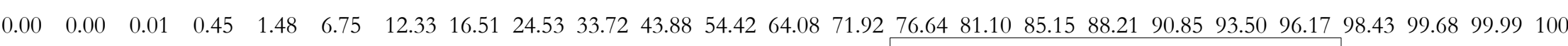

Mean: Median: Mode: S.D.

$\begin{array}{lrrr}2.83 & 3.79 & 3.64 & 2.22\end{array}$

$\begin{array}{lllllll}\%> & 5 & 16 & 25 & 75 & 84 & 95\end{array}$

$\begin{array}{llllll}0.88 & 1.96 & 2.52 & 5.30 & 6.34 & 8.28\end{array}$

$\%$ Gravel Sand Silt Clay

$\begin{array}{llll}0.01 \quad 64.07 & 32.09 & 3.83\end{array}$

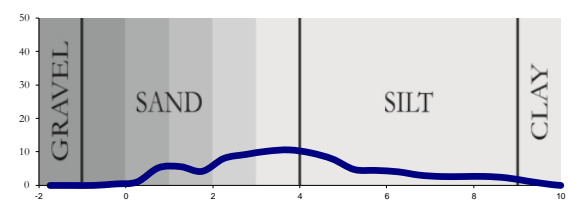

BR 8 Lower

Frequency $\%$

Cumulative $\%$

BlueRo_Unit8a 23.\$

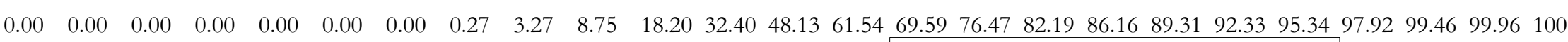

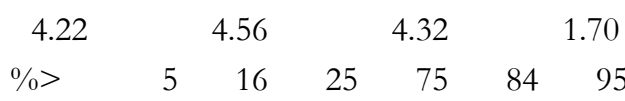

$\begin{array}{llllll}2.67 & 3.41 & 3.75 & 5.89 & 6.71 & 8.44\end{array}$

$\%$ Gravel Sand Silt Clay

$0.00 \quad 48.13 \quad 47.21 \quad 4.66$

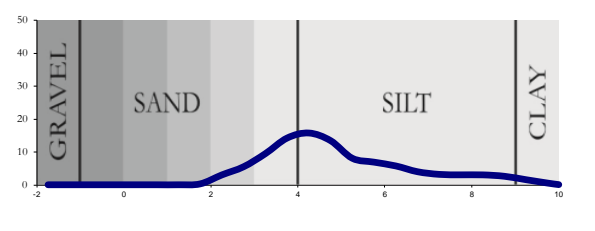

BR 8 Lower

Frequency \%

$\begin{array}{llllllllllllllllllllllllll}0.00 & 0.00 & 0.00 & 0.00 & 0.00 & 0.00 & 0.00 & 0.22 & 3.10 & 7.06 & 12.87 & 18.04 & 17.54 & 12.50 & 6.44 & 5.24 & 4.25 & 2.87 & 2.29 & 2.20 & 2.17 & 1.82 & 1.04 & 0.32 & 0.02\end{array}$

BlueRo_Unit8a_22\$1s

Mean: Median: Mode: S.D
$\begin{array}{cr}\text { Median: } & \text { Mode: } \\ 4.24 & 3.91\end{array}$
$\begin{array}{ll}9 . \mathrm{D} . \\ .91 & 1.54\end{array}$
$\begin{array}{lllllll}\%> & 5 & 16 & 25 & 75 & 84 & 95\end{array}$
$\%$ Gravel Sand Silt Clay
$\begin{array}{llll}0.00 & 58.83 & 37.97 & 3.20\end{array}$

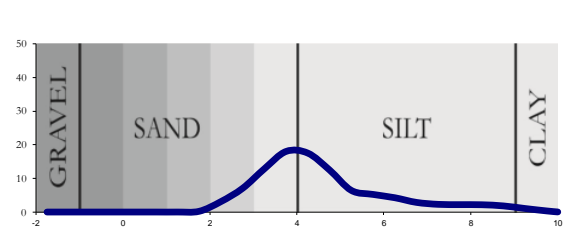

Ms

BR 6 Upper

Frequency $\%$

$\begin{array}{llllllllllllllllllllllll}-0.00 & 0.00 & 0.00 & 0.00 & 0.00 & 0.00 & 0.28 & 5.44 & 11.80 & 13.87 & 14.49 & 13.26 & 10.47 & 6.07 & 5.32 & 4.49 & 3.16 & 2.59 & 2.52 & 2.52 & 2.14 & 1.22 & 0.35 & 0.02\end{array}$

Cumulative \%

BlueRo_Unit6-top_21.\$1s Mean: Median: Mode: S.D.

$\begin{array}{rrrrrrr}3.85 & & 4.15 & & 3.64 & & 1.72 \\ \%> & 5 & 16 & 25 & 75 & 84 & 95\end{array}$

$\begin{array}{lllllll}5.46 & 2.94 & 3.28 & 5.44 & 6.31 & 8.25 & 0\end{array}$

$\%$ Gravel Sand Silt Clay

$0.00 \quad 59.13 \quad 37.14 \quad 3.73$

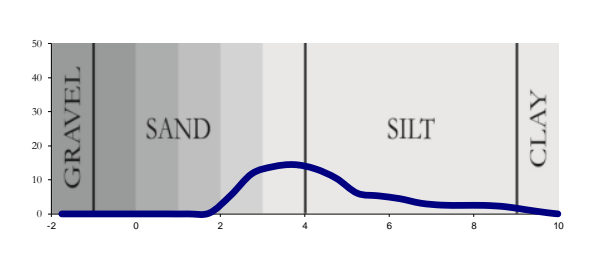


Blue Rock Section Class midpoints Class limits

$\begin{array}{lllllllllllllllllllllllll}-1.75 & -1.25 & -0.75 & -0.25 & 0.25 & 0.75 & 1.25 & 1.75 & 2.25 & 2.75 & 3.25 & 3.75 & 4.25 & 4.75 & 5.25 & 5.75 & 6.25 & 6.75 & 7.25 & 7.75 & 8.25 & 8.75 & 9.25 & 9.75 & 10\end{array}$ BR 6 Upper Ms

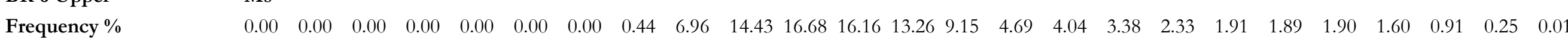

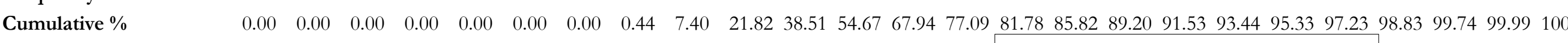
BlueRo_Unit6-top_20.\$1s Mean: Median: Mode: S.D.

$$
\begin{array}{rrrrrrr}
3.65 & & 3.85 & & 3.51 & & 1.58 \\
\%> & 5 & 16 & 25 & 75 & 84 & 95 \\
& 2.39 & 2.81 & 3.10 & 4.85 & 5.78 & 7.91
\end{array}
$$

\section{$\%$ Gravel Sand Silt Clay} $\begin{array}{llll}0.00 & 67.94 & 29.30 & 2.77\end{array}$

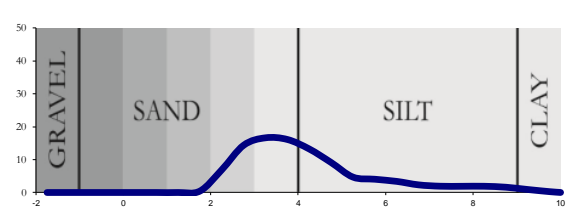

BR 6 Lower M

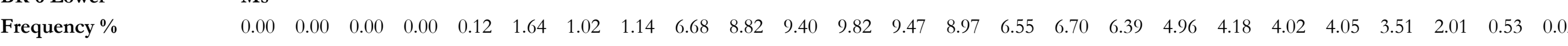

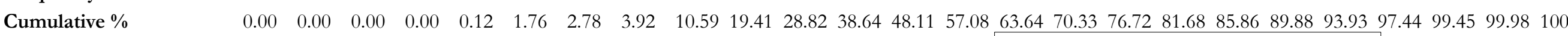
BlueRo_Unit6-base_16.\$ls Mean: Median: Mode: S.D.

$$
\begin{array}{lrrrrrrrrrrr}
3.73 & & 4.60 & & 3.64 & 2.10 & & & & \\
\%> & 5 & 16 & 25 & 75 & 84 & 95 & \text { \% } & \text { Gravel Sand } & \text { Silt } & \text { Clay } \\
& 2.12 & 2.81 & 3.31 & 6.35 & 7.27 & 8.64 & & 0.00 & 48.11 & 45.82 & 6.07
\end{array}
$$

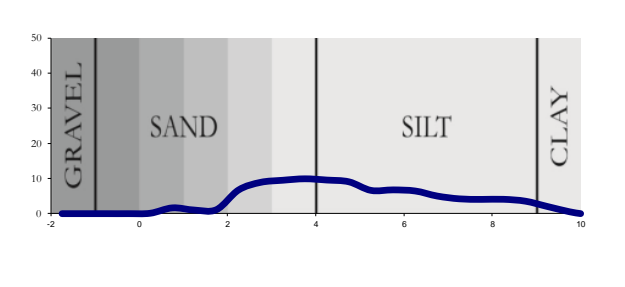

BR 6 Lower Ms

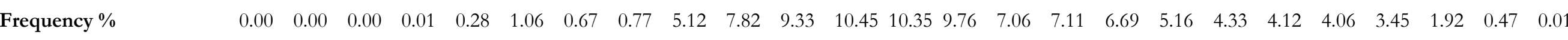

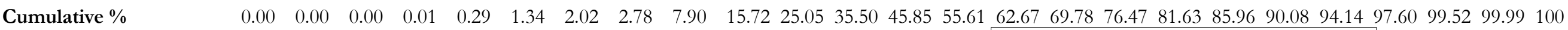

BlueRo_Unit6-base_15.\$1s Mean: Median: Mode: S.D.

$$
\begin{aligned}
& \begin{array}{cccc}
\text { Mean: } & \text { Median: } & \text { Mode: } & \text { S.D. } \\
3.88 & 4.70 & 3.78 & 2.02
\end{array} \\
& \begin{array}{lllllllllll}
\%> & 5 & 16 & 25 & 75 & 84 & 95 & \% & \text { Gravel Sand } & \text { Silt } & \text { Clay }
\end{array} \\
& \begin{array}{llllll}
2.27 & 3.02 & 3.50 & 6.38 & 7.27 & 8.61
\end{array}
\end{aligned}
$$

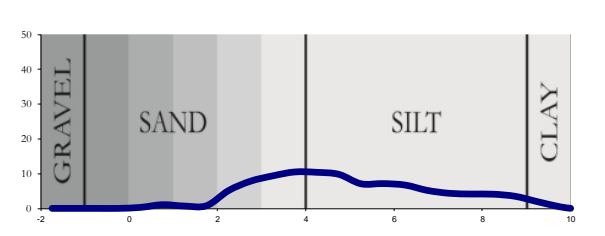

BR 4 Upper Ms

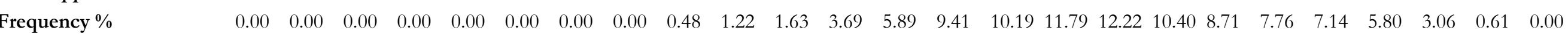

Cumulative $\%$

BlueRo_Unit4-top_14.\$1s Mean: Median: Mode: S.D.

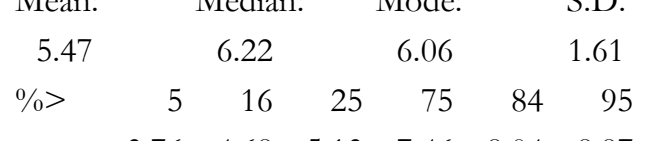

$\%$ Gravel Sand Silt Clay $\begin{array}{llllll}3.76 & 4.68 & 5.13 & 7.46 & 8.04 & 8.87\end{array}$

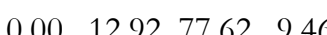

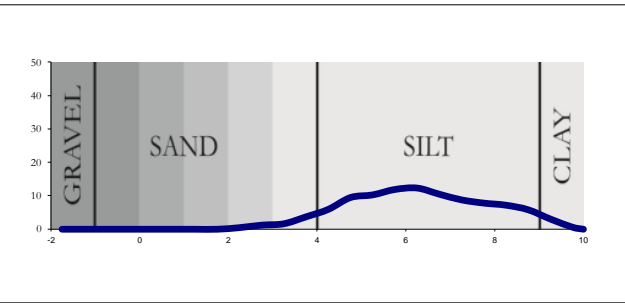


Blue Rock Section

Class midpoints

Class limits

$\begin{array}{lllllllllllllllllllllllll}-1.75 & -1.25 & -0.75 & -0.25 & 0.25 & 0.75 & 1.25 & 1.75 & 2.25 & 2.75 & 3.25 & 3.75 & 4.25 & 4.75 & 5.25 & 5.75 & 6.25 & 6.75 & 7.25 & 7.75 & 8.25 & 8.75 & 9.25 & 9.75 & 10\end{array}$ $\begin{array}{llllllllllllllllllllllllllll}-2.00 & -1.50 & -1.00 & -0.50 & 0.00 & 0.50 & 1.00 & 1.50 & 2.00 & 2.50 & 3.00 & 3.50 & 4.00 & 4.50 & 5.00 & 5.50 & 6.00 & 6.50 & 7.00 & 7.50 & 8.00 & 8.50 & 9.00 & 9.50 & 10\end{array}$

BR 4 Upper

$\begin{array}{llllllllllllllllllllllllllll}\text { Frequency \% } & 0.00 & 0.00 & 0.00 & 0.00 & 0.00 & 0.00 & 0.00 & 0.00 & 0.10 & 0.74 & 1.22 & 3.13 & 5.37 & 9.16 & 10.16 & 11.86 & 12.54 & 10.65 & 8.81 & 7.87 & 7.45 & 6.32 & 3.61 & 0.97 & 0.03\end{array}$

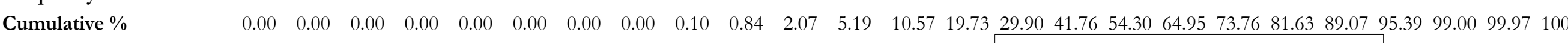
BlueRo_Unit4-top_13.\$ls Mean: Median: Mode: S.D.

$$
\begin{array}{rrrrrrrrrrrr}
5.65 & & 6.32 & & 6.06 & & 1.59 & & & & & \\
\%> & 5 & 16 & 25 & 75 & 84 & 95 & & \text { Gravel Sand } & \text { Silt } & \text { Clay } \\
& 3.98 & 4.81 & 5.26 & 7.58 & 8.16 & 8.96 & & 0.00 & 10.57 & 78.50 & 10.93
\end{array}
$$

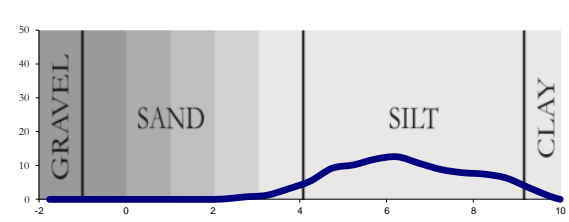

\begin{tabular}{lll}
\hline BR 4 Lower & M \\
Frequency $\%$ & 0.00
\end{tabular}

\begin{tabular}{lllllllllllllllllllllllllllll}
\hline Frequency \% & 0.00 & 0.00 & 0.00 & 0.00 & 0.00 & 0.00 & 0.00 & 0.00 & 0.81 & 3.14 & 3.30 & 4.60 & 5.55 & 6.81 & 6.76 & 8.60 & 10.62 & 10.56 & 9.85 & 9.33 & 8.82 & 7.13 & 3.56 & 0.56 & 0.00
\end{tabular} $\begin{array}{llllllllllllllllllllllllll}\text { Cumulative \% } & 0.00 & 0.00 & 0.00 & 0.00 & 0.00 & 0.00 & 0.00 & 0.00 & 0.82 & 3.96 & 7.25 & 11.86 & 17.41 & 24.22 & 30.98 & 39.57 & 50.19 & 60.75 & 70.60 & 79.93 & 88.75 & 95.88 & 99.43 & 100 & 100\end{array}$ BlueRo_Unit4-base_12.\$ls Mean: Median: Mode: S.D.

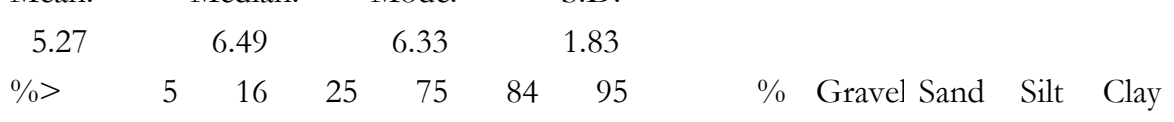

$$
\begin{aligned}
& \begin{array}{llllllllllll}
3.17 & 4.38 & 5.06 & 7.73 & 8.23 & 8.93 & 0.00 & 17.41 & 71.34 & 11.25
\end{array}
\end{aligned}
$$

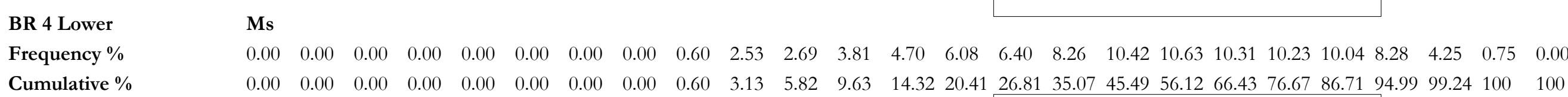

BlueRo_Unit4-base_11.\$ls Mean: Median: Mode: S.D.

$$
\begin{array}{crrrrrr}
\text { Mean: } & & \text { Median: } & \text { Mode: } & & \text { S.D. } \\
5.47 & & 6.71 & & 6.60 & & 1.78 \\
\%> & 5 & 16 & 25 & 75 & 84 & 95 \\
& 3.36 & 4.65 & 5.36 & 7.92 & 8.36 & 9.00
\end{array}
$$

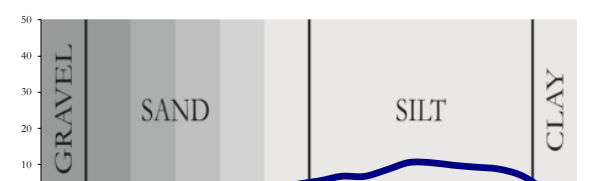

$\begin{array}{llllll}3.36 & 4.65 & 5.36 & 7.92 & 8.36 & 9.00\end{array}$

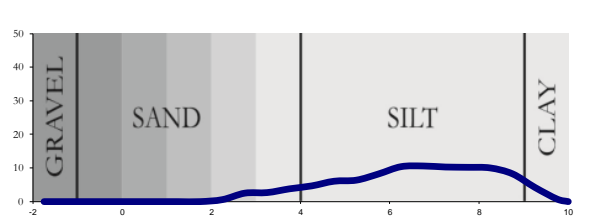

BR 2 Upper Ms

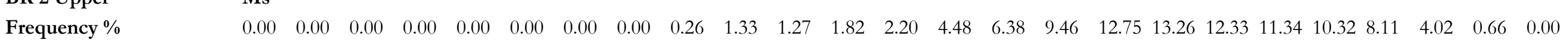

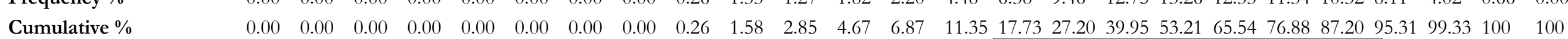

BlueRo_Unit1-top_10.\$ls Mean: Median: Mode: S.D.

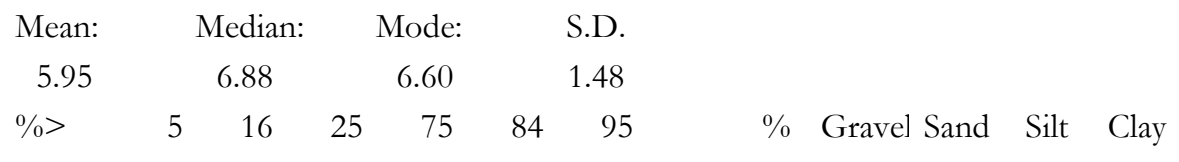

$\begin{array}{lllllll}4.09 & 5.38 & 5.90 & 7.92 & 8.34 & 8.98\end{array}$

$\begin{array}{llll}0.00 & 6.87 & 80.33 & 12.80\end{array}$

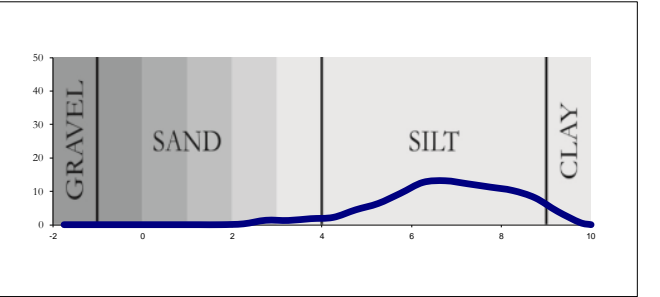


Blue Rock Section Class midpoints Class limits

$\begin{array}{lllllllllllllllllllllllll}-1.75 & -1.25 & -0.75 & -0.25 & 0.25 & 0.75 & 1.25 & 1.75 & 2.25 & 2.75 & 3.25 & 3.75 & 4.25 & 4.75 & 5.25 & 5.75 & 6.25 & 6.75 & 7.25 & 7.75 & 8.25 & 8.75 & 9.25 & 9.75 & 10\end{array}$ $\begin{array}{llllllllllllllllllllllllllll}-2.00 & -1.50 & -1.00 & -0.50 & 0.00 & 0.50 & 1.00 & 1.50 & 2.00 & 2.50 & 3.00 & 3.50 & 4.00 & 4.50 & 5.00 & 5.50 & 6.00 & 6.50 & 7.00 & 7.50 & 8.00 & 8.50 & 9.00 & 9.50 & 10\end{array}$

BR 2 Upper

$\begin{array}{lllllllllllllllllllllllllllll}\text { Frequency \% } & 0.00 & 0.00 & 0.00 & 0.00 & 0.00 & 0.00 & 0.00 & 0.00 & 0.49 & 1.67 & 1.34 & 1.94 & 2.18 & 4.66 & 6.80 & 10.16 & 13.25 & 13.25 & 11.91 & 10.68 & 9.60 & 7.56 & 3.83 & 0.68 & 0.00\end{array}$ Com

$\begin{array}{lllllllllllllllllllllllll}0.00 & 0.00 & 0.00 & 0.00 & 0.00 & 0.00 & 0.00 & 0.00 & 0.49 & 2.16 & 3.51 & 5.44 & 7.62 & 12.28 & 19.08 & 29.24 & 42.49 & 55.73 & 67.64 & 78.32 & 87.93 & 95.49 & 99.32 & 100 & 100\end{array}$

BlueRo_Unit1-top_09.\$ls Mean: Median: Mode: S.D.

$$
\begin{array}{rrrrrrr}
5.83 & & 6.78 & & 6.60 & & 1.52 \\
\%> & 5 & 16 & 25 & 75 & 84 & 95
\end{array}
$$

$\begin{array}{llllll}3.88 & 5.29 & 5.81 & 7.84 & 8.29 & 8.96\end{array}$

\section{$\%$ Gravel Sand Silt Clay} $\begin{array}{llll}0.00 & 7.62 & 80.31 & 12.07\end{array}$

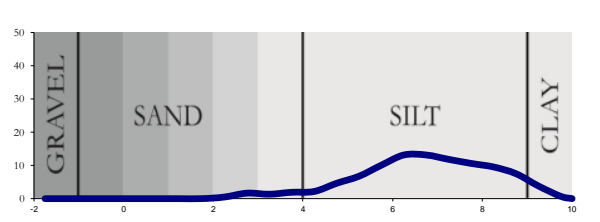

\begin{tabular}{ll}
\hline BR 2 Centre & Ms \\
Frequency \% & 0.00
\end{tabular}

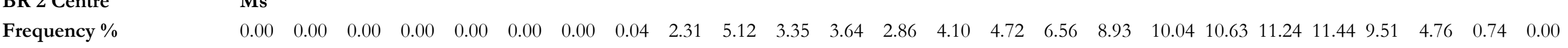

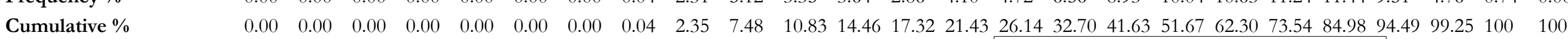
BlueRo_Unit1-cent_08.\$1s Mean: Median: Mode: S.D.

$$
\begin{array}{rrrrrrr|ccccc}
5.15 & & 6.92 & & 8.22 & & 2.00 & & & & & \\
\%> & 5 & 16 & 25 & 75 & 84 & 95 & \text { \% } & \text { Gravel Sand } & \text { Silt } & \text { Clay } \\
& 2.74 & 4.27 & 5.38 & 8.07 & 8.46 & 9.04 & & 0.00 & 17.32 & 67.66 & 15.02
\end{array}
$$

$$
\begin{array}{lllllllr}
\text { BR 2 Centre } & \text { Ms } & & & & & & \\
\text { Frequency \% } & 0.00 & 0.00 & 0.00 & 0.00 & 0.00 & 0.00 & 0.00 \\
\text { Cumulative \% } & 0.00 & 0.00 & 0.00 & 0.00 & 0.00 & 0.00 & 0.00 \\
\text { BlueRo_Unit1-cent_07.\$1s } & \text { Mean: } & \multicolumn{2}{c}{\text { Median: }} & \text { Mode: } & \multicolumn{1}{c}{\text { S.D. }} \\
& 5.25 & & 6.98 & & 8.22 & & 1.93 \\
& \%> & 5 & 16 & 25 & 75 & 84 & 95 \\
& & 2.85 & 4.51 & 5.55 & 8.09 & 8.47 & 9.04
\end{array}
$$

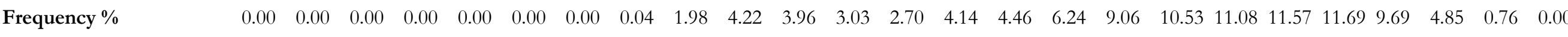

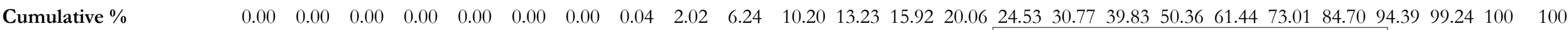

\section{BR 2 Centre}

Frequency \%

Ms

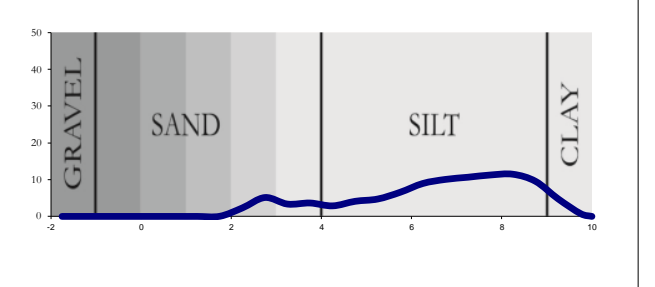

$\begin{array}{lllllllllllllllllllllllll}0.00 & 0.00 & 0.00 & 0.00 & 0.00 & 0.00 & 0.00 & 0.03 & 3.13 & 8.30 & 5.19 & 3.97 & 4.23 & 5.43 & 5.85 & 7.48 & 9.59 & 9.69 & 9.17 & 8.85 & 8.72 & 7.07 & 3.07 & 0.24 & 0.00\end{array}$

Cumulative $\%$

$\begin{array}{llllllllllllllllllllllllll}0.00 & 0.00 & 0.00 & 0.00 & 0.00 & 0.00 & 0.00 & 0.03 & 3.16 & 11.46 & 16.65 & 20.62 & 24.84 & 30.27 & 36.12 & 43.60 & 53.18 & 62.88 & 72.05 & 80.90 & 89.62 & 96.69 & 99.76 & 100 & 100\end{array}$

BlueRo_Unit1-cent_06.\$1s Mean: Median: Mode: S.D.

$$
\begin{array}{rrrrrrr}
4.72 & & 6.34 & & 6.60 & & 2.14 \\
\%> & 5 & 16 & 25 & 75 & 84 & 95 \\
& 2.61 & 3.42 & 4.52 & 7.66 & 8.18 & 8.86
\end{array}
$$

$\%$ Gravel Sand Silt Clay $0.00 \quad 24.8464 .78 \quad 10.38$
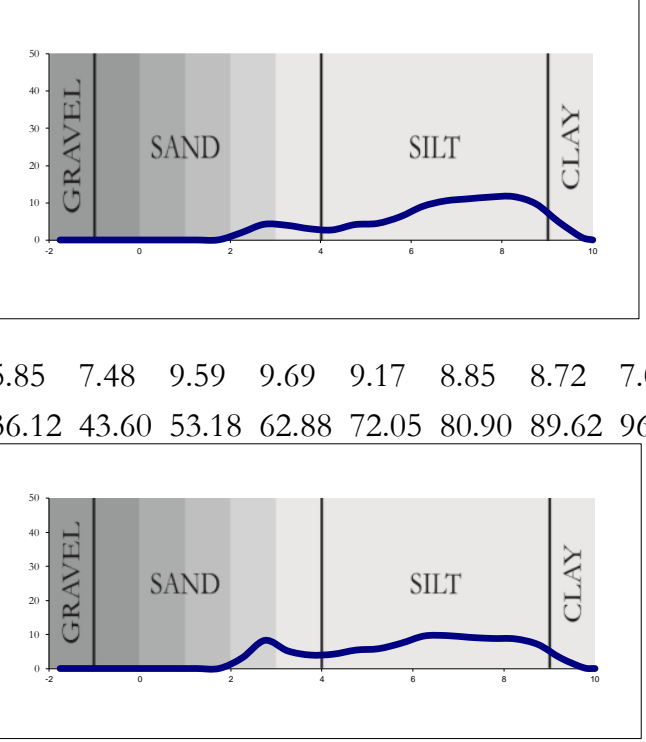
Blue Rock Section Class midpoints Class limits

$\begin{array}{lllllllllllllllllllllllll}-1.75 & -1.25 & -0.75 & -0.25 & 0.25 & 0.75 & 1.25 & 1.75 & 2.25 & 2.75 & 3.25 & 3.75 & 4.25 & 4.75 & 5.25 & 5.75 & 6.25 & 6.75 & 7.25 & 7.75 & 8.25 & 8.75 & 9.25 & 9.75 & 10\end{array}$ $\begin{array}{llllllllllllllllllllllllllll}-2.00 & -1.50 & -1.00 & -0.50 & 0.00 & 0.50 & 1.00 & 1.50 & 2.00 & 2.50 & 3.00 & 3.50 & 4.00 & 4.50 & 5.00 & 5.50 & 6.00 & 6.50 & 7.00 & 7.50 & 8.00 & 8.50 & 9.00 & 9.50 & 10\end{array}$

\section{BR 2 Centre}

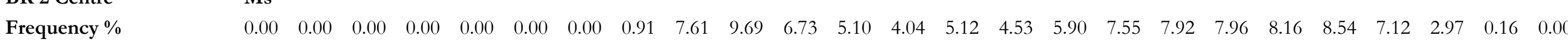

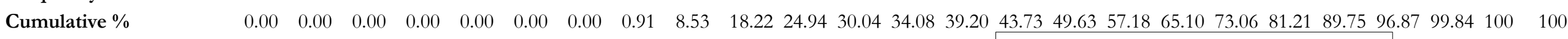
BlueRo_Unit1-cent_05.\$ls Mean: Median: Mode: S.D.

$$
\begin{array}{rrrrrrrrrrrr}
4.23 & & 6.02 & & 2.57 & 2.31 & & & & & \\
\%> & 5 & 16 & 25 & 75 & 84 & 95 & & \text { Gravel Sand } & \text { Silt } & \text { Clay } \\
& 2.32 & 2.87 & 3.50 & 7.62 & 8.17 & 8.84 & & 0.00 & 34.08 & 55.67 & 10.25
\end{array}
$$

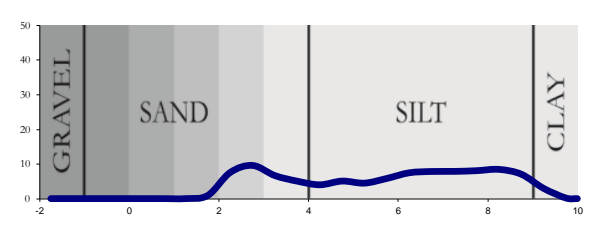

\begin{tabular}{ll}
\hline BR 2 Lower & Ms \\
Frequency \% & 0.00
\end{tabular}

\begin{tabular}{lllllllllllllllllllllllllllll}
\hline BRequency \% & 0.00 & 0.00 & 0.00 & 0.00 & 0.00 & 0.00 & 0.00 & 0.00 & 0.34 & 2.38 & 5.03 & 10.03 & 14.14 & 15.18 & 11.35 & 10.45 & 8.97 & 6.09 & 4.40 & 3.69 & 3.42 & 2.81 & 1.46 & 0.26 & 0.00
\end{tabular}

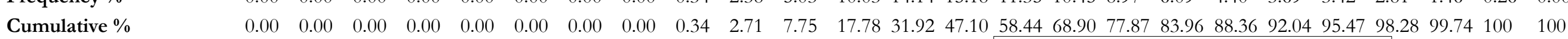
BlueRo_Unit1-base_04.\$1s Mean: Median: Mode: S.D.

$$
\begin{array}{lrrrrrrrrrrr}
4.75 & & 5.11 & & 4.58 & & 1.55 & & & & \\
\%> & 5 & 16 & 25 & 75 & 84 & 95 & \% & \text { Gravel Sand } & \text { Silt } & \text { Clay } \\
& 3.28 & 3.93 & 4.27 & 6.32 & 7.00 & 8.43 & & 0.00 & 31.92 & 63.55 & 4.53
\end{array}
$$

$$
\begin{array}{lcrrrrrrr}
\text { BR 2 Lower } & \text { Ms } & & & & & & & \\
\text { Frequency \% } & 0.00 & 0.00 & 0.00 & 0.00 & 0.00 & 0.00 & 0.00 & 0.00 \\
\text { Cumulative \% } & 0.00 & 0.00 & 0.00 & 0.00 & 0.00 & 0.00 & 0.00 & 0.00 \\
\text { BlueR__Unit1-base_03.\$ls } & \text { Mean: } & \multicolumn{2}{c}{\text { Median: }} & \text { Mode: } & & \text { S.D. } \\
& 4.88 & & 5.28 & & 4.72 & & 1.54 \\
& \%> & 5 & 16 & 25 & 75 & 84 & 95 \\
& & 3.37 & 4.05 & 4.40 & 6.44 & 7.13 & 8.47
\end{array}
$$

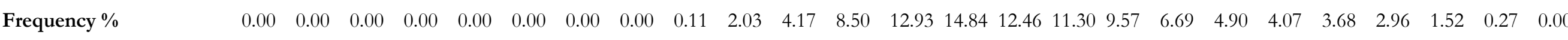

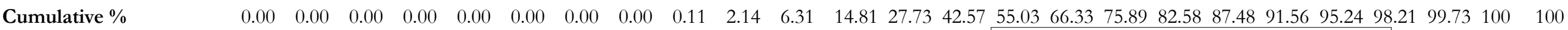

\section{BR 2 Lower}

Frequency \%

Ms

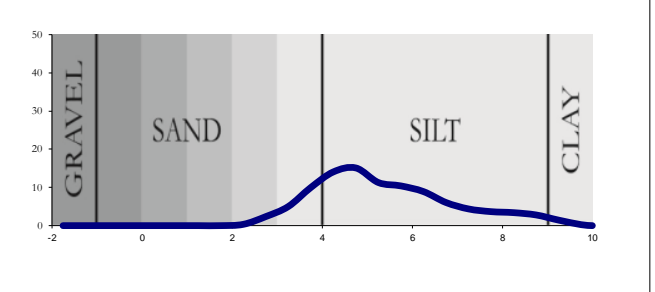

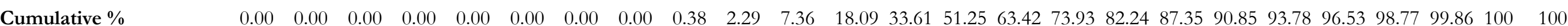

$\begin{array}{llllllllllllllllllllllllll}0.00 & 0.00 & 0.00 & 0.00 & 0.00 & 0.00 & 0.00 & 0.00 & 0.38 & 1.91 & 5.07 & 10.73 & 15.52 & 17.64 & 12.17 & 10.51 & 8.31 & 5.11 & 3.50 & 2.93 & 2.75 & 2.24 & 1.09 & 0.14 & 0.00\end{array}$ BlueRo_Unit1-base_02.\$1s Mean: Median: Mode: S.D.

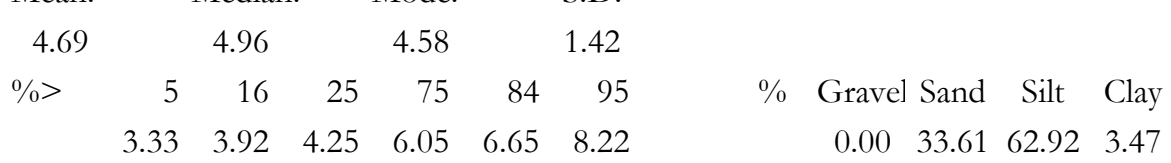
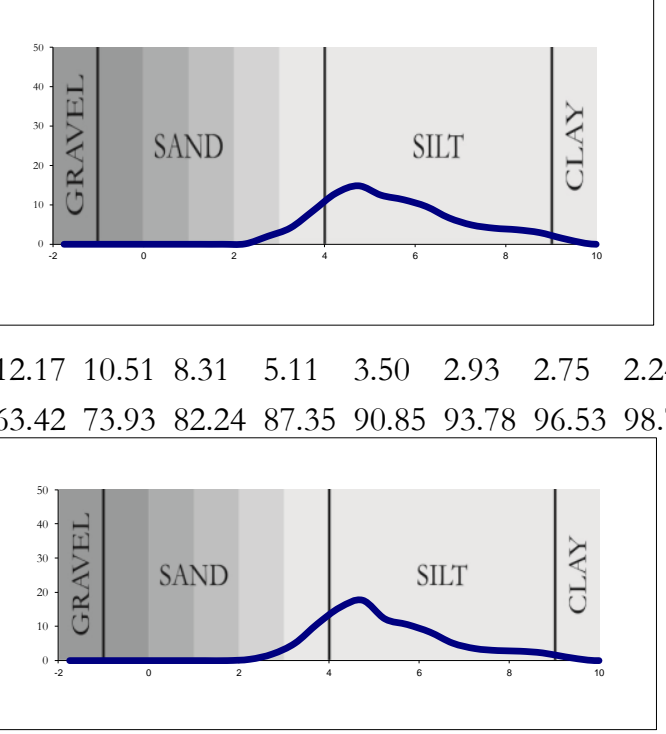
Clay Creek Section

Class midpoints

Class limits

\section{7}

Frequency \%

Cumulative \%

ClayCk_sample9_19.\$1s $\begin{array}{lllllllllllllllllllllllll}-1.75 & -1.25 & -0.75 & -0.25 & 0.25 & 0.75 & 1.25 & 1.75 & 2.25 & 2.75 & 3.25 & 3.75 & 4.25 & 4.75 & 5.25 & 5.75 & 6.25 & 6.75 & 7.25 & 7.75 & 8.25 & 8.75 & 9.25 & 9.75 & 10\end{array}$ $\begin{array}{llllllllllllllllllllllllll}-2.00 & -1.50 & -1.00 & -0.50 & 0.00 & 0.50 & 1.00 & 1.50 & 2.00 & 2.50 & 3.00 & 3.50 & 4.00 & 4.50 & 5.00 & 5.50 & 6.00 & 6.50 & 7.00 & 7.50 & 8.00 & 8.50 & 9.00 & 9.50 & 10\end{array}$

\section{Sw}

$\begin{array}{lllllllllllllllllllllllll}0.00 & 0.00 & 0.00 & 0.00 & 0.02 & 3.65 & 3.11 & 9.30 & 34.75 & 30.41 & 9.45 & 3.29 & 1.20 & 0.99 & 0.53 & 0.65 & 0.64 & 0.49 & 0.45 & 0.42 & 0.37 & 0.23 & 0.04 & 0.00 & 0.00\end{array}$

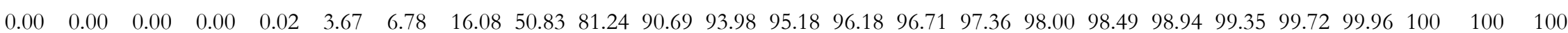
Mean: Median: Mode: S.D.

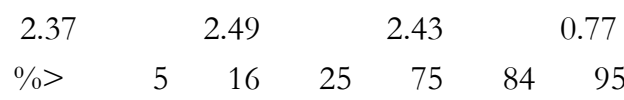

$\begin{array}{llllll}11 & 2 & 2.16 & 2.86 & 3.09 & 4.4\end{array}$

$\%$ Gravel Sand Silt Clay $\begin{array}{llll}0.00 & 95.18 & 4.54 & 0.28\end{array}$

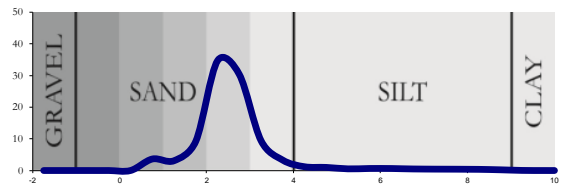

Sw

CC 7

Frequency $\%$

Cumulative \%

ClayCk_sample9_18.\$1 $\begin{array}{lllllllllllllllllllllllllll}0.00 & 0.00 & 0.00 & 0.00 & 0.04 & 3.89 & 7.00 & 16.17 & 50.99 & 81.52 & 90.88 & 94.07 & 95.28 & 96.29 & 96.87 & 97.53 & 98.17 & 98.65 & 99.07 & 99.45 & 99.78 & 99.97 & 100 & 100 & 100\end{array}$ Mean: Median: Mode: S.D.

$$
\begin{aligned}
& \begin{array}{llll}
2.36 & 2.49 & 2.43 & 0.76
\end{array} \\
& \begin{array}{rrrrrrr}
\%> & 5 & 16 & 25 & 75 & 84 & 95 \\
& 1.09 & 2 & 216 & 285 & 3.07 & 4.36
\end{array}
\end{aligned}
$$

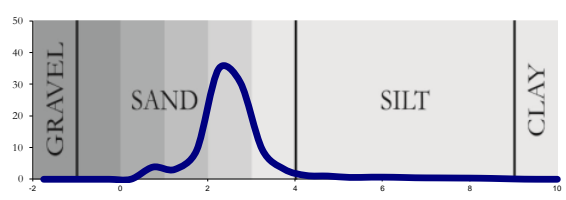

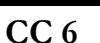

Frequency $\%$

Cumulative \%

ClayCk_sample8_17.\$1

$\mathrm{CC}$

Frequency $\%$

Cumulative \%

ClayCk_sample8_16.\$1s

\section{$\mathrm{SBz}$}

$\begin{array}{lllllllllllllllllllllllll}0.00 & 0.00 & 0.65 & 1.88 & 1.94 & 5.22 & 4.98 & 10.62 & 31.43 & 26.09 & 7.10 & 2.85 & 1.21 & 1.10 & 0.64 & 0.79 & 0.82 & 0.67 & 0.60 & 0.53 & 0.48 & 0.32 & 0.08 & 0.00 & 0.00\end{array}$ $\begin{array}{lllllllllllllllllllllllllll}0.00 & 0.00 & 0.65 & 2.53 & 4.47 & 9.69 & 14.67 & 25.29 & 56.71 & 82.80 & 89.91 & 92.75 & 93.97 & 95.07 & 95.71 & 96.51 & 97.32 & 97.99 & 98.59 & 99.12 & 99.60 & 99.92 & 100 & 100 & 100\end{array}$ Mean: Median: Mode: S.D.

$\begin{array}{llll}2.01 & 2.4 & 2.43 & 1.00\end{array}$

$\begin{array}{lllllll}\%> & 5 & 16 & 25 & 75 & 84 & 95\end{array}$

$\begin{array}{lllllll}0.61 & 1.66 & 1.99 & 2.8 & 3.04 & 4.96\end{array}$

$\%$ Gravel Sand Silt Clay $\begin{array}{llll}0.65 & 93.32 & 5.63 & 0.40\end{array}$

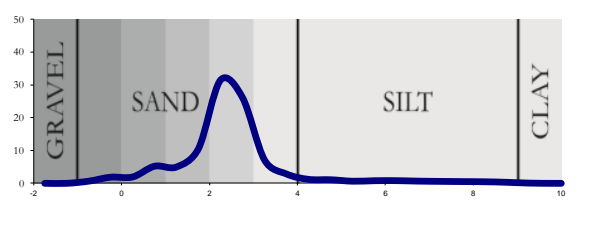

$\mathrm{SBz}$

$\begin{array}{lllllllllllllllllllllllll}0.00 & 0.00 & 0.78 & 1.86 & 2.41 & 5.89 & 5.15 & 10.85 & 31.47 & 25.72 & 6.76 & 2.57 & 1.05 & 0.95 & 0.56 & 0.69 & 0.73 & 0.61 & 0.55 & 0.51 & 0.47 & 0.33 & 0.09 & 0.00 & 0.00\end{array}$ $\begin{array}{lllllllllllllllllllllllllll}0.00 & 0.00 & 0.78 & 2.64 & 5.05 & 10.94 & 16.09 & 26.94 & 58.41 & 84.13 & 90.89 & 93.46 & 94.51 & 95.47 & 96.02 & 96.71 & 97.44 & 98.06 & 98.61 & 99.12 & 99.59 & 99.91 & 100 & 100 & 100\end{array}$ Mean: Median: Mode: S.D.

$\begin{array}{lrrrrrr}1.95 & & 2.38 & & 2.43 & & 1.03 \\ \%> & 5 & 16 & 25 & 75 & 84 & 95\end{array}$
$\begin{array}{llllll}0.47 & 1.47 & 1.96 & 2.77 \quad 3 & 4.75\end{array}$

\% Gravel Sand Silt Clay $\begin{array}{llll}0.78 & 93.73 & 5.07 & 0.41\end{array}$

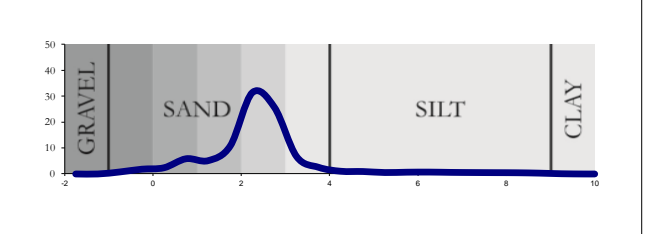


Clay Creek Section

Class midpoints

Class limits

CC 6

Cumulative \%

ClayCk_sample7_15.\$ls
Frequency $\%$

$\begin{array}{lllllllllllllllllllllllll}-1.75 & -1.25 & -0.75 & -0.25 & 0.25 & 0.75 & 1.25 & 1.75 & 2.25 & 2.75 & 3.25 & 3.75 & 4.25 & 4.75 & 5.25 & 5.75 & 6.25 & 6.75 & 7.25 & 7.75 & 8.25 & 8.75 & 9.25 & 9.75 & 10\end{array}$ $\begin{array}{llllllllllllllllllllllllll}-2.00 & -1.50 & -1.00 & -0.50 & 0.00 & 0.50 & 1.00 & 1.50 & 2.00 & 2.50 & 3.00 & 3.50 & 4.00 & 4.50 & 5.00 & 5.50 & 6.00 & 6.50 & 7.00 & 7.50 & 8.00 & 8.50 & 9.00 & 9.50 & 10\end{array}$

$\mathrm{SBz}$

$\begin{array}{lllllllllllllllllllllllll}0.00 & 0.00 & 0.02 & 1.71 & 2.97 & 4.41 & 3.41 & 3.83 & 25.31 & 28.82 & 11.59 & 4.71 & 2.17 & 1.97 & 1.18 & 1.49 & 1.45 & 1.21 & 1.10 & 0.95 & 0.90 & 0.65 & 0.12 & 0.00 & 0.00\end{array}$ $\begin{array}{llllllllllllllllllllllllll}0.00 & 0.00 & 0.02 & 1.74 & 4.71 & 9.12 & 12.53 & 16.36 & 41.68 & 70.50 & 82.09 & 86.80 & 88.98 & 90.94 & 92.12 & 93.61 & 95.06 & 96.27 & 97.37 & 98.32 & 99.23 & 99.88 & 100 & 100 & 100\end{array}$ Mean: Median: Mode: S.D.

$\begin{array}{llll}2.24 & 2.63 & 2.57 & 1.31\end{array}$

$\%>\quad 5 \quad 16 \quad 25 \quad 75 \quad 84 \quad 95$ $\begin{array}{llllll}0.62 & 1.99 & 2.22 & 3.13 & 3.66 & 6.47\end{array}$

$\%$ Gravel Sand Silt Clay $\begin{array}{llll}0.02 & 88.95 & 10.25 & 0.77\end{array}$

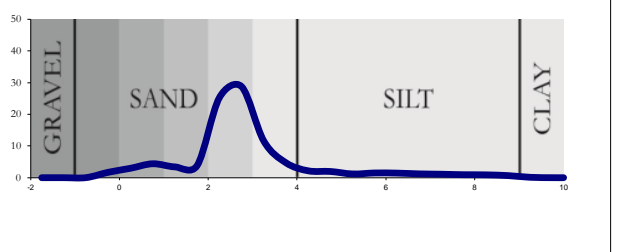

CC 6

Frequency $\%$

Cumulative \%

ClayCk_sample7_14.\$1

\section{$\mathrm{SBz}$}

$\begin{array}{llllllllllllllllllllllllll}0 & 0 & 1.03 & 2.74 & 2.25 & 4.32 & 3.24 & 4.13 & 25.9 & 28.9 & 11.2 & 4.35 & 1.95 & 1.78 & 1.06 & 1.35 & 1.33 & 1.1 & 1 & 0.86 & 0.81 & 0.56 & 0.09 & 0 & 0\end{array}$

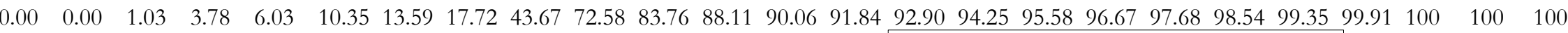
Mean: Median: Mode: S.D.

$\begin{array}{lrrr}2.08 & 2.59 & 2.57 & 1.32\end{array}$

$\begin{array}{llllll}0.17 & 1.93 & 2.18 & 3.06 & 3.52 & 6.26\end{array}$

$\% \quad$ Gravel Sand Silt Clay $\begin{array}{llll}1.03 & 89.03 & 9.29 & 0.65\end{array}$

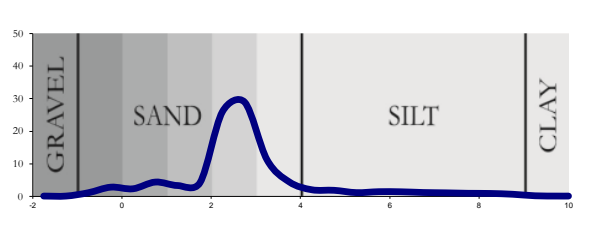

\section{5}

Frequency $\%$

Cumulative \%

ClayCk_sample6_13.\$1 $\begin{array}{lllllllllllllllllllllllll}0 & 0 & 0.93 & 2.27 & 2.78 & 4.78 & 3.38 & 10.5 & 32.5 & 22.1 & 8.03 & 3.69 & 1.65 & 1.44 & 0.82 & 1.02 & 0.98 & 0.79 & 0.72 & 0.64 & 0.59 & 0.41 & 0.08 & 0 & 0\end{array}$ $\begin{array}{llllllllllllllllllllllllll}0.00 & 0.00 & 0.93 & 3.20 & 5.98 & 10.76 & 14.14 & 24.62 & 57.09 & 79.17 & 87.20 & 90.88 & 92.53 & 93.97 & 94.79 & 95.80 & 96.78 & 97.57 & 98.28 & 98.92 & 99.51 & 99.92 & 100 & 100 & 100\end{array}$

Mean: Median: Mode: S.D.

$\begin{array}{rrrr}1.98 & 2.39 & 2.3 & 1.19\end{array}$

$\begin{array}{lllllll}\% & 5 & 16 & 25 & 75 & 84 & 95\end{array}$

$\begin{array}{llllll}0.27 & 1.74 & 2.01 & 2.86 & 3.24 & 5.62\end{array}$

\% Gravel Sand Silt Clay $\begin{array}{llll}0.93 & 91.60 & 6.98 & 0.49\end{array}$

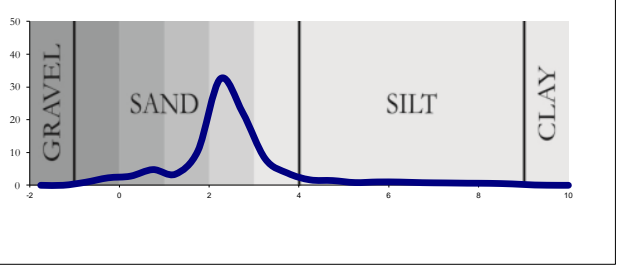

CC 5

Frequency \%

Cumulative \%

ClayCk_sample6_12.\$ls

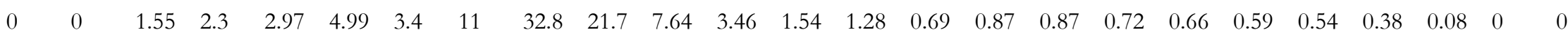
$\begin{array}{lllllllllllllllllllllllllll}0.00 & 0.00 & 1.55 & 3.85 & 6.82 & 11.81 & 15.21 & 26.21 & 58.98 & 80.67 & 88.32 & 91.77 & 93.31 & 94.59 & 95.28 & 96.15 & 97.03 & 97.75 & 98.41 & 99.00 & 99.55 & 99.92 & 100 & 100 & 100\end{array}$ Mean: Median: Mode: $\quad$ S.D.

$\begin{array}{rrrrrrr}1.87 & & 2.36 & & 2.3 & & 1.16 \\ \%> & 5 & 16 & 25 & 75 & 84 & 95 \\ & 0.12 & 1.61 & 1.97 & 2.82 & 3.15 & 5.25\end{array}$

$\%$ Gravel Sand Silt Clay $\begin{array}{llll}1.55 & 91.76 & 6.24 & 0.45\end{array}$

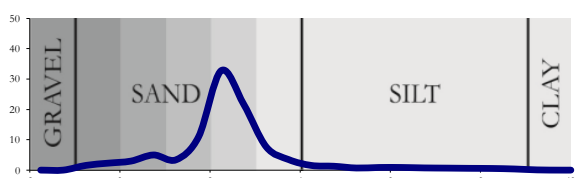


Clay Creek Section

Class midpoints

Class limits

CC 3

Frequency $\%$

Cumulative \%

ClayCk_sample5_11.\$ls

CC 3

Frequency $\%$

Cumulative \%

ClayCk_sample5_10.\$ls $\begin{array}{lllllllllllllllllllllllll}-1.75 & -1.25 & -0.75 & -0.25 & 0.25 & 0.75 & 1.25 & 1.75 & 2.25 & 2.75 & 3.25 & 3.75 & 4.25 & 4.75 & 5.25 & 5.75 & 6.25 & 6.75 & 7.25 & 7.75 & 8.25 & 8.75 & 9.25 & 9.75 & 10\end{array}$

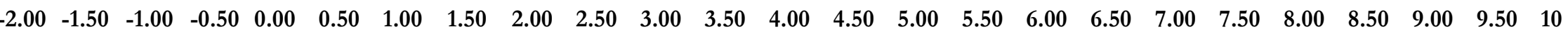

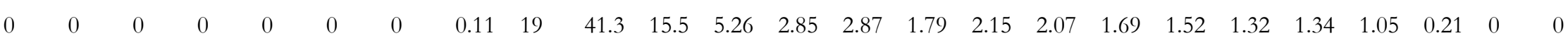

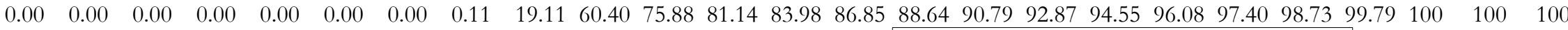
Mean: Median: Mode: S.D.

$\begin{array}{llll}3 & 2.86 & 2.7 & 1.25\end{array}$

$\%>\quad \begin{array}{llllll}\% & 16 & 25 & 75 & 84 & 95\end{array}$ $\begin{array}{llllll}2.27 & 2.45 & 2.57 & 3.44 & 4.5 & 7.14\end{array}$

$\%$ Gravel Sand Silt Clay $\begin{array}{llll}0.00 & 83.98 & 14.75 & 1.27\end{array}$

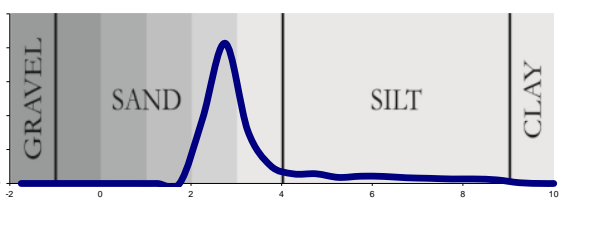

$\begin{array}{lllllllllllllllllllllllll}0 & 0 & 0 & 0 & 0 & 0 & 0 & 0.22 & 21.1 & 45 & 16.6 & 4.92 & 1.96 & 1.85 & 1.07 & 1.36 & 1.34 & 1.1 & 1.01 & 0.9 & 0.86 & 0.6 & 0.11 & 0 & 0\end{array}$

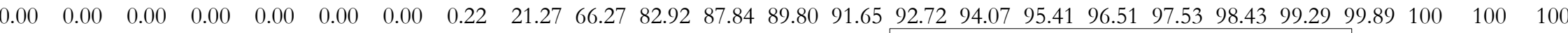
Mean: Median: Mode: S.D

$\begin{array}{lrrr}2.89 & 2.8 & 2.7 & 0.91\end{array}$
$\begin{array}{llllll}2.25 & 2.43 & 2.54 & 3.16 & 3.58 & 6.33\end{array}$

$\% \quad$ Gravel Sand Silt Clay $\begin{array}{llll}0.00 & 89.80 & 9.49 & 0.71\end{array}$

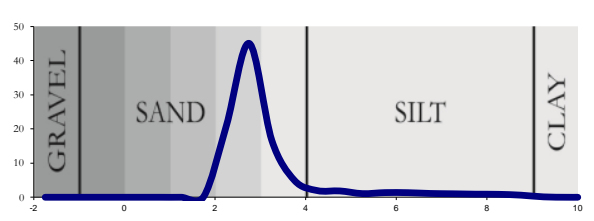

\section{$\mathrm{CC} 3$}

Frequency $\%$

Cumulative \%

ClayCk_sample4_09.\$1

Frequency $\%$

Cumulative \%

ClayCk_sample4_08.\$1 $\begin{array}{lllllllllllllllllllllllll}0 & 0 & 0 & 0 & 0 & 0 & 0 & 0.2 & 20.2 & 45.4 & 18.5 & 5.28 & 1.85 & 1.66 & 0.88 & 1.09 & 1.06 & 0.85 & 0.76 & 0.73 & 0.73 & 0.59 & 0.21 & 0.01 & 0\end{array}$

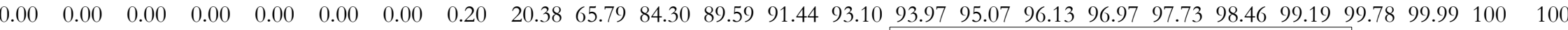
Mean: Median: Mode: S.D.

$\begin{array}{llllll}2.88 & 2.81 & 2.7 & 0.82\end{array}$

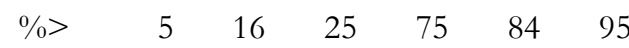

$\begin{array}{llllll}2.26 & 2.44 & 2.55 & 3.15 & 3.48 & 5.97\end{array}$

$\%$ Gravel Sand Silt Clay $\begin{array}{llll}0.00 & 91.44 & 7.76 & 0.81\end{array}$

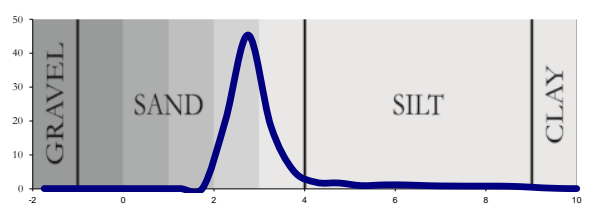

$\begin{array}{lllllllllllllllllllllllll}0 & 0 & 0 & 0 & 0 & 0 & 0 & 0.2 & 20 & 45.2 & 18.3 & 5.16 & 1.83 & 1.68 & 0.94 & 1.21 & 1.16 & 0.94 & 0.84 & 0.8 & 0.82 & 0.66 & 0.23 & 0.01 & 0\end{array}$

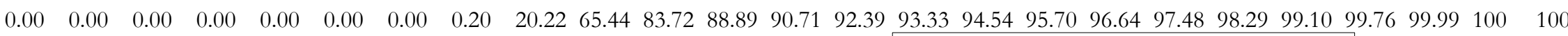
Mean: Median: Mode: S.D

$\begin{array}{lrrrrrr}2.89 & & 2.81 & & 2.7 & & 0.86 \\ \%> & 5 & 16 & 25 & 75 & 84 & 95\end{array}$

$\begin{array}{lllllll}2.26 & 2.44 & 2.55 & 3.17 & 3.52 & 6.18\end{array}$

$\%$ Gravel Sand Silt Clay $\begin{array}{llll}0.00 & 90.71 & 8.39 & 0.90\end{array}$

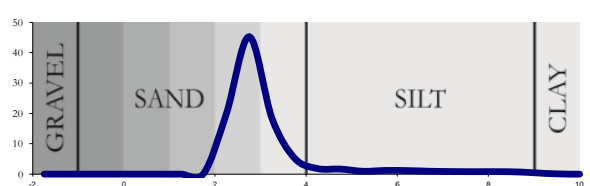


Clay Creek Section

Class midpoints

Class limits

CC 3

Frequency $\%$ $\begin{array}{lllllllllllllllllllllllll}-1.75 & -1.25 & -0.75 & -0.25 & 0.25 & 0.75 & 1.25 & 1.75 & 2.25 & 2.75 & 3.25 & 3.75 & 4.25 & 4.75 & 5.25 & 5.75 & 6.25 & 6.75 & 7.25 & 7.75 & 8.25 & 8.75 & 9.25 & 9.75 & 10\end{array}$ $\begin{array}{llllllllllllllllllllllllllll}-2.00 & -1.50 & -1.00 & -0.50 & 0.00 & 0.50 & 1.00 & 1.50 & 2.00 & 2.50 & 3.00 & 3.50 & 4.00 & 4.50 & 5.00 & 5.50 & 6.00 & 6.50 & 7.00 & 7.50 & 8.00 & 8.50 & 9.00 & 9.50 & 10\end{array}$ Sw 0 $\begin{array}{llll}0.18 & 22.2 & 45.4 & 16\end{array}$

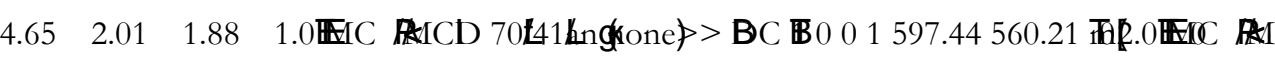


Clay Creek Section

Class midpoints

Class limits

CC 3

Frequency \%

Cumulative \%

ClayCk_sample1_03.\$s

CC 3

Frequency \%

Cumulative \%

ClayCk_sample1_02.\$s

CC 3

Frequency \%

Cumulative \%

ClayCk_sample1_01.\$s $\begin{array}{lllllllllllllllllllllllll}-1.75 & -1.25 & -0.75 & -0.25 & 0.25 & 0.75 & 1.25 & 1.75 & 2.25 & 2.75 & 3.25 & 3.75 & 4.25 & 4.75 & 5.25 & 5.75 & 6.25 & 6.75 & 7.25 & 7.75 & 8.25 & 8.75 & 9.25 & 9.75 & 10\end{array}$ $\begin{array}{llllllllllllllllllllllllll}-2.00 & -1.50 & -1.00 & -0.50 & 0.00 & 0.50 & 1.00 & 1.50 & 2.00 & 2.50 & 3.00 & 3.50 & 4.00 & 4.50 & 5.00 & 5.50 & 6.00 & 6.50 & 7.00 & 7.50 & 8.00 & 8.50 & 9.00 & 9.50 & 10\end{array}$

\section{Sw}

$\begin{array}{llllllllllllllllllllllll}0 & 0 & 0 & 0 & 0 & 0 & 0.24 & 18.2 & 41.4 & 18.2 & 5.95 & 2.65 & 2.64 & 1.67 & 1.99 & 1.87 & 1.43 & 1.3 & 1.05 & 0.9 & 0.51 & 0.03 & 0 & 0\end{array}$

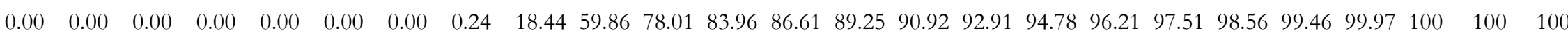
Mean: Median: Mode: S.D.

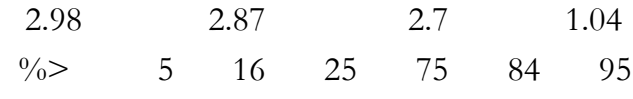
$\begin{array}{llllll}2.26 & 2.46 & 2.58 & 3.34 & 4.01 & 6.57\end{array}$

$\%$ Gravel Sand Silt Clay $\begin{array}{llll}0.00 & 86.61 & 12.85 & 0.54\end{array}$

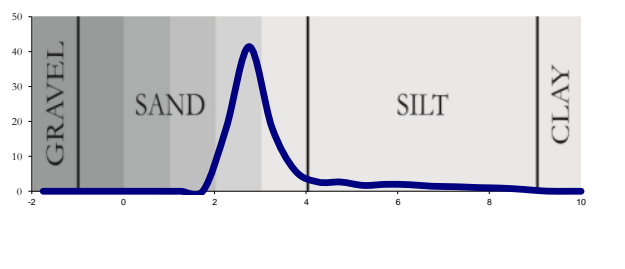

Sw

$\begin{array}{lllllllllllllllllllllllll}0 & 0 & 0 & 0 & 0 & 0 & 0 & 0.29 & 19.5 & 42.8 & 18.3 & 5.51 & 2.15 & 2.12 & 1.34 & 1.65 & 1.59 & 1.27 & 1.18 & 0.98 & 0.85 & 0.5 & 0.04 & 0 & 0\end{array}$ $\begin{array}{lllllllllllllllllllllllll}0.00 & 0.00 & 0.00 & 0.00 & 0.00 & 0.00 & 0.00 & 0.29 & 19.75 & 62.52 & 80.80 & 86.32 & 88.47 & 90.59 & 91.93 & 93.58 & 95.17 & 96.44 & 97.62 & 98.60 & 99.45 & 99.96 & 100 & 100 & 100\end{array}$ Mean: Median: Mode: S.D.

$\begin{array}{llll}2.93 & 2.84 & 2.7 & 0.96\end{array}$

$\begin{array}{rrrrrrr}\%> & 5 & 16 & 25 & 75 & 84 & 95\end{array}$

$\%$ Gravel Sand Silt Clay $\begin{array}{llll}0.00 & 88.47 & 10.99 & 0.55\end{array}$

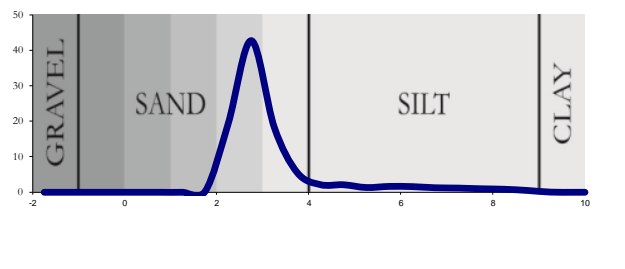

Sw

$\begin{array}{lllllllllllllllllllllllll}0 & 0 & 0 & 0 & 0 & 0 & 0 & 0.84 & 18.3 & 37.5 & 20.1 & 4.81 & 2.9 & 2.67 & 2.15 & 2.18 & 2.11 & 1.85 & 1.58 & 1.3 & 0.96 & 0.58 & 0.21 & 0.02 & 0\end{array}$

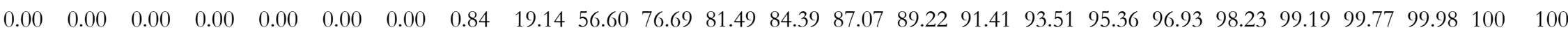
Mean: Median: Mode: S.D.

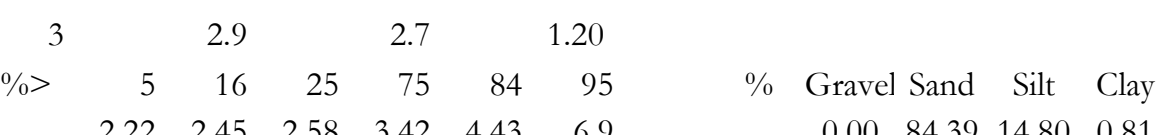

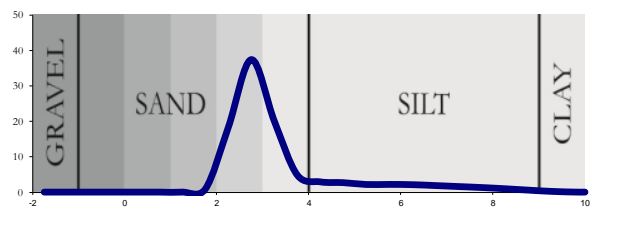


Additional Samples

Class midpoints

Class limits

Ms

Frequency $\%$

Cumulative \%

RuaKRD_TMPoss_05.\$1s $\begin{array}{lllllllllllllllllllllllll}-1.75 & -1.25 & -0.75 & -0.25 & 0.25 & 0.75 & 1.25 & 1.75 & 2.25 & 2.75 & 3.25 & 3.75 & 4.25 & 4.75 & 5.25 & 5.75 & 6.25 & 6.75 & 7.25 & 7.75 & 8.25 & 8.75 & 9.25 & 9.75 & 10\end{array}$

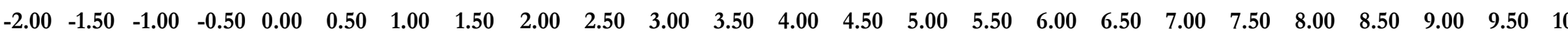

$\begin{array}{lllllllllllllllllllllllll}\# \# \# & 0 & 0 & 0 & 0 & 0 & 0 & 0 & 0.081 & 0.192 & 0.575 & 1.882 & 2.695 & 5.67 & 7.556 & 10.14 & 12.44 & 12.24 & 11.3 & 10.6 & 10.26 & 8.458 & 4.691 & 1.19 & 0.031\end{array}$ $\begin{array}{lllllllllllllllllllllllllll}0.00 & 0.00 & 0.00 & 0.00 & 0.00 & 0.00 & 0.00 & 0.00 & 0.08 & 0.27 & 0.85 & 2.73 & 5.42 & 11.09 & 18.65 & 28.79 & 41.23 & 53.47 & 64.77 & 75.37 & 85.63 & 94.09 & 98.78 & 99.97 & 100\end{array}$ Mean: Median: Mode: S.D.

$\begin{array}{llll}6.12 & 6.85 & 6.33 & 1.47\end{array}$

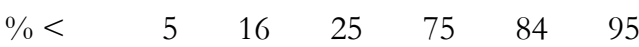

Size $\quad \begin{array}{llllll}4.44 & 5.34 & 5.83 & 7.98 & 8.42 & 9.07\end{array}$

$\% \quad$ Gravel Sand Silt Clay $\begin{array}{llll}0.00 & 5.42 & 80.21 & 14.37\end{array}$

Ms

Frequency \%

Cumulative \%

RuaKRD_TMPoss_06.\$1s

$\begin{array}{llllllll}0 & 0 & 0 & 0 & 0 & 0 & 0\end{array}$

$\begin{array}{lllllll}0.00 & 0.00 & 0.00 & 0.00 & 0.00 & 0.00 & 0.00\end{array}$

Mean: Median: Mode: S.D.

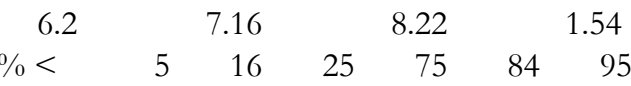

$\begin{array}{lrrrrrr}\text { Size } & 4.38 & 5.36 & 5.96 & 8.22 & 8.60 & 9.18\end{array}$ $\begin{array}{lllllllllllllllllll}0 & 0.007 & 0.228 & 0.763 & 1.998 & 2.92 & 5.492 & 6.35 & 7.941 & 10.04 & 10.82 & 11.22 & 11.72 & 12.25 & 10.51 & 5.991 & 1.673 & 0.077\end{array}$

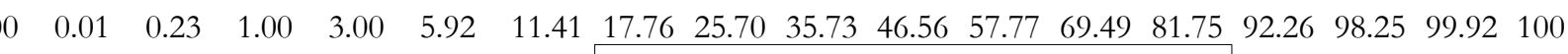

$\%$ Gravel Sand Silt Clay $\begin{array}{llll}0.00 & 5.92 & 75.83 & 18.25\end{array}$

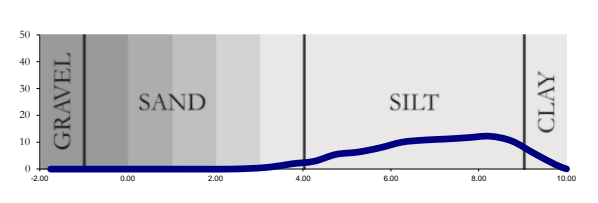

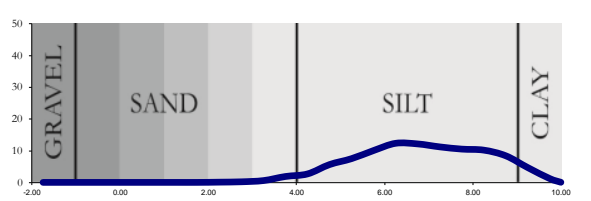

$\overline{\mathrm{S}}$

Frequency $\%$

Cumulative \%

$\begin{array}{llllllllllllll}0 & 0 & 0 & 0 & 0 & 0 & 0 & 0 & 1.598 & 18.42 & 45.3 & 26.77 & 6.208 & 1.699\end{array}$

Ruawak_FarmersBri_03.\$ls Mean: Median: Mode: S.D.

\begin{tabular}{|c|c|c|c|c|c|c|c|c|c|}
\hline 3.3 & & 3.34 & & 3.37 & & 0.44 & & & \\
\hline$\%<$ & 5 & 16 & 25 & 75 & 84 & 95 & Gravel Sand & Silt & Clay \\
\hline Size & 2.67 & 2.94 & 3.07 & 3.62 & 3.77 & 4.19 & $0.00 \quad 98.30$ & 1.70 & 0.00 \\
\hline
\end{tabular}

Sw

Frequency $\%$

$\begin{array}{llllllllllllll}0 & 0 & 0 & 0 & 0 & 0 & 0 & 0 & 1.877 & 19.51 & 45.47 & 25.66 & 5.811 & 1.66\end{array}$

$\begin{array}{ccccccccccccccc}0 & & 0 & & 0 & 0 & 0 & 0 & 0 & 0 & 0 & 0.003 \\ 100 & 100 & 100 & 100 & 100 & 100 & 100 & 100 & 100 & 100 & 100\end{array}$

-

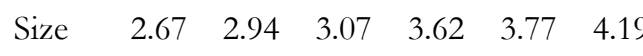

$\begin{array}{llll}0.00 & 98.30 & 1.70 & 0.00\end{array}$

Cumulative \%

$\begin{array}{llllllllllllll}0.00 & 0.00 & 0.00 & 0.00 & 0.00 & 0.00 & 0.00 & 0.00 & 1.88 & 21.39 & 66.86 & 92.53 & 98.34 & 100\end{array}$

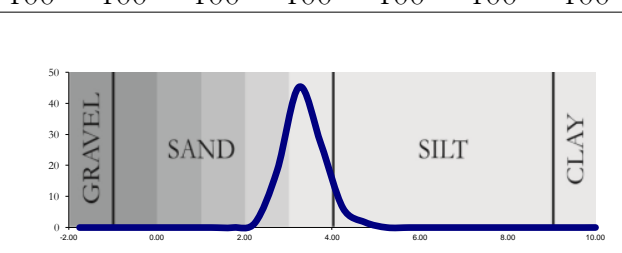

Ruawak_FarmersBri_04.\$ls Mean: Median: Mode: S.D.

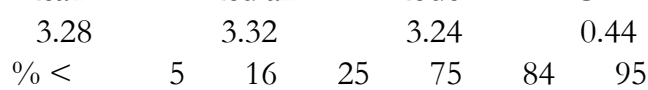

$\begin{array}{lrrrrrr}\%< & 5 & 16 & 25 & 75 & 84 & 95 \\ \text { Size } & 2.66 & 2.92 & 3.05 & 3.60 & 3.75 & 4.17\end{array}$

$\%$ Gravel Sand Silt Clay $\begin{array}{llll}0.00 & 98.34 & 1.66 & 0.00\end{array}$

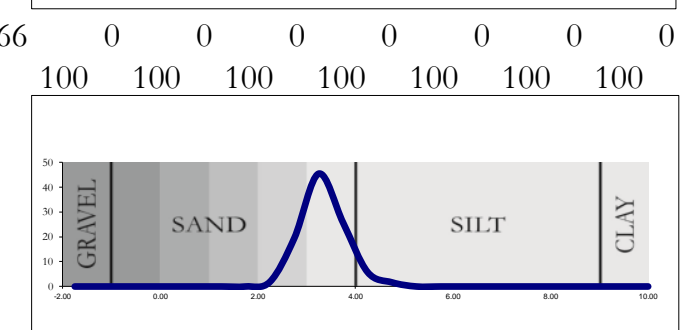


Additional Samples Class midpoints Class limits

Frequency \%

Cumulative \%

TTH_mud_19.\$ls

Ms

Frequency \%

Cumulative \%

TTH_mud_20.\$s

$\begin{array}{lllllllllllllllllllllllll}-1.75 & -1.25 & -0.75 & -0.25 & 0.25 & 0.75 & 1.25 & 1.75 & 2.25 & 2.75 & 3.25 & 3.75 & 4.25 & 4.75 & 5.25 & 5.75 & 6.25 & 6.75 & 7.25 & 7.75 & 8.25 & 8.75 & 9.25 & 9.75 & 10\end{array}$

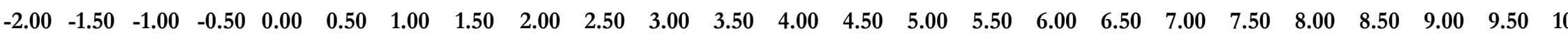

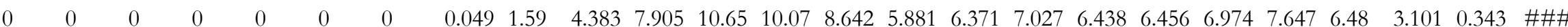
$\begin{array}{lllllllllllllllllllllllll}0.00 & 0.00 & 0.00 & 0.00 & 0.00 & 0.00 & 0.00 & 0.05 & 1.64 & 6.02 & 13.93 & 24.58 & 34.64 & 43.28 & 49.16 & 55.54 & 62.56 & 69.00 & 75.45 & 82.43 & 90.08 & 96.56 & 99.66 & 100 & 100\end{array}$ Mean: Median: Mode: S.D. $\begin{array}{lrrrr}4.65 & 5.58 & 3.78 & 2.03\end{array}$

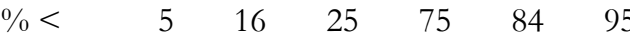

Size $\quad \begin{array}{llllll}2.91 & 3.60 & 4.02 & 7.47 & 8.10 & 8.86\end{array}$

$\% \quad$ Gravel Sand Silt Clay $\begin{array}{llll}0.00 & 34.64 & 55.43 \quad 9.92\end{array}$

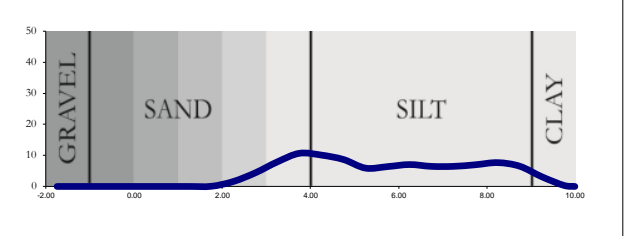

$\begin{array}{lllllllllllllllllllllllll}0.00 & 0.00 & 0.00 & 0.00 & 0.00 & 0.00 & 0.00 & 0.06 & 1.99 & 5.36 & 9.72 & 11.53 & 11.03 & 9.15 & 5.93 & 6.28 & 6.78 & 6.10 & 5.89 & 6.09 & 6.41 & 5.20 & 2.29 & 0.18 & 0.00\end{array}$ $\begin{array}{lllllllllllllllllllllllllll}0.00 & 0.00 & 0.00 & 0.00 & 0.00 & 0.00 & 0.00 & 0.06 & 2.06 & 7.42 & 17.14 & 28.67 & 39.70 & 48.84 & 54.78 & 61.06 & 67.84 & 73.94 & 79.83 & 85.92 & 92.33 & 97.53 & 99.82 & 100 & 100\end{array}$ Mean: Median: Mode: S.D.

$\begin{array}{lrrrrr}4.46 & 5.08 & 3.64 & 2.00\end{array}$

Size $\quad \begin{array}{llllll}2.81 & 3.45 & 3.84 & 7.09 & 7.84 & 8.73\end{array}$

$\%$ Gravel Sand Silt Clay $\begin{array}{llll}0.00 & 39.70 & 52.63 & 7.67\end{array}$

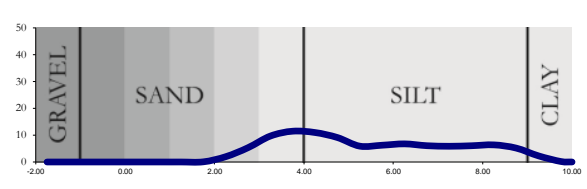

Ms

Frequency $\%$

Cumulative \%

$0 \quad 0$

$\begin{array}{lllllllllllllllll}0.973 & 10.44 & 18.61 & 15.11 & 9.698 & 6.62 & 5.683 & 4.016 & 4.22 & 4.353 & 3.65 & 3.318 & 3.381 & 3.548 & 3.207 & 2.099 & 0.878\end{array}$ $\begin{array}{lllllllllllllllll}0.973 & 11.41 & 30.02 & 45.13 & 54.83 & 61.45 & 67.13 & 71.15 & 75.37 & 79.72 & 83.37 & 86.69 & 90.07 & 93.62 & 96.82 & 98.92 & 99.8\end{array}$

RuaK_WSampleLow_28.\$1s Mean: Median: Mode: S.D.

$\begin{array}{lrrrrrr}3.57 & & 3.72 & & 2.84 & & 2.09 \\ \%< & 5 & 16 & 25 & 75 & 84 & 95 \\ \text { Size } & 2.27 & 2.63 & 2.86 & 5.96 & 7.09 & 8.70\end{array}$

$\% \quad$ Gravel Sand Silt Clay $\begin{array}{llll}0.00 & 54.83 & 35.24 & 9.73\end{array}$

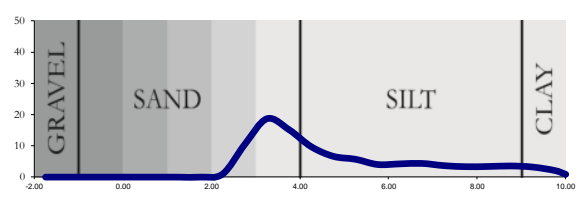

Ms

Frequency $\%$

Cumulative \%

RuaK_WestSample_27.\$ls Mean: Median: Mode: S.D.

$\begin{array}{llll}3.87 & 4.34 & 2.84 & 2.17\end{array}$

$\%<\quad \begin{array}{rrrrrr}0 & 16 & 25 & 75 & 84 & 95\end{array}$

$\begin{array}{lllllll}\text { Size } & 2.40 & 2.82 & 3.13 & 6.52 & 7.60 & 8.87\end{array}$ $\begin{array}{llllllllllllllllll}0 & 0.457 & 6.754 & 14.05 & 13.15 & 10.03 & 7.992 & 7.168 & 4.856 & 5.11 & 5.267 & 4.391 & 3.997 & 4.153 & 4.49 & 4.128 & 2.676 & 1.091\end{array}$

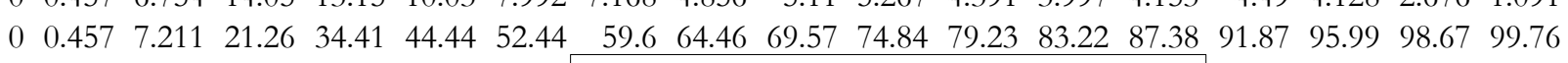

$\%$ Gravel Sand Silt Clay $\begin{array}{llll}0.00 & 44.44 & 42.93 & 12.38\end{array}$

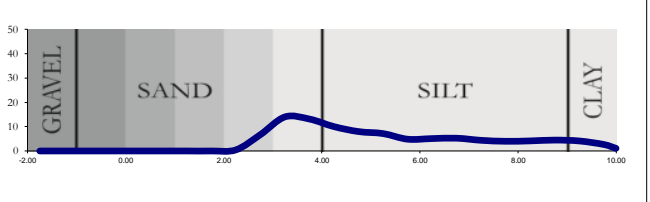


Additional Samples

Class midpoints

$\begin{array}{lllllllllllllllllllllllll}-1.75 & -1.25 & -0.75 & -0.25 & 0.25 & 0.75 & 1.25 & 1.75 & 2.25 & 2.75 & 3.25 & 3.75 & 4.25 & 4.75 & 5.25 & 5.75 & 6.25 & 6.75 & 7.25 & 7.75 & 8.25 & 8.75 & 9.25 & 9.75 & 10\end{array}$ Class limits

Ms

Frequency $\%$

Cumulative \%

RuaK_WestSample_26.\$1s

$\begin{array}{llllllll}0 & 0 & 0 & 0 & 0 & 0 & 0 \\ 0 & 0 & 0 & 0 & 0 & 0 & 0\end{array}$

$\begin{array}{lllllllllllllllllll}\text { \#\#\# } & 0.925 & 6.599 & 9.858 & 8.604 & 7.001 & 6.228 & 7.069 & 5.944 & 6.325 & 6.487 & 5.561 & 5.256 & 5.749 & 6.451 & 6.003 & 3.903 & 1.629\end{array}$ $\begin{array}{lllllllllllllllll}\text { \#\#\# } 0.925 & 7.525 & 17.38 & 25.99 & 32.99 & 39.22 & 46.28 & 52.23 & 58.55 & 65.04 & 70.6 & 75.86 & 81.61 & 88.06 & 94.06 & 97.96 & 99.59\end{array}$ Mean: Median: Mode: S.D.

$\begin{array}{llll}4.15 & 5.30 & 2.70 & 2.34\end{array}$

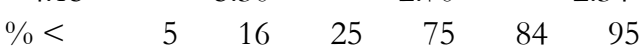

$\begin{array}{lllllll}\text { Size } & 2.36 & 2.93 & 3.44 & 7.42 & 8.19 & 9.10\end{array}$

Ms

Frequency $\%$

Cumulative \%

RuaK_WestSample_25.\$1s

$0 \quad 0$

0

Mea

3.96

$\begin{array}{llllll}5 & 16 & 25 & 75 & 84 & 95\end{array}$

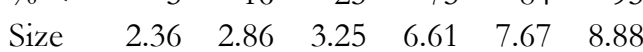

$\%$ Gravel Sand Silt Clay $\begin{array}{llll}0.00 & 32.99 & 48.62 & 17.99\end{array}$

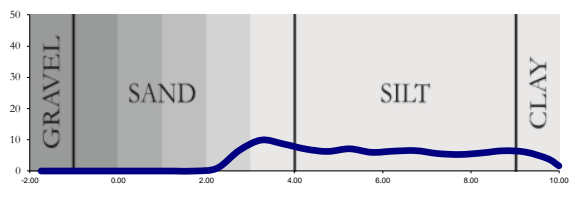

$\begin{array}{lllllllllllllllll}0.716 & 7.039 & 11.63 & 10.93 & 9.204 & 8.213 & 8.249 & 6.033 & 6.061 & 5.824 & 4.58 & 4.112 & 4.332 & 4.713 & 4.3 & 2.757 & 1.091\end{array}$

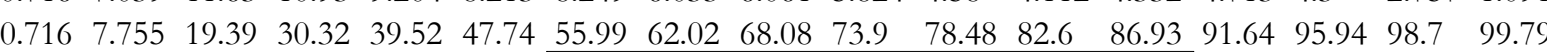

$\% \quad$ Gravel Sand Silt Clay $\begin{array}{llll}0.00 & 39.52 & 47.40 & 12.86\end{array}$

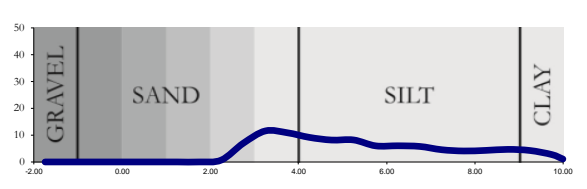

Ms

Frequency $\%$

Cumulative \%

RuaK_River Samp_24.\$1s

$0 \quad 0$

0

Mean:

5.18

$\%<$

Size

$\begin{array}{lll}0 & 0 \\ 0 & 0 & 0\end{array}$

$0 \quad 0$

Median:

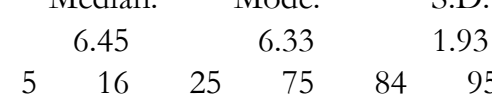

Ms

Frequency $\%$

Cumulative \%

RuaK_River Samp_23.\$1s

\section{$0 \quad 0$} 0 Mean:

$\begin{array}{lrrrrrr}5.20 & & 6.54 & & 6.33 & & 1.92 \\ \%< & 5 & 16 & 25 & 75 & 84 & 95 \\ \text { Size } & 2.97 & 4.36 & 5.13 & 7.85 & 8.35 & 9.07\end{array}$

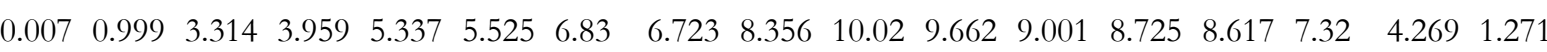
$\begin{array}{lllllllllllllllll}0.007 & 1.006 & 4.319 & 8.279 & 13.62 & 19.14 & 25.97 & 32.69 & 41.05 & 51.07 & 60.73 & 69.73 & 78.46 & 87.07 & 94.39 & 98.66 & 99.93\end{array}$

$\% \quad$ Gravel Sand Silt Clay $\begin{array}{llll}0.00 & 13.62 & 64.84 & 21.48\end{array}$

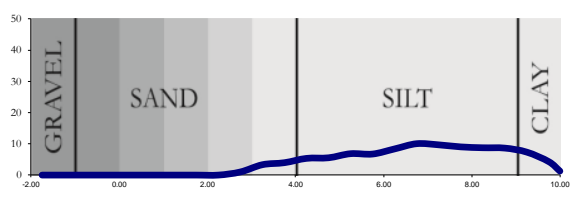

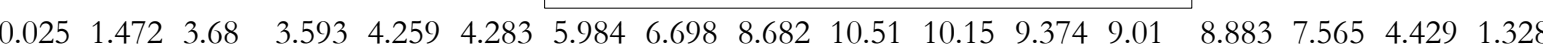
$\begin{array}{llllllllllllllllll}0.025 & 1.498 & 5.177 & 8.77 & 13.03 & 17.31 & 23.3 & 29.99 & 38.68 & 49.19 & 59.34 & 68.71 & 77.72 & 86.61 & 94.17 & 98.6 & 99.93\end{array}$

$\% \quad$ Gravel Sand Silt Clay $\begin{array}{llll}0.00 & 13.03 & 64.69 & 22.21\end{array}$

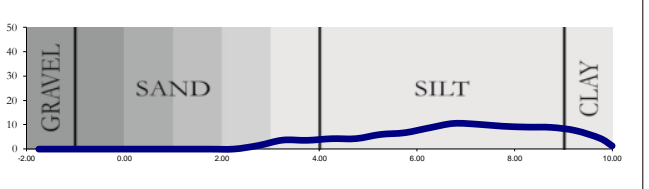


Additional Samples Class midpoints Class limits

\section{Sp}

Frequency \%

Cumulative \%

RuaK_Bridge4_20.\$1

Sp

Frequency \%

Cumulative \%

RuaK_Bridge4_19.\$l

Sp

Frequency $\%$

Cumulative \%

RuaK_Bridge3_22.\$1

Sp

Frequency \%

Cumulative \%

RuaK_Bridge1_21.\$1

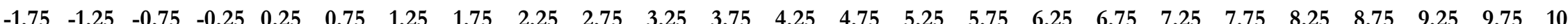

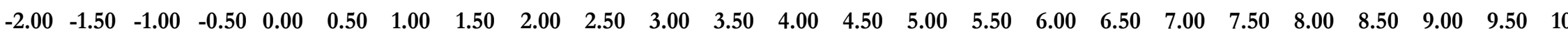

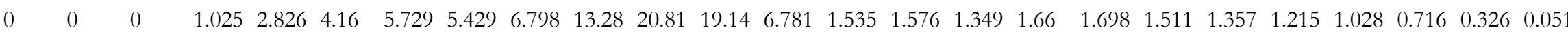
$\begin{array}{lllllllllllllllllllllllllll}0 & 0 & 0 & 1.025 & 3.85 & 8.01 & 13.74 & 19.17 & 25.97 & 39.25 & 60.06 & 79.2 & 85.98 & 87.51 & 89.09 & 90.44 & 92.1 & 93.8 & 95.31 & 96.66 & 97.88 & 98.91 & 99.62 & 99.95 & 100\end{array}$ Mean: Median: Mode: S.D. $\begin{array}{llll}1.99 & 2.77 & 2.97 & 1.67\end{array}$

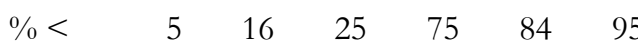

Size $\quad 0.12 \quad 1.17 \quad 1.94 \quad 3.36 \quad 3.75 \quad 6.89$

$\%$ Gravel Sand Silt Clay $\begin{array}{llll}0.00 & 85.98 & 11.90 & 2.12\end{array}$

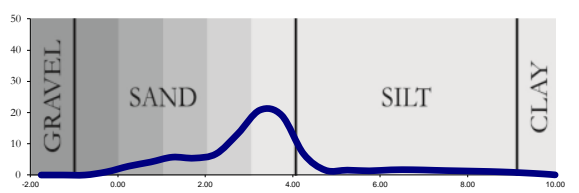

$\begin{array}{llllllllllllllllllllllllll}0 & 0 & 0 & 0.712 & 2.106 & 3.421 & 5.236 & 4.718 & 6.207 & 13.35 & 21.74 & 20.33 & 7.253 & 1.632 & 1.728 & 1.477 & 1.799 & 1.836 & 1.622 & 1.441 & 1.273 & 1.058 & 0.718 & 0.308 & 0.035\end{array}$ $\begin{array}{lllllllllllllllllllllllllll}0 & 0 & 0 & 0.712 & 2.818 & 6.239 & 11.48 & 16.19 & 22.4 & 35.75 & 57.49 & 77.82 & 85.07 & 86.71 & 88.43 & 89.91 & 91.71 & 93.54 & 95.17 & 96.61 & 97.88 & 98.94 & 99.66 & 99.97 & 100\end{array}$ Mean: Median: Mode: S.D. $\begin{array}{llll}2.15 & 2.84 & 2.97 & 1.60\end{array}$ $\begin{array}{lllllll}\% & 5 & 16 & 25 & 75 & 84 & 95\end{array}$ $\begin{array}{lllllll}\text { Size } & 0.33 & 1.47 & 2.12 & 3.41 & 3.84 & 6.94\end{array}$

$\% \quad$ Gravel Sand Silt Clay $\begin{array}{llll}0.00 & 85.07 & 12.81 & 2.12\end{array}$

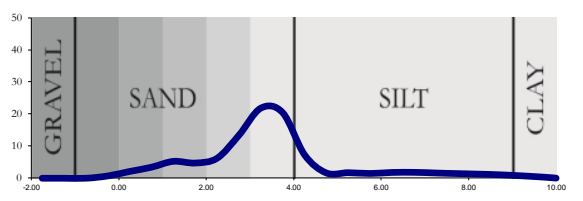

$\begin{array}{llllllllllllllllllllllllll}0 & 0 & 0 & 0.235 & 0.825 & 1.677 & 3.681 & 3.054 & 3.758 & 11.93 & 24.47 & 24.54 & 8.658 & 1.909 & 2.093 & 1.868 & 2.274 & 2.274 & 1.944 & 1.636 & 1.342 & 1.017 & 0.61 & 0.203 & 0.009\end{array}$ $\begin{array}{lllllllllllllllllllllllllll}0 & 0 & 0 & 0.235 & 1.06 & 2.736 & 6.418 & 9.472 & 13.23 & 25.15 & 49.63 & 74.16 & 82.82 & 84.73 & 86.82 & 88.69 & 90.96 & 93.24 & 95.18 & 96.82 & 98.16 & 99.18 & 99.79 & 99.99 & 100\end{array}$ Mean: Median: Mode: S.D.

$\begin{array}{llll}2.55 & 3.01 & 2.97 & 1.46\end{array}$

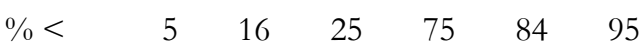

Size $\quad \begin{array}{llllll}0.83 & 2.16 & 2.49 & 3.53 & 4.29 & 6.95\end{array}$

$\%$ Gravel Sand Silt Clay $\begin{array}{llll}0.00 & 82.82 & 15.34 & 1.84\end{array}$

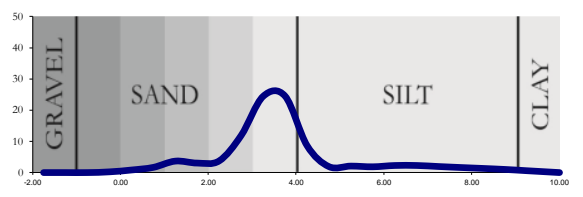

$\begin{array}{lllllllllllllllllllllllll}0 & 0 & 0 & 0.079 & 0.391 & 0.793 & 2.365 & 1.522 & 1.153 & 9.239 & 25.47 & 28.74 & 11.28 & 2.825 & 2.532 & 1.865 & 2.195 & 2.226 & 1.947 & 1.699 & 1.459 & 1.164 & 0.746 & 0.286 & 0.02\end{array}$ $\begin{array}{lllllllllllllllllllllllll}0 & 0 & 0 & 0.079 & 0.47 & 1.263 & 3.628 & 5.15 & 6.303 & 15.54 & 41.01 & 69.76 & 81.04 & 83.86 & 86.4 & 88.26 & 90.45 & 92.68 & 94.63 & 96.33 & 97.79 & 98.95 & 99.69 & 99.98 & 100\end{array}$ Mean: Median: Mode: S.D.

$\begin{array}{llll}2.88 & 3.14 & 3.10 & 1.38\end{array}$

$\begin{array}{rrrrrrr}\%< & 5 & 16 & 25 & 75 & 84 & 95\end{array}$

Size $\quad \begin{array}{llllll}1.35 & 2.51 & 2.72 & 3.65 & 4.53 & 7.10\end{array}$

$\%$ Gravel Sand Silt Clay $\begin{array}{llll}0.00 & 81.04 & 16.75 & 2.21\end{array}$

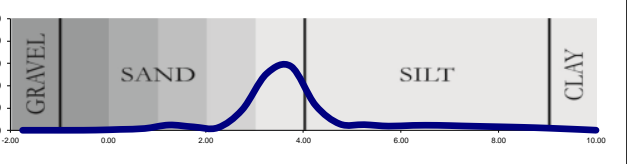


Additional Samples Class midpoints Class limits

Ms

Frequency \%

Cumulative \%

RRoad_Tm_30.\$ls

Frequency $\%$

Cumulative \%

RRoad_Tm_29.\$1s

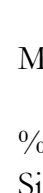

$\begin{array}{rrrrrrr}0 & 0 & 0 & 0 & 0 & 0 & 0 \\ 0 & 0 & 0 & 0 & 0 & 0 & 0 \\ \text { Mean: } & & \text { Median: } & \text { Mode: } & & \text { S.D. } \\ 5.93 & & 6.58 & & 6.06 & & 1.59 \\ \%< & 5 & 16 & 25 & 75 & 84 & 95 \\ \text { ize } & 4.37 & 5.06 & 5.51 & 7.91 & 8.45 & 9.24\end{array}$

\section{Cm-Sand}

Frequency \%

Cumulative \%

Oyster_HnearO_02.\$ls

\begin{tabular}{rrrrrrr}
0 & 0 & 0 & 0 & 0 & 0 & 0 \\
0 & 0 & 0 & 0 & 0 & 0 & 0 \\
Mean: & \multicolumn{2}{r}{ Median: } & Mode: & & S.D. \\
4.06 & & 4.09 & & 3.78 & & 1.44 \\
$\%<$ & 5 & 16 & 25 & 75 & 84 & 95 \\
Size & 2.92 & 3.39 & 3.59 & 5.27 & 6.15 & 7.88
\end{tabular}

\section{Cm-Sand}

Frequency \%

Cumulative \%

Oyster_HnearO2_03.\$1s $\begin{array}{lllllllllllllllllllllllll}-1.75 & -1.25 & -0.75 & -0.25 & 0.25 & 0.75 & 1.25 & 1.75 & 2.25 & 2.75 & 3.25 & 3.75 & 4.25 & 4.75 & 5.25 & 5.75 & 6.25 & 6.75 & 7.25 & 7.75 & 8.25 & 8.75 & 9.25 & 9.75 & 10\end{array}$

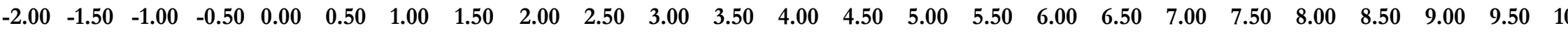

$$
\begin{array}{crrrrrr}
0 & 0 & 0 & 0 & 0 & 0 & 0 \\
0 & 0 & 0 & 0 & 0 & 0 & 0 \\
\text { Mean: } & \multicolumn{2}{r}{\text { Median: }} & \text { Mode: } & & \text { S.D. } \\
5.94 & & 6.52 & & 6.06 & & 1.53 \\
\%< & 5 & 16 & 25 & 75 & 84 & 95 \\
\text { Size } & 4.42 & 5.10 & 5.53 & 7.81 & 8.36 & 9.16
\end{array}
$$

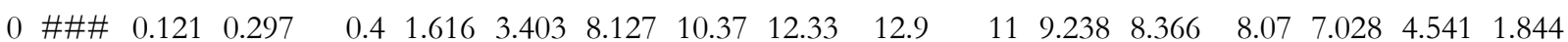

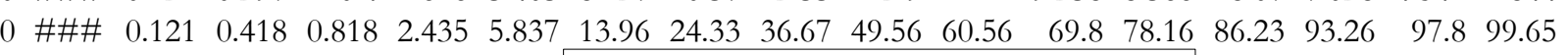

$\% \quad$ Gravel Sand Silt Clay $\begin{array}{llll}0.00 & 2.43 & 75.73 & 21.48\end{array}$

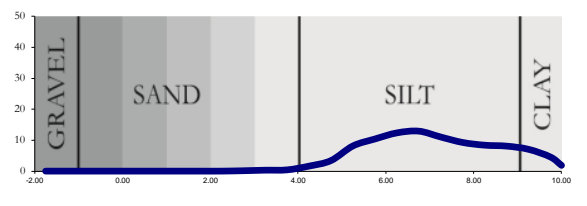

$\begin{array}{llllllllllllllllll}0 & \# \# \# & 0.104 & 0.376 & 0.461 & 1.675 & 3.778 & 8.387 & 9.963 & 11.44 & 12.1 & 10.56 & 9.105 & 8.476 & 8.363 & 7.434 & 4.971 & 2.214\end{array}$

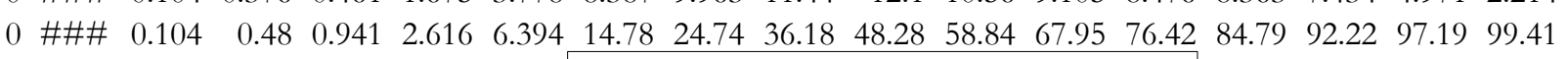

$\%$ Gravel Sand Silt Clay $\begin{array}{llll}0.00 & 2.62 & 73.81 & 22.98\end{array}$

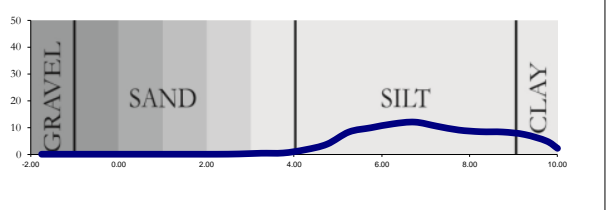

$\begin{array}{llllllllllllllllll}0 & 0.089 & 2.009 & 3.785 & 14.86 & 25.12 & 17.73 & 8.572 & 5.094 & 5.247 & 4.596 & 3.357 & 2.702 & 2.398 & 2.156 & 1.574 & 0.664 & 0.055\end{array}$

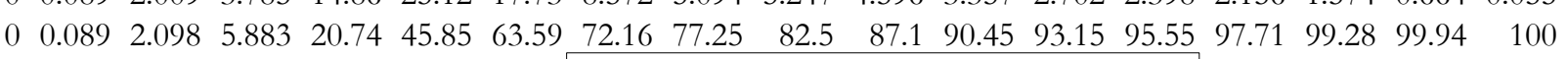

$\%$ Gravel Sand Silt Clay $\begin{array}{llll}0.00 & 45.85 & 49.70 & 4.45\end{array}$

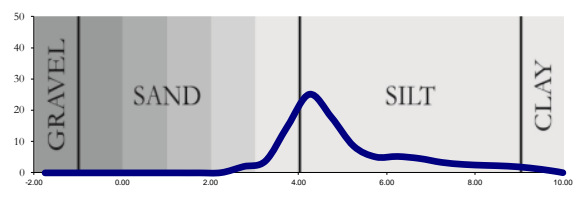

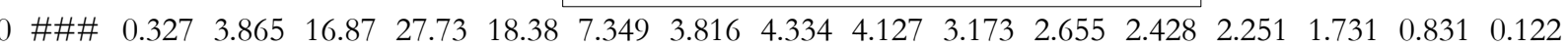

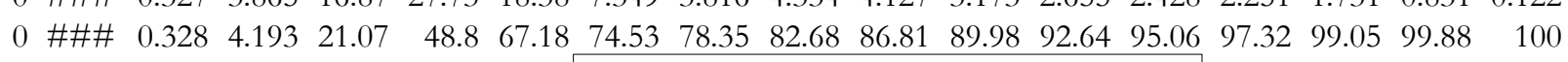

\% Gravel Sand Silt Clay $\begin{array}{llll}0.00 & 48.80 & 46.27 & 4.94\end{array}$

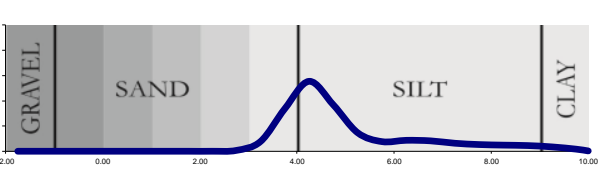


Appendix Four

\section{Tephra Analysis}




\section{Methods}

The methods described here are largely those previously developed for the project of Allan (2008).

\section{Sample preparation}

Volcanic glass was separated from bulk tephra samples and mounted in 'half moon' epoxy resin blocks for geochemical characterisation by EPMA (major elements) and LA-ICP-MS (trace elements). Samples were rinsed through a 33 $\mu \mathrm{m}$ nylon mesh to remove excess mud. This produced a residue of approximately $80-95 \%$ volcanic glass shards with the remainder comprising variable proportions of feldspar, mafic igneous minerals. The separated glass was then rinsed and decanted several times and left to dry at $50^{\circ} \mathrm{C}$ for $2-3$ days. The epoxy blocks were ground down using 400 - 4000 grit silicon carbide paper to expose the glass shards and then polished using $1 \mu \mathrm{m}$ liquid diamond suspension. A 25 $\mathrm{nm}$ carbon coating was then applied to each sample prior to major element characterisation by EPMA.

\section{Sample Analysis}

EPMA tephra analyses was made by John Creech, and were made using a JEOL JXA-8230 Superprobe equipped with 5 wavelength dispersive X-ray spectrometers. Glass shards were analysed with an accelerating potential of $15 \mathrm{kV}$, probe current of $8 \mathrm{nA}$ and a spot size of $20 \mu \mathrm{m}$, counting for $30 \mathrm{~s}$ and $15 \mathrm{~s}$ on peak and background, respectively. X-ray intensity calibrations were made against the MPI-DING rhyolite glass standard ATHO-G (Jochum et al., 2006). Approximately 15 shards were analysed from each tephra unit. Repeat analyses were made on ATHO-G and the rhyolite glass standard VG-568 (Jarosweich et $a l ., 1980)$ to estimate the internal precision. 


\section{References:}

Allan, A. S. (2008). An elemental and isotopic investigation of Quaternary silicic Taupo Volcanic Zone tephras from ODP Site 1123: chronostratigraphic and petrogenetic applications. (Unpublished M.Sc. thesis). Wellington: Victoria University of Wellington.

Jarosweich et al. (1980). Geostandards Newsletter, 4(1): 43-47

Jochum, K. P., et al. (2006), MPI-DING reference glasses for in situ microanalysis: New reference values for element concentrations and isotope ratios, Geochem. Geophys. Geosyst., 7, Q02008, doi:10.1029/2005GC001060. 


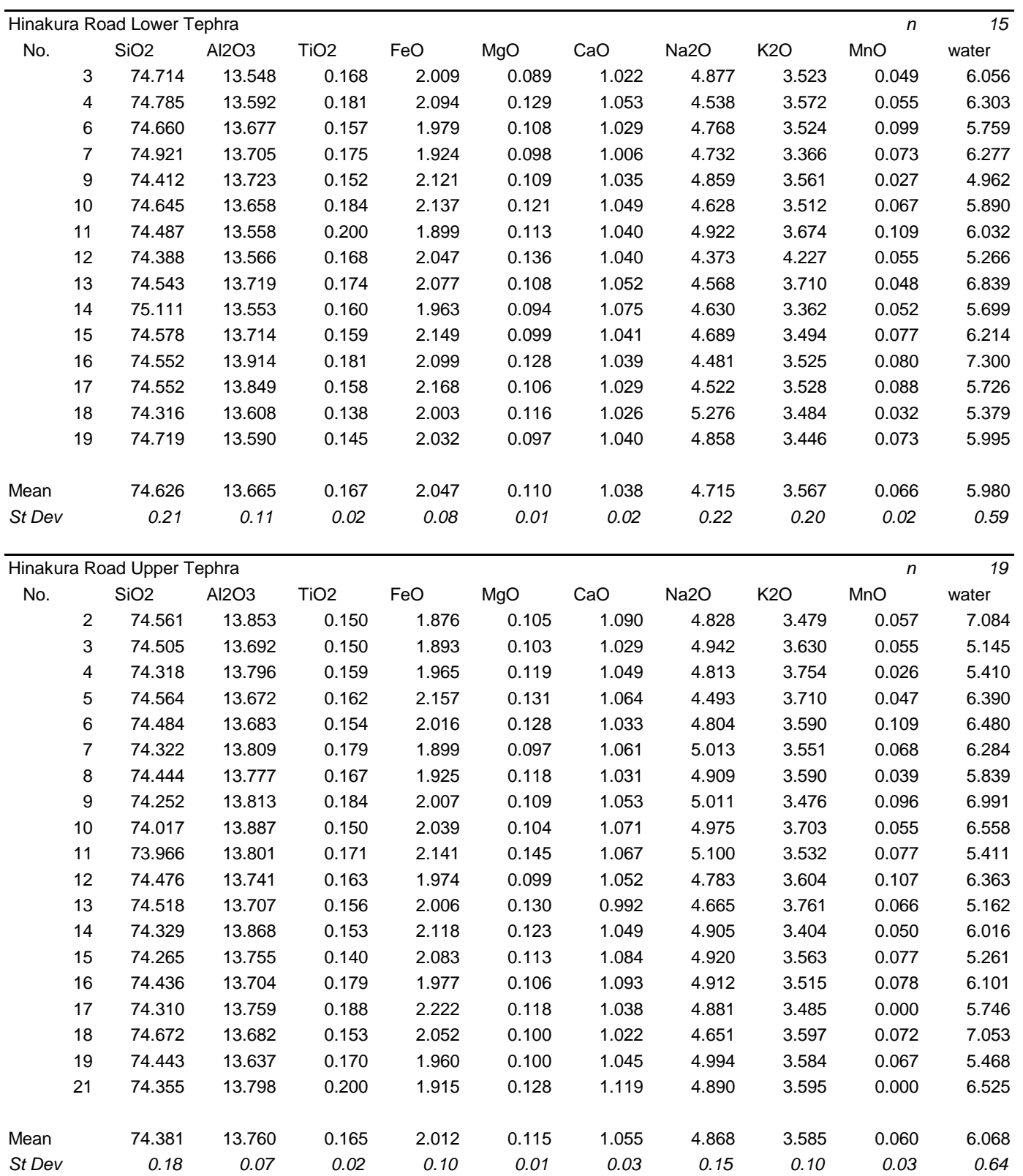




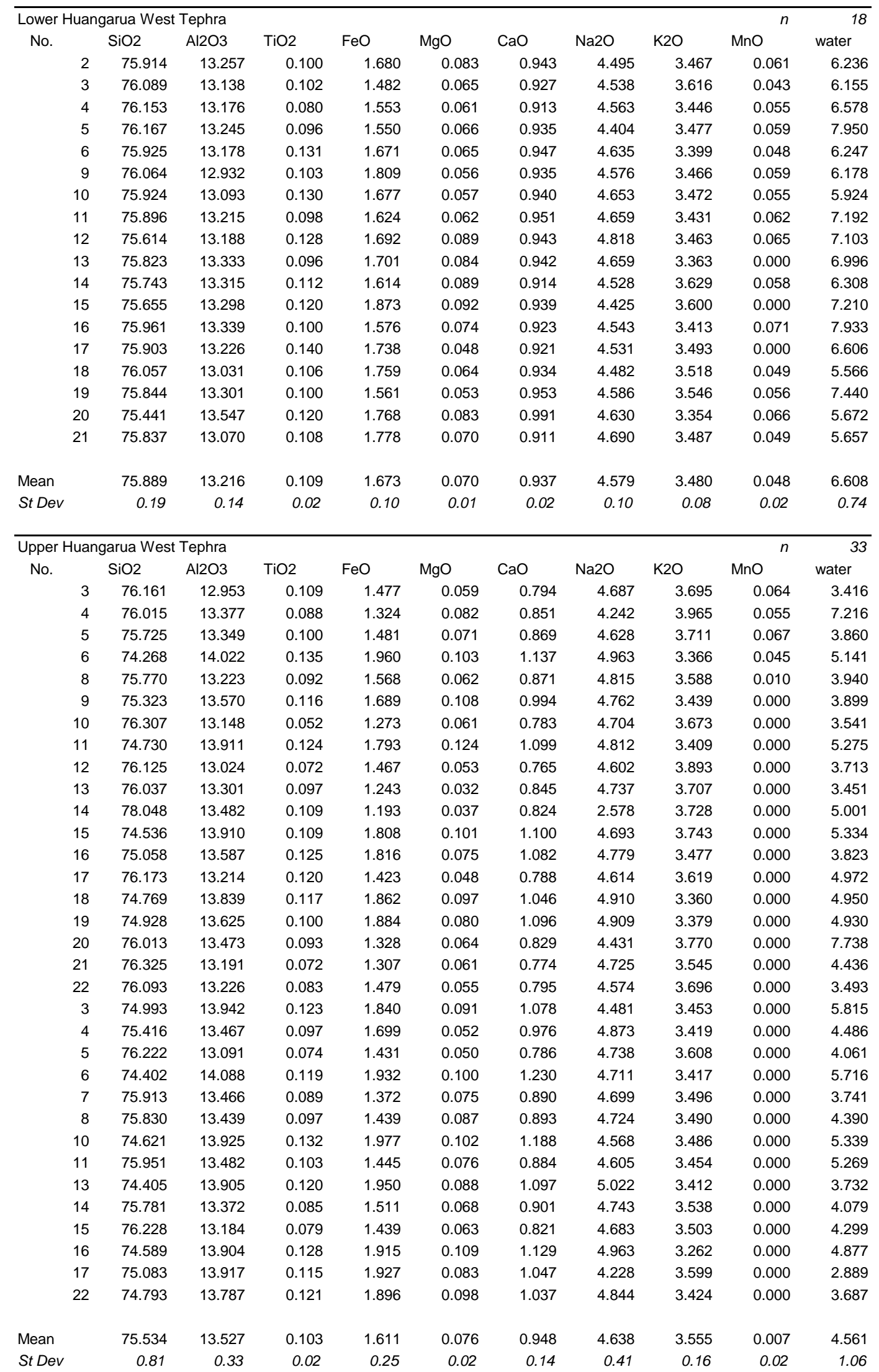




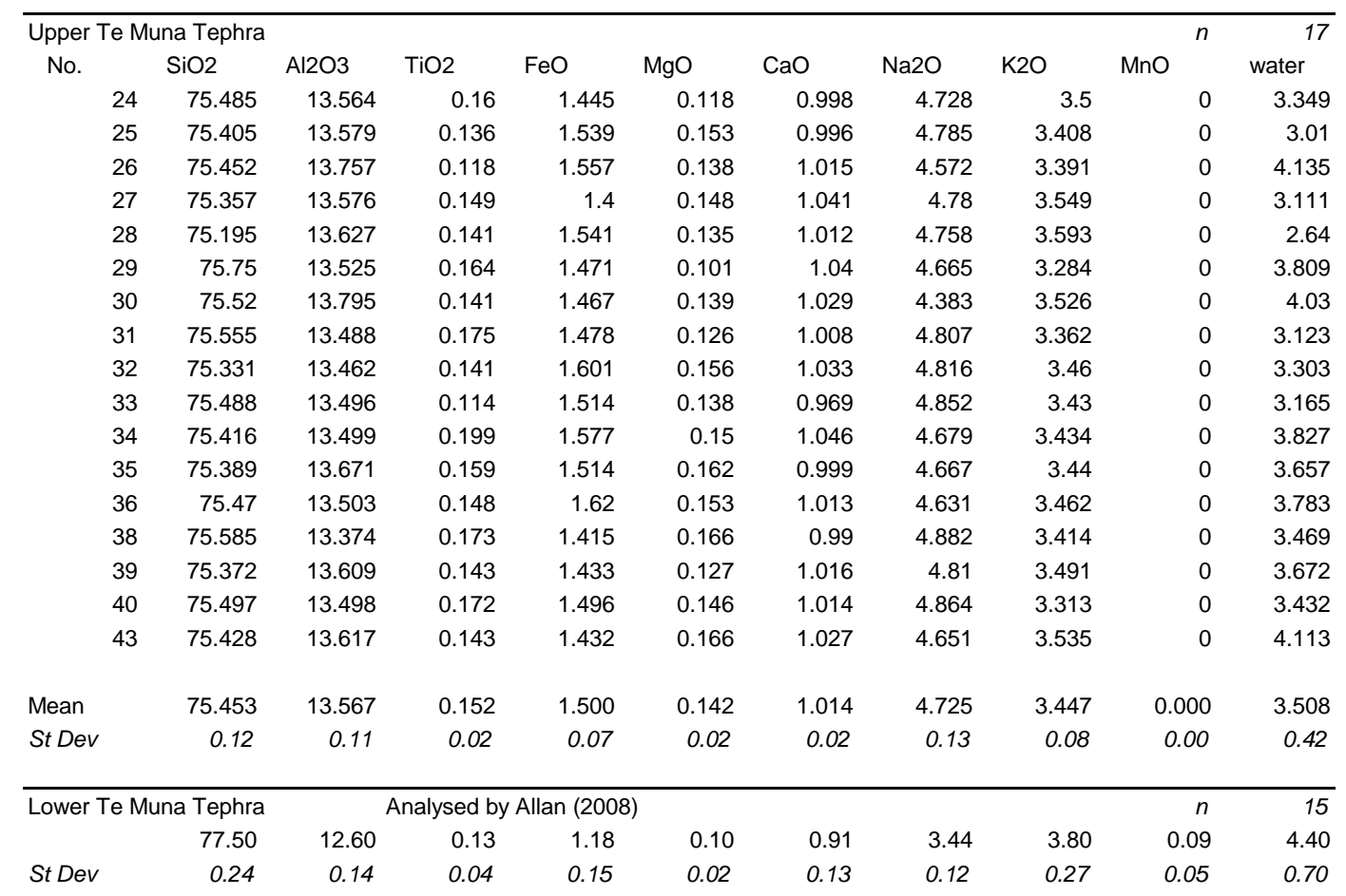


Appendix Five

\section{Location Conversion}


Ahiaruhe Formation Type Section

BP34 173478

Big Bend

Blue Rock Hautotara Section $(\mathrm{BH})$

Blue RockRace Section (BR)

Clay Creek Section (CC)

Duggan Ash

Gammate Structures in Te Muna Formation

Greycliffs Fm - Pukenui Limestone Contact (Fig 2.3)

Hinakura Road Lower Tephra

Hinakura Road Section (HR)

Hinakura Road Upper Tephra

Huangarua West Section (HW)

Huangarua-lower Tephra

Huangarua-upper Tephra

Lake Ferry

Lower Popes Head Tephra

Lower Te Muna Tephra

Oystershell Road

Popes Head

Proposed Pukenui Limestone Reference Section

Pukenui 2 Trig Station

Rataul outcrop (Chapter 2.3.2)

Ruakokoputuna Bridge Cliff Section (Rk)

Ruawaka

Ruawaka Section (Rw)

Te Muna Type Section

The Hautotara Bridge (Banana Bridge)

Type locality of the Pukenui Limestone

Upper Popes Head Tephra

Upper Te Muna Tephra

Waipuna
BQ34 079263

BQ33 026231

BQ33 026229

BQ33 014203

BQ33 028231

BQ34 089276

BQ34 072234

BQ34 144304

BQ34 145304

BQ34 144305

BQ34 094303

BQ34 089303

BQ34 094303

BQ32 793152

BQ34 145306

BQ34 089276

BQ34 120316

BQ34 141315

BQ34 075253

BQ33 035202

BQ34 097302

BQ33 038225

BQ34 085267

BQ34 086267

BQ34 089276

BQ34 072254

BQ34 070234

BQ34 145305

BQ34 089276
BQ33 025228
S27 273095

S27 179880

S27 126848

S27 126846

S27 114820

S27 128848

S27 189893

S27 172851

S27 244921

S27 245921

S27 244922

S27 194920

S27 189920

S27 194920

R28 893769

S27 245923

S27 189893

S27 220933

S27 241932

S27 175870

S27 135819

S27 197919

S27 138842

S27 185884

S27 186884

S27 189893

S27 172871

S27 170851

S27 245922

S27 189893

S27 125845 
Appendix Six

\section{Macrofossil Identification}


Bivalvia
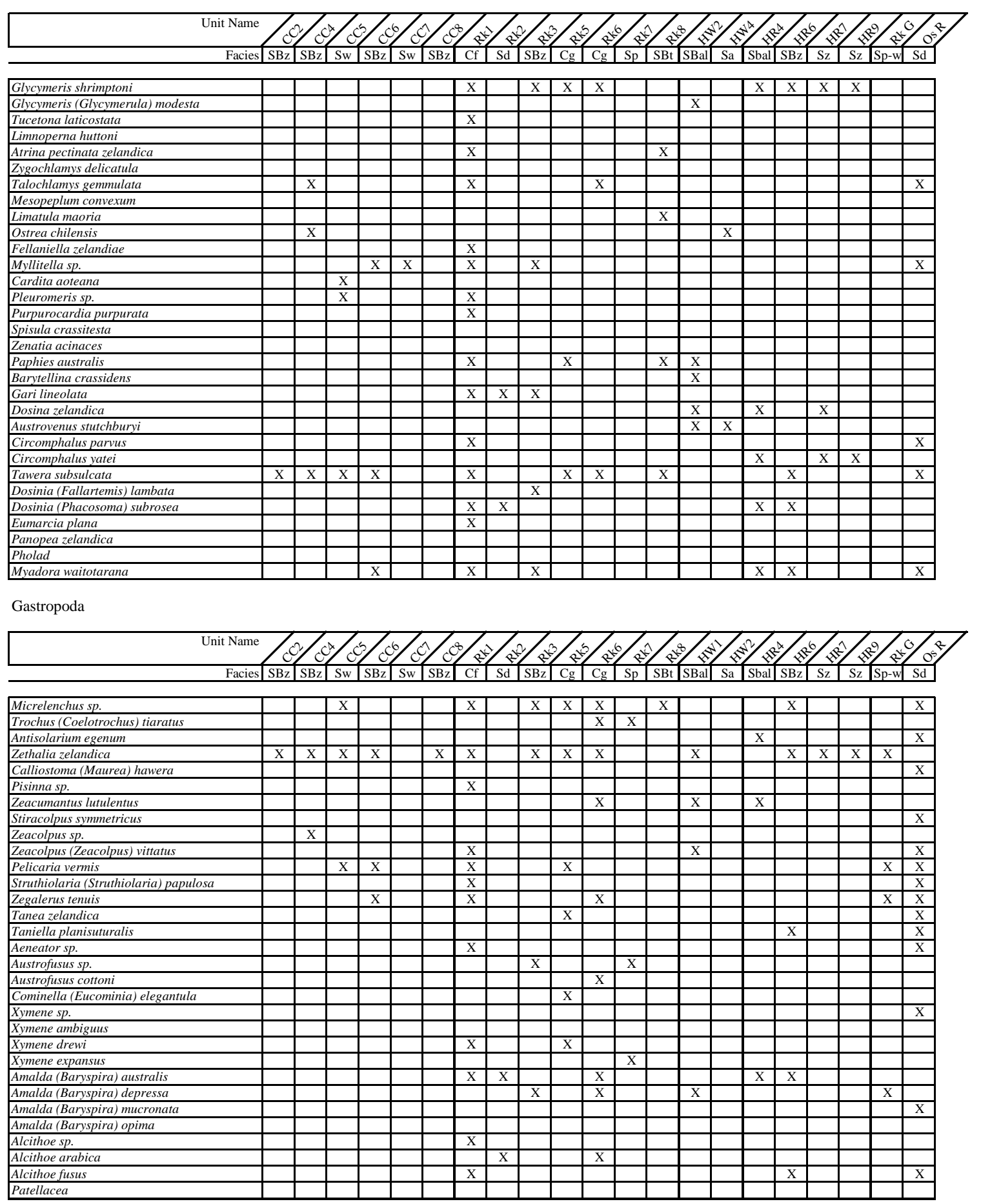

"Others"

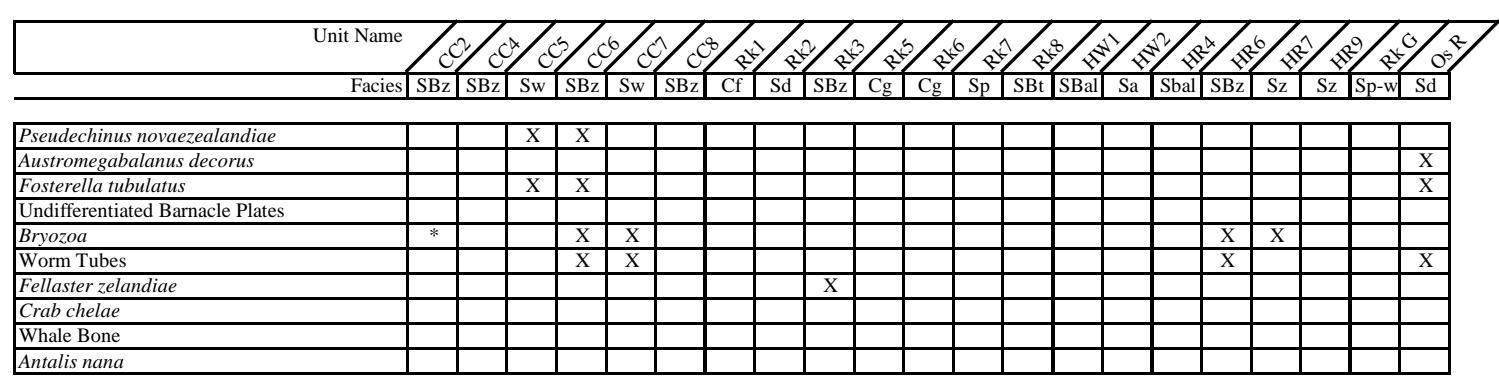

* Large Bryazoan colony (Figure A6.1) 


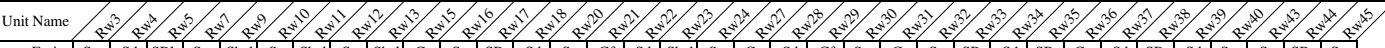

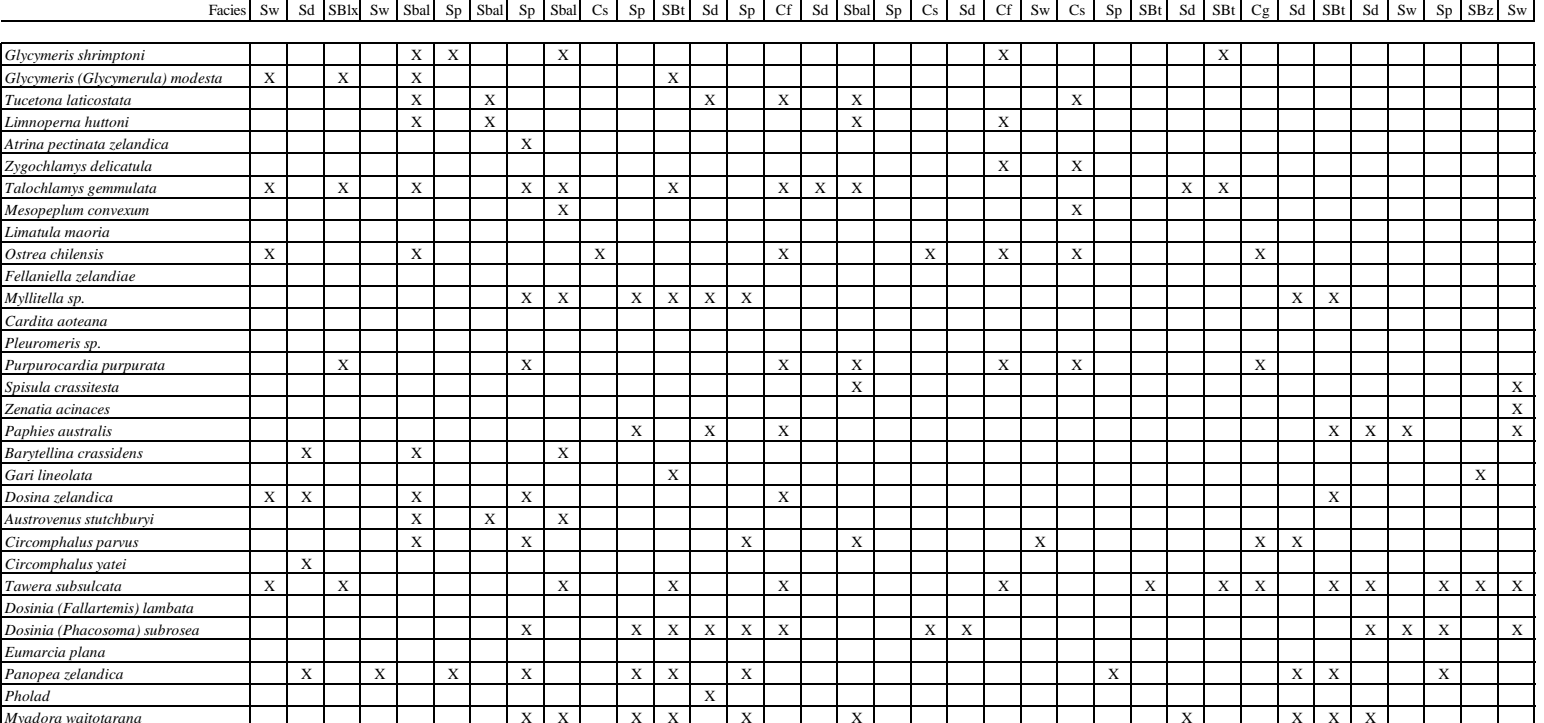

Pholad

Gastropoda

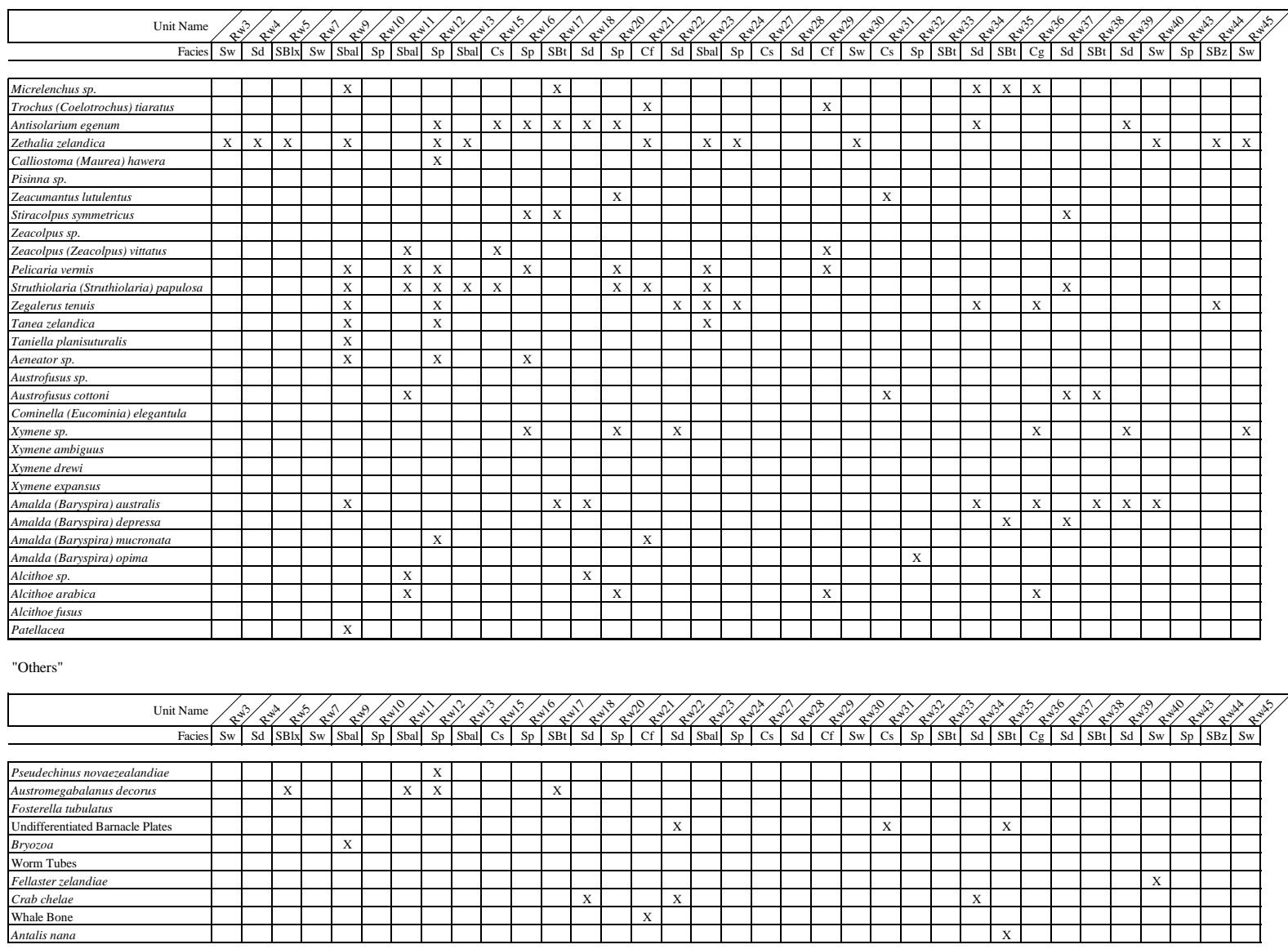

